\title{
SISTEMA FINANCEIRO, DESENVOLVIMENTO REGIONAL E ESTADO: A REGULAÇÃO JURÍDICA DO CRÉDITO FINANCEIRO
}

\begin{abstract}
Dissertação de Mestrado apresentada ao Departamento de Direito Econômico e Financeiro da Faculdade de Direito da Universidade de São Paulo (USP) como requisito parcial para obtenção do título de Mestre em Direito, sob a orientação do Prof. Dr. José Tadeu De Chiara.
\end{abstract}

Candidato: Ademir Antonio Pereira Júnior

\author{
Universidade de São Paulo \\ Faculdade de Direito \\ Departamento de Direito Econômico e Financeiro
}

São Paulo 
Nome: PEREIRA JÚNIOR, Ademir Antonio

Título: Sistema financeiro, desenvolvimento regional e Estado: a regulação jurídica do crédito financeiro

Dissertação de Mestrado apresentada ao Departamento de Direito Econômico e Financeiro da Faculdade de Direito da Universidade de São Paulo (USP) como requisito parcial para obtenção do título de Mestre em Direito, sob orientação do Prof. Dr. José Tadeu De Chiara. 
À Natália, sempre 


\section{AGRADECIMENTOS}

Inicialmente, agradeço ao meu orientador, Professor José Tadeu De Chiara, incondicional defensor da pesquisa acadêmica, que desde a época de minha graduação na Faculdade de Direito esteve presente como incentivador e guia de uma pesquisa que se propunha um tema complexo mas fascinante.

Necessário também agradecer aos Professores Gilberto Bercovici e Sebastião Tojal pelas importantes críticas apontadas durante o exame de qualificação, e aos Professores Calixto Salomão Filho, Diogo R. Coutinho e Emerson Fabiani, seja por discussões acerca de alguns dos temas abordados neste trabalho ou pela sempre pronta atenção e incitação à realização de trabalhos acadêmicos que insiram o raciocínio jurídico nas discussões acerca do desenvolvimento econômico.

Agradeço à Faculdade de Direito da USP e destaco sua importância central em meu desenvolvimento. Ao Largo São Francisco e aos amigos que aqui fiz, meus mais sinceros agradecimentos e o compromisso de lutar pela preservação de sua integridade enquanto instituição capaz de estimular o conhecimento.

Agradeço também aos colegas da Faculdade de Economia e Administração e da Faculdade de Filosofia, Letras e Ciências Humanas da USP, onde cursei matérias dos cursos de pós-graduação, pelos debates e reflexões inusitadas que certamente integram as ideias desenvolvidas neste trabalho. Sou grato também à Sociedade Brasileira de Direito Público pelo espaço para debates constitucionais impreteríveis, e aos colegas de escritório José Del Chiaro, Luiz Felipe R. Ramos e Mario André M. Cabral pelos debates sobre temas desta dissertação ou sobre diversas questões envolvendo Direito Econômico.

Agradeço profundamente aos meus pais, pelos desmedidos esforços em minha formação e por me apoiarem em tudo, e à toda minha família, que sempre me proporcionou conforto e alegria.

Mais do que agradecer, dedico este trabalho à Natália, presença fundamental na minha vida, pelo amor, carinho e compreensão.

Evidentemente, erros, omissões e problemas são de minha inteira e exclusiva responsabilidade. 


\section{RESUMO}

Assumindo a neutralidade dos fenômenos monetários sobre a economia real no longo prazo, a ortodoxia econômica sugere que a autoridade monetária (banco central) contribui para o desenvolvimento econômico unicamente por meio da garantia da estabilidade estabilidade de preços e da higidez financeira. Após as experiências de crises inflacionárias enfrentadas na década de 1980, bancos centrais de vários países passaram a apostar com maior vigor nessa concepção, eliminando um papel transformador ou uma atuação ativa dos bancos centrais no sentido de fomentar o desenvolvimento econômico e a redução de desigualdades. Essa escolha se deu em meio a um processo de "despolitização" que visava garantir aos bancos centrais maior autonomia, mediante reformas legais ou por meio de alterações informais nas relações entre os órgãos de governo. Esse processo evolui para a "apolitização" dos bancos centrais, baseado em alegado cientificismo de suas decisões.

Este trabalho tem como objetivo demonstrar que a alegada fundamentação científica da limitação da atuação das autoridades monetárias à garantia da estabilidade macroeconômica ignora (i) a existência de severas críticas teóricas às teorias sobre a neutralidade da moeda, (ii) os contextos específicos de cada país e as diferentes demandas de sua sociedade tendo em vista aspectos de desenvolvimento econômico e (iii) que a regulação monetária encerra decisões políticas, que devem ser pautadas pelo ordenamento jurídico dos países.

Dessa forma, embora se reconheça a relevância central da estabilidade macroeconômica, propõe-se um reexame dos objetivos da política monetária e da regulação bancária no contexto do desenvolvimento. Em razão da complexidade do tema e das diversas nuances, este trabalho tem como recorte material o desenvolvimento regional. Além disso, o mesmo recorte limita o foco ao caso brasileiro, em função das diferenças no contexto econômico e no ordenamento jurídico dos diversos países, para que o objeto do trabalho seja delimitado a aferir em que medida elementos de desenvolvimento regional devem integrar a racionalidade de intervenção do Estado brasileiro sobre o sistema bancário e, portanto, conformar a regulação monetária e sua supervisão e responsabilização (accountability).

Palavras-chave: moeda; desenvolvimento regional; regulação financeira; política monetária; banco central 


\begin{abstract}
Considering the neutrality of money in the long-run, the mainstream economics indicate that central banks' role in the economic development is limited to price and financial stability. After facing inflationary crisis during the decade of 1980, central banks from many countries started to vigorously support that conception, eliminating a changing role or an active performance of central banks in order to foster economic development and mitigate inequalities. That choice encompassed a process of "depoliticization", which aimed to ensure greater autonomy for central Banks, either through legal reforms or informal changes in the relationship among government agencies. Such process evolves to "apolitization" of central banks, based on alleged scientization of decisions.

The present dissertation intends to demonstrate that the alleged scientific foundation to limiting central banks`role to macroeconomic stability does not consider (i) a broad range of critics to the theories of neutrality of money, (ii) specific contexts of each country and the different demands of the societies considering elements related to economic development and (iii) monetary regulation encompasses politic decisions, which must be constrained by the legal arrangements of each country.

Thus, even though macroeconomic stability should be regarded as fundamental, we propose a reassessment of the goals of monetary policy and financial regulation in light of development issues. In reason of the complexity of the subject, the dissertation focuses on regional development aspects. Furthermore, considering the different economic atmospheres and legal regulations of the countries, we focus on the Brazilian case, so that the scope of the dissertation is limited to assess whether regional development issues should be incorporated by monetary policy and financial regulation in Brazil and, as a result, be part of the supervision and accountability of central banks.
\end{abstract}

Key-Words: money; regional development; financial regulation; monetary policy; central bank. 


\section{LISTA DE TABELAS}

TABELA I - EVOLUÇÃO DOS BANCOS CENTRAIS ANTES DE 1900 p. 45

TABELA II - EVOLUÇÃO DO NÚMERO DE BANCOS CENTRAIS p. 45

TABELA III - DIFERENÇAS ENTRE CENTRO E PERIFERIA NA TEORIA PÓS-KEYNESIANA p. 98

TABELA IV - EVOLUÇÃO DO CRÉDITO p. 109

TABELA V - CRÉDITO E PIB PRO REGIÕES p. 113

TABELA VI - CONCENTRAÇÃO DE CRÉDITO E ECONÔMICA

p. 114

\section{LISTA DE GRÁFICOS E MAPAS}

GRÁFICO I - COMPOSIÇÃO DO CRÉDITO BANCÁRIO NO BRASIL p. 106 GRÁFICO II - PADRÃO DE FINANCIAMENTO DOS IMVESTIMENTOS NA INDÚSTRIA E NA INFRAESTRUTURA (20042009)

GRÁFICO III - CARTEIRA DOS BANCOS: CRÉDITO SUPERIORES A p. 108 5 ANOS

MAPA 1 - PARTICIPAÇÃO NO PIB POR ESTADO

p. 116

MAPA 2 - PARTICIPAÇÃO NO CRÉDITO POR ESTADO

p. 116 


\section{SUMÁRIO}

INTRODUÇÃO

p. 10

1. POLÍTICA ECONÔMICA, DESENVOLVIMENTO E p. 14 MOEDA

1.1. Definindo a estrutura operativa da política econômica: direito como objetivo e ferramenta e a economia como instrumento de análise fática

1.2. A questão regional como objeto das políticas econômicas do p. 25 Estado: a justificativa jurídica e econômica

1.3. Autonomia, cientificização e accountability: a intervenção sobre o sistema financeiro e a necessidade de ponderação de aspectos de desenvolvimento regional

2. MOEDA, SISTEMA FINANCEIRO $\quad$ E $\quad$ p. 34 DESENVOLVIMENTO: O PAPEL DO CRÉDITO FINANCEIRO

2.1. Autoridade monetária e controle da liquidez

2.2. Formação dos bancos centrais e a assunção do papel de autoridade monetária

2.3. O controle da liquidez pelos bancos centrais: política monetária e p. 50 Regulação

2.4. Intervenção sobre a atividade bancária: o coro pela limitação

2.5. Autonomia e cientifização: da despolitização à apolitização e o problema da accountability

2.6. Autoridade monetária e desenvolvimento: estabilidade de preços e p. 73 financeira como únicos papéis?

3. A QUESTÃO ECONÔMICA E O CONTEXTO NACIONAL: DESENVOLVIMENTO REGIONAL E p. 80 SISTEMA BANCÁRIO NO BRASIL

3.1. Ortodoxia: a moeda como elemento neutro no processo de p. 82 desenvolvimento

3.2. Sistema financeiro e desenvolvimento regional: a visão pós- p. 84 
keynesiana

3.2.1. A economia monetária de produção $\quad$ p. 85

$\begin{array}{ll}\text { 3.2.2. A teoria da preferência pela liquidez } & \text { p. } 88\end{array}$

3.2.3. A preferência pela liquidez como uma teoria de precificação p. 92 de ativos

3.3. Preferência pela liquidez e as diferentes instituições e ambientes p. 96 regionais

3.3.1. O papel do sistema financeiro na trajetória desigual de p. 96 desenvolvimento regional

3.4. A experiência brasileira: desenvolvimento desigual entre regiões e a p. 105 concentração do sistema financeiro

3.5. A regulação estatal como elemento exógeno e capaz de reverter a p. 117 lógica da desigualdade

4. A QUESTÃO JURÍDICA: AUTORIDADE MONETÁRIA E ORDEM JURÍDICA NO BRASIL

4.1. Autoridade monetária: a quem cabe e quais as atribuições?

p. 125

4.2. Constituição, desenvolvimento regional e autoridade monetária

p. 130

4.3. Entre autonomia (de fato) e cientificização: a superação da

p. 146 dogmática jurídica

4.4. Insulamento da burocracia do BCB e a abstenção (ou ratificação) p. 155 pelos Poderes da República: a força do discurso da estabilidade

4.4.1. Conjuntura, lei complementar e a consolidação da autonomia econômica das autoridades monetárias

4.4.2. A organização da burocracia: em prol da autonomia política

p. 170 e do cientificismo

CONCLUSÃO

p. 178

BILIOGRAFIA

p. 181 


\section{INTRODUÇÃO}

A limitação da intervenção do Estado sobre o sistema bancário tem sido preconizada amplamente por teorias econômicas qualificadas como ortodoxas e que pretendem o status de quase consensuais entre os teóricos. Assumindo a neutralidade dos fenômenos monetários sobre a economia real no longo prazo, essa ortodoxia sugere que a política monetária e a regulação bancária (denominadas em conjunto de "regulação monetária") devem ter como objetivos centrais - e, possivelmente, exclusivos - a estabilidade de preços e a higidez financeira.

Autoridades monetárias de vários países passaram a apostar com maior vigor nessa concepção após as experiências de crises inflacionárias enfrentadas na década de 1980. Nesse sentido, a "receita" de melhores práticas internacionais indica a estabilidade macroeconômica como o principal objetivo da atuação do Estado sobre o setor bancário. Dentro dessa concepção, a autoridade monetária contribui para o desenvolvimento econômico unicamente por meio da garantia da estabilidade. À autoridade monetária não é conferido um papel transformador ou uma atuação ativa no sentido de fomentar o desenvolvimento econômico e a redução de desigualdades.

Os bancos centrais passaram então por um processo de "despolitização", realizada mediante reformas legais ou por meio de alterações informais nas relações entre os órgãos de governo para garantir aos bancos centrais maior autonomia. O discurso da estabilidade encontra-se diretamente relacionado à definição dos limites da autonomia das autoridades monetária, que evoluem para um processo de "apolitização", baseado em alegado cientificismo de suas decisões.

Este trabalho tem como objetivo demonstrar que a alegada fundamentação científica da limitação da atuação das autoridades monetárias à garantia da estabilidade macroeconômica ignora (i) a existência de severas críticas teóricas à teoria quantitativista da moeda, (ii) os contextos específicos de cada país e as diferentes demandas de sua sociedade tendo em vista aspectos de desenvolvimento econômico e (iii) o ordenamento jurídico dos países, que encerram decisões políticas pretéritas que devem ser sopesadas. 
Por essas razões, os objetivos da política monetária e da regulação bancárias e seus parâmetros de avaliação devem ser revisitadas. Em razão da complexidade do tema e das diversas nuances a serem ponderadas, este trabalho centra-se em um dos aspectos do desenvolvimento econômico: o desenvolvimento regional. Além disso, dadas as diferenças no contexto econômico e no ordenamento jurídico dos diversos países, a análise tem como objeto o caso brasileiro, em que o desenvolvimento regional encontra status constitucional. Faz-se necessário então analisar em que medida elementos de desenvolvimento regional devem integrar a racionalidade de intervenção do Estado brasileiro sobre o sistema bancário e, portanto, conformar a política monetária e a regulação bancária.

No primeiro capítulo, procura-se evidenciar que a formulação das políticas econômicas que visam o desenvolvimento devem considerar conjuntamente os objetivos e ferramentas definidas pelo direito e utilizar a teoria econômica como subsídio para análise das questões fáticas. A questão regional emerge assim como um objeto das políticas econômicas do Estado brasileiro, especialmente da política econômica relativa à regulação monetária, considerando-se elementos econômicos e jurídicos.

O segundo capítulo investiga a importância do setor bancário e do crédito financeiro para o desenvolvimento econômico e aponta a evolução e papel assumido pelas autoridades monetárias nos últimos anos. Nesse capítulo, a ortodoxia econômica e o contexto sobre o qual ela se desenvolveu são analisados, para que os fenômenos da "despolitização" e "apolitização" das autoridades monetárias sejam identificados e, na sequência, criticados. A crítica desenhada no final do capítulo 2 é detalhada nos capítulos 3 e 4 com foco especificamente no desenvolvimento regional.

O crédito financeiro (originado na atividade de intermediação financeira) assume um papel central no crescimento das atividades produtivas, pois cria disponibilidade de recursos para que os investimentos produtivos sejam realizados. O capítulo 3 procura demonstrar que a distribuição desses recursos financeiros entre regiões altera as condições e patamares de desenvolvimento inter-regional, conforme discute larga literatura econômica que debate os impactos de sistema bancário sobre as regiões do país. 
Segundo autores caracterizados como pós-keynesianos, existem elementos nas escolhas e performance dos bancos - instituições capazes de influenciar a disponibilidade e alocação de recursos financeiros - que levam a patamares de desenvolvimento desigual entre regiões. Em outras palavras, o livre jogo do mercado leva, necessariamente, à perpetuação e extensão da desigualdade regional. Os postulados teóricos têm sua aplicabilidade demonstrada ao caso brasileiro, em que o comportamento mais racional dos agentes, determinado por sua preferência pela liquidez, leva à concentração regional do crédito nas regiões mais desenvolvidas, especialmente a região Sudeste e, com maior ênfase, o Estado de São Paulo, "drenando" recursos das regiões menos desenvolvidas. Nesse sentido, seriam necessárias políticas públicas de intervenção sobre o sistema financeiro a fim de atenuar ou reverter essa tendência.

Portanto, tem-se uma questão fática exposta em termos econômicos: em um país com contrastes regionais, o sistema financeiro tende, num cenário de livre jogo do mercado e em que os agentes expressam livremente sua preferência pela liquidez, a intensificar essas desigualdades mediante a concentração do crédito financeiro nas regiões mais desenvolvidas. De outro lado, há uma norma constitucional que estabelece como objetivo da República garantir o desenvolvimento nacional e reduzir as desigualdades sociais e regionais (artigo $3^{\circ}$ da Constituição Federal). Esse é o ponto de partida do capítulo 4, que evidencia que tanto a Constituição Federal quanto a Lei 4.594/64 exigem verdadeira atuação transformadora das autoridades monetárias.

O capítulo 4 é essencialmente dedicado a demonstrar que a Constituição de 1988 é verdadeira Constituição Econômica, estabelecendo um programa de alterações sócioeconômicas em que o sistema financeiro é elemento central. Nesse sentido, metas são estabelecidas para as autoridades monetárias, e elas devem integrar a racionalidade de sua ação e fazer parte da accountability substantiva das autoridades monetárias.

A despeito da regulamentação jurídica, nota-se nítida priorização da estabilidade de preços e higidez financeira pelas autoridades monetárias no Brasil, transformando a Constituição Econômica em verdadeira constituição liberal. Essa priorização é baseada na ortodoxia econômica e no temor ainda causado pela crise inflacionária enfrentada pelo 
país, o que vem garantindo autonomia de fato às autoridades monetárias, conforme atos dos Poderes Executivo e Legislativo examinados através da jurisprudência do Supremo Tribunal Federal apontam. Esse capítulo é seguido pela conclusão do trabalho. 


\section{POLÍTICA ECONÔMICA, DESENVOLVIMENTO E MOEDA}

O conjunto de ações do Estado sobre os mercados constitui o que se convencionou denominar de política econômica. Pautado pelas premissas e bases da teoria econômica e do ordenamento jurídico, o Estado emana decisões políticas sobre os instrumentos a serem utilizados na consecução dos fins desejados.

Apontar genericamente o desenvolvimento econômico como objetivo da política econômica dos Estados seria declarar algo quase impassível de questionamento. Mais do que isso, é fora de questão que, a partir do século XX, as políticas econômicas têm sempre buscado duas metas principais: o crescimento das atividades produtivas mediante o aproveitamento eficiente de recursos e a redução das desigualdades entre os cidadãos. É claramente difícil imaginar um governo que conseguisse manter-se no Poder, ainda que pela força, com uma política econômica declaradamente voltada à perpetuação de desigualdades e à estagnação econômica.

Assim, o rol de objetivos dos Estados tem uma base principiológica comum que tem se repetido pelos diversos governos que se estabelecem. No entanto, ainda que apontar as metas gerais das políticas econômicas seja uma tarefa simples em razão do consenso sobre o tema, a divergência sobre os meios para se alcançar essas metas e as nuances do significado e alcance de cada um desses objetivos têm sido objeto de amplo debate e divergência ${ }^{1}$. É nesse sentido que a política econômica, a despeito de uma base comum presente numa opção de Estado, sujeita-se às escolhas de governo e pode sofrer alterações importantes conforme governos distintos se alternem.

As teorias sobre desenvolvimento econômico refletem essa divergência sobre as estruturas operativas adequadas para as políticas econômicas. Existem entendimentos diversos sobre os significados do desenvolvimento e, especialmente, sobre as alternativas e os meios para sua concretização.

\footnotetext{
${ }^{1}$ Nesse sentido, ver George Stigler, The Goals of Economic Policy, in The Journal of Business vol. XXXI (1958), pp. 176-196.
} 
As primeiras escolas de pensamento efetivamente estruturadas para o estudo das relações de causalidade do desenvolvimento econômico das nações surgiram apenas após a Segunda Guerra Mundial e foram nitidamente dominadas pelo pensamento econômico, cujos métodos e racionalidades ditaram a conformação dos trabalhos teóricos realizados. Essas teorias, cuja ampla influência as alçou à posição de ortodoxia no campo das reflexões sobre desenvolvimento econômico, estiveram focadas no exame dos elementos que aumentavam a eficiência nos mercados e levavam, por consequência, ao crescimento das atividades produtivas. Dessa forma, crescimento econômico seria sinônimo de desenvolvimento econômico.

Focadas no crescimento econômico, tais análise assumiam a premissa de que o crescimento das atividades produtivas geraria maior riqueza que, por sua vez, acabaria incrementando gradualmente as condições de vida de toda a população de um país. Portanto, os economistas acreditavam que deveriam concentrar-se em identificar estratégias que proporcionassem o crescimento econômico dos países ${ }^{2}$, pois, uma vez implementadas, elas levariam a um incremento da riqueza e a uma "natural" melhoria das condições de vida de toda a população. Em outras palavras, os benefícios do crescimento acabariam refletindo positivamente sobre os mais pobres, gerando redução dos níveis de pobreza $^{3}$.

Enquanto crescimento econômico, o desenvolvimento diz respeito não só ao crescimento gradativo das atividades produtivas, com manutenção de um estado de equilíbrio, mas também, como apontou Schumpeter, ao crescimento da produção em razão das alterações nos padrões de consumo e produção, em razão de inovações que modifiquem as combinações dos bens e gerem novos estados de equilíbrio ${ }^{4}$.

Schumpeter insere o elemento dinâmico na análise e confere a esse elemento papel central no processo de desenvolvimento. Nesse sentido, a terminologia adotada por Schumpeter distingue claramente desenvolvimento (inovação) de crescimento (alterações

\footnotetext{
2 "We sense here the big payoff, the possibility of change with extraordinarily beneficial consequences, if one oinly knew the exact combination of circumstances that derives economic growth" (Debraj Ray, Development Economics, Princeton: Princeton University, 1998, p. 47).

${ }^{3}$ Essa literatura é questionada em Hulya Dagdeviren, Rolph van der Hoeven e John Weeks, Redistribution Does Matter, WIDER Discussion Paper n. 5, UNU-WIDER, 2002.

${ }^{4}$ Cf. Joseph A. Schumpeter, Teoria do desenvolvimento econômico, Fundo de Cultura: Rio de Janeiro, 1961.
} 
graduais e esperadas no fluxo circulatório da economia). No entanto, é inegável que o foco de Schumpeter está no crescimento das atividades produtivas: o desenvolvimento entendido como geração de novas combinações mais eficientes (inovação) resultaria, ao final, em crescimento das atividades produtivas. Essa faceta relacionada à inovação tem ganhado uma dimensão ainda mais expressiva nas últimas décadas, em que a dinâmica de competição por inovações tem, muitas vezes, substituído a dinâmica de concorrência estática pautada essencialmente em preços ${ }^{5}$.

Nesse contexto, o modelo de capitalismo fordista, que predominou soberanamente até as últimas décadas do século XX, convive atualmente com um modelo de produção baseado no conhecimento e na inovação. O capitalismo fordista tem seu ápice na economia norte-americana entre as décadas de 1930 e 1970, baseado em altos investimentos privados que procuravam organizar a atividade empresarial mediante a internalização da produção em grandes corporações. A produção industrial procurava atender a uma demanda massificada, gerando uma produção em larga escala de produtos intensamente padronizados. O consumo de massa gerava a necessidade de expansão da produção, favorecendo as grandes corporações e suas economias de escala. De outro lado, a demanda em expansão atenuava os impactos da substantiva concorrência enfrentada sobre os resultados financeiros das empresas e suas capacidades de reinvestimento.

Na década de 1980, no entanto, verificou-se uma crise no capitalismo fordista, em função da saturação da demanda dos mercados norte-americano e europeu por bens duráveis produzidos em massa. Afinal, a padronização dos produtos esgotava suas utilidades, de modo a reduzir as necessidades das pessoas pelos bens produzidos. Essa retração na demanda resultou em substantiva ociosidade dos meios de produção e avanço dos níveis de desemprego, gerando um processo cumulativo de redução da produção e queda do nível de consumo. Esse processo foi acompanhado por problemas de liquidez e inflação na economia mundial, que terminaram por exigir a ascensão de um novo padrão produtivo ${ }^{6}$.

\footnotetext{
5 . Joseph A. Schumpeter, Teoria do desenvolvimento econômico, op. cit., pp. 140 e ss.

${ }^{6}$ A evolução das telecomunicações e dos transportes permitiu uma rápida expansão do comércio mundial e a reestruturação do sistema financeiro internacional, que resultou na total mobilidade e desmaterialização da moeda. Uma síntese desse contexto e das alterações na formulação do Direito podem ser encontradas em José Eduardo Faria, O Direito na economia globalizada, São Paulo: Malheiros, 2004, pp. 75-80.
} 
Como resposta à crise, as grandes corporações reorganizaram suas estruturas decisórias e produtivas, realizando uma série de fusões e associações, de modo a alcançar a redução dos custos organizacionais, a diluição dos riscos existentes na cadeia produtiva e maior competitividade internacional.

Essa resposta compreendeu ainda uma alteração na dinâmica da competição entre as empresas, que passaram a investir na diferenciação de produtos e criação de novas utilidades e experiências de consumo. Emergiu assim um novo padrão pautado no conhecimento, que concentra em seu núcleo a noção de inovação: os consumidores necessitam de novos incentivos à realização de compras no mercado. O padrão fordista levou a um número imenso de lares no mundo um aparelho de televisão, de modo que poucos ainda necessitavam comprar televisores. O lançamento de um produto com as mesmas funções mas diferente, ou seja, capaz de oferecer nova utilidade ao consumidor, termina por levar os indivíduos novamente ao mercado: no exemplo dos televisores, o lançamento da High Definition Television constitui essa diferenciação.

A diferenciação é um conceito central para o modelo de produção capitalista baseado na inovação. Ela evidencia que inovar não é somente desenvolver alta tecnologia, mas sim apresentar algo que se diversifique, crie nova utilidade, para que possa interessar ao mercado.

Cumpre ressaltar neste ponto que a produção em massa não deixa de existir. Ao contrário, permanece como padrão quantitativamente predominante de produção, mas além de passar a conviver com a produção pautada pela diferenciação, requer ajustes estruturais, que permitam a redução de custos em face à concorrência internacional. Nesse sentido, o crescimento das atividades produtivas depende da consolidação e aprimoramento da produção baseada no modelo fordista (desenvolvimento de novos processos produtivos) e da diversificação não só de produtos, mas também das atividades desenvolvidas ${ }^{7}$.

\footnotetext{
${ }^{7}$ Teóricos da segunda metade do século XX, inspirados pela obra de David Ricardo, sugeriam que os países em desenvolvimento deveriam concentrar seus esforços produtivos sobre atividades em que apresentassem vantagens comparativas, alcançando assim elevado grau de especialização. Essa análise, no entanto, vem sendo contrariada por teóricos e pesquisas empíricas que evidenciam a necessidade de diversificação das atividades produtivas, alcançando o domínio sobre uma série de atividades para somente em momento posterior optar por elevado grau de especialização. Para uma crítica à especialização regional como modo de alcançar o desenvolvimento, exposta como traço marcante da dependência estabelecida e perpetuada entre os países desenvolvidos e subdesenvolvidos, ver Celso Furtado, Criatividade e dependência na civilização
} 
A diversificação das atividades produtivas mediante o desenvolvimento de novos setores produtivos encontra obstáculos que dificultam sua realização: externalidades informacionais e organizacionais ${ }^{8}$.

Primeiramente, os empresários devem descobrir que novas atividades e produtos podem ser produzidos a custos reduzidos no país e gerar, por consequência, remuneração adequada a seu investimento. Essa atividade inovadora, que compreende tanto a descoberta de novas tecnologias quanto a produção de bens já produzidos internacionalmente, mas que não são produzidos no país $(\text { catch-up })^{9}$, apresenta custos e riscos provenientes da dificuldade em se definir quais atividades serão bem sucedidas (externalidade informacional).

De outro lado, o desenvolvimento de uma atividade inovadora exige a realização de investimentos simultâneos também em outras atividades, de modo a se constituir uma cadeia produtiva capaz de gerar e absorver a nova atividade. Essa falha organizacional (ou de coordenação) resulta na incerteza do empresário acerca da confluência dos investimentos necessários, de modo a inviabilizar seu investimento em inovação.

Dessa forma, a inovação depende em grande parte da superação ou mitigação dessas externalidades, o que exige a assunção de elevado risco por aqueles que se propuserem a inovar. Por isso, esforços de inovação recebem em geral diversos incentivos em formas de políticas econômicas estruturadas para esse fim ou que se ajustem a ele dentre elas, a mais comumente lembrada é a política industrial -, podendo relacionar-se a incentivos fiscais, atuação de empresas estatais ou investimentos estatais nas atividades privadas (bancos de desenvolvimento, venture capital), proteção de investimentos (como leis para proteção de propriedade material e imaterial) e outras.

industrial, Rio de Janeiro: Paz e Terra, 1978, pp. 76 e ss. Para uma síntese dos principais argumentos teóricos envolvendo a disputa entre diversificação e especialização no desenvolvimento econômico do país, bem como uma análise empírica que procura evidenciar que a organização das atividades econômicas de um país deve passar por um estágio de diversificação para somente em momento posterior procurar a especialização, ver Jean Imbs e Romain Wacziarg, Stages of Diversification, in American Economic Review 93 (2003), pp. 63-86.

${ }^{8}$ A exposição aqui baseia-se amplamente em Dani Rodrik, Industrial Policy for Twenty-First Century, disponível on line in http://ksghome.harvard.edu/ drodrik/papers.html.

${ }^{9}$ Dani Rodrik refere-se à descoberta de bens que são produzidos internacionalmente e que ainda não o são no âmbito nacional, mas que podem ser produzidos localmente a custos baixos, como um processo de autodescoberta ("self discovery"). 
A ênfase exclusiva ao crescimento econômico - por meio de inovações ou por ganhos de eficiência estática - passou a ser questionada à medida que em diversos países o mesmo não foi acompanhado pela redução da desigualdade ou, no mínimo, pela redução da pobreza ${ }^{10}$.

As experiências nas décadas de 1970 e 1980 levaram ao reconhecimento, a partir de meados da década de 1990, de que o crescimento econômico não implica necessariamente desenvolvimento. $\mathrm{O}$ crescimento econômico pode ser observado sem que sejam encontrados reflexos positivos nas diversas camadas da sociedade ou, ainda pior, poderia ser acompanhado pelo agravamento das condições de pobreza e desigualdade.

Como resultado, os teóricos passaram a notar que o desenvolvimento econômico de uma sociedade não equivale ao mero crescimento econômico, ainda que esse aspecto seja um de seus vetores fundamentais. Em outras palavras, a discussão sobre o desenvolvimento tornou-se mais complexa, passando a compreender preocupações não apenas com o incremento da eficiência dos fatores produtivos. Esse vetor permaneceu como fundamental, no entanto o reducionismo antes existente foi desafiado pela necessidade de se refletir sobre aspectos de ordem diversa, como o gerenciamento de conflitos distributivos, questões ambientais, a legitimação democrática do processo decisório estatal e a participação popular, mediante um processo de expansão das liberdades que as pessoas desfrutam.

Uma das facetas do desenvolvimento que passou a integrar as reflexões dos teóricos na área diz respeito ao aumento das capacidades e liberdades dos agentes econômicos. Essa concepção parte da percepção do indivíduo enquanto agente, no sentido de eliminar privações de liberdades que limitam a capacidade de escolha e oportunidades dos indivíduos de consolidar sua condição de agente. Nesse sentido, o desenvolvimento

\footnotetext{
${ }^{10}$ É evidente que os conceitos de redução da desigualdade e redução da pobreza não são equivalentes. A desigualdade compreende a comparação entre duas situações (renda, emprego, acesso a serviços essenciais, etc), enquanto que a pobreza é medida segundo padrões objetivos (estipula-se elementos mínimos de renda ou acesso a serviços para que se considere aquele abaixo desse padrão como pobres). Assim, considerando o fator renda, por exemplo, podem ocorrer situações em que há redução da pobreza absoluta pois uma quantidade maior de indivíduos superaram determinado padrão de renda que se considera mínimo, mas sem que haja, simultaneamente, a redução da desigualdade, pois a diferença de renda entre esses indivíduos e os demais se alargou.
} 
econômico passa a ser visto como um processo que relaciona as diversas esferas sociais, dentre elas a política, a econômica e a jurídica:

\begin{abstract}
"Perhaps the most important thematic deficiency of traditional development economics is its concentration on national product, aggregate income and total supply of particular goods rather than on entitlements of people and the capabilities these entitlements generate. Ultimately, the process of economic development has to be concerned with what people can or cannot do, e.g. wheter they can live long, escape avoidable morbidity, be well nourished, be able to read and write and communicate, take part in literary and scientific pursuits, and so forth." 11
\end{abstract}

Expandir as liberdades seria então condição e objetivo do desenvolvimento: a liberdade é um fim em si mesmo e, também instrumental, à medida que diferentes modalidades de direitos, oportunidades e capacidades contribuem para o gradual incremento da liberdade como um todo ${ }^{12}$.

A dissociação entre crescimento e desenvolvimento acentua o papel de outras esferas além da produtiva no processo de desenvolvimento. A inclusão das esferas social e política ratifica a percepção de que o Estado deve ter sim um papel importante nesse processo.

O conceito de Fábio Konder Comparato sumariza esses diferentes aspectos e enfatiza a dimensão pública do desenvolvimento, apontada pelo autor como inserto no contexto de políticas estatais referentes a três dimensões sobrepostas, a econômica, a social e a política:

\footnotetext{
"De qualquer modo, já se estabeleceu um razoável consenso no sentido de que o desenvolvimento é um processo de longo prazo, induzido por políticas públicas ou programas de ação governamental em três campos interligados: econômico, social e político. O elemento econômico consiste no crescimento endógeno sustentatado da produção de bens e serviços. (...) O elemento social do processo desenvolvimentista é a aquisição da progressiva igualdade de condições básicas de vida, isto é, a realização para todo o povo, dos direitos humanos de caráter econômico, social e cultural, como o direito ao trabalho, o direito à educação em todos os níveis, o direito à seguridade social (saúde, previdência e assistência social), o direito à habitação e o direito de fruição de bens culturais. Enfim, o desenvolvimento integral comporta, necessariamente, um elemento
}

${ }^{11}$ Cf. Amartya Sen. Development: which way now?, In The Economic Journal, Vol. 93, No. 372 (1983), p. 754.

${ }^{12}$ Cf. Amartya Sen, Desenvolvimento como liberdade, São Paulo: Companhia das Letras, 2000, pp. 32-33. 
político, que é a chave da abóboda de todo o processo: a realização da vida democrática, isto é, a efetiva assunção, pelo povo, do seu papel de sujeito político, fonte legitimadora de todo o poder e destinatário do seu exercício." 13

As políticas estatais devem ser repensadas e reestruturadas para que, além da geração de crescimento, existam mecanismos distributivos que garantam a apropriação de efeitos positivos aos demais cidadãos, reduzindo-se assim a desigualdade. Dessa forma, a ação do Estado deve, necessariamente, contemplar a necessidade de políticas econômicas e sociais de cunho distributivo. E a atuação do estado deve se dar tanto na redistribuição de riqueza e criação de condições para que os indivíduos possam desenvolver sua capacidade de escolha, quanto com o fim de incrementar o crescimento das atividades produtivas, notadamente através do incentivo à inovação.

O papel do Estado nesse contexto não é negligenciável. Ao contrário, o Estado apresenta-se como ator central na formulação de políticas desenvolvimentistas, seja mediante atuação regulatória (normativa), repressiva (controle e fiscalização das atividades dos particulares), ou participação direta na economia, com empresas estatais ou investimentos nas atividades privadas (incentivos fiscais, bancos de desenvolvimento, venture capital, e outros).

Extrai-se daí que o desenvolvimento compreende uma importante dimensão pública, relacionada à ação estatal. Assim, embora as diferentes noções de desenvolvimento sejam constituídas por elementos comuns, o peso de cada um desses elementos e o modo de se atingi-los são objeto de divergência. Como resultado, ainda que o rol de objetivos dos Estados tenha uma base comum e facilmente identificável (gerar desenvolvimento, entendido como eficiência produtiva e redução da desigualdade), o problema resta na definição sobre como alcançar essas metas.

Uma das dimensões fundamentais na definição do "como" fazer é a da política econômica, ou seja, o conjunto de ações do estado sobre os mercados. Dentro dele, emergem subgrupos específicos de políticas como a política industrial, cambial, fiscal, monetária e de crédito, concorrencial e outras. A definição das estruturas operativas dessas

\footnotetext{
${ }^{13}$ A afirmação histórica dos direitos humanos, São Paulo: Saraiva, 1999, p. 363.
} 
políticas e a interação entre elas é fundamental para a evolução do processo de desenvolvimento e se dá mediante atuação do Poder Executivo.

É nesse sentido que, como já destacado, a política econômica, embora apresente uma base principiológica originada de uma opção de Estado comumente adotada em diversos países (crescimento das atividades produtivas e redução das desigualdades), sujeita-se às escolhas de governos específicos quanto aos limites e significados dos princípios alçados pelo estado por meio de regras jurídicas e, especialmente, quanto aos meios para se efetivar tais princípios.

\subsection{Definindo a estrutura operativa da política econômica: direito como objetivo e ferramenta e a economia como instrumento de análise fática}

Definir quais aspectos se inserem na noção de desenvolvimento pode sujeitar a variações conforme as normas de direito positivo. Ou seja, as normas jurídicas podem eleger metas e objetivos necessariamente compreendidos na noção de desenvolvimento. Do mesmo modo, as ferramentas a serem utilizadas para o alcance desses objetivos podem ser influenciadas ou determinadas por regras jurídicas. Pode-se dizer então que o direito elege princípios e regras que devem, necessariamente, integrar as reflexões acerca do que se entende por desenvolvimento e quais são os meios para que se possa atingi-lo.

No que concerne à esfera política do processo de desenvolvimento, por exemplo, o Direito tem cada vez mais desempenhado um papel modificador, ou seja, tem sido capaz de desenvolver mecanismos que asseguram à população maior autonomia em seu processo decisório no campo político. A evolução social, influenciada pelo Liberalismo, no sentido de que fossem assegurados aos homens os direitos de consciência e de escolha, agrupados sinteticamente sob a denominação de direitos humanos de primeira dimensão ou geração, impulsionou uma série de mudanças sociais e políticas, como a consolidação da doutrina dos direitos humanos e a expansão de movimentos democráticos no século XX. 
Entretanto, essa capacidade de influência tem se revelado menos intensa nas esferas econômica e social, pois, não conseguindo imiscuir-se a dogmas de determinismo econômico, o elemento jurídico tem sido relegado a instrumento para a concretização de políticas econômicas e sociais sem desempenhar, muitas vezes, um papel relevante no sentido de adicionar elementos que influenciam a própria formulação dessas políticas em seus aspectos materiais.

Sob um pretenso manto de pureza científica e tecnicismo, muitas políticas econômicas são tratadas como de acesso e influência exclusivas da ciência econômica. A política monetária é um claro exemplo de insulamento legitimado por um alegado tecnicismo: dado que a política econômica interfere sobre questões complexas do ponto de vista da técnica econômica, justificar-se-ia certo grau de insulamento de suas decisões.

De outro lado, valer notar que certos âmbitos da política econômica são nitidamente influenciados por normas jurídicas. A formulação da política fiscal, por exemplo, é nitidamente influenciada pelo arcabouço jurídico que a disciplina, sendo que os princípios jurídicos da capacidade contributiva, não-confisco, anterioridade, e outros, alcançam um peso relevante na definição dos meios de operação dessa política.

É inegável que existe uma esfera de discricionariedade na elaboração das políticas econômicas, que encerram decisões políticas sobre preferências e preteridos. No entanto, num regime democrático, em que os agentes públicos têm mandato e estão sujeitos à responsabilização, essas decisões devem ser justificadas e fundamentadas. Nesse ponto, a fundamentação da política econômica não pode ser arbitrária e nem pensada em abstrato, a partir exclusivamente de modelos econômicos; a ação política deve ser pautada e estar de acordo com o ordenamento jurídico, que já encerra uma série de decisões políticas pretéritas e vinculativas, limitando ex ante as possibilidades de escolhas entre preferências e preteridos ex post.

No que diz respeito a países como o Brasil, em que existe um amplo corpo de normas de direito positivo, tanto constitucional quanto infraconstitucional, que disciplina a ordem econômica e social, imperioso ponderar na formulação das políticas econômicas o 
quanto disposto por essas normas ${ }^{14}$. Nesse sentido, a formulação de uma política econômica deve compreender uma etapa de interpretação dos princípios e regras jurídicas aplicáveis. É nesse momento, no âmbito da atividade interpretativa, que a teoria econômica pode ter uma participação relevante.

As políticas econômicas do Poder Executivo interferem diretamente sobre a economia, seja mediante atuação regulatória (normativa), repressiva (controle e fiscalização das atividades dos particulares), ou participação direta na economia. Daí decorre que o substrato econômico da ação não pode ser desconsiderado. Nesse sentido, a atuação sobre um mercado específico não pode deixar de considerar as particularidades desse mercado. O meio de se fomentar a inovação, por exemplo, pode ser distinto no mercado de telefonia em relação aos mercados agropecuários.

A teoria econômica constitui assim uma ferramenta relevante numa análise que é jurídica. Em outras palavras, a interpretação das normas de direito positivo que incidem diretamente sobre a dinâmica de mercados é uma análise jurídica que deve incorporar elementos e ferramentas da análise econômica.

Ressalte-se que não são somente aspectos econômicos que devem ser sopesados na elaboração e aplicação do Direito. Existem fatores de ordem sociológica, histórica e da própria concepção do ordenamento jurídico que devem integrar o processo de construção do Direito. No entanto, quando se trata especificamente de aspectos de intervenção sobre a economia, sua relação intrínseca com a dimensão do crescimento econômico eleva aspectos do raciocínio econômico a elementos essenciais na construção do Direito.

Nesse sentido, ainda que o exame pondere questões históricas ou sociológicas, a conformação econômica dos fatos sociais é essencial. Por isso, o exame da situação fática sobre a qual incide a norma jurídica deve congregar elementos econômicos como um dos

\footnotetext{
${ }^{14}$ Uma das dificuldades nessa tarefa é justamente definir o significado concreto das normas jurídicas, especialmente no campo do Direito Econômico, em que o recurso a fórmulas abertas pelo Legislador é comum: "L'instrumentalisme du droit économique apparaît également dans la plasticité des concepts utilisés. (...) Le juge, l'administrateur, à qui il incombe d'appliquer le droit économique, ne peuvent se satisfaire de tels concepts théoriques: ils doivent leur donner un contenu normatif sous peine de sombrer dans l'arbitraire. Ceci pose des problèmes fort complexes, relatifs au contrôle juridictionnel des décision concrètes." (Alexis Jacquemin e Guy Schrans, Le droit économique, 3. ed., Paris: Universitaires de France, 1982, p. 100).
} 
fatores de legitimação da interpretação dada. Em outras palavras, a melhor resposta neste caso passa necessariamente pela ponderação de elementos de análise econômica.

Isso não significa, no entanto, uma sujeição do Direito à Economia ${ }^{15}$; trata-se de ponderação, de utilização de uma análise pautada em elementos da ciência econômica para compreensão de uma situação fática com o fim de operacionalizar o funcionamento de regras de direito positivo, cuja racionalidade e objetivos, podem, muitas vezes, não se alinhar aos objetivos de eficiência econômica. Pode-se dizer então que os elementos de análise econômica são instrumentais ao exame da situação fática e sua compreensão, influenciando a interpretação jurídica.

\subsection{A questão regional como objeto das políticas econômicas do Estado: a justificativa jurídica e econômica}

A desigualdade entre os cidadãos ou regiões de um país em variadas dimensões renda, escolaridade, nível de produtividade, etc - tem sido apontada como um elemento que dificulta o desenvolvimento do país como um todo. Nesse sentido, são crescentes os estudos que indicam que sociedades menos desiguais apresentam trajetórias de desenvolvimento mais sustentáveis em comparação com sociedades mais desiguais ${ }^{16}$.

A desigualdade inibe o crescimento das atividades produtivas e deprime a demanda no mercado doméstico, fazendo com que a persistência de padrões de desigualdade ao longo do tempo torne ainda mais difícil a redução da pobreza e o crescimento econômico. Assim, países muito desiguais crescem em ritmo mais lento o que torna o problema da desigualdade não apenas uma consequência do subdesenvolvimento, mas também um dos seus fundamentos.

\footnotetext{
${ }^{15}$ A rejeição da situação de submissão e a defesa da complementaridade entre direito e economia é defendida por Paula A. Forgioni, Análise econômica do Direito (AED): paranóia ou mistificação?, in Revista de Direito Mercantil, Industrial, Econômico e Financeiro 139 (2005), p. 256.

${ }^{16}$ A respeito do problema da desigualdade em suas variadas formas ver Richard Wilkinson e Kate Pickett, The Spirit Level - Why More Equal Societies Almost Always Do Better, Allen Lane, 2009. Para um estudo focado nos efeitos da desigualdade de renda sobre o desenvolvimento ver Tony Addison e Giovanni Cornia, Income Distribution Policies for Faster Poverty Reduction, WIDER Discussion Paper n. 93, UNU-WIDER, 2001.
} 
Essa constatação é fundamental, pois evidencia que a desigualdade numa sociedade, expressa em suas diversas facetas, muito além de um problema moral, é também um problema instrumental ao alcance da eficiência produtiva e consequente crescimento econômico. Reduzir a desigualdade torna-se elemento fundamental para o crescimento do país.

A sociedade brasileira é marcada por diversas facetas da desigualdade: renda, gênero, raça. Uma faceta relevante é também a espacial: diferentes regiões apresentam disparidades substantivas quanto à composição e estrutura de suas economias, acesso a serviços públicos e inserção na ação política. A evolução econômica do Brasil resultou em uma situação de desequilíbrio entre regiões, havendo uma segmentação de áreas reconhecidas como pólos de desenvolvimento e outras marcadas por severa estagnação econômica.

Esse quadro da realidade nacional, marcado por pobreza e disparidades sociais e regionais, acabou por ser expressamente reconhecido em nível constitucional. Para Alberto Venâncio Filho, "a unidade nacional não poderia compadecer com essa posição de desequilíbrio, conservando na mesma unidade política regiões com tão grandes disparidades econômicas." ${ }^{17}$ Como resultado, no caso específico do direito positivo brasileiro, a análise do desenvolvimento passa necessariamente por aspectos de desenvolvimento regional.

Nesse contexto, a partir principalmente da Constituição de 1946, o que se convenciou denominar "questão regional" passou a ser parte dos debates, e "desde então, todas as Constituições brasileiras têm a preocupação de tentar consagrar instrumentos para a superação das desigualdades regionais" ${ }^{18}$. A Constituição Federal de 1988 reflete essa preocupação em seu art. $3^{\circ}$.

\footnotetext{
${ }^{17}$ A intervenção do Estado no domínio econômico - O Direito Público Econômico no Brasil, ed. fac-similar da de 1968, Rio de Janeiro: Renovar, 1998, p. 347.

${ }^{18}$ Gilberto Bercovici, Constituição econômica e desenvolvimento - uma leitura a partir da Constituição de 1988, São Paulo: Malheiros, 2005, p. 89. O autor se refere ainda a considerações acerca da desigualdade regional já na presidência de Epitácio Pessoa (1919-1922) e na Constituição de 1934, que previa em seu art, 177 um plano federal de combate às secas (Ibidem, p. 88).
} 
Esse dispositivo constitucional elenca uma série de objetivos que se relacionam de modo determinístico, ou seja, cada um dos objetivos condiciona o alcance do outro, de modo que para se efetivar um dos objetivos deve-se buscar também os demais. Nesse sentido, o desenvolvimento nacional (inciso II do art. $3^{\circ}$ ) compreende necessariamente o alcance de uma sociedade livre, justa e solidária (inciso I), a erradicação da pobreza e a marginalização e a redução das desigualdades sociais e regionais (inciso III), e a promoção do bem de todos, sem quaisquer formas de discriminação (inciso IV) ${ }^{19}$.

Assim, a Constituição Federal estabelece verdadeira cláusula transformadora ${ }^{20}$, que impõe ao Estado o dever de promover o desenvolvimento regional, alçando esse aspecto a um dos elementos que deve integrar a concepção de desenvolvimento econômico a ser procurada pelo Estado brasileiro, definindo assim os parâmetros das ferramentas a serem utilizadas nas políticas econômicas do governo ${ }^{21}$.

O controle da adequação das escolhas políticas do Estado em face desse dispositivo constitucional deve compreender ponderações econômicas, já que diz respeito ao substrato social e às relações econômicas estabelecidas. Afinal, a formulação e aplicação do Direito não deve se descolar da realidade social e econômica. Por isso, as ponderações de ordem econômica se encontram presentes tanto no momento de formulação das regras de direito positivo, norteando os debates na esfera política acerca de quais elementos e ferramentas serão escolhidos pelas normas de direito positivo, quanto no momento de aplicação das normas jurídicas, já que a interpretação dos comandos normativos também deve ponderar esses $\operatorname{aspectos}^{22}$. Nesse sentido, a definição de quais atos normativos e respectivas

\footnotetext{
19 “Art. $3^{\circ}$ Constituem objetivos fundamentais da República Federativa do Brasil:

I - construir uma sociedade livre, justa e solidária;

II - garantir o desenvolvimento nacional;

III - erradicar a pobreza e a marginalização e reduzir as desigualdades sociais e regionais;

IV - promover o bem de todos, sem preconceitos de origem, raça, sexo, cor, idade e quaisquer outras formas de discriminação."

${ }^{20}$ Gilberto Bercovici, Desigualdades regionais, estado e constituição, São Paulo: Max Limonad, 2003, p. 294.

${ }^{21}$ Nesse sentido, ver Eros Grau, A ordem econômica na Constituição de 1988, 9. ed, São Paulo: Malheiros, 2004 , p. 203.

${ }^{22}$ Nas palavras de Eros Grau, "interpretar/aplicar o direito é concretizá-lo, ir dos textos e dos fatos à norma jurídica geral e, em seguida, à norma de decisão, no desenvolvimento de uma prudência; por isso, não existe, no direito, uma única solução correta, senão várias. Em síntese: a interpretação do direito tem caráter constitutivo - não, pois, meramente declaratório - e consiste na produção, pelo intérprete, a partir de textos normativos e dos fatos atinentes a um determinado caso, mediante a definição de uma norma de decisão." (Ibidem, p. 147).
} 
interpretações seriam constitucionais tendo em vista o dispositivo mencionado passa por um exame econômico da situação fática.

Ressalte-se novamente que não são somente aspectos econômicos que devem ser sopesados na elaboração e aplicação do Direito. Existem fatores de ordem sociológica, histórica e da própria concepção do ordenamento jurídico que devem integrar seu processo de construção. No entanto, como discutido acima, o exame da situação fática sobre a qual incide a norma jurídica deve congregar elementos econômicos como um dos fatores de legitimação da interpretação dada.

Afinal, considerando especificamente a questão do desenvolvimento regional alçado a objetivo do Estado brasileiro por uma norma de direito positivo de nível constitucional - muitas estratégias poderiam ser pensadas para que as políticas econômicas promovam o desenvolvimento regional. Inclusive, a própria abstenção estatal poderia ser a estratégia mais adequada para se concretizar esse objetivo, caso se considerasse a atuação estatal inócua ou mesmo prejudicial. É neste ponto que o exame econômico dos fatos sociais torna-se imprescindível para se encontrar a interpretação adequada do dispositivo jurídico. O exame econômico permitirá a avaliação da situação fática para que sejam definidos os institutos jurídicos mais adequados e eficientes para a concreção do objetivo estipulado pelo Direito (nesse ponto, a eficiência não é o fim do Direito, mas sim uma qualificação de sua formulação tendo em vista os objetivos pretendidos).

Muitos trabalhos relevantes foram dedicados ao exame das políticas econômicas do Estado brasileiro com o fim de fomentar o desenvolvimento regional. Esses estudos abordaram principalmente elementos de "economia real". ${ }^{23}$ Contudo, esses estudos não examinaram, especificamente, aspectos pertinentes ao sistema financeiro, que responderia passivamente às alterações na economia real. Dessa forma, as políticas econômicas de intervenção sobre o setor financeiro não têm sido examinadas sob a perspectiva do desenvolvimento regional, motivo pelo qual essa dimensão constitui o objeto central deste trabalho.

\footnotetext{
${ }^{23}$ Economia real é uma expressão utilizada para diferenciar os setores da economia voltados à produção, distribuição e consumo de bens materiais do setor financeiro e de mercado de capitais.
} 


\subsection{Autonomia, cientificização e accountability: a intervenção sobre o sistema} financeiro e a necessidade de ponderação de aspectos de desenvolvimento regional

No que diz respeito especificamente às políticas de intervenção sobre o sistema financeiro, existe ampla literatura que preconiza a neutralidade da moeda e do sistema bancário no desenvolvimento regional. Nesse sentido, a ponderação desses elementos na interpretação jurídica poderia levar à conclusão de que a melhor forma de atuação do Estado para promoção do desenvolvimento regional no que diz respeito ao sistema financeiro é a abstenção ou, no máximo, não ultrapassa a esfera de atuação, em geral recomendada por diversos teóricos e aceita por diversos governos, de que o Estado deve limitar-se a garantir a estabilidade monetária, por meio de uma política monetária de contenção da inflação e uma regulamentação e fiscalização das instituições financeiras que garanta a higidez do sistema ${ }^{24}$.

Como se discute a seguir, a limitação da intervenção do Estado sobre o sistema bancário tem sido preconizada amplamente pelo que aqui se denomina de mainstream economics, um amplo grupo de pesquisadores e professores de economia que, assumindo a neutralidade dos fenômenos monetários sobre a economia real no longo prazo, apontam como adequados à política monetária e à regulação bancária unicamente os objetivos de estabilidade de preços e higidez financeira, respectivamente ${ }^{25}$. Essa defesa ganha a qualificação de ortodoxia por sua aceitação em diversos meios, procurando alcançar o caráter de consenso e de mais apurada ciência.

Após crises inflacionárias enfrentadas na década de 1980 em razão essencialmente de abusos cometidos na gestão da moeda, autoridades monetárias de vários países (em geral, há uma identidade entre autoridade monetária e banco central) passaram a apostar com maior vigor nessa concepção. Nesse sentido, a estabilidade macroeconômica passou a ser considerada o principal - muitas vezes o único - objetivo da atuação do estado sobre o

\footnotetext{
${ }^{24} \mathrm{O}$ item 2.5 é dedicado à exposição da ampla aceitação na teoria e na prática desses objetivos como os únicos a serem perseguidos pela autoridade monetária.

${ }^{25}$ As referências a autores compreendidos no mainstream serão feitas no capítulo 2, quando essas teorias são analisadas em detalhes.
} 
setor bancário, tanto na elaboração da política monetária quanto da regulação financeira ${ }^{26}$, e aos bancos centrais foi conferida maior autonomia, seja por reformas legislativas ou por mudanças informais nas relações entre organizações do governo, para que os abusos políticos fossem evitados e uma burocracia técnica e que não pautasse duas decisões pelo cálculo político de curto prazo pudesse estruturar mecanismos de intervenção capazes de garantir a estabilidade ("despolitização").

A maior autonomia alcançada por bancos centrais trazia uma série de questões quanto aos meios e oportunidades para avaliação das escolhas feitas e eventual responsabilização de seus dirigentes (o que se denomina amplamente na literatura de accountability, utilizando a expressão em língua inglesa). Essas questões se tornam ainda mais prementes à medida que um processo de alegada cientificização das decisões das autoridades monetárias se encontra em curso, o que as tornaria apolíticas ${ }^{27}$.

Bancos centrais em países desenvolvidos têm sustentado a existência de um consenso sobre a necessidade de que o papel da autoridade monetária seja limitado à garantia da estabilidade macroeconômica (aqui entendida como estabilidade de preços e higidez financeira). Esse consenso compreenderia a teoria econômica e a prática de bancos centrais em países desenvolvidos, e seria fundamentado em bases científicas. Significa dizer que seria cientificamente justificável e, por isso, possivelmente mais adequada tal limitação, de modo que os instrumentos de política monetária e a ação dos bancos centrais estariam se desenvolvendo sobre bases científicas.

O processo de "apolitização" das escolhas dos bancos centrais com base em alegado cientificismo de suas decisões ignora que a teoria econômica que embasa essa concepção está longe de ser um consenso, existindo diversas críticas e questionamentos ao postulado de neutralidade da moeda, além de evidências empíricas apontando a importância da moeda para o desempenho das economias, inclusive no longo prazo.

\footnotetext{
${ }^{26}$ Em algumas vezes, a autoridade pública responsável pela política monetária não é a mesma encarregada da regulação financeira. No entanto, dada a constante concentração das duas funções em uma só autoridade, o banco central, a análise neste trabalho assume essa concentração.

${ }^{27}$ Cf. Martin Marcussen, Institutional Transformation? The Scientization of Central Banking as a Case Study, in Tom Christensen and Per Laegreid (org.), Autonomy and Regulation - Coping with Agencies in the Modern State, Edward Elgar, 2006, pp. 82 e ss.
} 
Além disso, ignora que as autoridades monetárias, mesmo aquelas dotadas de autonomia, estão inseridas no contexto da política de desenvolvimento de um determinado Estado. Desse modo, sua escolhas ou decisões são políticas pois significam a determinação de preteridos e preferências, sendo sujeitas ao contexto econômico e social de cada país e a escolhas políticas pretéritas e vinculantes consubstanciadas no ordenamento jurídico de cada país. Em diversos países, inclusive no Brasil, há normas jurídicas dispondo sobre os objetivos do banco central, de modo que sua autonomia deve se limitar aos instrumentos para consecução desses objetivos (o que a literatura tem comumente denominado de instrument independence), não alcançando a definição dos objetivos a serem alcançados (a hipótese contrária seria a de goal independence $)^{28}$.

O ordenamento jurídico não pode ser ignorado, pois é ele que estabelece a divisão de atribuições entre a autoridade monetária e outros órgãos do Estado e confere legitimidade jurídico-formal a seus atos, devendo, necessariamente, ser considerado na formulação das políticas e em sua posterior avaliação. Em outras palavras, o ordenamento estabelece os contornos da ação dos bancos centrais, definindo os objetivos, conferindo os meios para execução e estabelecendo os parâmetros para sua avaliação e responsabilização por outros órgãos (accountability).

Por essas três razões essenciais - divergência na teoria econômica, condições econômicas e sociais díspares em cada país e regulamentação do poder monetário pelos ordenamentos jurídicos - os objetivos da política monetária e da regulação bancárias e seus parâmetros de avaliação devem ser revisitadas sob outro viés.

Nos próximos capítulos, propõe-se uma interpretação eminentemente sistemática do ordenamento jurídico levando em consideração elementos de análise econômica. Face a complexidade do tema e tendo em vista as diversas nuances a serem ponderadas, este trabalho tem como recorte temático um dos aspectos do desenvolvimento econômico, o desenvolvimento regional. Além disso, as diferenças no contexto econômico e no ordenamento jurídico dos diversos países recomendam um recorte para que seja objeto central do trabalho o caso brasileiro, em que, como já anotado acima, o desenvolvimento regional encontra status constitucional. Faz-se necessário então analisar em que medida

\footnotetext{
${ }^{28}$ Sobre as definições de goal independence e instrument independence ver Stanley Fischer, Central Bank Independence Revisited, in The American Economic Review, vol 85, n.2 (1995), p. 201.
} 
elementos de desenvolvimento regional devem integrar a racionalidade de intervenção do estado brasileiro sobre o sistema bancário e, portanto, conformar a política monetária e a regulação bancária.

Primeiro, procede-se a uma análise dos argumentos econômicos que sustentam a necessidade de intervenção estatal sobre o sistema bancário para fomentar o desenvolvimento regional. Nesse sentido, nas últimas décadas, diversos estudos teóricos e empíricos que debatem os impactos de sistema bancário sobre as regiões do país foram desenvolvidos. Segundo esses estudos, a atividade bancária pode também resultar em desenvolvimento desigual ou perpetuar essa condição.

A moeda e sua alocação não seriam neutras no processo econômico, mas, ao contrário, influenciariam as decisões dos agentes econômicos e teriam consequências a nível regional: existiriam alguns elementos nas escolhas e performance dos bancos instituições capazes de influenciar a disponibilidade e alocação de recursos financeiros que levariam a patamares de desenvolvimento desigual entre regiões, reforçando desigualdades regionais. Preconiza essa literatura que o livre jogo do mercado levaria, necessariamente, à perpetuação e extensão da desigualdade regional, sendo necessárias políticas públicas de intervenção sobre o sistema financeiro a fim de atenuar ou reverter essa tendência.

Portanto, tem-se de um lado uma questão fática cuja conformação em termos econômicos deve ser ponderada: em um país com contrastes regionais, o sistema financeiro tende, num cenário de livre jogo do mercado, intensificar essas desigualdades. Essa constatação é embasada em estudos teóricos e empíricos capazes de demonstrar essa tendência.

Após, a discussão volta-se ao ordenamento jurídico brasileiro, procurando evidenciar que esse ordenamento não ratifica a limitação do papel da autoridade monetária à garantia da estabilidade. Como se demonstrará, tanto a Constituição Federal quanto o ordenamento infraconstitucional conferem às autoridades monetárias um papel transformador e enfatizam sua importância no fomento ao desenvolvimento regional. 
Como resultado, dada a existência de um problema econômico identificado e a disciplina jurídica que o reconhece e procura construir ferramenta para sua mitigação, a ação das autoridades monetária deve se estruturar de modo a influenciar ou disciplinar o comportamento dos agentes econômicos para que o resultado desigualdade regional não se perpetue mas, contrariamente, sejam mitigados esses contrastes. Para tanto, a dinâmica econômica identificada por estudos teóricos e empíricos sugere que a política monetária e de crédito, incluindo a regulação das instituições bancárias, tenha como um de seus fundamentos e propósitos essa racionalidade, que deve, por isso, constituir parâmetro para a accountability das autoridades monetárias brasileiras. 


\section{MOEDA, SISTEMA FINANCEIRO E DESENVOLVIMENTO: O PAPEL DO CRÉDITO FINANCEIRO}

O papel do sistema financeiro no desenvolvimento é uma questão que tem sido reiteradamente discutida e sobre a qual pende substancial discordância nas análises e estudos sobre desenvolvimento. Diferentes teorias se estabeleceram e diversas pesquisas foram realizadas para examinar hipóteses acerca da relação de causalidade entre sistema financeiro e desenvolvimento e também para aferir o grau de encadeamento existente.

As diferentes hipóteses analisadas podem ser sumarizadas nas assertivas contrapostas "sistema financeiro gera crescimento do setor real" e "crescimento do chamado setor real é que gera o desenvolvimento do sistema financeiro". Essas hipóteses, inicialmente tidas como conflitantes, foram desenvolvidas e testadas em trabalhos teóricos e também em uma série de trabalhos empíricos que procuravam aferir o sentido dessa correlação $^{29}$.

Esse debate origina-se de uma crítica ao pensamento de autores ditos "pioneiros" nos estudos sobre desenvolvimento, os quais baseavam seus modelos de crescimento econômico unicamente em elementos de "economia real" 30 , ignorando aspectos pertinentes ao sistema financeiro, que responderia passivamente às alterações na economia real. Segundo essa concepção, o desenvolvimento econômico origina demanda por determinados arranjos financeiros, e o sistema financeiro responde diretamente a essa demanda mas não é, ele mesmo, um propulsor do desenvolvimento. Assim, para esses autores, haveria uma relação de predominância entre o setor real e o setor financeiro ("where enterprise leads finance follows") ${ }^{31}$.

A essa concepção contrapõe-se a percepção de que diferenças no funcionamento dos sistemas financeiros influenciam as taxas de crescimento econômico. Assim, o

\footnotetext{
${ }^{29}$ Uma síntese dessa bibliografia é apresentada por Ross Levine, Finance and Growth: Theory and Evidence, Working Paper n. 10766, National Bureau of Economic Research, disponível on-line in http://papers.ssrn.com/sol3/papers.cfm?abstract_id=592145.

${ }^{30}$ Como já esclarecido, economia real é uma expressão utilizada para diferenciar os setores da economia voltados à produção, distribuição e consumo de bens materiais do setor financeiro e de mercado de capitais.

${ }^{31}$ Joan Robinson, The Generalization of the General Theory, apud Ross Levine, Financial Development and Economic Growth - Views and Agenda, in Journal of Economic Literature 35 (1997), p. 688.
} 
desempenho do sistema financeiro e, consequentemente, sua estrutura, teriam influência direta e ativa sobre o desenvolvimento econômico, afetando as taxas de crescimento dos países, os níveis de inovação e também de desenvolvimento humano:

\begin{abstract}
"Access to finance is a crucial determinant of the development process in emerging market economies. Altough it may seem obvious now, this view was not always widely accepted. The tendency in development economics during most of the postwar era was to focus on the 'real' sector of the economy - namely, industrialization, technology transfer, and the international exchange of goods - with the financial sector relegated to sidelines.",32
\end{abstract}

Essa percepção é corroborada por uma série de estudos empíricos, principalmente pautados por análises comparativas entre países, que sugerem que diferenças no nível de desenvolvimento do sistema financeiro influenciam substancialmente o nível de desenvolvimento econômico, o que não significa, de outro lado, que a economia real não influencia o desenvolvimento financeiro. Essa relação também existe, constituindo-se assim uma relação de mão dupla, de influência recíproca, com evidência de correlação suficiente a alçar o sistema financeiro a objeto de pesquisa daqueles que querem debater desenvolvimento econômico ${ }^{33}$.

Dentre os aspectos mais relevantes no que diz respeito à relação entre desenvolvimento e sistema financeiro está a questão do crédito financeiro, conforme já noticiado por Schumpeter no início do século. Esse aspecto ganha ainda mais relevância no caso brasileiro. Note-se que o financiamento das atividades é geralmente atribuído ao sistema bancário e ao mercado de capitais, sendo recorrente na literatura a distinção entre países com modelos de financiamento baseados em bancos ou mercados de capitais. No caso brasileiro, a despeito do crescimento do mercado de capitais nos últimos anos, o financiamento bancário permanece sendo essencial para a captação de recursos pelos setores produtivos.

O crédito financeiro (originado na atividade de intermediação financeira exercida essencialmente pelos bancos) assume um papel central no crescimento das atividades

\footnotetext{
32 Barbara Stallings e Rogerio Studart, Finance for Development - Latin America in Comparative Perspective, Washington: Brookings, 2006, p. I.

${ }^{33}$ Para uma análise dos diversos trabalhos empíricos realizados ver Ross Levine, Financial Development and Economic Growth - Views and Agenda, op. cit., pp. 12 e ss.
} 
produtivas, pois cria disponibilidade de recursos para que os empresários (aqueles que desejam formar novas combinações, na acepção de Schumpeter) possam investir em novas combinações de bens e gerar novos estados de equilíbrio (inovação) ${ }^{34}$. O crédito financeiro é fator essencial ao desenvolvimento de uma sociedade no que diz respeito a crescimento econômico, ou seja, a crescimento de suas atividades produtivas, pois é condição essencial para que qualquer decisão de investimento possa ser tomada:

\begin{abstract}
"Nesse sentido, portanto, definimos o cerne do fenômeno do crédito da seguinte maneira: o crédito é essencialmente a criação de poder de compra com o propósito de transferi-lo ao empresário, mas não simplesmente a transferência de poder de compra existente. A criação de poder de compra caracteriza, em princípio, o método pelo qual o desenvolvimento é levado a cabo num sistema com propriedade privada e divisão do trabalho. Através do crédito, os empresários obtêm acesso à corrente social dos bens antes que tenham adquirido o direito normal a ela. Ele substitui temporariamente, por assim dizer, o próprio direito por uma ficção deste. A concessão de crédito opera nesse sentido como uma ordem para o sistema econômico se acomodar aos propósitos do empresário, como um comando sobre os bens de que necessita: significa confiar-lhe forças produtivas. É só assim que o desenvolvimento econômico poderia surgir a partir do mero fluxo circular em equilíbrio perfeito. E essa função constitui a pedra angular para a moderna estrutura de crédito." 35
\end{abstract}

Além disso, a disponibilidade de recursos financeiros estruturada e originada na atividade bancária proporciona recursos para que os cidadãos possam consumir os bens objeto da atividade produtiva, não só dando movimento e perpetuando o ciclo produtivo, mas também exercitando suas capacidades de escolha, o que amplia sua liberdade econômica.

Esse outro aspecto do crédito financeiro - de aumento das capacidades e liberdades dos agentes econômicos - diz respeito a outra faceta da noção de desenvolvimento econômico, que supera a simples concepção de crescimento desprovida de considerações redistributivas, e parte da percepção do indivíduo enquanto agente para propor a eliminação das privações de liberdades que limitam a capacidade de escolha e as oportunidades dos indivíduos. Expandir as liberdades seria então condição e objetivo do

\footnotetext{
${ }^{34}$ Segundo Schumpeter, o banqueiro cria poder aquisitivo, posicionando-se entre aqueles que desejam formar novas combinações (empresários) e os possuidores dos meios produtivos. Portanto, é ele quem proporciona novas combinações (inovação), sendo "essencialmente um fenômeno do desenvolvimento" (Joseph Schumpeter, Teoria do Desenvolvimento Econômico, op. cit., p. 103).

${ }^{35}$ Ibidem, p. 74.
} 
desenvolvimento e um dos elementos que seriam influenciados pela disponibilidade e alocação do crédito financeiro ${ }^{36}$.

Nesse contexto, o sistema financeiro, ao influenciar a disponibilidade e alocação de recursos financeiros na economia, desempenha funções essenciais ao processo de desenvolvimento, tanto em seu aspecto de crescimento das atividades produtivas quanto no aspecto referente à expansão das liberdades e consolidação da condição de agente. Destaca-se nesse contexto o papel exercido pelas instituições bancárias, principais responsáveis pela intermediação financeira e alocação do crédito financeiro ${ }^{37}$.

Por meio do sistema bancário, os mais diversos agentes econômicos interagem indiretamente, através da transferência de recursos de agentes econômicos que depositam seu capital nas instituições bancárias e seu repasse para outros, que procuram capital. Conhecida como intermediação financeira, essa atividade permite que recursos financeiros diversos sejam agrupados para o investimento em atividades produtivas.

Os bancos recolhem os recursos dispersos pela população e, conservando apenas uma parcela dos depósitos para atender aos saques dos depositantes, direcionam parcela expressiva dos recursos captados àqueles que necessitam de empréstimos ${ }^{38}$, gerando assim maior quantidade de capital disponível na economia para investimento. Uma vez que o capital emprestado é novamente depositado, será na sequência emprestado a outro agente econômico e assim por diante, gerando o efeito multiplicador que dá origem à denominada moeda escritural ou bancária ${ }^{39}$.

Desse modo, as instituições bancárias têm o poder de criar moeda e influenciar a quantidade de recursos financeiros existente na economia. Além disso, a alocação desses recursos também é determinada pelas instituições bancárias, tanto por meio das

\footnotetext{
${ }^{36}$ Essa noção de desenvolvimento econômico parte da percepção do indivíduo enquanto agente, no sentido de eliminar privações de liberdades que limitam a capacidade de escolha e oportunidades dos indivíduos de consolidar sua condição de agente. Expandir as liberdades seria então condição e objetivo do desenvolvimento. Nesse sentido, ver Amartya Sen, Desenvolvimento como liberdade, op. cit., pp. 32-33.

${ }^{37}$ Uma discussão sobre as peculiaridades do sistema bancário pode ser encontrada em Gerald Corrigan, Are Banks Special?, Annual Report Essay, Federal Reserve Bank of Minneapolis, 1982, disponível on-line in http://www.minneapolisfed.org/pubs/ar/ar1982a.cfm.

38 Os bancos realizam o negócio jurídico de crédito, ou seja, tornam-se devedores daqueles que neles realizam depósitos com o único objetivo de se tornar credores, utilizando-se desse capital.

${ }^{39}$ Para uma exposição detalhada ver José Tadeu De Chiara, Moeda e Ordem Jurídica, Tese de Doutorado, Faculdade de Direito da USP, 1986, capítulo IV.
} 
modalidades de captação de recursos adotadas - que podem incentivar captações de longo ou curto prazo - quanto pelos instrumentos de repasse escolhidos.

Dessa forma, a quantidade de ativos de alta liquidez disponíveis na economia é influenciada pela alternância dos instrumentos de captação dos bancos, que ora oferecem condições mais vantajosas para investimentos de longo prazo, ora priorizam - e conseqüentemente incentivam - investimentos ou aplicações de curto prazo. Por sua vez, as modalidades de captação utilizadas pelos bancos influenciam, em geral, a alocação dos recursos disponíveis pelas instituições bancárias. Assim, elas podem utilizar recursos captados em aplicações de longa duração para financiar projetos de maturação dilatada, com prazos de pagamento estendidos, ou priorizar captações de curta duração ou mesmo à vista para financiamentos de prazo limitado, em geral atrelados ao consumo e capital de giro de empresas.

A alocação de recursos na economia é ainda influenciada pelo sistema bancário à medida que constitui uma rede capaz de viabilizar um sistema de pagamentos que congrega transferências bancárias, compensações de cheques e outras atividades. Esse sistema é essencial para o trânsito de recursos entre agentes econômicos e o dinamismo do cumprimento das obrigações estabelecidas numa economia, permitindo que as obrigações sejam liquidadas sem a transferência direta de papel-moeda. Infinita maioria das transações é liquidada mediante pagamento realizado por meio da transferência de crédito dentro do sistema bancário, mediante papéis (como cheques) ou instrumentos (cartão de crédito) que são transmitidos pelo sistema de compensações inter-bancárias ${ }^{40}$.

Os pagamentos consistem na troca de pretensões de crédito: o credor recebe em pagamento do crédito junto ao devedor um crédito que este detém junto a um banco. Em outras palavras, o credor aceita como forma de liquidação da obrigação junto ao devedor, sua substituição por outro devedor, o banco, sem que tenha havido nenhuma transferência direta de papel-moeda. Substitui-se uma pretensão por outra pretensão, alterando-se apenas

\footnotetext{
40 "Economias modernas são dependentes dos depósitos à vista como meios de pagamento.Quando se tomam as estatísticas de meios de pagamento divulgadas pelos bancos centrais, percebe-se que papel moeda é hoje responsável por uma fração irrisória dos pagamentos feitos em qualquer economia menos primitiva." (Fernando Cardim Carvalho, O papel do Banco Central no processo de regulação financeira, in Celso $\mathrm{F}$. Campilongo, Jean Paul C. Veiga da Rocha e Paulo T. Lessa Mattos (org.), Concorrência e Regulação no Sistema Financeiro, São Paulo: Max Limonad, 2002, p. 260-1).
} 
o sujeito passivo da obrigação. Isso somente é possível em razão do grau de segurança e liquidez que diferencia os devedores. Os bancos são devedores mais líquidos e, usualmente, não se negam a pagar sua dívidas. Por isso, trocar uma pretensão perante um devedor por uma pretensão perante um banco incrementa o nível de segurança do credor e sua situação de liquidez ${ }^{41}$.

Depreende-se então que o sistema de pagamentos perpetua o ciclo de criação de moeda escritural, intensificando o poder das instituições bancárias de criar moeda e definir a quantidade de recursos financeiros existente na economia.

\subsection{Autoridade monetária e controle da liquidez}

Essa breve descrição da atividade bancária deixa clara sua correlação com a ordem monetária. O crédito origina-se da moeda e, ao mesmo tempo, pode criá-la, influenciando a própria conformação das funções da moeda ${ }^{42}$.

Primeiro, o crédito constitui renúncia de moeda pelo credor - ou como examinado à frente, de liquidez - em favor do pagamento de juros por aquele que necessita de moeda para que possa se habilitar a desenvolver determinado projeto. E o negócio jurídico de crédito só se aperfeiçoa quando se tem confiança no poder liberatório, na aceitação da moeda como intermediária de trocas e padrão de valor e, principalmente, na conservação do poder de compra da moeda ao longo do tempo.

De outro lado, toda vez que um banco concede crédito está criando moeda. A expansão do crédito por instituições bancárias, em razão da dinâmica de multiplicação da moeda relacionada a essa expansão, pode levar a um incremento significativo da base monetária e em escala superior ao crescimento dos meios produtivos. Desse modo, o incremento do volume de crédito financeiro pode contribuir para a perpetuação ou início

\footnotetext{
${ }^{41}$ Cf. José Tadeu De Chiara, Moeda e Ordem Jurídica, op. cit, pp. 81-82.

${ }^{42}$ Sobre as funções da moeda, a análise de José Tadeu De Chiara é fundamental: Moeda e Ordem Jurídica, op. cit, pp. 27 e ss.
} 
de um processo inflacionário capaz de comprometer a função de reserva de valor da moeda.

Nesse sentido, enquanto, de um lado, a atividade de intermediação financeira exercida pelos bancos assume um papel central no financiamento das atividades produtivas e do consumo, fomentando o desenvolvimento econômico, pode também, ao revés, constituir um óbice ao desenvolvimento, seja pela ampliação excessiva do volume de crédito (e moeda), gerando o descontrole da inflação, seja mediante crises bancárias ou mesmo pelo aproveitamento ineficiente dos recursos disponíveis.

A inflação implica na corrosão das funções de reserva e padrão de valor da moeda, desestabilizando todo o sistema monetário. Isso porque a estabilidade do valor da moeda é condição necessária a que o sistema contratual seja possível, garantindo a possibilidade de organização das atividades produtivas mediante a atenuação de incertezas quanto ao futuro $^{43}$. Por sua vez, a inflação gera incerteza e afeta profundamente as atividades privadas de longa-duração - como investimentos produtivos e financiamentos de longo prazo - estimulando assim iniciativas meramente especulativas. As bases de cálculo de custos e lucros se tornam mais incertas que no período sob relativa estabilidade, já que os custos não podem mais ser controlados mediante contratos a termo. Dessa forma, contextos inflacionários exigem políticas restritivas, elevando os juros e ampliando o nível de desemprego ${ }^{44}$.

De outro lado, aspectos da composição estrutural do sistema bancário resultam em preocupações acerca do risco a ser suportado pelas instituições financeiras em sua atividade, tendo em vista a proteção dos investidores e do sistema como um todo. A intermediação financeira resulta em uma constituição estrutural que deixa os bancos suscetíveis ao risco sistêmico. Isso porque existe um descasamento entre o ativo e o passivo dos bancos, uma vez que seu patrimônio é constituído por débitos exigíveis à vista em grande parte, enquanto seus créditos são integrados pelos empréstimos feitos pelos bancos, na grande maioria das vezes exigíveis a prazos mais dilatados. Essa constituição

\footnotetext{
${ }^{43}$ Esse ponto será discutido com detalhes à frente, no capítulo 3.

${ }^{44}$ Fernando Cardim Carvalho, Alta inflação e hiperinflação: uma visão pós-keynesiana, in Revista de Economia Política n. 10 (1990), p. 71.
} 
patrimonial dos bancos significa que as instituições bancárias podem ter seus débitos exigidos a qualquer tempo, enquanto seus créditos não o são. ${ }^{45}$

Essa peculiar composição estrutural dos bancos os expõe a crises de confiança. Quando os depositantes passam a desconfiar da capacidade dos bancos de honrar seus compromissos de pagar em moeda e à vista os valores depositados, os depositantes podem decidir sacar os valores mantidos em depósito, gerando corridas bancárias. Como os bancos mantêm efetivamente em seu poder quantidades de moeda representativas de apenas parte dos valores registrados em depósito (apenas para atender necessidades regulares de liquidez), os bancos não seriam capazes de atender uma demanda expressiva e concomitante por moeda.

Essas possíveis crises de confiança somadas ao fato de que os bancos necessariamente mantêm relações de crédito entre si, para compensações de pagamentos ou mesmo pela realização de empréstimos interbancários, originam o chamado risco sistêmico. O risco sistêmico no setor bancário caracteriza-se pela possibilidade de que a quebra de uma instituição cause dificuldades generalizadas em outras instituições, podendo resultar na quebra também destas. Em outras palavras, um evento independente, a quebra de uma instituição, pode gerar a quebra de outras.

O risco sistêmico está subordinado à verificação de um evento sistêmico, que se compõe por um acontecimento gerador do evento sistêmico, denominado de "choque", e por mecanismos capazes de propagar o choque ("mecanismos de propagação") ${ }^{46}$. No sistema bancário os choques podem ser acontecimentos como a quebra de uma ou mais instituições ou a divulgação de informações sobre a situação patrimonial dessas instituições, que podem, pelos mecanismos de propagação, afetar outras instituições

\footnotetext{
45 "É exatamente essa característica nos balanços patrimoniais dos bancos que tornam essas instituições vulneráveis a crises de confiança. Tais crises podem acarretar em corridas bancárias, as quais acontecem quando os depositantes decidem sacar os valores depositados por temerem que os bancos não terão capacidade de honrar seus compromissos de pagar à vista e em moeda todo o valor depositado. A razão desta fragilidade reside no fato de que os bancos não mantêm em dinheiro todos os valores registrados em depósito, mas apenas uma pequena parte dessas quantias para que possam atender as necessidades normais de liquidez. Assim, caso todos os depositantes decidam sacar seus valores simultaneamente, qualquer banco irá insolvência." (Tiago Machado Cortez, O conceito de risco sistêmico e suas implicações para a defesa da concorrência no mercado bancário, in Celso F. Campilongo, Jean Paul C. Veiga da Rocha e Paulo T. Lessa Mattos (org.), Concorrência e Regulação no Sistema Financeiro, São Paulo: Max Limonad, 2002, p. 319).

${ }^{46}$ Cf. Olivier de Bandt e Philipp Hartmann, Systemic Risk: a Survey, Working Paper n. 35, European Central Bank, 2000, p. 10.
} 
financeiras. Assim, determinado acontecimento é capaz de atingir diversas instituições, independente de suas ações.

A estrutura patrimonial dos bancos e o modo como se dá sua relação com os clientes intensificam os possíveis mecanismos de propagação de um eventual choque, capaz de desencadear um evento sistêmico. Isso porque o descasamento entre ativo e passivo e a assimetria de informações existentes entre os bancos e seus clientes pode transformar uma crise de confiança em uma corrida bancária, uma vez que a crise de uma instituição bancária pode abalar a confiança em todo o sistema de garantir a liquidez dos depósitos. Além desse mecanismo informacional de propagação, é possível apontar também o referente às exposições reais entre bancos. Os bancos se relacionam entre si para fazer compensações e transferências entre instituições originadas das relações organizadas pelo sistema de pagamentos e para o controle de liquidez das instituições, através do mercado interbancário, à medida que um banco pode financiar a necessidade de liquidez de outro.

Uma crise bancária pode ter consequências muito impactantes sobre a economia, compreendendo a escassez de recursos para investimentos e, ainda mais grave, a quebra da confiança no padrão monetário. As características peculiares do sistema bancário implicam numa capacidade de impactar diretamente o regime monetário e a capacidade da moeda de servir como instrumento de troca, padrão e reserva de valor. Muito além disso, numa economia monetária, todo o sistema de contratos está pautado pela moeda e suas funções, de modo que a falha do sistema monetário em cumprir suas funções resulta em queda nos padrões produtivos e na capacidade de desenvolvimento da sociedade.

Como resultado dessa influência sobre a liquidez de uma economia e sua capacidade de investimento e crescimento, a atividade bancária, a despeito de exercida por agentes privados, tem sofrido intervenção estatal em diversos países, com diferentes graus e propósitos. Além da intervenção direta por meio de bancos públicos e bancos de desenvolvimento competindo diretamente com os agentes privados, a atividade bancária tem sido objeto de intervenção do estado por meio tanto da política monetária e creditícia quanto da regulação financeira. 
Tanto a política monetária quanto a regulação financeira relacionam-se diretamente com o controle da liquidez da economia. Por meio de instrumentos de ação diversos, o estado procura controlar o volume de crédito gerado pelos bancos, ponderando entre a necessidade de extensão do volume de crédito para incremento do consumo e das atividades produtivas em relação à capacidade de absorção da expansão da base monetária pelo sistema econômico, verificando os impactos dessa expansão sobre o nível de preços. Além disso, o estado pode também procurar influenciar a alocação do crédito financeiro pelas instituições financeiras e o nível de risco que cada instituição bancária individualmente pode assumir em suas operações, dado o descasamento entre ativo e passivo.

Essas atribuições são destinadas, em geral, à autoridade monetária, ou seja, a um ente público que se dedica ao controle da base monetária e das instituições bancárias, cujas ações, repita-se, impactam diretamente sobre essa base ${ }^{47}$. A autoridade monetária tem como foco principal o controle da liquidez da economia, ou seja, da quantidade de moeda (seja escritural ou física) disponível para que os indivíduos se invistam da situação de liquidez e passem, em função disso, a poder atuar nos mercados adquirindo bens ou serviços. Como se passa a discutir, a autoridade monetária tem sido, usualmente, exercida por bancos centrais.

\subsection{Formação dos bancos centrais e a assunção do papel de autoridade monetária}

A autoridade monetária não é necessariamente o Banco Central; essa identidade não é necessária, podendo haver uma série de instituições - ou mesmo nenhuma disciplinando a estrutura monetária e financeira de um país. No entanto, essa identificação é sim muito comum. Observando a experiência de diversos países, é possível notar a atribuição a um banco central da função de controle da liquidez.

Os primeiros bancos centrais eram bancos comerciais com um caráter especial. Eles não eram, como usualmente se vê nos dias de hoje, instituições públicas sem fins

47 Geraldo Camargo Vidigal utiliza a expressão "órgão de direção monetária" na tese de livre-docência Disciplina dos órgãos de direção monetária, Faculdade de Direito da USP, São Paulo, 1964. 
lucrativos, mas sim instituições privadas às quais eram concedidos certos privilégios pelos governos, como a condição de principal banco do governo e, muitas vezes, o monopólio sobre a emissão de moeda.

Nesse período, entre 1668 e 1873, o estabelecimento de bancos comerciais com certo grau de independência sobre a emissão de moeda era considerado como uma alternativa para o restabelecimento da estabilidade monetária, dado o contexto de alta inflação gerado em diversos países europeus e nos EUA pela emissão desenfreada de moeda pelos governos com o fim de financiar as despesas enfrentadas durante diversas guerras e conflitos enfrentados no período. A estabilidade monetária significava nesse contexto a manutenção da convertibilidade em ouro. Durante a vigência do denominado padrão-ouro, o valor da moeda emitida pelos bancos era expresso em termos de seu "conteúdo" em metal, sendo o ouro uma âncora nominal mais relevante que o poder de compra da moeda em relação a bens disponíveis nos mercados.

Inicialmente, essas instituições ainda não podiam ser identificadas com o conceito moderno de banco central, já que atuavam diretamente no mercado concorrendo com os bancos comerciais e não atuavam como supervisores dessas instituições. As tabelas abaixo evidenciam a evolução temporal dos primeiros bancos, evidenciando as datas em que passaram a desempenhar funções típicas de um banco central, como a de monopolista na emissão de moeda e de emprestador de última instância: 
TABELA I - EVOLUÇÃO DOS BANCOS CENTRAIS ANTES DE $1900^{48}$

\begin{tabular}{|c|c|c|c|}
\hline Banco & Fundação & $\begin{array}{c}\text { Monopólio da } \\
\text { emissão de moeda }\end{array}$ & $\begin{array}{c}\text { Empestador de } \\
\text { última instância }\end{array}$ \\
\hline Riksbank Sueco & 1668 & 1897 & 1890 \\
\hline Banco da Inglaterra & 1694 & 1844 & 1870 \\
\hline Banco da França & 1800 & 1848 & 1880 \\
\hline Banco da Finlândia & 1811 & 1886 & 1890 \\
\hline Banco Holandês & 1814 & 1863 & 1870 \\
\hline Banco Nacional da & 1816 & 1816 & 1870 \\
Áustria & & & 1880 \\
\hline Banco Norueguês & 1816 & 1818 & 1870 \\
\hline Banco Dinamarquês & 1818 & 1818 & 1850 \\
\hline Banco de Portugal & 1846 & 1888 & 1880 \\
\hline Banco Nacional Belga & 1850 & 1850 & 1880 \\
\hline Reichsbank (Alemanha) & 1876 & 1876 & 1880 \\
\hline Banco do Japão & 1882 & 1883 & \\
\hline Banco da Itália & 1893 & 1926 & \\
\hline
\end{tabular}

TABELA II - EVOLUÇÃO DO NÚMERO DE BANCOS CENTRAIS ${ }^{49}$

\begin{tabular}{|c|c|}
\hline Década & $\begin{array}{c}\text { Número de bancos } \\
\text { centrais }\end{array}$ \\
\hline $\mathbf{1 9 0 0}$ & 18 \\
\hline $\mathbf{1 9 1 0}$ & 20 \\
\hline $\mathbf{1 9 2 0}$ & 23 \\
\hline $\mathbf{1 9 3 0}$ & 34 \\
\hline $\mathbf{1 9 4 0}$ & 41 \\
\hline $\mathbf{1 9 5 0}$ & 59 \\
\hline $\mathbf{1 9 6 0}$ & 80 \\
\hline $\mathbf{1 9 7 0}$ & 108 \\
\hline $\mathbf{1 9 8 0}$ & 137 \\
\hline $\mathbf{1 9 9 0}$ & 161 \\
\hline
\end{tabular}

\footnotetext{
${ }^{48}$ Tabela extraída e adaptada de Forrest Carpie, Charles Goodhart e Norbert Shnadt, The developmet of central banking, in Forrest Carpie et al, The future of central banking, Cambridge: University Press, 1994, p. 6.

${ }^{49}$ Ibidem, p. 6
} 
Essa atuação no sentido de preservação da convertibilidade da moeda foi desde o início contraposta a uma tensão quanto à função atribuída aos bancos centrais de banqueiro do governo. Os privilégios concedidos a bancos comerciais escolhidos pelos governos como seus bancos exigiam, em retribuição, que os bancos assumissem papel central no financiamento dos déficits orçamentários dos governos:

\begin{abstract}
"There has been an inherent tension throughout the history of central banks between their desire for maintaining the value of their currency and their function as banker to the (central) government. Central banks have almost invariably been established by an Act of government (e.g. a government charter), and have been designated as banker to the government. Governments have a natural preference for cheap finance from their own bank, and, particularly, when the existence of the state is threatened, notably by war, they have both the power and the incentive to force the central bank to give priority to their immediate needs. ${ }^{50}$
\end{abstract}

As guerras enfrentadas pelos países europeus no século XIX e depois a Primeira Guerra Mundial tiveram um papel relevante na definição da atuação dos bancos centrais. Os governos recorreram a esses bancos para a obtenção de recursos que financiassem os imensuráveis gastos do período. Essa exigência de financiamento pelos governos minou o comprometimento dos bancos centrais com a estabilidade monetária e com seu significado naquele período, a convertibilidade para o ouro. Diante dessa incapacidade de manutenção da convertibilidade, os governos foram obrigados a suspender a convertibilidade para o ouro em diversos momentos, instituindo o curso forçado da moeda.

A instituição do curso forçado da moeda não era vista, inicialmente, como uma demonstração de força do sistema de emissão de moeda pelo banco central. Naquela época, o curso forçado significava o enfraquecimento da moeda emitida pelo banco, que deixava de ser "tão boa quanto o ouro ou a prata". No entanto, a despeito de uma inicial desconfiança, a instituição do curso forçado da moeda emitida pelo banco central incentivou um gradual incremento de sua primazia em relação aos demais bancos comerciais, levando-os a aceitarem títulos do banco central para o pagamento de dívidas ou para fins de reserva ${ }^{51}$. Dessa forma, os bancos centrais consolidaram seu papel entre os bancos comerciais como o "banco dos bancos":

\footnotetext{
${ }^{50}$ Ibidem, p. 2.

${ }^{51}$ Ibidem, p. 8.
} 


\begin{abstract}
"Once such Central Banks had been established, however, their central position within the system, their "political" power as the government's bank, their command (usually) over the bulk of the nation's metallic reserve, and, most important, their ability to provide extra cash, notes, by rediscounting made them become the banker's bank: commercial banks would not only hold a large proportion of their own (cash) reserves as balances with the Central Bank, but also rely on it to provide extra liquidity when in difficulties." ${ }^{52}$
\end{abstract}

Neste momento, a evolução natural das atividades dos bancos centrais levou a maioria deles a abandonar suas atividades comerciais, deixando de competir com os demais bancos para que sua liderança frente ao sistema bancário fosse consolidada. Portanto, ainda que os bancos centrais não tivessem sido criados com o fim de supervisionar a atuação dos demais bancos, sua posição fundamental no sistema em função dos privilégios governamentais instituídos os levaram a concentrar reservas dos demais bancos e se tornar banco dos bancos ${ }^{53}$.

Assim, desenvolveram-se as duas dimensões de sua atuação no controle monetário, uma de caráter macro, relacionada ao controle da base monetária, procurando equilibrar a estabilidade de preços com a necessidade de crescimento da economia e geração de empregos, e outra relativa à preservação da higidez das instituições que compõem o sistema financeiro, vista, em geral, como de caráter mais micro, mas que tem clara preocupação de manutenção do sistema como um todo. Havia uma terceira dimensão relacionada ao financiamento das despesas estatais, procurando controlar o mal-uso dos poderes financeiros do Estado e seus impactos sobre a estabilidade de preços.

A relação entre essas três dimensões se alterou consideravelmente ao longo dos anos, sendo possível a identificação de três grandes períodos em que os focos dos diferentes bancos centrais no mundo todo foram marcados elementos comuns ${ }^{54}$.

\footnotetext{
${ }^{52}$ Charles Goodhart, The Evolution of Central Banks, Cambridge: MIT Press, 1988, p. 5.

${ }^{53}$ Bancos criados em período posterior, a partir da primeira década do século XX, como o Federal Reserve System (1913) e o Swiss National Bank (1905), ou que tenham sido criados desde o começo como instituições públicas, como o Reichsbank (1875), foram desenhados desde o início como instituições sem fins lucrativos e que não competiriam com bancos comerciais. Dessa forma, assunção do papel central de regulador e supervisor se deu para eles de modo ainda mais natural (Ibidem, p.9).

${ }^{54}$ Charles Goodhart, The Changing Role of Central Banks, LSE Financial Market Groups Paper Series 197, 2010, p. 3.
} 
A consolidação dos bancos centrais no fim do século XIX e início do XX caracterizou-se pela preocupação com a manutenção da convertibilidade da moeda em ouro e manutenção da estabilidade financeira em períodos de pânico e crise, em que a convertibilidade era suspensa em razão da impossibilidade de sua sustentação em face das volumosas despesas com guerras. Nesse período, o principal instrumento dos bancos centrais era a taxa de juros, controlada por meio de descontos de títulos e por nascentes operações de open market.

Com a erupção da Primeira Guerra Mundial, o sistema bancário enfrentava problemas graves quanto à sua solvência: a depreciação dos ativos localizados em países aliados em função da guerra somada à incapacidade dos bancos de exigir o pagamento de dívidas de residentes domiciliados em países hostis resultou num estado de insolvência das principais instituições bancárias, notadamente daquelas localizadas na City londrina. Nesse contexto, além da intensificação da intervenção direta sobre as instituições bancárias, os bancos centrais passaram a priorizar o financiamento dos déficits dos governos em face da guerra. A convertibilidade para o ouro foi suspensa e o curso forçado instituído, enquanto o aumento das despesas levava a um incremento da taxa de juros e da inflação.

Esse período foi seguido por incrementos do déficit público e hiperinflação em países como a Alemanha, o colapso do comércio internacional em razão da Grande Depressão e medidas impopulares nos EUA e na Inglaterra de manutenção de altos níveis de desemprego e taxa de juros. Esse contexto resultou na extinção do padrão ouro, significando a total falha dos bancos centrais, derrubando seus objetivos, modelos e parâmetros $^{55}$, o que foi acompanhado ainda por uma descrença sobre a capacidade dos mercados de se autogovernarem.

Seguiu-se então uma onda de maior intervenção dos governos, priorizando o incremento das taxas de crescimento e manutenção de altos níveis de emprego, que passaram a ser objetivos dos bancos centrais. Dessa forma, "in practice, the central bank became a junior branch of the Treasury" ${ }^{\prime \prime 6}$.

\footnotetext{
${ }^{55}$ Charles Goodhart, The Changing Role of Central Banks, op. cit., p. 6.

${ }^{56}$ Forrest Carpie, Charles Goodhart e Norbert Shnadt, The developmet of central banking, op. cit., p. 24.
} 
O direcionamento da ação pública para controle da demanda e manutenção de altas taxas de emprego, inclusive com largo uso dos instrumentos de política monetária para esses fins, foi acompanhado do incremento anual dos preços, gerando um processo inflacionário tão intenso que o nível de emprego passava a ser decrescente ("stagflation”), subvertendo a curva de Phillips ${ }^{57}$.

Como resultado, a política monetária voltou-se ao controle de preços, fazendo da estabilidade seu único objeto e deixando a outras políticas econômicas (como a política fiscal ou a industrial) o papel de incrementar o nível produtivo, a taxa de emprego e o crescimento $^{58}$.

Por sua vez, o papel de fiscalização e regulação do sistema financeiro também era proclamado como limitado à garantia da estabilidade financeira e, durante muito tempo, foi relegado a um plano secundário. A intervenção direta pelos governos sobre as atividades produtivas e sobre a política monetária nos pós Segunda Guerra havia sido acompanhada por um movimento concentracionista, que procurava reduzir a concorrência no setor bancário e tornar os bancos mais sólidos e com menos necessidade de enfrentar riscos.

No entanto, o desenvolvimento das telecomunicações havia encurtado a distância entre os países e, como consequência, levado a competição a um nível global. Além disso, o desenvolvimento de um mercado interbancário incrementou a capacidade dos bancos de incrementar sua base disponível para empréstimos, antes limitada à base de depósitos do próprio banco. Como resultado, as reservas de capital dos bancos diminuíram rapidamente, e a interconexão entre os bancos no interbancário tornava o sistema muito frágil e sujeito aos riscos de contágio já debatidos.

Esse cenário chegou próximo de seu limite quando, diante do incremento das taxas de juros pelo FED americano, os países importadores de petróleo se viram impossibilitados de arcar com suas dívidas, levando Brasil, Argentina e México a ameaçarem decretar moratória. Mesmo sem que isso se concretizasse, os ativos detidos pelos bancos americanos que vinham emprestando valores crescentes a esses países perderam tanto

\footnotetext{
57 A relação entre emprego e inflação será examinada à frente, no item 2.4 , assim como o significado da curva de Phillips.

${ }^{58}$ Forrest Carpie, Charles Goodhart e Norbert Shnadt, The developmet of central banking, op.cit., p.29.
} 
valor que muitos deles se tornaram insolventes. Esse contexto fez com que o Congresso norte-americano pressionasse o FED a incrementar o nível de regulamentação e supervisão das instituições financeiras. Os americanos pressionaram então o Comitê de Supervisão Bancária da Basiléia para que fosse convencionado um padrão mundial para reservas mínimas de capital pelos bancos. Em 1988, o Acordo de Basiléia I foi editado, sendo depois complementado por Basiléia II.

Depreende-se que a política monetária e a regulação das instituições bancárias tornaram-se as atividades principais dos bancos centrais, que assumiram como propósitos fundamentais - e muitas vezes exclusivo - a manutenção da estabilidade de preços e da estabilidade financeira.

\title{
2.3. O controle da liquidez pelos bancos centrais: política monetária e regulação
}

Os bancos centrais têm desempenhado essencialmente duas funções relacionadas ao controle da liquidez da economia, que se influenciam mutuamente ${ }^{59}$ :

\begin{abstract}
"Central banks have two main interrelated functions, first the macrofunction of maintaining nominal price stability and second the microfunction of ensuring the healthy development of the payments, banking and financial systems. The functions are interrelated because the stability of the banking system will be threatened by high and volatile inflation, while the price mechanism in turn is likely to be disturbed by booms and bust, especially systemic crises, in the payment and banking systems, and perhaps within the wider financial system as well." ${ }^{60}$
\end{abstract}

A ampliação do volume de crédito e, por consequência, da base monetária têm sido objeto de controle pelo Estado por meio da política monetária. Os instrumentos dessa política têm como um de seus papéis principais impedir o descontrole da expansão da base monetária, procurando garantir um equilíbrio entre a estabilidade de preços e a demanda de moeda para expansão das atividades produtivas e geração de emprego. A política

\footnotetext{
59 A autoridade pública responsável pela política monetária não é, em determinados países, a mesma encarregada da regulação financeira. No entanto, dada a reiterada concentração das duas funções em uma só autoridade, o banco central, a análise neste trabalho assume essa concentração.

${ }^{60}$ Maxwell J. Fry, Charles Goodhart e Alvaro Almeida, Central Banking in Developing Countries, London: Routledge, 1996, p. 79.
} 
monetária é exercida pelo banco central por meio de ajustes em seu balanço, que influenciam diretamente na constituição da base monetária disponível.

Simplificando a composição do balanço de um banco central, há, do lado do passivo, as moedas em circulação emitidas pelo banco e as reservas nele depositadas pelas instituições financeiras em razão de regras de depósito compulsório. Como ativos, o banco detém títulos da dívida pública e títulos obtidos em razão de operações de redesconto feitas pelo banco. Emissões de moeda ou diminuições das reservas exigidas das instituições financeiras, sem que sejam alterados os componentes do ativo, incrementam a base monetária. Do mesmo modo, recompra de títulos da dívida pública pelo banco central ou incentivos a um maior uso do redesconto mediante reduções na taxa cobrada, também resultam em expansão da base monetária disponível (formada pelas reservas e pelo dinheiro em circulação) ${ }^{61}$.

O contrário também se aplica: aumento das reservas exigidas dos bancos comerciais, venda de títulos públicos ou incremento da taxa cobrada pelo redesconto resultarão numa diminuição da base monetária. Portanto, alterações no balaço entre ativo e passivo do banco central resultam em modificações diretas na base monetária disponível. A partir dessa dinâmica, o banco central procura interferir sobre os mercados controlando a liquidez da economia, incentivando ou inibindo que os agentes possam exercer em maior ou menor volume as posições de liquidez adquirindo bens. Os principais mecanismos de execução da política monetária são:

Reservas (depósitos) compulsórias - estipula-se que determinada parcela dos valores detidos pelos bancos comerciais em razão das atividades de intermediação financeira deve ser mantida em depósito no banco central, afetando assim o volume de capitais em poder dos bancos e sua capacidade de multiplicação.

Redesconto bancário - são operações de assistência financeira de liquidez realizadas por meio de empréstimos pelo banco central, na forma de crédito em reservas bancárias, para atender necessidades de liquidez de bancos comerciais. Pode se dar por meio de empréstimos com garantias ou por meio de redescontos de

${ }^{61}$ A respeito ver Frederic S. Mishkin, The Economics of Money, Banking and Financial Markets, 7. ed., Addison Wesley, 2004, pp. 358-62. 
títulos previamente eleitos pelo banco central, sendo, em geral, títulos da dívida pública (o que fomenta a demanda dos bancos por esses títulos).

Operações de "open market" - As operações de mercado aberto funcionam por meio da compra e venda de títulos públicos pelo banco central, impactando diretamente o volume de reservas bancárias e, por consequência, o multiplicador monetário. Ao comprar títulos, o banco central faz mais capital ingressar na economia, enquanto que a venda de títulos pelo banco central contrai o volume de capital disponível.

As operações de open market são o instrumento mais relevante de política monetária, pois constrangem diretamente a base monetária, além de permitirem ajustes no rumo da política de modo mais rápido ${ }^{62}$. Por isso, a tendência internacional é no sentido de utilizar esse instrumento em larga escala para implementação da política monetária.

Além disso, essas operações são utilizadas também para sinalizar a taxa de juros básica: "Nessas operações, o sinal do rumo da política é enviado por intermédio da divulgação da taxa de juros pela qual foram negociados os títulos ou reservas entre o Banco Central e o mercado. ${ }^{163}$

A política monetária visa influenciar o nível da taxa de juros de curto prazo (o que claramente afeta o volume de financiamento e a disponibilidade financeira) através da mudança nas ofertas de reservas bancárias:

\footnotetext{
${ }^{62}$ Ibidem, p. 398. Ao analisar o caso norte-americano, esse autor explica elementos relevantes das operações de mercado aberto: "open market operations have several advantages over the other tools of monetary policy: 1. Open market operations occur at the initiative of the FED, which has complete control over their volume. This control is not found, for example, in discount operations, in which the FED can encourage or discourage banks to take out discount loans by altering the discount rate but cannot directly control the volume discount loans. 2. Open market operations are flexible and precise, they can be used to any extent. No matter how small a change in reserves or the monetary base is desired, open market operations can achieve with a small purchase or sale of securities. Conversely, if the desired change in reserves or the base is very large, the open market operations tool is strong enough to do the job through a very large purchase or sale of securities. 3. Open market operations are easily reversed. If a mistake is made in conducting an open market operation, the FED can immediately reverse it. If the FED decides that the federal funds rate is too low because it has made too many open market purchases, it can immediately make a correction by conducting open market sales. 4. Open market operations can be implemented quickly; they involve no administrative delays. When the FED decides that it wants to change the monetary base or reserves, it just places orders with securities dealers, and the trades are executed immediately." (Ibidem, p. 400).

${ }^{63}$ Fernando J. Cardim de Carvalho et. al, Economia Monetária e Financeira: teoria e política, 2. ed., Rio de Janeiro: Elsevier, 2007, p. 177.
} 


\begin{abstract}
"A taxa de juros de curto prazo, ou taxa básica da economia, nada mais é que o resultado do confronto entre a oferta de reservas, definida pelas atuações do Banco Central nas operações compromissadas e operações definitivas e o saldo do fluxo de entrada e de saída de dinheiro para e do sistema bancário, com a demanda por reservas dessas instituições definida pelas suas necessidades de atender às exigibilidades compulsórias e seus compromissos com o setor não-monetário da economia.

(....) Com base nessas metas, e levando em consideração suas estimativas para a evolução autônoma das reservas, o Banco Central toma suas decisões de expandir ou contrair a oferta de reservas de modo a atender seus objetivos de curto, médio e longo prazo para a taxa de juros. Para a autoridade monetária, as metas de juros atuam enquanto metas operacionais para atender seus objetivos no que se refere a inflação e/ou produto e emprego." ${ }^{64}$
\end{abstract}

A taxa de juros básica influencia os juros cobrados pelos bancos na concessão de crédito a indivíduos ou empresas. Desse modo, quanto mais alta a taxa de juros básica, mais altos os juros cobrados pelos bancos para operações no mercado de crédito, o que impacta diretamente o papel do crédito no desenvolvimento. Afinal, juros muito altos podem inviabilizar projetos importantes, dado o incremento do custo total que representam, e reduzir a demanda por bens. Uma política de juros altos procura, em geral, conter uma tendência inflacionária, mas tem efeitos colaterais relevantes: sufoca a demanda e as atividades produtivas, incrementando o nível de desemprego.

Além disso, como a taxa básica é o referencial para o pagamento de juros pelos títulos da dívida pública, um incremento dessa taxa significa também maior endividamento do Estado e diminuição de sua capacidade de investimento. Existe também um efeito deletério sobre a taxa de câmbio, já que juros altos podem atrair capitais estrangeiros, aumentando o volume de divisas no país e valorizando a moeda nacional e tornando as exportações menos competitivas, afetando o saldo da balança comercial.

O papel eminentemente central das operações de open market e de definição da taxa de juros reverbera sobre as funções dos demais instrumentos de política monetária. Tanto o redesconto quanto o recolhimento compulsório passam a ter papel secundário na política monetária e assumem, reversamente, papéis importantes para a garantia de liquidez ao sistema bancário, diminuindo a probabilidade de crises financeiras, e também para o

\footnotetext{
${ }^{64}$ Ibidem, pp. 193-4.
} 
controle da alocação do crédito pelas instituições bancárias, influenciando as condições de concessão de crédito por essas instituições. Dessa forma, esses instrumentos mantêm papel de destaque na regulação do sistema bancário.

A justificativa econômica tradicional para a regulação bancária está primariamente relacionada à manutenção da higidez do sistema financeiro, e emerge, como destacado acima, a partir da peculiar composição estrutural dos bancos e da interconexão existente entre eles por meio do sistema de pagamentos.

Isso porque existe um descasamento entre o ativo e o passivo dos bancos, uma vez que seu patrimônio é constituído por débitos exigíveis à vista em grande parte, enquanto seus créditos são integrados pelos empréstimos feitos pelos bancos, na grande maioria das vezes exigíveis a prazos mais dilatados. Essa constituição patrimonial dos bancos significa que tais instituições podem ter seus débitos exigidos a qualquer tempo, enquanto seus créditos não o são. Além disso, os bancos não mantêm em suas reservas todos os valores depositados na instituição, mas apenas uma pequena parcela desses depósitos, partindo da suposição de que seus clientes não necessitam de volumes substantivos de papel moeda para suas despesas. Por isso, mantêm apenas quantias mínimas para que possam atender as necessidades normais de liquidez dos clientes.

Como resultado, caso todos os depositantes decidam sacar os valores depositados ao mesmo tempo, qualquer banco se tornaria insolvente. Esse contexto torna as instituições bancárias vulneráveis a crises de confiança. Essas crises são muito temidas porque podem resultar em corridas bancárias: caso haja suspeita sobre a solvabilidade de um banco, os depositantes podem decidir sacar os valores depositados por temerem que o banco não tenha capacidade de honrar seus compromissos.

Essa fragilidade de cada instituição bancária individualmente é agravada pela interdependência existente entre as instituições. Os bancos necessariamente mantêm relações de crédito entre si, para compensações de pagamentos realizados por meio do sistema de pagamento ou mesmo pela realização de empréstimos interbancários. Essas relações entre os bancos originam o chamado risco sistêmico: a quebra de uma instituição pode causar dificuldades generalizadas em outras instituições, podendo resultar na quebra 
também dessas outras instituições. Em outras palavras, um evento independente, a quebra de uma instituição, pode gerar a quebra de outras.

O risco sistêmico está subordinado à verificação de um evento sistêmico, que se compõe por um acontecimento gerador deste, denominado de "choque", e por mecanismos capazes de propagá-lo ("mecanismos de propagação") 65 . Os choques podem ser acontecimentos como a quebra de uma ou mais instituições ou a divulgação de informações sobre a situação patrimonial dessas instituições. Esses acontecimentos podem, pelos mecanismos de propagação, afetar outras instituições financeiras que tenham relações com aquelas afetadas no primeiro momento.

Um dos principais mecanismos de propagação de choques no sistema bancário é a exposição real entre os bancos. As instituições bancárias se relacionam entre si para fazer compensações e transferências entre instituições originadas das relações organizadas pelo sistema de pagamentos e para o controle de liquidez das instituições, através do mercado interbancário, à medida que um banco pode financiar a necessidade de liquidez de outro. Dessa forma, caso um banco deixe de ser capaz de honrar seus compromissos, ele pode levar o sistema de pagamentos a colapso em razão da não compensação dos títulos por ele detidos, expondo os demais bancos à situação de insolvência.

Além disso, o descasamento entre ativo e passivo e a assimetria de informações existentes entre os bancos e seus clientes podem transformar uma crise de confiança em uma corrida bancária, uma vez que a crise de uma instituição bancária pode abalar a confiança em todo o sistema de garantir a liquidez dos depósitos. Portanto, a estrutura patrimonial dos bancos e a alta assimetria informacional dos clientes intensificam os possíveis mecanismos de propagação de um eventual choque, capaz de desencadear um evento sistêmico.

Uma crise bancária pode ter consequências muito severas sobre a economia. A escassez de recursos para investimentos e a insegurança no ambiente de negócios é apenas um passo inicial da crise. As características peculiares do sistema bancário implicam numa capacidade de impactar diretamente o regime monetário e a capacidade da moeda de servir

\footnotetext{
${ }^{65}$ Cf. Olivier de Bandt e Philipp Hartmann, Systemic Risk: a Survey, op. cit., p. 10.
} 
com instrumento de troca, padrão e reserva de valor. Dessa forma, o agravamento da crise bancária pode resultar na quebra da confiança no padrão monetário, impactando os padrões produtivos e a capacidade de desenvolvimento da sociedade, já que, numa economia monetária, todo o sistema de contratos está pautado pela moeda e suas funções.

Dessa forma, a regulação bancária procura influenciar o nível de risco a ser suportado pelas instituições financeiras em sua atividade, tendo em vista a proteção dos investidores e do sistema como um todo. Assim, costuma ser justificada a partir de três objetivos principais: (i) a manutenção da estabilidade sistêmica; (ii) a garantia da segurança e do bom funcionamento das instituições financeiras; e (iii) a proteção do consumidor.

Nesse sentido, desenvolvem-se no sistema bancário precipuamente dois tipos de regulação, a prudencial e a sistêmica:

\begin{abstract}
"Prudential and systemic regulation need to be distinguished, although both adopt a similar approach. Systemic regulation is about the safety and soundness of financial institutions for purely systemic reason (i.e. because the social costs of the failure of an institution exceed the private costs). On the other hand, prudential regulation is about the safety and soundness of financial institutions vis-à-vis consumer protection, in that the consumer loses when an institution fails, even if there are no systemic consequences." ${ }^{16}$
\end{abstract}

A regulação prudencial constitui um mecanismo de regulação apriorístico, que procura garantir a higidez do sistema bancário e contrabalançar a incapacidade dos depositantes de aferirem a situação patrimonial dos bancos, numa relação em que a substantiva assimetria informacional dá lugar a um risco moral substantivo: "the case for prudential regulation and supervision is that consumers are not in a position to judge the safety and soundness of financial institutions ${ }^{\prime \prime 67}$.

Portanto, essa modalidade de regulação procura essencialmente proteger os interesses dos depositantes, criando limites à exposição das instituições bancárias a riscos, por meio de mecanismos como aprovação de entrada de novos bancos ou de operações societárias entre eles, fixação de requisitos de capital mínimo com base nos ativos e o nível

${ }^{66}$ Charles Goodhart et al., Financial Regulation: Why, How and Where Now?, Routledge, 1998, p. 5.

${ }^{67}$ Ibidem, p. 5. 
de risco, estabelecimento dos depósitos compulsórios ou operações de redesconto, já destacados, e outros.

Esses mecanismos são acompanhados por ferramentas de monitoramento (fiscalização) dos bancos comerciais atribuída a um órgão com capacidade de análise da situação dos bancos, para que possam ser examinadas as condutas e inibidas ações que possam lesar os interesses dos correntistas.

Além da proteção dos consumidores, ao procurar preservar instituições bancárias individualmente, a regulação prudencial contribui subsidiariamente à manutenção da normalidade no sistema como um todo.

Por outro lado, a regulação sistêmica objetiva principalmente evitar uma crise bancária. Trata-se de um conjunto de técnicas regulatórias de caráter emergencial, implementadas a partir da verificação de um evento sistêmico com o fim de evitar uma crise sistêmica e garantir a manutenção da estabilidade financeira.

Os principais mecanismos de intervenção utilizados pelas autoridades monetárias são seguro de depósito (funciona como uma garantia aos correntistas de um banco, à medida que assegura o pagamento de parte ou do total dos depósitos feitos em um determinado banco) ${ }^{68}$, a atuação do Banco Central como empestador de última instância ou hipóteses de intervenção direta para gerenciamento de bancos em crise.

\subsection{Intervenção sobre a atividade bancária: o coro pela limitação}

A observação da atuação dos Estados a partir da Segunda Guerra Mundial revela intensa intervenção sobre o sistema bancário. Essa fase de forte ativismo teve início na

\footnotetext{
${ }^{68}$ No Brasil, existe o Fundo Garantidor de Créditos (FGC), que visa garantir o crédito dos depositantes até o limite de $\mathrm{R} \$ 60.000,00$ por depósitos em um mesmo conglomerado financeiro. Mais informações podem ser obtidas no sito eletrônico do BCB (www.bcb.org.br) ou no sítio eletrônico do próprio fundo (www.fgc.org.br).
} 
década de 30, em reação à Grande Depressão, e se intensificou após a Segunda Guerra Mundial, com a emergência do Estado social em substituição do Estado liberal.

Mesmo nos países desenvolvidos, os bancos eram sujeitos a um controle rígido por parte dos governos, o que se justificava tanto pela necessidade de garantia da estabilidade financeira quanto pelo papel central dos bancos no processo de desenvolvimento ${ }^{69}$. Dessa forma, é importante destacar que a atuação dos Estados sobre o sistema financeiro já refletia preocupações com a estabilidade financeira, especialmente diante da crise enfrentada em 1929. Por isso, funções como o empestador de última instância do banco central se consolidaram nesse período.

As políticas estatais de intervenção no sistema bancário compreendiam também aspectos de desenvolvimento que ultrapassavam a questão da estabilidade. Nesse sentido, era possível observar tanto nos países desenvolvidos quanto naqueles em desenvolvimento o largo uso de instrumentos de política monetária, direcionamento de crédito, bancos públicos e da própria regulação bancária como instrumentos que integram o contexto de uma política de desenvolvimento (ainda que não haja um expresso reconhecimento dessa finalidade ou mesmo a clara e formal elaboração de uma política de desenvolvimento).

Ao analisar especificamente a atuação dos bancos centrais, Gerald Epstein ratifica a percepção de que ao longo da história a intervenção do Estado sobre o sistema financeiro tinha como uma de suas finalidades o desenvolvimento. Após um exame das experiências dos bancos centrais de diversos países, ele relata que a atuação dessas instituições compreendia a utilização de diversos mecanismos de controle do fluxo de capitais estrangeiros, de política monetária e de regulação bancária (como, por exemplo, mecanismos de direcionamento de crédito) como instrumentos de uma política de desenvolvimento.

Mesmo em países como os Estados Unidos e a Inglaterra, porta-vozes inflamados do discurso contra essa atuação, os bancos centrais tiveram papel relevante e atuaram sobre a economia não só para manutenção da estabilidade, mas também desenvolvendo políticas de crédito e alocando recursos. Isso ganha ainda maior amplitude em países como a

\footnotetext{
${ }^{69}$ Cf. Barbara Stallings e Rogerio Studart, Finance for Development, op. cit., p. 22.
} 
França, em que o banco central tinha papel vital na política industrial, e nos países em desenvolvimento, em que os bancos centrais constituíam agentes do desenvolvimento ${ }^{70}$.

De fato, com a extinção do padrão-ouro, o Estado deixou de olhar, na condução da política monetária, unicamente para a conversibilidade e manutenção da estabilidade de preços, passando a ponderar também outros objetivos. O manejo da moeda passou a ser vista como um dos instrumentos de política econômica à disposição do Estado, exigindo sua coordenação com a política de crédito, fiscal e industrial.

Essa alteração na ação dos Estados assumia que era possível reduzir o desemprego e fomentar as atividades produtivas em troca de um incremento no nível de preços. Em outras palavras, um certo nível de inflação poderia ser aceitável para o incremento do nível de emprego e da produção.

Tal concepção baseava-se na denominada curva de Phillips, conforme seu exame e desdobramentos na análise de Paul Samuelson e Robert Solow. Num artigo eminentemente empírico publicado em 1958, W. Phillips utilizou dados históricos da Grã-Bretanha (18611913) para traçar um gráfico que evidenciava que quando o desemprego era alto, os salários permaneciam em patamares também baixos.

A partir desse trabalho, Paul Samuleson e Robert Solow, utilizando dados de 1900 a 1960, repetiram o mesmo exercício para os Estados Unidos, alterando, no entanto, a relação analisada: ao invés de relacionar desemprego e nível de salários, relacionaram inflação e desemprego. Eles publicaram o resultado de sua pesquisa em 1960 e batizaram a relação estudada de curva de Phillips, cuja inclinação negativa indicava que um aumento do nível de desemprego poderia eliminar ou moderar o aumento de preços ${ }^{71}$.

A partir dessa conclusão, a política monetária dos países passou a procurar alcançar uma relação ótima entre inflação e nível de emprego. Seria possível suportar um certo nível de inflação com o fim de aumentar a liquidez na economia e estimular a demanda

\footnotetext{
${ }^{70}$ Cf. Gerald Epstein, Central Banks as Agents of Economic Development, in Ha-Joon Chang (org.), Institutional Change and Economic Development, United Nation University Press, 2008, p. 101.

${ }^{71}$ Para uma exposição detalhada da evolução da curva de Phillips ver Fernando J. Cardim de Carvalho et. al, Economia Monetária e Financeira: teoria e política, op. cit., pp. 136-8.
} 
agregada, aumentando, consequentemente, a taxa de emprego e o crescimento da economia. Existiria, portanto, um dilema (trade-off) de escolha para a sociedade entre um nível de desemprego e um nível de inflação, sendo possível que os governos escolhessem um patamar de posicionamento nesse dilema ${ }^{72}$.

Assim, assumia-se que os governos seriam capazes de determinar um ponto na curva de Phillips onde posicionar suas economias e nele se manter. Essa regra de política monetária foi adotada pelos países desenvolvidos na década de 1960. Nos Estados Unidos, por exemplo, Samuelson e Solow, hoje conhecidos como autores velho-keynesianos, aconselharam o governo americano a alcançar um desemprego de 4\% ao ano, que seria, para eles, consistente com uma taxa de inflação de 3\%. A administração Kennedy anunciou em 1962 uma meta de 4\% de desemprego, que passou a constituir, por sua repetida discussão em diversos meios jornalísticos e acadêmicos, a meta de pleno emprego.

Goodhart sumariza a concepção vigente na década de 1960 e o revés presenciado na década seguinte, com o fenômeno da estagflação:

\begin{abstract}
"This suggested that the authorities might be able to choose an optimal combination, or trade-off, between inflation and unemployment. And this is exactly what governments sought to do in the 1950s and 1960s. But by the 1970s, the rate of inflation consistent with a given level of unemployment kept on rising, we ran into stagflation." ${ }^{73}$
\end{abstract}

Na década de 1970, a relação entre desemprego e inflação que havia se confirmado na década anterior despareceu. Nesse período, verificou-se um aumento contínuo das taxas de inflação acompanhado de aumento no nível de desemprego, caracterizando o que ficou conhecido como estagflação - estagnação econômica acompanhada de altas taxas inflacionárias.

Observando a estagflação da economia americana, Milton Friedman argumentou que, como os agentes econômicos já não tinham expectativas de que os preços se manteriam inalterados, alguma taxa de inflação passou a integrar a expectativa dos agentes,

${ }^{72}$ Cf. Robert Leigh-Pemberton, The Case for Price Stability, in Bank of England Quarterly Bulletin 32 (1992), p. 442.

${ }^{73}$ Charles Goodhart, Central Bank Independence, Special Paper 57, London: London School of Economics, 1993, p. 2. 
que passaram a fazer seus cálculos incluindo a inflação esperada, incrementando assim os salários, lucros e preços ajustados nas relações contratuais. Assim, as expectativas racionais dos agentes econômicos eliminavam o dilema (trade-off) entre inflação e nível de desemprego no longo prazo (a curva de Phillips era, na verdade, vertical) ${ }^{74}$.

Essa teoria quantitativa da moeda alcançou a condição de ortodoxia econômica, sendo replicada e aceita por diversos teóricos, que procuram qualificá-la como um consenso em matéria econômica. Seus postulados baseiam-se na premissa de neutralidade da moeda no longo prazo, ou seja, os fenômenos monetários não podem afetar o desempenho da economia real e suas variáveis como nível de produção e emprego pelo menos no longo prazo (ainda que monetaristas mais extremados defendam a neutralidade também no curto prazo), enquanto que a inflação seria um fenômeno eminentemente monetário. Nas palavras de Milton Friedman:

\begin{abstract}
"We have accepted the quantity-theory presumption, and have thought it supported by the evidence we examined, that changes in the quantity of money as such in the long run have a negligible effect on real income, so that nonmonetary forces are 'all that matter' for changes in real income over the decades and money 'does not matter". ${ }^{75}$
\end{abstract}

É nesse contexto e alicerçada na teoria quantitativa da moeda que a estabilidade de preços alcançou o status de objetivo central da política monetária, e os bancos centrais assumiram um papel de destaque na política econômica dos Estados como responsáveis por reduzir e, posteriormente, eliminar, os males trazidos pela inflação:

\footnotetext{
"All those rationalizations became less and less persuasive as basic economic performance - growth, employment and productivity - seemed to deteriorate in the face of high and accelerating inflation. Exchange markets were unstable and a speculative atmosphere in many markets heightened the sense of foreboding.

In those circumstances, the monetarist refrain that inflation is, after all, in the end a monetary phenomenon struck an increasingly responsive chord among the body politic. In effect, central banks began to have a stronger platform for effective action." ${ }^{76}$
}

\footnotetext{
74 "Far from there being any exploitable trade-off in the medium and longer term between inflation and higher output levels, the accepted view now is that in the longer term this relationship is negative, i.e., more inflation is associated with lower growth." (Maxwell J. Fry, Charles Goodhart e Alvaro Almeida, Central Banking in Developing Countries, op. cit., p. 14).

75 A theoretical framework for monetary analysis, in A. A. Walters (org.), Money and Banking, Harmondsworth: Penguin, 1973, p. 82.

${ }^{76}$ Paul A. Volcker, The Triumph of Central Banking?, Washington: International Monetary Fund, 1990, p. 5.
} 
Dado que o processo inflacionário é difícil de ser contido e tem consequências muito graves sobre o nível de investimento e a capacidade de crescimento de uma sociedade, a garantia da estabilidade de preços deveria ser o principal foco - se não o único - dos bancos centrais na execução da política monetária. Dessa forma, a contribuição dos bancos centrais para o desenvolvimento econômico restaria unicamente na manutenção de um ambiente macroeconômico estável.

Essa concepção sobre o papel da política monetária foi corroborada não só por teóricos, mas por dirigentes dos bancos centrais de diversos países. É interessante anotar o pronunciamento de alguns deles, como o do então dirigente (governor) do Banco da Inglaterra:

\begin{abstract}
"But, as the Government has made clear, it does not imply any change at all in the ultimate objective of monetary policy - price stability not simply as an end in itself, but as a necessary condition for stable growth of output and employment. ${ }^{177}$
\end{abstract}

Paul Volcker, que dirigiu o Federal Reserve americano entre as décadas de 1970 e 1980, reforça a concepção de que a estabilidade monetária é objetivo central da política monetária. Em uma conferência organizada pelo Banco Popular da China, o Fundo Monetário Internacional (FMI) e o Programa das Nações Unidas para o Desenvolvimento (PNUD), em Beijing, China, em 1990, Volcker enfatizou que, ainda que outros objetivos sejam também atribuídos à política monetária, como pleno emprego, crescimento, etc, eles seriam apenas secundários e, em geral, de responsabilidade de outras políticas econômicas do Estado. A política monetária, deveria, conforme preconizado por Volcker, concentrar-se na estabilidade monetária: "A point that I would like to emphasize is that monetary stability is the first priority of monetary policy, and, when there is a choice of objectives, that is the one that should be emphasized." 78

Assim, a atual "receita" de melhores práticas internacionais nos últimos 20 anos, a partir de reflexões neoliberais, preconiza como papel dos bancos centrais unicamente a manutenção da estabilidade macroeconômica, refutando a história e a tradição dos bancos

\footnotetext{
${ }^{77}$ Robert Leigh-Pemberton, The Case for Price Stability, op. cit., p. 441.

78 Paul A. Volcher, Role of Monetary Policy, in Paul A. Volcker, Miguel Mancera e Jean Godeaux, Perspectives on the Role of a Central Bank, Washington: International Monetary Fund, 1991, p. 13.
} 
centrais em todo o mundo de intervenção no contexto da política de desenvolvimento do Estado.

Essa constatação pode se estender também às demais formas de intervenção do estado sobre o sistema financeiro. Afinal, a despeito da extensa atuação dos Estados sobre o sistema financeiro tendo em vista aspectos atrelados ao desenvolvimento, as principais teorias econômicas, apontadas nos últimos 20 anos como best practice internacional, preconizam uma intervenção limitada como a melhor forma de se gerar desenvolvimento.

Segundo a visão amplamente difundida na literatura econômica ("mainstream"), a intervenção do Estado sobre o sistema bancário não deve lançar mão de instrumentos como direcionamento de crédito, bancos públicos, controle de capitais estrangeiros e, reitere-se, direcionar sua política monetária segundo interesses desenvolvimentistas. Essa atuação, ao interferir no livre jogo do mercado, seria ineficiente do ponto de vista econômico e geraria, reversamente, menores níveis de desenvolvimento.

Portanto, em contraposição à experiência de diversos países, desenvolvidos ou em desenvolvimento, a teoria econômica mais difundida, ou, em submissão ao anglicismo comumente utilizado, o "mainstream" das teorias econômicas, aponta para a necessidade de se limitar a atuação dos Estados sobre o sistema financeiro como condição para que seja efetivamente promovido o desenvolvimento econômico. A garantia do equilíbrio do sistema financeiro e da estabilidade macroeconômica seriam os únicos propósitos atribuíveis ao Estado, que deveria ser dotado de ferramentas limitadas de intervenção. Assegurada essa esfera de estabilidade, os agentes econômicos agiriam de modo racional, levando o sistema a um ponto de equilíbrio eficiente, em que os recursos fluiriam livremente e os melhores projetos receberiam recursos para investimento.

Por isso, preconiza essa concepção que a intervenção do Estado deveria limitar-se a corrigir falhas de mercado, garantindo a estabilidade macroeconômica, por meio $(i)$ da regulação financeira, com o fim específico de manutenção da estabilidade sistêmica, protegendo os investidores e a higidez do $\operatorname{sistema~}^{79}$; $(\mathrm{ii})$ de uma política monetária que vise

\footnotetext{
${ }^{79}$ Nesse contexto, os objetivos da regulação bancária, conforme preconizado por diversos autores e autoridades reguladoras, diz respeito à definição do risco a ser suportado pelas instituições financeiras em sua atividade, tendo em vista a proteção dos investidores e do sistema como um todo. Assim, costuma ser
} 
exclusivamente a estabilidade macroeconômica e controle da inflação ${ }^{80}$; (iii) do fomento da concorrência entre os agentes, o que levaria a uma situação eficiente do ponto de vista econômico; e (iv) da melhoria das instituições jurídicas pertinentes aos contratos de crédito, mediante, por exemplo, o aperfeiçoamento de institutos contratuais, instituições judiciárias e formas de coerção civil, desenvolvendo o que se convencionou denominar dotação institucional ${ }^{81}$; e (v) da redução ou total eliminação da participação de bancos públicos $^{82}$.

Dessa forma, cumpriria ao Estado unicamente garantir e facilitar o livre jogo dos agentes no mercado e um ambiente macroeconômico estável. A livre concorrência e a estabilidade financeira constituiriam assim condições necessárias e suficientes para o desenvolvimento financeiro, cabendo a outras políticas (como a fiscal ou industrial) o incentivo às atividades produtivas ou redistribuição de riquezas.

justificada a partir de três objetivos principais: (i) a manutenção da estabilidade sistêmica; (ii) a garantia da segurança e do bom funcionamento das instituições financeiras; e (iii) a proteção do consumidor.

Nesse sentido, desenvolvem-se no sistema bancário precipuamente dois tipos de regulação: a prudencial e a sistêmica. A regulação prudencial constitui um mecanismo de regulação apriorístico, que procura garantir a higidez do sistema bancário através da supressão da incapacidade dos depositantes de aferirem a situação patrimonial dos bancos. Portanto, procura essencialmente proteger os interesses dos depositantes, criando limites à exposição das instituições bancárias a riscos, o que contribui subsidiariamente à manutenção da normalidade no sistema. A respeito ver Charles Goodhart et al., Financial Regulation: Why, How and Where Now?, op. cit., 1998.

${ }^{80} \mathrm{O}$ ex-presidente do Banco Central Armínio Fraga destaca a necessidade de que o Banco Central se concentre unicamente em manter a estabilidade macroeconômica (O papel do Banco Central no século 21, In Revista de Direito Bancário e do Mercado de Capitais, v.2, n.6 (1999), pp. 21-3.

${ }^{81}$ Uma das mais importantes referências dessa literatura encontra-se em Rafael La Porta, Florencio Lopezde-Silanes, Andreu Shleifer e Robert W. Vishny, Law and Finance, Working Paper 5661, Cambridge, Mass: National Burreau of Economicsm, 1996 e Rafael La Porta et al., Legal Determinants of External Finance, in Journal of Finance 52 (1997), pp. 1131-50. No caso do Brasil, o Banco Central tem procurado incentivar a evolução da dotação institucional do país no que diz respeito ao cumprimento de contratos de crédito, procurando, dessa forma, fomentar a concessão de crédito no país; nesse sentido ver o interessante trabalho de Emerson Ribeiro Fabiani, Reformas institucionais do mercado de crédito bancário no Brasil (1999-2006): uma análise jus-sociológica, Tese de Doutorado, Universidade de São Paulo, 2009.

${ }^{82}$ Note-se uma boa síntese do argumento contra a perpetuação de bancos públicos: "In the recent wave of literature on finance and growth, by contrast, state-owned financial institutions have come under heavy attack. The principal theoretical argument against them is the alleged political motive behind lending, as opposed to the developmental or social motives that dominated the earlier analyses. This argument is closely related to the rent-seeking critiques of the state role in the economy more generally... Given such motives, credit is likely to fund inefficient projects, which - even if they are actually carried out - will have low rates of return at the microeconomic level and undermine productivity and growth at the macroeconomic level."(Barbara Stallings e Rogerio Studart, Finance for Development, op. cit., p. 55). Essa crítica é reforçada por estudos empíricos que procuram demonstrar que países com menor taxas de crescimento têm bancos públicos, como o estudo de Rafael La Porta, Florencio López-de-Silanes e Andrei Shleifer, Government Ownership of Banks in Journal of Finance 57 (2002), pp.265-301. Referências relevantes sobre o tema podem também ser encontradas em Gerard Caprio et. al (org.), The Future of State-Owned Financial Institutions, Washington: Brookings Institution, 2004. Especificamente sobre o caso brasileiro, ver Armando Castelar Pinheiro, Bancos públicos no Brasil: para onde ir?, in Armando Castelar Pinheiro e Luiz C. de Oliveira Filho, Mercado de capitais e bancos públicos - análise e experiências comparadas, Rio de Janeiro/São Paulo: Contra-Capa/ANBID, 2007, pp. 159-264. 


\subsection{Autonomia e cientifização: da despolitização à apolitização e o problema da accountability}

No contexto de difusão dessa ortodoxia econômica, verifica-se cada vez mais uma preocupação por parte dos Estados em se adequar a esse paradigma e limitar suas presenças no sistema financeiro. Essa auto-limitação é inclusive incentivada por organismos internacionais como o Banco Mundial e o Fundo Monetário Internacional, que condicionam a concessão de crédito ao cumprimento pelos países de uma série de regras formuladas a partir desse entendimento e à consecução dos parâmetros por a partir dele estabelecidos.

As crises inflacionárias enfrentadas na década de 1980 em razão essencialmente de abusos cometidos na gestão da moeda fizeram com que autoridades monetárias de vários países passassem a apostar com maior vigor na percepção de que a estabilidade macroeconômica deveria ser o principal - muitas vezes único - objetivo da atuação do Estado sobre o setor bancário, tanto na elaboração da política monetária quanto da regulação financeira.

Esse movimento foi acompanhado e também justificou a promoção de reformas nas legislações de diversos países ou mudanças informais nas relações entre organizações dos governos com o fim de conferir maior autonomia aos bancos centrais ${ }^{83}$. Diante dos abusos cometidos pelos governos na gestão da política monetária, resultando no processo de hiperinflação vivenciados na década de 1980, a ideia de um órgão técnico e autônomo para implementação da política monetária ganhou força.

O estabelecimento de bancos centrais autônomos seria assim um remédio contra a inconsistência temporal da ação política, influenciada pelos possíveis ganhos de curto

\footnotetext{
${ }^{83}$ Neste trabalho os termos autonomia e independência são tratados como intercambiáveis. Existem autores, no entanto, que defendem e necessidade de diferenciar independência de autonomia. Dentre eles, Jairo Saddi aponta que o conceito de independência é mais amplo que o de autonomia, e significaria o estabelecimento de um quarto poder do Estado ao lado do Executivo, do Legislativo e do Judiciário (Jairo Saddi, O poder e o cofre - repensando o banco central, São Paulo: TextoNovo, 1997, p. 53).
} 
prazo com o imposto inflacionário. Políticos teriam dificuldades em estabelecer planos de longo prazo em razão de seus interesses eleitorais de curto prazo; isso criaria um incentivo para estratégias de ações políticas muito pautadas em explorar ganhos de curto prazo. No caso da política monetária, isso resultaria numa provável tentativa pelos políticos de formulá-la considerando unicamente sua influência no curto prazo, procurando assim sopesar ganhos com o processo inflacionário vis-à-vis seus custos, sem considerar, no entanto, os efeitos dessa política no longo prazo ${ }^{84}$.

Nesse sentido, a partir muitas vezes citado artigo de Kydland e Prescott, a autonomia dos bancos centrais passou a ser vista como forma de garantir um compromisso de longo prazo com a estabilidade monetária. Foi preconizado que a supressão da discricionariedade - e possível viés inflacionário - deveria compreender o estabelecimento de uma regra simples e automática de expansão contínua e previsível da base monetária ${ }^{85}$. Essa ideia deu origem ao famoso debate regra versus discricionariedade, em que se contrapunha a previsibilidade de uma regra para a expansão da base monetária à discricionariedade do órgão técnico, banco central, para ajustar a política monetária à luz dos contextos vivenciados, compreendendo e assimilando momentos em que menor rigor pode ser necessário para conter processos de estagnação ou mesmo retração da economia ${ }^{86}$.

Assim, em contraposição à estruturação da política monetária a partir de um raciocínio baseado no cálculo político - que, repita-se, revelaria uma tendência inflacionária -, a proposta que passou a ser aplicada amplamente por muitos países foi a de atribuir o julgamento sobre a estabilidade monetária a um órgão dotado de conhecimento técnico e autônomo, procurando assim evitar sua sujeição a interesses políticos de curto

\footnotetext{
84 "Modern theory attributes the inflationary bias either to the dynamic inconsistency of monetary policy in an expectational Phillips-curve model of output determination or to the revenue motive of the inflation tax, in a context in which the fiscal authority weights the social costs of inflation inappropriately, or to both." (Stanley Fischer, Central Bank Independence Revisited, op. cit., p. 201.)

${ }^{85} \mathrm{O}$ argumento de F. Kydland e E. Prescott aponta, em síntese que "reliance on policies such as a constant growth in the money supply and constant tax rates constitute a safer course of action. When we do have the prerequisite understanding of the business cycle, the implication of our analysis is that policymakers should follow rules rather than have discretion. The reason that they should not have discretion is not that they are stupid or evil but, rather, that discretion implies selecting the decision which is best, given the current situation. Such behavior either results in consistent but suboptimal planning or in economic stability." (Rules rather than discretion: the inconsistency of the optimal plan, in Journal of Political Economy 85 (1977), p. 487).

${ }^{86}$ A formulação econômica deste debate pode ser encontrada em Charles Goodhart, Money, Information and Uncertainty, 2. ed., Cambridge: MIT, 1989, pp. 361 e ss.
} 
prazo (ainda que se reconheça que há interesses individuais dos agentes que podem influenciar as decisões).

Os bancos centrais autônomos seriam então um mecanismo de seguro contra a tendência inflacionária da ação política ${ }^{87}$, embora as evidências empíricas sobre a correlação entre autonomia, estabilidade monetária e crescimento econômico sejam consistentes para países desenvolvidos, mas ainda questionáveis quanto aos países em desenvolvimento ${ }^{88}$.

Os bancos centrais passaram então por um processo de "despolitização", realizada mediante reformas legais ou por meio de alterações informais nas relações entre os órgãos de governo. Como resultado, ganharam autonomia material ou orçamentária (autonomia financeira para se estruturar) e autonomia política, relacionada principalmente aos mecanismos de nomeação e afastamento de membros do órgão. Tal esfera de autonomina procura garantir aos dirigentes capacidade de exercício pleno de seu mandato, sem ingerências ou pressões de outros órgãos do governo. Por fim, há ainda a autonomia econômica, de especial interesse para este trabalho ${ }^{89}$.

A autonomia econômica diz respeito à liberdade para formulação e implementação da política monetária. Stanley Fisher distingue entre autonomia de metas (goal independence) da autonomia operacional (instrument independence) ${ }^{90}$. O grau de autonomia dos bancos centrais pode variar da autonomia econômica completa, hipótese em que o banco define seus fins e instrumentos (instrument e goal independence), para hipóteses mais limitadas de autonomia, em que os fins do banco central são definidos aprioristicamente no plano político, restando-lhe total ou parcial autonomia de meios para formulação e implementação dos instrumentos que visam atingir os objetivos previamente definidos.

\footnotetext{
87 Jon Elster compara a autonomia dos bancos centrais ao desenvolvimento das cortes constitucionais, apontando que ambas as instituições procuram reduzir a inconsistência temporal da ação política (Constitutional Courts and Central Banks: Suicide Prevention or Suicide Pact?, East European Constitutional Review, n. 3 (1994), p. 68).

${ }^{88}$ Uma série de outras questões influencia a verificação dessa correlação em países em desenvolvimento, inclusive, uma identificada "cultura inflacionária". Uma síntese dos estudos empíricos sobre essa relação de causalidade pode ser encontrada em Stanley Fisher, Modern Approach to Central Banking, NBER Working Paper n. 5064, 1995, pp. 44-51.

89 A distinção entre autonomia financeira, política e econômica baseia-se em Luis Jácome, Legal Central Bank Independence and Inflation in Latin America During the 1990s, IMF Working Paper, 2001, pp. 8-9.

${ }^{90}$ Stanley Fischer, Modern Approach to Central Banking, op. cit., p. 40.
} 
Em consonância com o ideal democrático, a maior parte dos bancos centrais conta apenas com independência de meios, sendo seus fins estabelecidos previamente, em geral, por legislação aprovada pelo Parlamento. O estabelecimento de fins pelo Parlamento, implica na necessidade de sua observação pelos bancos centrais, que devem então ser fiscalizados e responderem pela escolha de instrumentos operacionais que se distanciem desses fins. A questão da responsabilização" ("accountability", na terminologia em inglês amplamente adotada na doutrina) é fundamental neste ponto:

\begin{abstract}
"The most important conclusion of both the theoretical and empirical literatures is that a central bank should have instrument independence, but should not have goal independence. Rather, the central bank should be given a clearly defined goal or set of goals, and the power to achieve them, and should be held accountable for doing so. Accountability is needed for two reasons: first, to set incentives for the central bank to meet its goals and explain its actions; and second, to provide democratic oversight of a powerful political institution. ${ }^{, 92}$
\end{abstract}

A accountability constitui uma espécie de antídoto contra o remédio que pode se mostrar mais grave que a doença: a autonomia de bancos centrais pode levar o insulamento em relação ao governo e ao parlamento a um extremo perigoso. Na metáfora de Elster, a accountability é o mecanismo que pode permitir que os bancos centrais se mantenham como "suicide prevention" (em relação à citada inconsistência temporal e ganhos com imposto inflacionário) e não se transformem em "suicide pact" $"$.

O debate sobre accountability deve compreender não apenas a estrutura de normas formais ou informais relacionadas a deveres de transparência, justificação de decisões e responsabilização, elementos que têm sido recentemente debatidos com maior proeminência, mas deve envolver também o estabelecimento, significado e abrangência das escolhas políticas externadas por meio de regras jurídicas sobre os fins e instrumentos da atuação da burocracia.

\footnotetext{
91 A tradução de "accountability" como "responsabilização" é baseada em Jean Paul Veiga da Rocha, Autonomia e accountability no sistema financeiro: notas para uma agenda de pesquisa jurídica, in Revista de Direito Público da Economia 33 (2011), p. 109.

${ }^{92}$ Stanley Fischer, Central Bank Independence Revisited, op. cit., p. 202.

${ }^{93}$ Cf. Jon Elster, Constitutional Courts and Central Banks: Suicide Prevention or Suicide Pact?, op. cit., p. 66.
} 
Em recente tese de doutorado, Camila Villard Durand argumenta que “(...) $a$ principal função do Direito como instrumento de regulação monetária está na institucionalização de mecanismos jurídicos de supervisão (e, consequentemente, de transparência), prestação de contas e sanção de bancos centrais - ou seja, essencialmente regras de avaliação e julgamento ex post da tomada de decisão, ainda que elas envolvam a definição a priori de metas e objetivos. "94 Embora a autora esteja correta ao enfatizar a função ex post de avaliação, a definição ex ante de metas e objetivos é papel fundamental do Direito, que deve influenciar substantivamente - e não apenas procedimentalmente - a formulação da regulação monetária (aqui entendida como compreendendo política monetária e regulação financeira).

Nesse ponto, é importante destacar que os ordenamentos jurídicos de diversos países, inclusive do Brasil, estabelecem objetivos para a regulação monetária, e atribuem papéis específicos para as organizações do Estado. O ordenamento jurídico contém assim uma série de normas que requerem um exame interdisciplinar, envolvendo juristas e economistas num diálogo próximo, para se definir com clareza os objetivos e parâmetros para ação dos bancos centrais. Essa atividade ex ante é, inclusive, pressuposto para a avaliação ex post, já que lhe estabelece parâmetros. Nesse sentido, não se pode limitar o papel do Direito à definição de processos e procedimentos de análise. A dogmática jurídica é parte também da dimensão substantiva de análise, definição, implementação e avaliação da regulação monetária ${ }^{95}$.

A ênfase no papel substantivo do Direito torna-se ainda mais relevante à medida que a literatura econômica tem ignorado as disposições dos ordenamentos jurídicos nacionais, como se a autoridade monetária devesse pautar seus atos unicamente por teorias e não pela dogmática jurídica. Isso se reflete também na ação dos bancos centrais, sendo

\footnotetext{
${ }^{94}$ Camila Villard Duran, A moldura juridical da política monetária - um estudo de caso, Tese de Doutorado, Faculdade de Direito da Universidade de São Paulo, 2012, p. 65.

${ }^{95}$ Camila Duran, posteriormente, termina por reconhecer esse papel do direito, a despeito de enfatizar, em minha avaliação de sua tese como um todo, o papel procedimental do direito. O trecho a seguir é ilustrativo do reconhecimento da complementaridade entre os papéis do direito no estabelecimento de mecanismos procedimentais de acesso à informação e contestação pública e do papel do direito na conformação da própria regulação monetária: “O direito tende a expor o processo decisório da política monetária, bem como seus resultados, e a abrir caminhos institucionais de contestação pública. Ele institui mecanismos de referência para a supervisão, como a definição de metas e objetivos a serem atingidos, e que, posteriormente, servem como padrão de avaliação de resultados." (Ibidem, p. 66).
} 
possível se identificar um processo de alegada cientificização das escolhas dessas instituições, o que as tornaria apolíticas:

\begin{abstract}
“ 'Scientization' is a reform process that goes beyond autonomization. It signifies a shift in authoritative status. Scientized bureaucratic agencies do not only base their legitimacy on delegated, rational-legal or moral authority. Scientization implies that public agencies are being endowed with scientific authority. Through scientization, central banks is to an increasing extent being framed in apolitical terms. Thus, scientization of central bankers implies that central banking is in many ways transcending formal politics. Below, a number of indicators are listed that support the claim that central banking has not only been depolitized, through a process of autonomization; it has been apoliticized through scientization and, consequently, it may be about to leave the official political game altogether." ${ }^{96}$
\end{abstract}

O processo de despolitização é distinto da cientificização. A despolitização compreendia essencialmente a garantia de maior autonomia aos bancos centrais, que como agentes técnicos e não sujeitos diretamente ao cálculo político tomariam decisões desprovidas de paixões e mais consistentes no longo prazo. Esse processo não significava, no entanto, uma negação do caráter político das escolhas quanto à regulação monetária. Escolhas estatais nessas questões são eminentemente políticas por compreenderem opções sobre preferências e preteridos. A autonomia e despolitização procuravam apenas subtrair essas decisões de políticos eleitos, agregando assim elementos técnicos à decisão e procurando minimizar os problemas de inconsistência temporal. Dessa forma, as escolhas (e preferências) de dirigentes não eleitos permaneceriam sujeitas a controle externo e responsabilização, e os políticos se consideravam parte desse processo, dialogando e expondo perspectivas aos burocratas. Nesse contexto, recaem sobre o burocrata os ônus de transparência e de justificação de suas decisões, que devem ser fundamentadas à luz dos objetivos previamente estabelecidos por meio de regras jurídicas no plano político ${ }^{97}$.

\footnotetext{
${ }^{96}$ Martin Marcussen, Institutional Transformation? The Scientization of Central Banking as a Case Study, op. cit., p. 82

97 Nesse sentido, Martin Marcussen esclarece que: "Scientization which apoliticizes the art of central banking is fundamentally different from autonomization which depoliticizes central banking. Autonomous central banking does not imply that media and politicians and other opinion-makers do not care about or pay attention to the métier of central bankers, but scientization does. Autonomous central banking does not imply that central bankers automatically are considered to be right when they make decisions, scientization does. And autonomization does not imply that central bankers are being uncritically listened to as the Delphi oracle, even when they speak out about matters that lie far beyond the narrow filed of monetary and financial policy, but scientization does." (The Fifth Age of Central Banking in the Global Economy, Working Paper Frontiers of Regulation, 2006, p. 9.
} 
O alegado consenso sobre a teoria econômica aplicável aos bancos centrais e a integração entre banco central e academia, com a nomeação de dirigentes e corpos técnicos que participavam ou passam a participar do processo de construção do conhecimento científico na área, dá lugar ao processo de cientificização: bancos centrais passam a se ver e serem vistos como cientistas, como indivíduos que aplicam uma ciência exata e complexa, por isso, difícil de ser questionada. A atividade dos bancos centrais seria então assunto de alçada exclusiva de intelectuais com sólida formação econômica, em relação à qual políticos eleitos não deveriam nem mesmo se aproximar.

A cientificização se verifica em diversos âmbitos e pode ter três consequências que merecem especial destaque.

Primeiro, bancos centrais passaram a criar e a financiar ciência. São estabelecidos grupos de estudos, séries de trabalhos internos, publicações de revistas científicas, programas de financiamento de bolsas, contratação de indivíduos com alta qualificação e professores para formação de grupos técnicos, e que depois passam a disseminar o conhecimento ali formulado quando voltam a seus postos originais. Como resultado, a produção de conhecimento científico tem sido influenciada por eles; significa dizer que, dado que os recursos despendidos pelos bancos centrais com pesquisas são muito extensos em comparação com outras fontes, essas instituições passam a ditar em larga medida a agenda de pesquisa científica na área econômica e influenciar quais discussões merecem destaque e quais devem ser esquecidas, favorecendo assim a perpetuação da ortodoxia ("mainstream" ) que preconiza a limitação do papel dos bancos centrais à garantia da estabilidade. Logo, "if central bank stability-oriented ideas about sound money, finances and institutions tend to have achieved a status of hegemony, this status can only be expected to be further consolidated by additional funding in its favour $" 98$.

Segundo, a cientificização implica na desconsideração de particularidades locais, numa governança supostamente pautada no conhecimento. Teorias pretensamente aplicáveis universalmente (one-size-fits-all) ganham força, o que é corroborado pela

\footnotetext{
${ }^{98}$ Martin Marcussen, Institutional Transformation? The Scientization of Central Banking as a Case Study, op. cit., p. 101.
} 
intensificação do diálogo e cooperação internacional, tanto por meio de acordos de cooperação entre instituições ou comunidades epistêmicas (redes de profissionais com expertise em determinada área que compartilham determinadas crenças e reivindicam a si próprios a autoridade sobre o conhecimento de determinada área). As decisões são tomadas com base em teorias e modelos alegadamente científicos, ignorando, muitas vezes, o arcabouço legal e as particularidades sociais e históricas de determinados países ou regiões.

Por fim, há consequências relevantes sobre a accountability. O processo de cientificização leva a uma alegada apolitização da ação de bancos centrais, posto que as decisões são alegadamente científicas, ou seja, mais confiáveis pois não pautadas em escolhas políticas e sim postulados científicos, o que torna seu questionamento mais difícil e limita os indivíduos considerados capazes de tal questionamento a membros da comunidade científica, e não mais políticos ou atores de mercado:

\begin{abstract}
"In the area of central banking this means that monetary policy is becoming apoliticized and thus acquiring the status of a scientific discipline which aspires to transcending politics. The entire area of policy-making has now become separated from the day-today business of politics and no longer has a place in the hearts and minds of ordinary politicians. Whereas before, national politicians almost always had opinions about interest rates and the level of inflation (even if they did not make them public), the new tendency may be that they no longer give any consideration to these aspects of macro-economic policy or to their practical implications." $" 99$
\end{abstract}

Assim, as autoridades monetárias teriam sido desumanizadas e absolutamente privadas de ideologias pessoais. A crença na cientificidade de suas decisões pode passar a ser a base de sua legitimidade para a elaboração da regulação monetária: dado que cientificidade está ligada a uma ideia de credibilidade e veracidade, suas decisões passam a ser apresentadas com as únicas possíveis e corretas ou, na metáfora de Marcussen, o banco central passa a ser um oráculo ${ }^{100}$. A cientificização traz assim obstáculos à accountability:

\footnotetext{
${ }^{99}$ Ibidem, p. 104.

100 "To be clear, scientization does not imply that the 'art of central banking' is somehow becoming increasingly 'efficient', 'effective', or 'rational'. The classical central bank culture is still based on a pragmatic, inductive approach to problem solving. Decisions made by central bankers can probably best be described as negotiated compromises and not as outcomes of some scientific, deductive analysis. Rather, scientization should be understood as a way of boosting the legitimacy and the external status of the central bank in question. Through the authority that is attributed to experts, central bankers can consolidate their powerful position in the national and transnational economic fields." (Ibidem, p. 104.)
} 
afinal, quem pode questionar a ciência? Políticos com interesses eleitorais ou juízes não versados em ciência econômica?

\subsection{Autoridade monetária e desenvolvimento: estabilidade de preços e financeira como únicos papéis?}

O papel "minimalista"atribuído pela atual ortodoxia econômica à autoridade monetária limita seu papel à garantia da estabilidade de preços e da higidez das instituições financeiras. Dentro dessa concepção, a autoridade monetária contribui para o desenvolvimento econômico por meio da garantia da estabilidade. Portanto, a autoridade monetária não poderia ter - dado, enfatize-se, a neutralidade da moeda sobre a economia real no longo prazo - um papel transformador, uma atuação ativa no sentido de fomentar o desenvolvimento econômico à redução de desigualdades.

Como destacado acima, essa "receita" de melhores práticas tem sido adotada por diversos bancos centrais nas últimas duas décadas. Essas autoridades monetárias passaram a limitar seus papéis dentro da política de desenvolvimento do país à garantia da estabilidade de preços. Os bancos centrais têm sustentado a existência de um consenso constituído pela teoria econômica e pela prática de bancos centrais em países desenvolvidos - sobre a necessidade de que o papel da autoridade monetária seja limitado à garantia da estabilidade macroeconômica. Esse consenso estaria assentado em bases científicas e, por isso, encerraria conclusões possivelmente mais adequadas. A partir disso, os instrumentos de política monetária e a ação dos bancos centrais estariam também se desenvolvendo sobre bases científicas. Nesse contexto, a ideia de autonomia dos bancos centrais ganha força e se entrelaça com a concepção ortodoxa acerca do papel do banco central. O discurso da autonomia fica impregnado pela concepção de que o banco central tem como único papel garantir a estabilidade monetária. Em outras palavras, a autonomia seria condição para a estabilidade, e só se fala em autonomia se o que se pretende é exclusivamente a estabilidade. 
Contudo, a dispersão acentuada dessa concepção por diversos países e sua aceitação acrítica - num processo aqui denominado de apolitização - pode ser muito problemática, por três razões principais.

Inicialmente, a teoria econômica que embasa essa concepção está longe de ser um consenso. Na verdade, existem diversas críticas e questionamentos ao postulado de neutralidade da moeda e diversas evidências empíricas indicam a importância da moeda para o desempenho das economias, inclusive no longo prazo. A ciência econômica é muita aberta a contestações e postulados efetivamente sólidos são raros. Por isso, é necessário um debate mais extenso entre a ortodoxia e as teorias ditas heterodoxas, dentre elas o póskeynesianismo, para que elementos de cada uma das teorias sejam combinados para soluções projetadas e testadas para contextos e cenários específicos ${ }^{101}$.

Outra razão relevante e relacionada a essa primeira é a necessidade de se considerar a realidade de cada nação separadamente. A concepção hoje dominante foi formulada principalmente por teóricos que consideravam a realidade de países desenvolvidos e está sendo difundida como receita universal (one-size-fits-all). Embora já exista alguma literatura que procura examinar especificamente sua aplicabilidade a países em desenvolvimento $^{102}$, é necessário distinguir as condições econômicas e demandas específicas de países como Estados Unidos e Alemanha (onde a limitação da autoridade monetária à garantia da estabilidade vige com força) de países como o Brasil, Chile ou Índia:

\footnotetext{
${ }^{101}$ O Professor Titular de Economia da Universidade Federal do Rio de Janeiro, Fernando Carvalho, expõe esse ponto com precisão: "Ao contrário da visão convencional, que focaliza apenas a disponibilidade de meios de pagamento e que, por isso mesmo, julga que um banco central deve voltar-se apenas para o comportamento dos preços de bens e serviços, já que sua influência sobre variáveis reais é, no máximo, temporária, economistas keynesianos ressaltam os efeitos da política monetária sobre os preços dos ativos e, desse modo, os efeitos reais duradouros dessas políticas sobre o investimento real e o produto. Em resultado, dois quase-consensos correntes são recusados: 1. um banco central não pode se "especializar" em perseguir metas nominais, como as metas inflacionárias, porque sua política impactará também variáveis reais, e não apenas no curto termo; 2. como a ação da autoridade monetária tem impactos potencialmente divergentes sobre a taxa de inflação e sobre o produto (e sobre o investimento real), a decisão de fixação da taxa de juros não é puramente "técnica", mas é também intrínseca e inevitavelmente política, porque envolve julgamento não apenas de meios, mas também de fins (por exemplo, favorecendo mais a estabilidade de preços que o crescimento econômico); por essa razão, o banco central não deve ser independente, mesmo na versão atenuada que propõe a "autonomia de instrumentos". É exatamente o "instrumento" que importa, a determinação da taxa de juros, pois é ela que poderá afetar preços, mas também investimento e produto." (Uma contribuição ao debate em torno da eficácia da política monetária e algumas implicações para o caso do Brasil, in Revista de Economia Política, vol. 25, n.4 (2005), pp. 327328).

${ }^{102}$ Para um estudo comparativo com uma amostra de diversos países em desenvolvimento ver Maxwell J. Fry, Charles Goodhart e Alvaro Almeida, Central Banking in Developing Countries, op.cit., pp. 15 e ss.
} 
"Esta opção pode ter alguma lógica em países industrializados desenvolvidos, econômica e politicamente estabilizados. Mas parece dificilmente aceitável em países que têm no desenvolvimento econômico o principal problema a resolver (e nos quais, em regra, a administração fiscal é deficiente e o mercado monetário e o mercado financeiro não existem ou não funcionam), bem como em países com situações difíceis no domínio do emprego e da balança de pagamentos.

Nestes últimos casos, parece desejável que o banco central, enquanto autoridade monetária, não possa alhear-se da situação econômica e social do país, erigindo a estabilidade monetária em objetivo primordial de sua acção, ao qual deverão sacrificar-se, friamente, os outros objetivos da política econômica (o crescimento econômico, a modernização da estrutura produtiva, a modificação da estrutura do comércio externo, os investimentos estratégicos na educação, na saúde, na segurança social, etc.)." 103

O terceiro elemento relevante a ser considerado é que mesmo as autoridades monetárias dotadas de autonomia estão inseridas no contexto da política de desenvolvimento do Estado, permanecendo sujeita ao ordenamento jurídico de cada país. Significa dizer que suas escolhas são sim políticas, pois encerram a determinação de preferência e preteridos: “a política monetária é uma política de governo. O Banco Central não é um poder à parte, nem é capaz de isolar sua área de influência das outras áreas da economia" ${ }^{\prime 104}$.

Por essa razão, a autoridade monetária tem, em geral, seus objetivos e instrumentos disciplinados pelo ordenamento jurídico, que consubstancia escolhas políticas de órgãos cuja legitimidade democrática emana de sua origem no voto popular, seja o Parlamento ou o Executivo. Além disso, a própria definição da autoridade monetária e a divisão de atribuições com outros órgãos do Estado, disciplinada pelo ordenamento jurídico, devem influenciar a análise.

Nesse contexto, o discurso da autonomia não deve estar necessariamente relacionado à noção de estabilidade como único objeto da autoridade monetária ${ }^{105}$. O

\footnotetext{
103 António José Avelãs Nunes, Nota sobre a independência dos bancos centrais, in Revista de Direito Mercantil, Industrial, Econômico e Financeiro 103 (1996), p. 65.

${ }^{104}$ Fernando Cardim Carvalho, Uma contribuição ao debate em torno da eficácia da política monetária e algumas implicações para o caso do Brasil, op. cit., p. 335.

${ }^{105}$ Nesse sentido, "não tem fundamento a tese dos que pretendem que a noção de independência dos bancos centrais só faz sentido a partir do reconhecimento de que a inflação é essencialmente um fenômeno monetário e de que o único objectivo da política monetária prosseguir sem qualquer consideração pelos
} 
banco central pode ter autonomia de meio para consecução de objetivos previamente definidos no plano político (o que a literatura tem comumente denominado de instrument independence), mas continua, como é evidente, vinculada às metas traçadas pelo ordenamento jurídico (a hipótese contrária seria a de goal independence). Por isso, caso se reconheça a relevância de autonomia da autoridade monetária, para que sua capacidade técnica prevaleça sobre interesses pautados pelo cálculo político de curto prazo, essa autonomia pode estar vinculada a escolhas políticas pretéritas e mais abrangentes do que a pura estabilidade monetária, que foram traçadas e convertidas em normas jurídicas justamente para que as instituições e agentes permanecessem a elas vinculados. Deve-se ter em mente que o direito é um instrumento para garantia de previsibilidade e calculabilidade, também contribuindo para redução da inconsistência temporal ${ }^{106}$.

O ordenamento jurídico não pode ser ignorado, pois é ele que estabelece a divisão de atribuições entre a autoridade monetária e outros órgãos do Estado e confere legitimidade jurídico-formal a seus atos, devendo, necessariamente, ser considerado na formulação das políticas e em sua posterior avaliação. Em outras palavras, o ordenamento estabelece os contornos da ação dos bancos centrais, definindo os objetivos, conferindo os meios para execução e estabelecendo os parâmetros para sua avaliação e responsabilização por outros órgãos (accountability).

Nesse sentido, o Banco Central alemão (Bundesbank), por exemplo, tem, por definição legal, autonomia de instrumentos e tem como único objeto assegurar a estabilidade de preços. Não há qualquer menção a desenvolvimento econômico ou qualquer outra meta. No caso desse país, com a ressalva de não se ter feito um exame detalhado de seu atual contexto, parece mais plausível a defesa da aplicabilidade da ortodoxia econômica. Afinal, além de se tratar de um dos países mais desenvolvidos do mundo, o ordenamento jurídico expressamente limitou o objeto da autoridade monetária à

outros objetivos políticos do estado.” (José António José Avelãs Nunes, Nota sobre a independência dos bancos centrais, op. cit., p. 61).

${ }^{106}$ Fernando Cardim Carvalho aponta que mesmo a autonomia de meios não é aceitável porque é justamente a definição dos meios que impacta os resultados. Por isso, a definição dos instrumentos da política monetária deveria integrar o contexto de definição da política econômica do governo como um todo (Uma contribuição ao debate em torno da eficácia da política monetária e algumas implicações para o caso do Brasil, op. cit., p. 335). Não se pretende aqui discutir se a autonomia de meios é ou não desejável. O que se pretende é deixar claro que mesmo que haja independência de meios, o banco central permanece vinculado aos objetivos previamente estabelecidos pelo direito, não podendo ignorá-los com base no discurso da autonomia e de pretenso cientificismo. 
consecução da estabilidade. No entanto, os ordenamentos jurídicos de outros países atribuem à autoridade monetária, em geral, outros objetivos, estabelecendo, inclusive, ferramentas distintas e uma divisão de atribuições que torne a autoridade monetária mais próxima dos demais órgãos do Estado para coordenação da política de desenvolvimento.

É interessante notar que ordenamentos jurídicos que estabelecem outros objetivos para a autoridade monetária (como o desenvolvimento econômico) têm sido apontados pela literatura econômica como anomalias, sendo os regramentos qualificados como contraditórios posto que estabilidade e desenvolvimento seriam opostos inconciliáveis do ponto de vista monetário. Ou, em tantas outras vezes, a literatura econômica tem simplesmente ignorado as disposições dos ordenamentos jurídicos nacionais, como se a autoridade monetária devesse pautar seus atos unicamente por teorias e não pela dogmática jurídica $^{107}$.

Contudo, o Direito influencia substantivamente - e não apenas procedimentalmente - a formulação da regulação monetária. O ordenamento jurídico contém assim uma série de normas que requerem um exame interdisciplinar, envolvendo juristas e economistas num diálogo próximo, para se definir com clareza os objetivos e parâmetros para ação dos bancos centrais. Essa atividade ex ante é, inclusive, pressuposto para a accoutability ex post, já que lhe estabelece parâmetros. Nesse sentido, não se pode limitar o papel do Direito à definiçãa de processos e procedimentos de análise. A dogmática jurídica é parte também da dimensão substantiva de análise, definição, execução e avaliação da regulação monetária.

Tendo em vista essas três razões para não se aceitar de imediato a receita de atuação proposta pela ortodoxia econômica, esse trabalho pretende evidenciar que há fundamentos tanto de ordem econômica quanto jurídica para que a autoridade monetária não tenha sua atuação limitada à garantia da estabilidade monetária e higidez do sistema financeiro. Tanto a política monetária quanto a regulação bancária devem sopesar elementos relativos à influência do sistema financeiro sobre o desenvolvimento econômico, o que tem sido, em diversos países, refletido pelo ordenamento jurídico.

${ }^{107}$ Exemplo de abordagem deste tipo pode ser encontrada em Alex Cukierman, Steven B. Webb e Bilin Neyapti, Measuring the Independence of Central Banks and its Effects on Policy Outcomes, in The World Bank Economic review, vol. 6, n. 3 (1992), pp. 353-398. 
Dada a complexidade do tema e as diversas nuances a serem consideradas, este trabalho centra-se em um dos aspectos do desenvolvimento econômico: o desenvolvimento regional, que foi, como já anotado, alçado a objeto do Estado brasileiro. Além disso, dadas as diferenças no contexto econômico e no ordenamento jurídico dos diversos países, a análise tem como objeto o caso brasileiro.

No próximo capítulo, procede-se a uma análise dos argumentos econômicos que sustentam a necessidade de intervenção estatal sobre o sistema bancário para fomentar o desenvolvimento regional. Esse capítulo compreende também uma discussão acerca do contexto brasileiro, para que sejam examinadas as evidências empíricas de que existe um problema econômico a ser enfrentado. Por fim, o capítulo 4 debate a disciplina do ordenamento jurídico brasileiro, procurando evidenciar que ele não ratifica a limitação do papel da autoridade monetária à garantia da estabilidade. Como se demonstrará, tanto a Constituição Federal quanto o ordenamento infraconstitucional conferem às autoridades monetárias um papel transformador e enfatizam sua importância no fomento ao desenvolvimento regional.

É importante que se esclareça desde já que este trabalho não pretende negar a importância da estabilidade monetária e do mal que um processo inflacionário acentuado pode causar ao desenvolvimento do país. Como reconhecido anteriormente, a inflação é um problema grave, capaz de prejudicar de modo intenso o desenvolvimento nacional. No entanto, esse trabalho assume que é sim possível sopesar estabilidade com uma ação da autoridade monetária no sentido de fomentar o desenvolvimento.

Isso não significa necessariamente - e como se verá adiante, nem poderia significar, dada a expressa vedação constitucional - financiamento público. A emissão desenfreada de moeda para financiamento da dívida pública certamente não faz parte de uma política séria de desenvolvimento. No entanto, o que deve ficar claro é que o fato de ter havido no passado diversos abusos pelo Poder Executivo quanto à gestão da política monetária, que acabaram levando ao processo de estagflação, não pode fazer com que a importância do sistema bancário para o desenvolvimento do país seja esquecida e que o papel do Estado nesse setor seja totalmente cerceado. É sim necessário que os abusos sejam contidos e que 
as políticas sejam pensadas de modo a ponderar a estabilidade monetária como um dos elementos centrais, porém, não exclusivo.

Dessa forma, o objetivo deste trabalho é demonstrar que o livre jogo do mercado leva, no caso do sistema bancário, à perpetuação da desigualdade regional. Por isso, o Estado deve intervir para que o sistema bancário desempenhe efetivamente sua função enquanto vetor do desenvolvimento econômico, sem, no entanto, descuidar da necessidade de se manter a estabilidade monetária. Existem uma série de ferramentas de política monetária e de regulação bancária com nenhum ou quase nenhum efeito sobre a base monetária e que podem contribuir para que o sistema bancário propicie maior desenvolvimento regional.

Por isso, cabe aos teóricos e àqueles que atuam diretamente no setor abandonar o estado de conformismo quanto ao papel do sistema bancário no desenvolvimento e passar a pensar políticas que, considerando as falhas e abusos do passado, sejam capazes de criar mecanismos institucionais que evitem abusos e que sejam capazes de, sopesando os elementos de teoria econômica, definir uma atuação para o Estado compatível com a dogmática jurídica e o contexto econômico nacional.

No Brasil, como será discutido à frente, identifica-se uma tendência à limitação do papel do Estado, que, a partir de reformas ocorridas principalmente na década de 1990, passou a restringir o papel dos bancos públicos, atenuou a disciplina dos capitais estrangeiros e das atividades financeiras, e passou a balizar a política monetária unicamente para manutenção da estabilidade macroeconômica, relegando o papel central no processo de desenvolvimento atribuído pelo direito à autoridade monetária. 


\section{A QUESTÃO ECONÔMICA E O CONTEXTO NACIONAL: DESENVOLVIMENTO REGIONAL E SISTEMA BANCÁRIO NO BRASIL}

A geografia organizacional e institucional do sistema financeiro influencia seu desempenho. Essa é a premissa de uma série de análises de economistas e geógrafos acerca do desempenho de sistemas financeiros. Para esses autores, o arranjo espacial das instituições e agentes pode resultar em diferentes padrões na circulação e formação da poupança e do crédito financeiro.

Segundo R. Martin, quatro aspectos da organização espacial do sistema determinam o fluxo de recursos pelo espaço: estrutura locacional das instituições financeiras, geografia institucional do sistema, esferas de regulação estatal e esferas de financiamento público ${ }^{108}$.

O primeiro aspecto - estrutura locacional das instituições financeiras - diz respeito ao modo como se arranjam no espaço as instituições financeiras. Embora parte das funções financeiras (como bancos de varejo, operações imobiliárias, etc) alcancem praticamente todas as regiões nas economias com certo grau de desenvolvimento, acompanhando o processo de expansão demográfica, instituições e atividades mais específicas (como bancos de investimento, "venture capital", fundos de pensão, etc) costumam permanecer concentradas em determinadas áreas geográficas.

As atividades financeiras apresentam uma tendência hsitórica de concentração em determinadas localidades, procurando alcançar economias de escala e aglomeração, seguindo um caminho de path dependence que poderia muitas vezes resultar num efeito de retenção ('lock-in”) geográfica. Como resultado, observa-se na maioria dos países a configuração de centros financeiros regionais e de um centro financeiro a nível nacional, que, em alguns casos, constitui também um centro financeiro para um bloco de países ou até mesmo mundial, como nos casos de Nova Iorque e Londres ${ }^{109}$.

\footnotetext{
${ }^{108}$ A exposição se baseia em Ron Martin, The New Geography of Money, in Ron Martin (org.), Money and the Space Economy, Wiley, 1999, p. 3-28.

109 Esses centros financeiros globais se identificam inclusive pelo desenvolvimento de formas urbanas características, cuja estrutura arquitetônica se associa diretamente à simbologia da concentração financeira, como nos casos de Wall Street e da City londrina. A respeito ver David Porteous, The Development of
} 
Por sua vez, o aspecto geografia institucional do sistema diz respeito à própria organização do sistema e do modelo institucional adotado. Nesse sentido, sistemas que se organizam em âmbito nacional, como na Inglaterra e no Brasil, podem ter desempenhos distintos de sistemas cujo arranjo institucional se dá a nível regional, como no caso dos Estados Unidos, em que os bancos se organizam a nível estadual. Essa geografia institucional influencia a alocação de recursos no sistema, determinando sua distribuição entre localidades. Nesse sentido, por exemplo, sistemas pautados por bancos locais tenderiam a priorizar a economia regional em sua escala de prioridades enquanto filiais de bancos de âmbito nacional teriam menos incentivos a fazê-lo.

O terceiro aspecto é a regulação estatal da moeda e das instituições financeiras. A regulação pode assumir diversas formas, apresentar diferentes finalidades e contar com mecanismos e instituições diversificados. As várias combinações possíveis de elementos resultam em organizações geográficas distintas das instituições financeiras, determinando a geografia institucional do sistema e os padrões de fluxos de capitais pelo espaço.

O último aspecto considerado diz respeito ao financiamento público, que permite a redistribuição de recurso na economia, servindo de instrumento para alocação de recursos entre atividades, regiões, indivíduos, conforme suas finalidades.

Esses quatro aspectos influenciam a geografia do sistema financeiro e determinam o fluxo de recursos entre regiões. No entanto, vinham sendo negligenciados pela literatura convencional (ou ortodoxa) que examina o desenvolvimento regional.

O papel desempenhado pela moeda e mercados financeiros na economica regional era negligenciado porque as análises assumem, em geral, a premissa de neutralidade da moeda e de perfeita mobilidade dos fluxos financeiros inter-regionais. Nesse sentido, a análise ortodoxa do desenvolvimento regional desconsidera fatores relativos à moeda e ao sistema financeiro. Seu objeto é unicamente a denominada economia real, ou seja, a

Financial Centres: Location, Information, Externalities and Path Dependence, in Ron Martin (org.), Money and the Space Economy, op. cit., pp. 95-114. 
influência de fatores de produção e consumo de bens materiais ${ }^{110}$. No próximo item, apresenta-se um panorama dessa literatura e as principais críticas a ela dirigidas.

\subsection{Ortodoxia: a moeda como elemento neutro no processo de desenvolvimento}

A análise ortodoxa do desenvolvimento regional desconsidera fatores relativos à moeda e ao sistema financeiro, assumindo, em geral, a premissa de neutralidade da moeda e de perfeita mobilidade dos fluxos financeiros inter-regionais. Por isso, seria desnecessária a análise de fatores financeiros para se debater aspectos de desenvolvimento regional, cabendo unicamente analisar aspectos pertinentes à economia real.

A neutralidade da moeda implica na atribuição de um papel passivo a esse elemento, cuja oferta seria exogenamente determinada, ou seja, caberia à autoridade monetária criá-la e controlar sua oferta de acordo com as necessidades reais, restando aos bancos o papel passivo de distribuir o crédito entre regiões. Tendo em vista que a oferta de moeda se daria sob perfeita mobilidade de fluxos inter-regionais e que se assume que a autoridade monetária pode controlá-la, hipóteses de desequilíbrios desses fluxos nas regiões tenderiam a ser transitórias.

A literatura convencional assume ainda que a economia se rege por uma dinâmica de preços relativos; nesse sentido e, assumindo o livre fluxo de capitais, a taxa de juros tende a crescer em determinada região à medida em que haja uma menor oferta de crédito, atraindo assim os recursos necessários através do funcionamento livre desse mercado, estabelecendo-se um equilíbrio entre oferta e demanda. Ou seja, a oferta de crédito em regiões superavitárias, diante de aumento dos juros em outras regiões e da perfeita mobilidade do capital, tenderia a migrar para outras regiões para atender essa demanda (melhor alternativa de investimento), havendo, dessa maneira, perfeita elasticidade na oferta de crédito.

\footnotetext{
${ }^{110}$ A exposição neste ponto baseia-se amplamente em Sheila Dow e Carlos Javier Rodriguez-Fuentes, $U m$ "survey" da literatura de finanças regionais, in Marco Crocco e Frederico Jayme Jr (org.), Moeda e território: uma interpretação da dinâmica regional brasileira, Belo Horizonte: Autêntica, 2006, pp. 39-75.
} 
Diante desses aspectos, a teoria hortodoxa considera que a política monetária não teria impactos diretos sobre o desenvolvimento econômico das regiões. A taxa de juros de equilíbrio seria determinada pela disposição dos indivíduos em despeder suas rendas ou poupar, sendo todo o excedente necessariamente dirigido ao financiamento de outroas agentes. Nesse sentido, a moeda não assumiria qualquer conotação especulativa, restando seu papel limitado unicamente à função de intermediação das trocas.

Da mesma forma, os bancos também teriam um papel neutro, exceto na existência de falhas de mercado, que seriam capazes de obstar os fluxos financeiros inter-regionais ${ }^{111}$. Significa dizer que, desde que os mercados de crédito funcionem adequadamente, os fluxos financeiros inter-regionais serão responsáveis pelo equilíbrio, garantindo uma alocação eficiente de recursos e a neutralidade das variáveis monetárias. Portanto, nesse cenário, as instituições financeiras se organizariam e se localizariam pelo espaço de modo eficiente, e o movimento de capitais minimisaria a tendência ao desenvolvimento desigual das regiões.

Nessa concepção, a moeda poderia ter impactos regionais somente na hipótese de falhas de mercado, principalmente no que diz respeito a problemas de informação, que poderiam resultar em diferenciações regionais de taxas de juros e das elasticidades da oferta e da demanda de crédito. Essas hipóteses de falhas de mercado são analisadas principalmente pela literatura neo-keynesiana, cuja discussão parte de um modelo pautado por informações imperfeitas. Essa literatura procura analisar se informação imperfeita poderia limitar a mobilidade regional do capital, resultando em restrições regionais ao crédito. Segundo essa literatura, a assimetria de informações restringe a provisão de crédito pelas instituições nacionais em mercados regionais em razão da dificuldade em se obter informações sobre os melhores investimentos e do alto custo de monitoramente, fazendo com que o finacionamento das firmas locais dependa essencialmente de instituições financeiras locais, cuja proximidade e conhecimento da região incrementam seu nível informacional e reduzem os custos de monitoramento.

Nas últimas décadas, economistas considerados pós-keynesianos passaram a se preocupar de modo mais nítido com a relação entre espaço, sistema financeiro e

${ }^{111}$ Fernanda Faria Silva, Marco Aurélio Crocco e Carlos Javier Rodríguez-Fuentes, Limitações teóricas da literatura convencional sobre impactos regionais de política monetária, UFMG/CEDEPLAR, Belo Horizonte, 2010, pp. 14 e ss. 
desenvolvimento regional. Pautados em pressupostos keynesianos, esses autores consideram que o funcionamento dos mercados encerra em sua essência o que a teoria tradicional qualifica como falhas, e apontam que a moeda e sua alocação não são neutras no processo econômico, mas, ao contrário, influenciam as decisões dos agentes econômicos e têm consequências a nível regional. Assim, as escolhas e performances dos bancos estariam sujeitas a questões pertinentes à geografia organizacional e institucional do sistema financeiro, e poderiam levar a patamares de desenvolvimento desigual entre regiões, reforçando desigualdades regionais.

Nesse sentido, o livre jogo do mercado levaria, necessariamente, à perpetuação e extensão da desigualdade regional, sendo necessárias políticas públicas de intervenção sobre o sistema financeiro a fim de atenuar ou reverter essa tendência. Com o fim de analisar como o direito pode estruturar essas políticas, passamos, primeiramente, a analisar os principais pressupostos e conclusões alcançados por esses autores para se identificar com precisão o problema econômico a ser tratado pelo Direito.

\subsection{Sistema financeiro e desenvolvimento regional: a visão pós-keynesiana}

A teoria keynesiana constitui o ponto de partida do modelo elaborado por autores denominados pós-keynesianos para examinar diferentes padrões de desenvolvimento regional. Agregando elementos da Teoria da Dependência, eles apontam para o sistema financeiro como capaz de gerar processos cumulativos que acentuam a trajetória desigual de desenvolvimento em países com regiões com níveis severamente distintos de desenvolvimento. Segundo esse modelo, variáveis da economia real e do sistema financeiro intensificariam, no livre jogo do mercado, padrões de desenvolvimento desigual.

Nesse sentido, a moeda e sua alocação não seriam neutras no processo econômico, mas, ao contrário, influenciariam as decisões dos agentes econômicos e teriam consequências a nível regional. 
Existiriam alguns elementos nas escolhas e performance dos bancos - instituições capazes de influenciar a disponibilidade e alocação de recursos financeiros - que levariam a patamares de desenvolvimento desigual entre regiões, reforçando desigualdades regionais.

Essa linha de pesquisa evidencia que o livre jogo do mercado e a atuação racional dos agentes envolvidos levaria, necessariamente, à perpetuação e extensão da desigualdade regional, sendo necessárias políticas públicas de intervenção sobre o sistema financeiro a fim de atenuar ou reverter essa tendência.

A compreensão desse modelo exige, inicialmente, algumas considerações sobre a teoria desenvolvida por Keynes, especialmente sua teoria da preferência pela liquidez.

\subsubsection{A economia monetária de produção}

$\mathrm{Na}$ teoria econômica desenvolvida por Keynes, a moeda não é vista somente como um facilitador de trocas. A moeda não apenas permitiu a especialização do trabalho e a criação de arranjos produtivos antes inexistentes em comunidades baseadas somente no escambo de mercadorias, mas também muda a perspectiva pela qual os agentes observam a economia e ponderam suas escolhas. A moeda altera as possibilidades de acumulação de riquezas, que não se limita, na visão keynesiana, à acumulação de bens materiais. Acumular moeda é também uma alternativa de acumulação, capaz de afetar motivações e comportamentos dos agentes econômicos no curto e no longo prazo, não sendo apenas uma forma temporária de riqueza.

Essa concepção descontrói a teoria neoclássica que procurava determinar como as escolhas dos agentes econômicas são feitas e o processo de formação de preço dos bens num cenário de divisão do trabalho e troca de excedentes, em que os agentes econômicos são obrigados a fazer escolhas em razão da escassez dos bens (paradigma da "feira da aldeia"). Nessa economia de troca, a moeda é neutra pois constitui mero instrumento, um meio para satisfação de necessidades por meio da troca. 
A percepção de Keynes distingue-se à medida em que reconhece que muitas vezes os agentes econômicos preferem reter moedas a bens, mesmo que a moeda não satisfaça por si só nenhuma necessidade de consumo. Assim, a moeda não é apenas um meio de troca, mas é também uma reserva de valor já que transporta a riqueza no tempo. Por isso, não seria possível definir situações de equilíbrio, no curto ou no longo prazos, sem levar em conta as tendências da moeda e da política monetária.

Essa percepção, confirmada na prática e espelhada, inclusive, nos altos índices de desemprego resultantes da escolha dos agentes por reter moeda (o que não gera emprego) ao invés de consumir bens (que necessitam de trabalhadores para serem produzidos) à época de sua aparição, exigia completa alteração nos paradigmas de análise para que a base monetária dessa economia fosse reconhecida.

As razões para que os agentes econômicos prefiram reter moeda são pétreas para o desenvolvimento da teoria keynesiana e repousam na incerteza que cerca o futuro numa economia monetária de produção ${ }^{112}$.

Nesse ambiente em que as decisões não são reversíveis no tempo e, por isso, devem procurar antecipar expectativas sobre o futuro, o agente econômico é primeiramente um produtor e, somente posteriormente, consumidor. O desempenho de uma atividade produtiva (transformação de objetos da natureza em bens) é um elemento fundamental da constituição de um agente econômico que, no entanto, não satisfaz suas próprias necessidades por meio dessa atividade a não ser mediatamente, ou seja, produz para atender a demanda de terceiros e então ser dotado de recursos para satisfazer suas próprias necessidades. Esse cenário se intensifica à medida em que empresas - que não têm demandas de consumo - passam a ser as principais responsáveis pela produção (a empresa usa dinheiro para produzir dinheiro, e necessita equacionar custos e receitas).

\footnotetext{
112 A incerteza se diferencia do risco pois este é quantificável a partir de bases científicas, enquanto a incerteza não pode ser mensurada em bases probabilísticas. Keynes exemplifica com o jogo da roleta, que não é sujeito à incerteza, já que podem ser calculadas as chances de êxito com bases metodológicas confiáveis. Evento incerto é aquele em relação ao qual não podem ser calculadas probabilidades. Simplesmente não há base para isso. Para Keynes, o início de uma nova guerra mundial é incerto, já que simplesmente não se sabe se isso pode ou não ocorrer (nesse sentido, ver Adriana Amado, Disparate Regional Development in Brazil - A Monetary Production Approach, Aldershot: Ashgate, p. 40).
} 
No entanto, não há garantias de que a oferta de bens encontrará efetivamente demanda que a consuma. Essa incerteza sobre o destino da produção e sobre a capacidade do agente de atender suas próprias necessidades (ou, no caso das empresas, geras mais dinheiro) resulta no desenvolvimento de um sistema de contratos baseados em pagamentos em moeda para liquidação futura que mitigam a incerteza.

A existência de contratos viabiliza a economia moderna ao permitirem o compromisso acerca de comportamentos futuros, predeterminando receitas (definindo quantidade demandada e preço) bem como custos (estipulando as quantias a serem transferidas a fornecedores e à mão-de-obra empregada). Nesse contexto, a moeda não só deve servir como intermediária de trocas e padrão (medida) de valor, mas também deve ser capaz de assegurar a capacidade de satisfação de necessidades ao longo do tempo, exercendo assim a função de reserva de valor. Afinal, ninguém aceitaria direitos a liquidar por meio de um instrumento cujo valor fosse imprevisível à data de liquidação. Nesse sentido, uma moeda estável constitui elemento essencial no sistema contratual ${ }^{113}$.

Emerge assim um dos principais traços distintivos da teoria keynesiana: a moeda é vista como um elemento do processo produtivo, e não mero facilitador da troca de bens de consumo. O processo produtivo que caracteriza o capitalismo moderno, com altos investimentos, grandes economias de escala e que se efetiva no médio e no longo prazos, só são possíveis à medida em que os empresários possam ter alguma segurança sobre os custos de seus insumos se comparados ao preço que poderá cobrar do produto final, e também sobre a demanda esperada.

Nesse contexto, acumular riqueza sob a forma de bens de capital implica em risco superior à acumulação de ativos financeiros, uma vez que os ativos financeiros, principalmente a moeda, são dotados de maior liquidez. De um lado, a moeda é o ativo mais líquido, pois capaz de ser trocada por outros bens, e serve como parâmetro para aferir liquidez: quanto maior a facilidade em se vender um ativo, transformando-o em moeda, maior a liquidez a ele atribuída. De outro lado, a posse de bens de capital sujeita-o à incerteza quanto à demanda futura que esses bens são capazes de produzir, pois são específico para uso em determinada atividade ou à produção de outro tipo de bem. Por

${ }^{113}$ Fernando J. Cardim de Carvalho, A economia keynesiana e a moeda na economia moderna, in Macro Crocco e Frederico G. Jayme Jr., Moeda e território, op. cit., pp. 33 e ss. 
isso, dado um ambiente de incerteza, a acumulação de ativos financeiros é mais atraente que a de bens de capital $^{114}$.

Portanto, "pelo seu atributo de liquidez por excelência, a moeda acalma as inquietações dos agentes diante das incertezas do futuro, que são características de uma economia monetária." ${ }^{115}$ Como resultado, se a incerteza percebida pelos agentes é alta, mais alta é a tendência a reter moeda como meio de se resguardar quanto à imprevisibilidade do futuro; a retenção de moeda em detrimento de outros ativos em um momento de incerteza é, nesse sentido, um ato racional, pois permite aos agentes manter opções de escolha abertas face o futuro. Decorre dessa percepção que, quanto maior a incerteza, maior será a preferência pela liquidez e a disposição das pessoas em abdicar de alguma remuneração de seu capital em troca de maior liquidez (prêmio de liquidez).

\subsubsection{A teoria da preferência pela liquidez}

Essa concepção levou Keynes a elaborar o que restou conhecido como "teoria da preferência pela liquidez".

Essa teoria rejeita a tradicional concepção dos juros como o "preço" que equilibra a demanda por recursos - determinada pela produtividade marginal do investimento (demanda por poupança) - e a oferta de recursos, determinada pela propensão dos agentes de se abster do consumo imediato (propensão a poupar).

Para Keynes, a taxa de juros constitui uma recompensa por se abdicar da liquidez e, portanto, de reter riqueza na forma de moeda, que é o ativo mais líquido na economia:

"Deveria ser óbvio que a taxa de juros não pode ser um rendimento da poupança ou da espera como tal. Quando alguém acumula suas

\footnotetext{
${ }^{114}$ A demanda por moeda enquanto forma de riqueza passa a ser racional. No entanto, a demanda por moeda não perpetua o ciclo produtivo. A moeda viabiliza o sistema de contratos e a produção em massa mas, ao mesmo tempo, constitui em si um ativo atraente, capaz de concentrar em si a demanda por riqueza em detrimento dos bens reprodutíveis que geram bens de capital. Por isso, pode resultar em desemprego à medida que a demanda por moeda não requer empregos para sua produção.

${ }^{115}$ Fernando J. Cardim de Carvalho et. al, Economia Monetária e Financeira: teoria e política, p. 46.
} 
economias sob a forma de dinheiro líquido, não ganha juro, embora economize tanto quanto antes. Pelo contrário, a simples definição da taxa de juros diz-nos, literalmente, que ela é a recompensa da renúncia à liquidez por um período determinado, pois a taxa de juros não é, em sim outra coisa senão o inverso da relação existente entre uma soma de dinheiro e o que se pode obter desistindo, por um período determinado, do poder de comando da moeda em troca de uma dívida.

Desse modo, sendo a taxa de juros, a qualquer momento, a recompensa da renúncia à liquidez, é uma medida de relutância dos que possuem dinheiro alienar o seu direito de dispor do mesmo. A taxa de juros não é o preço que equilibra a demanda de recurso para investir e a propensão de abster-se do consumo imediato. É o preço mediante o qual o desejo de manter a riqueza em forma líquida se conciliar com a quantidade de moeda disponível." 116

A determinação da taxa de juros é vista assim como um evento eminentemente monetário, determinado tanto pela quantidade de moeda disponível quanto pela preferência pela liquidez dos agentes ${ }^{117}$. A preferência pela liquidez constitui assim um elemento determinante do que o público desejará reter dada determinada taxa de juros. Desse modo, a moeda constitui uma forma de conservação da riqueza e a taxa de juros é o preço que determina a escolha entre formas líquidas e ilíquidas de riqueza.

Nesse contexto, emerge a fundamental e antecedente questão proposta por Keynes: "dado que a taxa de juros nunca é negativa, por que alguém preferiria guardar sua riqueza de forma que renda pouco, ou nenhum juro, a conservá-la de outra que renda algum?"118

A existência de incerteza quanto ao futuro da taxa de juros é apontada por Keynes como uma condição necessária para a existência da preferência pela liquidez pela moeda como meio de conservação de riqueza.

\footnotetext{
116 John Maynard Keynes, Teoria geral do emprego, do juro e da moeda, 2.ed., São Paulo: Nova Cultural, 1985, p. 122.

117 "Isso implica que se a taxa de juros fosse menor, isto é, se a recompensa da renúncia à liquidez se reduzisse, o montante agregado de moeda que o público desejaria conservar excederia a oferta disponível e que, se a taxa de juros se elevasse, haveria um excedente de moeda que ninguém estaria disposto a reter. Se esta explicação for correta, a quantidade de moeda é outro fator que, aliado à preferência pela liquidez, determina a taxa corrente de juros em certas circunstâncias. A preferência pela liquidez é uma potencialidade ou tendência funcional que fixa a quantidade de moeda que o público reterá quando a taxa de juros for dada; resulta daí que ré a taxa de juros, M a quantidade de moeda e L a função da preferência pela liquidez, teremos $M=L(r)$. Isto mostra onde e como a quantidade de moeda entre no esquema econômico." (Ibidem, p. 122).

${ }^{118}$ Ibidem, p. 123.
} 
As expectativas quanto à taxa de juros resultante da psicologia de massas reflete sobre a preferência pela liquidez. Nesse sentido, Keynes defende que a taxa de juros tem um forte elemento expectacional e psicológico, pois os motivos que levam à liquidez também estão sujeitos a esses elementos. Mudanças na preferência pela liquidez, baseadas em diferentes informações e reformulação de expectativas causam também mudanças na taxa de juros. Assim, para cada conjunto de circunstâncias e expectativas, uma taxa de juros será identificada.

Keynes passa então a identificar os motivos que determinam a preferência pela liquidez, ou seja, por demandar moeda ao invés de manter a riqueza sob a forma de um ativo remunerado:

\footnotetext{
"As três divisões que acabamos de distinguir na preferência pela liquidez podem ser definidas pelos motivos que as governam: (i) o motivo transação, isto é, a necessidade de moeda para as operações correntes de trocas pessoais e comerciais; (ii) o motivo precaução, ou seja, o desejo de segurança com relação ao valor monetário futuro de certa parte dos recursos totais; e (iii) o motivo especulação, isto é, o propósito de obter lucros por saber melhor que o mercado o que trará o futuro." ${ }^{119}$
}

O motivo transação diz respeito ao intervalo entre o auferimento de renda e o dispêndio para pagamento de salários, aluguéis ou qualquer outra obrigação assumida para aquisição de bens ou serviços. Nesse sentido, o motivo transação implica na retenção de moeda para realização de uma compra específica em uma data determinada. $\mathrm{O}$ volume de moeda demandado nesse caso varia segundo o montante da renda e da duração normal do intervalo entre o seu recebimento e o seu desembolso, ou seja, dependerá das compras planejadas e dos hábitos de pagamento dos agentes.

O motivo transação para demandar moeda se aproxima da concepção ortodoxa sobre o papel da moeda, em que sua função está associada à intermediação de trocas. Os motivos precaução e especulativo, de outro lado, representam alterações significativas no modo de se analisar os fluxos monetários conforme a proposta de Keynes. Isso porque a demanda por moeda nesses casos não é explicada pela necessidade de aquisição de bens ou serviços. A retenção de moeda nesses caso apresenta-se como um escolha do agente diante da imprevisibilidade do futuro.

${ }^{119}$ Ibidem, p. 124. 
Como destacado acima, a retenção de moeda em detrimento de outros ativos em um momento de incerteza é vista por Keynes como um ato racional, pois permite aos agentes manter opções de escolha abertas face o futuro, que é incerto. Nesse sentido, quanto maior a incerteza, maior será a disposição das pessoas em abdicar de alguma remuneração de seu capital em troca de maior liquidez. Em outras palavras, pode-se dizer que será maior a preferência pela liquidez quanto maior a incerteza.

Em sua Teoria Geral, Keynes identificou dois motivos para retenção de moeda em face da incerteza: os motivos precaução e especulativo.

Uma vez que seu atributo de liquidez torna a moeda um ativo seguro que acalma as inquietações dos agentes diante das incertezas do futuro, os agentes podem reter moeda para atender contingências inesperadas ou oportunidades imprevistas para realização de negócios vantajosos. Nesse sentido, "a demanda precaucionária relaciona-se ao grau de ignorância sobre o futuro, com a moeda sendo o ativo que permite aos agentes refazerem rapidamente suas estratégias, caso desejem ou julguem necessário"120. É necessário destacar que a demanda precaucionária não se refere somente a preocupação com contingências. Keynes destaca também seu papel em permitir a realização de negócios vantajosos caso estes se apresentem ${ }^{121}$.

Por sua vez, o motivo especulação está relacionado à incerteza quanto ao comportamento futuro da taxa de juros.

Segundo Keynes, o motivo especulação requer um estudo mais detalhado por ser menos compreendido e por ser especialmente importante, uma vez que transmite os efeitos de uma variação na quantidade de moeda, sendo, nesse sentido, o canal por onde agirá a política monetária. Isso porque "a demanda de moeda para satisfazer o motivo especulação varia de modo contínuo sob o efeito de uma alteração gradual na taxa de juros $^{\prime \prime 22}$.

\footnotetext{
${ }^{120}$ Fernando J. Cardim de Carvalho et. al, Economia Monetária e Financeira: teoria e política, p. 50.

${ }^{121}$ John Maynard Keynes, Teoria geral do emprego, do juro e da moeda, op. cit., p. 140.

${ }^{122}$ Ibidem, p. 140.
} 
Deste modo, a incerteza quanto aos patamares futuros da taxa de juros constitui o elemento determinante da demanda especulativa por moeda, justificando assim a conservação de recurso líquidos. Note-se que a demanda por moeda aumenta à medida que a taxa de juros se reduz, até que a demanda se torne infinitamente elástica a determinado patamar baixo da taxa de juros. Quer dizer que dada uma taxa de juros a um patamar de tal modo baixo, que todos os agentes preferem manter consigo moeda (e sua liquidez) a ser remunerados por uma taxa de juros tão baixa (armadilha da liquidez).

Em momento posterior à publicação da Teoria Geral, no contexto dos debates entre Keynes e Bertil Ohlin, o motivo financeiro passou a ser referido como relevante para explicar a preferência pela liquidez. Esse motivo diz respeito à demanda por moeda antecipando alguma despesas planejada, sendo esse um gasto mais vultuoso e menos rotineiro, atrelado, em geral, ao investimento em bens de capital.

O motivo financeiro tem como pressuposto a necessidade de disponibilidade monetária antes do momento do investimento planejado, gerando uma demanda temporária e antecipada de moeda para essa despesa planejada. Trata-se da liquidez que os empresários necessitam deter entre o momento em que decidem investir (quando o gasto é só um plano), e o momento em que o dispêndio realmente ocorre.Como consequência, a demanda por moeda no motivo financeiro resulta, no agregado, da taxa de investimento.Assim, essa demanda adicional por moeda constitui uma limitador ao investimento, uma vez que afeta a economia como um todo incrementando a taxa de juros.

\subsubsection{A preferência pela liquidez como uma teoria de precificação de ativos}

Até este ponto, a análise Keynesiana considerava um mundo dicotômico, em que há apenas duas categorias de ativos, moeda e títulos. Nesse ambiente, há somente uma escolha em relação à possibilidade de retenção de moeda, o ativo mais líquido do sistema: a detenção de um título, ativo menos líquido remunerado por determinada taxa de juros. Nessa análise, a taxa de juros é, como destacado acima, o prêmio cobrado pelos agente para abdicar da liquidez proporcionada pelo moeda; constitui, nesse sentido, elemento 
determinante na escolha entre a forma líquida (a moeda) e a forma menos líquida de riqueza (o título).

Ainda em sua Teoria Geral, Keynes passa a desenvolver, no capítulo 17, uma teoria da precificação de ativos. Analisando sua obra, pode-se depreender que ele passa a generalizar sua teoria da preferência pela liquidez para compreender também uma teoria de

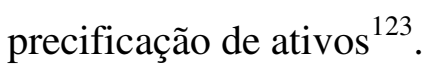

Nesse sentido, ele considera uma estrutura diversificada de ativos para, partindo do mesmo princípio geral da preferência pela liquidez, demonstrar que diferentes graus de liquidez exigem compensação pecuniária diversa para definição da taxa de retorno obtida com a detenção de determinado ativo, compensando-se assim sua relativa falta de liquidez se comparado a outro ativo de referência, em geral, a própria moeda, que é o ativo mais líquido na economia.

Assim, dada uma taxa de juros diversa para cada ativo, os agentes escolherão aqueles com a maior taxa de retorno possível. No entanto, deve-se notar que "a taxa de própria de juros de cada ativo é uma medida de seu retorno total esperado, medido não somente em termos do direito de renda implícito nele, mas também em termos da conveniência de sua posse e dos ganhos de capital que podem ser obtidos com sua venda". ${ }^{124}$

\footnotetext{
${ }^{123}$ É fato que parte da literatura que se desenvolveu a partir de Keynes assumiu que preferência pela liquidez significasse demanda unicamente por moeda, e que essa teoria se limitaria a predizer que a taxa de juros seria determinada pela oferta e demanda de moeda. No entanto, uma análise mais apurada da Teoria Geral revela que se trata de uma teoria de escolha de ativo. A crítica à uma concepção limitada da teoria é essencial: "Esta interpretação da preferência pela liquidez é, porém, discutível. Uma visão alternativa é de que se trata de uma teoria de escolha de ativos. De fato, como Keynes enfatizou em seu debate com Ohlin, em 1937, a preferência pela liquidez era uma teoria da escolha entre reter moeda ociosa e reter empréstimos, sendo o papel da taxa de juros equalizar a atratividade de cada um. Restringir a s escolhas de ativos a apenas duas possibilidades, moeda e bônus pagando juros, no entanto, não é essencial para a teoria, mas resulta da estrutura de agregação adotada na Teoria Geral. A taxa de juros era a recompensa por abrir mão de liquidez em um modelo onde havia apenas duas classes de ativos: ativos de curto termo, livres de risco de capital, chamados moeda, e ativos líquidos de longo termo, livres de risco de capital, chamados de bônus. Seria fácil estender, porém, o argumento para uma situação em que uma variedade maior de ativos existisse, ou pelo menos assim pensava Keynes. De fato, tal extensão foi realmente tentada no capítulo 17 da Teoria Geral, onde uma estrutura de agregação diferente, amis detalhada, foi adotada" (Fernando J. Cardim de Carvalho, Sobre a preferência pela liquidez dos bancos, in Luiz Fernando de Paul e José Luis Oreiro (org.), Sistema Financeiro - Uma análise do setor bancário brasileiro, Rio de Janeiro: Elsevier, 2007, p. 05.

${ }^{124}$ Fernando J. Cardim de Carvalho et. al, Economia Monetária e Financeira: teoria e política, op. cit., p. 55.
} 
Keynes identificou quatro atributos que os ativos possuem em graus diferentes e que determinam o retorno total esperado oferecido por cada ativo, ou seja, a sua taxa própria de juros.

Dentre esses atributos estão:

$q$ : a taxa de rendimento esperada a título de geração de rendas pela detenção do ativo a seu possuidor (lucro de uma atividade que emprega o ativo, juros, aluguéis, etc)

$c$ : custo de carregamento incorrido para a retenção do ativo, de modo a mantê-lo em seu estado original (guarda e estocagem do ativo, custo do seguro, etc.)

$a$ : apreciação ou depreciação dos valores de mercado do ativo no período entre a compra e o fim do período de retenção do ativo.

$l$ : prêmio de liquidez, ou seja, um retorno na forma de flexibilidade do ativo (facilidade de mudança da composição do portfólio caso necessário) que é relevante diante da incerteza no ambiente econômico.

O prêmio de liquidez compõe, nesse sentido, a retribuição que se espera de um bem, que equivale ao montante devido para se abdicar de sua disposição. No caso da moeda, o prêmio de liquidez é sempre mais elevado. Esse atributo é essencial na determinação da taxa própria de juros de cada ativo específico e também o mais original e capaz de distinguir a teoria Keynesiana:

"O poder de dispor de um bem durante certo tempo pode oferecer uma conveniência ou segurança potencial que não é igual para os bens de natureza diferente, embora sejam do mesmo valor inicial. Não há, por assim dizer, qualquer resultado em forma de produção no fim do período considerado e, mesmo assim, trata-se de algo pelo qual as pessoas estão dispostas a pagar um preço. Chamaremos prêmio de liquidez de certo bem ao montante (medido em termos de si mesmo) que as pessoas estão dispostas a pagar pela conveniência ou segurança potenciais proporcionadas pelo poder de dispor dele (excluindo o rendimento ou os custos de manutenção que lhe são próprios)."125

${ }^{125}$ John Maynard Keynes, Teoria geral do emprego, do juro e da moeda, op. cit., p. 159. 
Considerando os quatro atributos apresentados e assumindo a hipótese de cada classe de ativos possui uma taxa singular de juros (r), o retorno esperado de um ativo é definido a partir da soma das diferentes taxas esperadas:

$$
\mathrm{r}=a+q-c+l
$$

Nesse sentido, o retorno esperado do ativo é identificado por $(a+q-c)$, que é contrabalançado pelo prêmio de liquidez $(l)$. Em outras palavras, diferentes combinações de retornos esperados e prêmios de liquidez oferecidos por ativos diversos determinam alterações na estrutura de demanda pelos ativos. Os agentes compararão e escolherão, a partir de suas preferência individuais e conhecimento do ambiente econômico, entre ativos que oferecem diferentes níveis de rendimento $(q-c)$, ganhos de capital $(a)$ e segurança e flexibilidade conferidas por maior liquidez $(l)$.

Nesse contexto, uma alta na incerteza percebida pelos agentes incrementa o valor de se ter maior liquidez, de modo que a preferência pela liquidez causaria deslocamentos nas curvas de demanda fazendo com que ativos com altas taxas de retorno mas pouca liquidez sejam preteridos em relação a ativos com maior liquidez e menor taxa de retorno. Por isso, quando a incerteza é mais alta, um alto grau de liquidez se torna mais valioso, de modo que aqueles que valorizam a liquidez podem estar dispostos a pagar altos prêmios abdicando de retorno de capital $(\mathrm{a}+\mathrm{q}-\mathrm{c})$ - para permanecerem líquidos.

Nesse sentido, pode-se concluir que a teoria da preferência da liquidez constitui sim uma teoria de precificação de ativos:

\footnotetext{
"Com liquidez sendo entendida nesse contexto mais amplo, a afirmação fundamental da teoria da preferência pela liquidez permanece a mesma: a taxa de retorno esperada de um ativo tem de ser tal que compense seu grau de iliquidez, dado o grau de incerteza sentida pelos detentores de ativos que determina se prêmio de liquidez, isto é, o volume de retornos monetários que os agentes estão preparados para abrir mão em troca daquela liquidez. Em consequência, em equilíbrio, como os agentes avaliam a iliquidez de um dado ativo se reflete na sua taxa esperada de retorno e, assim, em seu valor corrente de mercado." ${ }^{126}$
}

\footnotetext{
${ }^{126}$ Fernando J. Cardim de Carvalho, Sobre a preferência pela liquidez dos bancos, op. cit., p. 09.
} 
Essa percepção é relevante pois é adotada pelos teóricos pós-keynesianos em suas proposições. É o que se passa a discutir.

\subsection{Preferência pela liquidez e as diferentes instituições e ambientes regionais}

Destaque-se, nesse contexto, que diferentes instituições e organizações resultam em liquidez distintas dos ativos existentes na economia. Assim, arranjos institucionais e organizacionais diferentes segundo a região em que se localizam têm como consequência diferenças na liquidez dos ativos existentes em cada região. Assim, regiões que tenham instituições e organizações menos desenvolvidas têm ativos menos líquidos, o que torna os ativos financeiros mais atrativos. Como resultado, a disponibilidade de moeda é preferível em razão de sua liquidez superior.

Essas diferenças entre as regiões passam também por níveis distintos de incerteza. Regiões sujeitas a maiores incertezas apresentam maior preferência pela liquidez, conservando ativos financeiros e tornando menos líquidos outras formas de ativos. Como consequência, regiões sujeitas a níveis diferentes de incerteza e com arranjos institucionais e organizacionais diversos têm preferências pela liquidez distintas, sendo que quanto maior a incerteza e mais fracos os arranjos, maior a preferência por ativos financeiros.

A preferência pela liquidez aumenta nessas regiões em razão dos motivos precaucional e especulativo.

\subsubsection{O papel do sistema financeiro na trajetória desigual de desenvolvimento regional}

A teoria keynesiana constitui o ponto de partida do modelo elaborado por S. Dow para examinar diferentes padrões de desenvolvimento regional. Agregando elementos da Teoria da Dependência, ela aponta para o sistema financeiro como capaz de gerar processos cumulativos que acentuam a trajetória desigual de desenvolvimento em países com regiões com níveis severamente distintos de desenvolvimento. A teoria desenvolvida 
por Dow não nega a importância do setor real na determinação das relações econômicas ${ }^{127}$. O que ela pretende é demonstrar que as análises regionais não podem desconsiderar o elemento financeiro. Segundo esse modelo, variáveis da economia real e do sistema financeiro intensificariam, no livre jogo do mercado, padrões de desenvolvimento desigual $^{128}$.

O modelo de Dow baseia-se em uma dicotomia entre dois polos regionais diversos: o centro e a periferia. A região central é caracterizada por um padrão mais estável e autosustentável de crescimento, maior desenvolvimento do sistema financeiro e dos arranjos institucionais e uma propensão menor às importações. Por sua vez, a periferia caracterizase pelos opostos: um padrão de desenvolvimento instável e baseado em exportações, sistema financeiro e instituições menos desenvolvidas e baixos níveis de renda junto à concentração da produção no setor primário ${ }^{129}$.

Nesse contexto, o sistema financeiro contribui para o desenvolvimento desigual entre as regiões ao limitar o crédito disponível na região periférica em comparação à região central e ao incrementar o custo do crédito naquela região em relação ao centro. Segundo a teoria pós-keynesiana, esse resultado advém naturalmente do livre jogo do mercado e tem sua explicação essencialmente nas diferentes preferências pela liquidez dos demandantes e ofertantes de crédito nessas regiões ${ }^{130}$. A tabela abaixo sintetiza as diferenças entre centro e periferia $^{131}$ :

127 "The forces behind this process of uneven development are many and complex, both real and financial; of
the financial forces, money and the banks which create it are only a part. The focus here on money and
regional development, therefore, should not be taken as a denial of the significance of more general forcer
between regional economies, or of the complexity of financial markets, or of the international dimension."
(Sheila Dow, Money and Regional Development, in Sheila Dow, Money and the Economic Process,
Aldershot: Edward Elgar, 1993, p. 121).
128 "In conclusion, Money and financial variables in general play an important part in the emergence and
persistence of regional disparities. So any theory without them is missing an importante element" (Sheila
Dow, Incorporating Money in Regional Economic Models, in Sheila Dow, Money and the Economic
Process, op. cit., 1993, p. 121).
129 "While most regions occupy some middle ground, it is possible to identify regions which can be treated as
polar cases: Central regions and Peripheral regions. The analysis here will concentrate on these polar cases
in order to highlight the financial implications of their real economic differences. Thus, centre, an archetypal
central region, is characterized by prosperity which is expected to continue, active markets and financial
sophistication. Periphery, an archetypal peripheral region, has a stagnating economy, thin markets and a
lesser degree of financial sophistication." (Sheila Dow, The Regional Composition of the Bank Multiplier
Process, in Sheila Dow, Money and the Economic Process, op. cit., p. 77).
130 A preferência pela liquidez varia regionalmente: "Keynes theory of liquidity preference suggests that the
preference for holding liquidity Will be greatest where confidence in expected yields of alternative assets is
lowest. Given that spatial differences in economic conditions are common, we can expect a spatial character 


\section{TABELA III - DIFERENÇAS ENTRE CENTRO E PERIFERIA NA TEORIA PÓS- KEYNESIANA}

\begin{tabular}{|c|c|c|c|}
\hline Característica & Centro & Periferia & Preferência pela Liquidez \\
\hline $\begin{array}{c}\text { Trajetória de } \\
\text { crescimento }\end{array}$ & Estável & Instável & Periferia $>$ Centro \\
\hline $\begin{array}{c}\text { Variável } \\
\text { dinâmica }\end{array}$ & $\begin{array}{c}\text { Endógena } \\
\text { (investimento) }\end{array}$ & $\begin{array}{c}\text { Exógena } \\
\text { (exportação) }\end{array}$ & Periferia > Centro \\
\hline $\begin{array}{c}\text { Concentração da } \\
\text { produção }\end{array}$ & $\begin{array}{c}\text { Secundária e } \\
\text { terciário }\end{array}$ & $\begin{array}{c}\text { Primário e } \\
\text { terciário }\end{array}$ & Periferia $>$ Centro \\
\hline $\begin{array}{c}\text { Propensão a } \\
\text { importar }\end{array}$ & Baixa & Alta & Periferia $>$ Centro \\
\hline $\begin{array}{c}\text { Arranjos } \\
\text { institucionais }\end{array}$ & Sólidos & Fracos & Periferia $>$ Centro \\
\hline $\begin{array}{c}\text { Mercado } \\
\text { financeiro }\end{array}$ & Desenvolvidos & $\begin{array}{c}\text { Pouco } \\
\text { desenvolvidos }\end{array}$ & Periferia $>$ Centro \\
\hline $\begin{array}{c}\text { Liquidez dos } \\
\text { ativos }\end{array}$ & Alta & Baixa & Periferia $>$ Centro \\
\hline $\begin{array}{c}\text { Base para difusão } \\
\text { de informação } \\
\text { Incerteza }\end{array}$ & Sólida & Volátil & Periferia $>$ Centro \\
\cline { 2 - 5 } & Reduzida & Elevada & Periferia > Centro \\
\hline \multicolumn{2}{|c|}{}
\end{tabular}

Como discutido acima, por meio do sistema bancário, os mais diversos agentes econômicos interagem indiretamente, através da transferência de recursos de agentes econômicos que depositam seu capital nas instituições bancárias e seu repasse para outros, que procuram capital. Conhecida como intermediação financeira, essa atividade permite que os bancos recolham os recursos dispersos pela população e os direcionem àqueles que necessitam de empréstimos ${ }^{132}$, conservando apenas uma parcela dos depósitos para atender aos saques dos depositantes gerando assim maior quantidade de capital disponível na economia para investimento.

to liquidity preference" (Sheila Dow, The Stages of Banking Development and the Spatial Evolution of Financial Systems, in Ron Martin (org.), Money and the Space Economy, op. cit., p. 34).

131 Melissa Menezes, Marco Crocco, Elisângela Sanches e Adriana Amado, Sistema financeiro $e$ desenvolvimento regional: notas exploratórias, in Luis Fernando de Paul e José Luís Oreiro, Sistema financeiro - uma análise do setor bancário, op. cit., 2007, p. 290.

${ }_{132}$ Os bancos realizam o negócio jurídico de crédito, ou seja, tornam-se devedores daqueles que neles realizam depósitos com o único objetivo de se tornar credores, utilizando-se desse capital. 
A atividade dos bancos é caracterizada pelo denominado efeito multiplicador: uma vez que o capital empestado é novamente depositado, ele pode ser na seqüência empestado a outro agente econômico e assim por diante (cria-se assim a denominada moeda escritural ou bancária). Portanto, o passivo dos bancos torna-se moeda a ser usada e poder ser muitas vezes multiplicada.

A capacidade dos bancos em incrementar seu potencial de multiplicação da moeda depende do desenvolvimento tanto das instituições que o cercam quanto do seu próprio desenvolvimento organizacional. É nesse sentido que podem ser identificados diferentes estágios do desenvolvimento bancário, que impactam diretamente a capacidade do banco de criação de moeda. Pode ser identificada uma trajetória de desenvolvimento do sistema bancário, que parte de estágios primários em que a intermediação financeira evolui para a utilização dos depósitos como moeda e geração do efeito multiplicador, para estágios em que essa atividade se aperfeiçoa com a criação de mecanismos de segurança, que permitem atuações mais agressivas na criação de moeda ao aumentar a confiança no sistema, como o estabelecimento de mecanismos para empréstimos interbancários e a criação de um banco central como emprestador de última instância.

Além disso, o desenvolvimento de outros mecanismos financeiros (como o mercado de capitais) exige que o sistema bancário se desenvolva e passe a competir por recursos: mecanismos de captação mais sofisticados são criados, o que gera também mecanismos de investimentos diferenciados (como, por exemplo, as atividades com derivativos) ${ }^{133}$.

Em geral, observa-se que as regiões periféricas contam com bancos em estágios menos avançados de desenvolvimento. Nessas regiões, os mecanismos de captação são menos sofisticados, o que torna os bancos mais dependentes dos redepósitos para geração de crédito. Essa percepção ganha importância à medida que se percebe que a dinâmica de fluxo de capitais entre-regiões elimina a ideia de um "revolving fund" dos recursos monetários, conforme desenvolvida por Keynes ${ }^{134}$.

\footnotetext{
133 Os diferentes estágios do desenvolvimento bancário são analisados por Sheila Dow, The Stages of Banking Development and the Spatial Evolution of Financial Systems, op. cit., pp. 36-40.

${ }^{134}$ A respeito ver Adriana Amado, Disparate Regional Development in Brazil - A Monetary Production Approach, op. cit, p.70, e Pietro Alessandrini e Alberto Zazzaro, A 'Possibilist' Approach to Local Financial
} 
Ao se considerar a existência de diferentes preferências pela liquidez a nível regional, é possível identificar uma tendência a que os bancos localizados na periferia tenham maior dificuldade em gerar crédito. As regiões periféricas são tipicamente instáveis, o que incrementa o grau de incerteza de seus agentes, tanto no lado da demanda quanto da oferta de crédito. Como resultado, os agentes na periferia (tanto do lado da demanda de crédito quanto da oferta) têm maior preferência pela liquidez em comparação aos agentes localizados no centro. Essa assimetria nas preferências pela liquidez em cada uma das regiões reflete sobre a capacidade dos bancos da região periférica gerarem crédito:

\footnotetext{
“(...) The liquidity of any given asset is thus less in Periphery than in Centre. In the long-run, then, Centre's bank multiplier is higher than Periphery's, a tendency accentuated in the short-run by bullish expectations in the former regions and bearish expectations in the latter. Other things being equal, then, the money supply is higher where liquidity preference is lower.",135
}

No lado da demanda, a maior preferência pela liquidez dos agentes na periferia deve-se aos motivos precaucional e especulativo: dada a instabilidade da região, os agentes preferem manter moeda consigo ou, ao menos, aplicações com menor rendimento e maior liquidez, de modo a poder enfrentar despesas inesperadas (que são mais comuns na periferia) ou aproveitar oportunidades de investimento que venham a aparecer (a atividade especulativa é intensa na periferia). Esse contexto reduz a disponibilidade de depósitos e a capacidade dos bancos de gerar crédito (menor multiplicador monetário), o que se intensifica à medida que:

(i) Os agentes têm um nível de renda inferior e tendem a manter maior proporção de dinheiro em espécie para suas despesas cotidianas, reduzindo o volume de depósitos (maior relação dinheiro/depósito).

(ii) $\mathrm{O}$ menor nível de renda reflete-se ainda sobre o acesso a instrumentos financeiros. Esses agentes muitas vezes mantêm-se em situação de extrema informalidade sem, nem mesmo, contar com uma conta bancária.

Systems and Regional Development: the Italian Experience, in Ron Martin (org.), Money and the space economy, p.71.

${ }^{135}$ Sheila Dow, The Regional Composition of the Bank Multiplier Process, op. cit., p. 77. 
Como consequência da maior preferência pela liquidez na região periférica, os agentes demandam mais moeda, o que termina desvalorizando os demais ativos nessa região. De outro lado, a maior estabilidade e desenvolvimento institucional da região central tornam seus ativos financeiros e não financeiros mais atrativos. Dessa forma, os mercados dos diferentes ativos no centro têm maior volume de transações, o que garante a eles maior liquidez. Como resultado, os agentes localizados na periferia tendem a satisfazer sua preferência pela liquidez com ativos localizados na região central, o que termina drenando recursos da periferia em direção ao centro e reduzindo a taxa de redepósito nos bancos da periferia.

Essa drenagem de recursos significa a redução dos multiplicadores monetários na periferia e a redução da capacidade dos bancos nessa região de gerar crédito:

\begin{abstract}
"This reduces the redeposit ratio in the financial institutions of the peripheral region, reducing their ability to extend credit, just as the increase in their own liquidity preference reduces their willingness to commit their assets to advances to local industry. (...) But the interdependence suggested above refers to shifts both in the demand schedules and in the supply schedules, whatever they are, in response to changes in liquidity preference (or confidence in expectations as to the value of relevant assets). The specific interdependence arises from the fact that asset choices of the non-bank public directly affect the capacity of banks to extend credit, at the same time as banks themselves will be subject to similar influences in their asset choice."136
\end{abstract}

Esse processo de transferência de recursos de uma região para a outra é ainda intensificado por elementos de economia real. Como a região central costuma ser mais industrializada, a região periférica acaba exportando produtos primários para a região central e importando especialmente produtos industrializados e de maior valor agregado, transferindo, por isso, uma quantidade considerável de recursos para o centro e perpetuando a relação de dependência entre as duas regiões ${ }^{137}$.

\footnotetext{
136 Sheila Dow, Incorporating Money in Regional Economic Models, op. cit., pp. 117 e ss. Nesse sentido, er também Sheila Dow, The Treatment of Money in Regional Economics, in Sheila Dow, Money and the Economic Process, op. cit., p. 104.

137 "The economic structure of each region is quite different, with activity in periphery geared towards exporting to Centre. Peripheral activity is usually in primary products, or manufacturing at low level of processing. (...) There are positive, spread effects from Centre in the form of export demand, and the extension of technology, expertise and services to Periphery through branch plant operations. But the form of these spread effects is such as to promote Periphery`s dependence on Centre" (Sheila Dow, Money and Regional Development, op. cit, p. 147).
} 
A perspectiva dos ofertantes de crédito também é muito relevante. Nesse sentido, a oferta de crédito na região periférica é limitada pela maior preferência pela liquidez dos bancos. O ambiente de instabilidade e incerteza na periferia faz com que os bancos tendam a aumentar a quantidade de reservas em relação ao volume de depósitos (maior relação reserva/depósitos):

\begin{abstract}
"Therefore, the regional financial constraint has origins in the two sides of the balance sheets of the banks. On the one hand, there are problems related to the redeposit ratio in the periphery. This makes banks constrain their levels of extended credit, since there is a continuous leakage of reserves from the peripheral banking system to the central banking system. On the other hand, there is the problem with the more uncertain environment of the periphery that makes banks more cautious about extending credit to those regions." 138
\end{abstract}

Essa perspectiva da atuação dos bancos pressupõe um sistema bancário segmentado por regiões. No caso de um sistema bancário sem limites à atuação regional, o arcabouço teórico analisado é também aplicável. Mais do que isso, num sistema bancário com bancos atuando nacionalmente, há uma tendência ainda mais acentuada para o desenvolvimento financeiro desigual entre as regiões e a escassez de crédito na periferia, posto que o fluxo de capitais da periferia para o centro se torna ainda mais fácil.

Num sistema nacional, os bancos com atuação regional tendem a concentrar o crédito em projetos com foco na região, procurando assim desenvolver sua região de atuação e manter os redepósitos dentro de sua área de captação. Desse modo, bancos que atuam somente regionalmente procuram evitar o financiamento de projetos ligados a outras regiões, procurando reduzir assim a drenagem de recurso da periferia para o centro.

Por sua vez, os bancos que atuam nacionalmente não enfrentam problema na constituição de sua base de depósitos: não importa para onde o dinheiro se dirija, a abrangência desses bancos permite que eles sejam capazes de se fazer presentes e captar esses recursos. No entanto, ainda que a drenagem de recursos da periferia pelo centro não impacte a atividade desses bancos, a drenagem ainda é um problema para a região como um todo. Em outras palavras, os bancos de atuação nacional não tendem a conter a drenagem de recursos ou atenuá-la. Ao contrário, a atuação desses bancos tende a acentuar

\footnotetext{
${ }^{138}$ Adriana Amado, Disparate Regional Development in Brazil - A Monetary Production Approach, op. cit.,
} p. 44. 
esse processo ao incentivar projetos ligados à região de seu centro decisório - o centro -, o que termina por estimular a drenagem de recursos da periferia para o centro. Dessa forma, a retenção de recursos pela periferia vai se tornando cada vez mais difícil e o déficit da periferia vai gradualmente aumentando.

Como resultado, ainda que os bancos com atuação nacional não sejam limitados pelas reservas geradas em nível local, esse déficit estrutural limita a extensão de empréstimos para essas regiões. Além disso, como os núcleos decisórios desses bancos localizam-se na região central, eles detêm maior nível de informações sobre os mercados do centro e sobre as empresas alí localizadas. Assim, a preferência pela liquidez dos bancos faz com que o crédito se dirija ao centro em razão da maior confiança nos ativos e nas empresas localizadas nessa região. E mais, projetos financiados na periferia envolverão, em geral, filiais ou subsidiárias de empresas do centro ${ }^{139}$.

Segundo S. Dow, essa discrepância entre o centro e periferia faz com que haja uma taxa de juros praticada a nível nacional e outra específica para determinadas localidades. Em razão da maior preferência pela liquidez das instituições bancárias na periferia, elas apenas estariam dispostas a reduzir sua liquidez transferindo recursos a outros agentes na forma de empréstimos em troca de uma remuneração superior (maior taxa de juros). Mesmo nessa hipótese, o nível de incerteza nas regiões periféricas é tão considerável que o incremento na taxa de juros não seria capaz de compensar integralmente o maior risco percebido na realização de empréstimos na periferia ${ }^{140}$. A baixa taxa de redepósitos na periferia e a drenagem de recursos pelo centro influenciam a percepção dos bancos sobre o retorno dos investimentos e indicam uma tendência à estagnação na região. Dessa forma, a despeito do incremento da taxa de juros, a limitação do crédito ainda é contundente na periferia $^{141}$.

A maior restrição da base de depósitos dos bancos que atuam em nível regional e a maior sofisticação dos bancos sediados no centro, que têm maior acesso a formas de captação de recursos diversas, levam a uma esperada desvantagem competitiva entre os

\footnotetext{
${ }^{139}$ Relevante a análise de Pietro Alessandrini e Alberto Zazzaro, A 'Possibilist' Approach to Local Financial Systems and Regional Development: the Italian Experience, p. 84.

${ }_{140}$ Adriana Amado, Disparate Regional Development in Brazil, op. cit., p. 43.

${ }^{141}$ Sheila Dow, Money and Regional Development, op. cit, p. 150.
} 
bancos regionais e os nacionais. Esse contexto dá lugar a uma tendente concentração do mercado sistema bancário, com a prevalência dos bancos nacionais.

Essa tendência à concentração bancária, somada à tendência dos bancos da região central de financiar projetos no centro ou envolvendo filiais de empresas sediadas no centro, dão lugar a uma tendência de concentração industrial. Esse processo resulta do déficit informacional que os núcleos decisórios de bancos nacionais apresentam com relação à periferia, que os leva a concentrar empréstimos em empresas de dimensão nacional em detrimento de empresas regionais ${ }^{142}$. Além dessa concentração do crédito no centro ou em projetos originados por empresas sediadas no centro, é intensificado pela desvantagem competitiva das empresas locais: o crédito para elas custa mais caro, e é difícil repassar esse custo maior ao consumidor dada a grande concorrência vinda da região central.

Dessa forma, o livre jogo do mercado tende a acentuar a concentração do crédito na região central, que será acompanhado pela concentração das instituições financeiras, restando especialmente aquelas sediadas no centro e com atuação nacional. Esse processo dará lugar a uma tendência de concentração industrial e ao desenvolvimento regional desigual, acentuando o processo de dependência entre centro e periferia:

"Therefore, the evolution of the banking system tends to intensify the
tendencies that were latent at stage 2 of banking development, that is, an
inherent tendency towards a disparate development of credit creation that
generates an unequal pattern of real development of central and
peripheral economies. This tendency is intensified by another element
that contributes to the smaller peripheral money multiplier, which is the
higher liquidity preference of peripheral banks that tends to result in a
higher reserve/deposit ratio. This is a consequence of the strong
instability and consequent uncertainty that characterizes these economies.
This tendency intensifies the process of banking concentration, since
banks that operate at a nationwide level present competitive advantages
over local banks in their capacity to extend loans and increase deposits.
These facts are self-reinforcing and are mainly generated by the logic of

142 "When the tendency towards banking concentration is combined with information problems that concentrating decision-making at the centre's head offices brings with it, a new tendency appears, that is the tendency towards industrial concentration. This process is a result of the remoteness of the peripheral regions and of the subsequent strong conventional character that the loan decisions assume. These elements favour the extension of credit to nationwide corporations operating in peripheral regions with head offices at the centre than to local enterprises, because the information base of the projects of those corporations is less uncertain to head offices of the banks of the centre." (Adriana Amado, Disparate Regional Development in Brazil, op. cit., p. 44). 
the free-play of market forces which tends to intensify the uneven pattern of development generated by real and financial causes.

(...) Consequently, if financial forces are let free, there would be a strong tendency towards financial concentration at the centre. This would bring an inherent tendency to industrial concentration, in which nationwide enterprises would have comparative advantages in relation to peripheral enterprises, since the decision to extend loans is strongly based on conventional procedures and will tend further to constrain the possibilities of growth at the periphery."

\subsection{A experiência brasileira: desenvolvimento desigual entre regiões e a concentração do sistema financeiro}

O financiamento das atividades produtivas é um aspecto muito relevante no desenvolvimento, geralmente atribuído ao sistema bancário e ao mercado de capitais. No caso brasileiro, a despeito do crescimento do mercado de capitais nos últimos anos, ele ainda é restrito a grandes empresas, sendo o financiamento bancário essencial para os setores produtivos. No entanto, observa-se que o setor bancário no Brasil "foi muito competente para sobreviver à instabilidade, mas não se mostrou capaz de gerar o volume de crédito e o funding do investimento em condições razoáveis para estimular o crescimento econômico sustentável. ${ }^{\prime 144}$

Um primeiro indicador relevante é o volume de crédito disponibilizado pelo sistema bancário. E o volume de crédito em relação ao tamanho do PIB brasileiro evidencia que o volume de crédito financeiro no Brasil é muito reduzido, especialmente quando comparado a outros países. Nesse sentido, o mercado de crédito no Brasil corresponde a aproximadamente $45 \%$ do $\mathrm{PIB}^{145}$, enquanto que em países como a China ele chega a $178,8 \%$ do PIB $^{146}$.

\footnotetext{
${ }^{143}$ Adriana Amado, Disparate Regional Development in Brazil, op. cit., p. 47.

${ }^{144}$ Antonio José Alves Jr, Sistematização do debate sobre "Sistemas de Financiamento do Desenvolvimento", in Desenvolvimento em debate: novos rumos do desenvolvimento no mundo, Rio de Janeiro: BNDES, 2002, p. 332

${ }_{145}$ Segundo Relatório de Economia Bancária e Crédito do BCB, 2010 (www.bcb.gov.br).

${ }^{146}$ World Bank, Brazil Investment Climate Assesment N. 2 (2005).
} 
Segundo, o crédito disponível não se destina a investimentos produtivos, que requerem financiamentos de longo prazo. Ao contrário, o crédito financeiro no Brasil, além de exíguo, limita-se a financiar o consumo (especialmente por meio de financiamentos diretos aos consumidores por instrumentos de alta lucratividade como cartão de crédito, financiamentos de veículos e outras modalidades de crédito direto ao consumidor no curto prazo) e o capital de giro das empresas, ou seja, o capital necessário ao custeio das atividades e não ao investimento em novas atividades. Dados do BCB demonstram que o crédito de longo prazo - superior a 5 anos - tem crescido no Brasil, mas ainda representa uma parcela pequena do total:

\section{GRÁFICO I}

\section{Composição do Crédito Bancário no Brasil (em \%)}

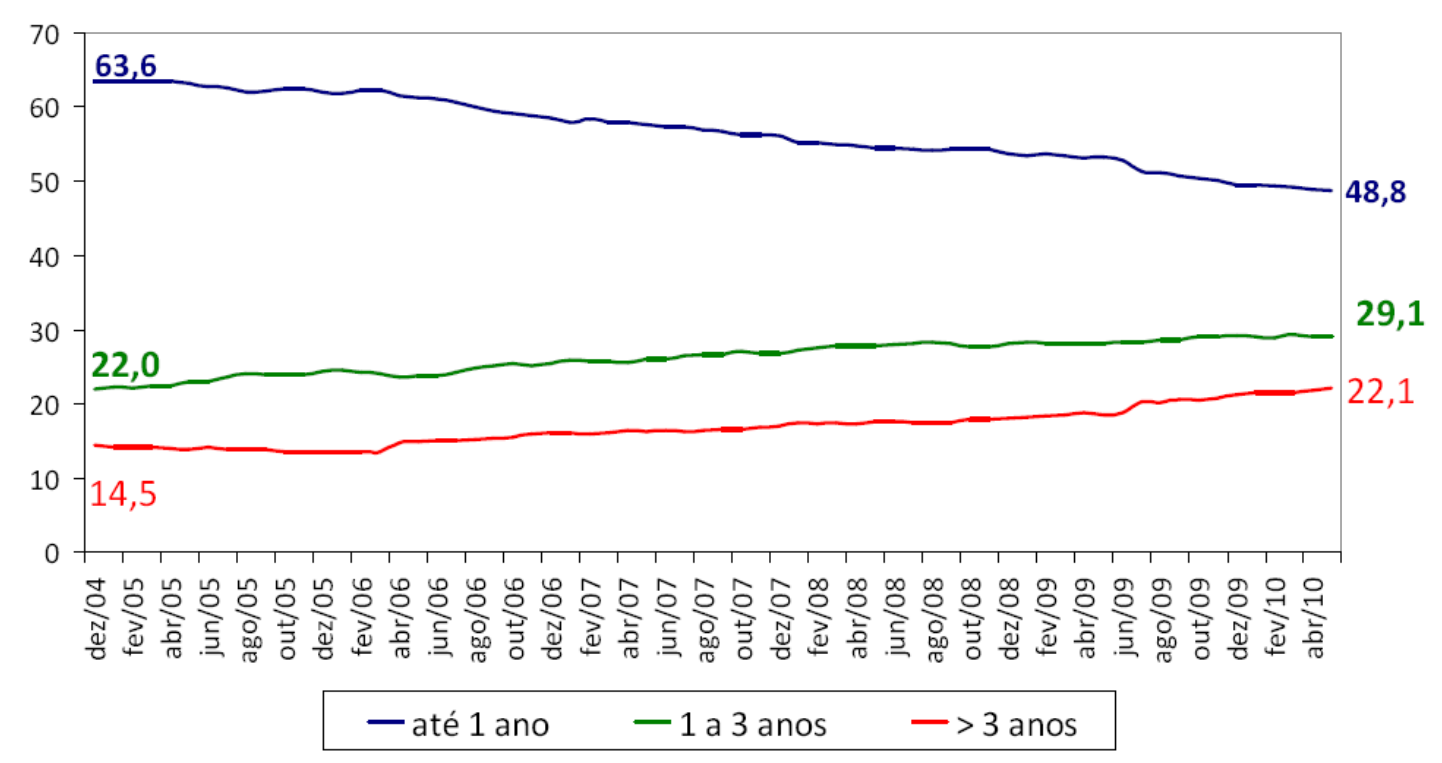

Fonte: BNDES ${ }^{147}$

Além disso, o setor bancário privado permanece muito distante do financiamento produtivo. Essa modalidade de financiamento, fundamental para o desenvolvimento econômico, permanece muito dependente da atuação dos bancos públicos, que permanecem com um papel fundamental no contexto brasileiro. Nesse contexto, o crescimento das instituições bancárias privadas no Brasil (tanto instituições de capital eminentemente nacional quanto aquelas de origem estrangeira, que cresceram no Brasil essencialmente por meio de aquisições) passa ao largo do financiamento produtivo. A

\footnotetext{
${ }^{147}$ Os gráficos I, II e III a seguir encontram-se disponíveis em www.bndes.gov.br.
} 
despeito de existir no Brasil um sistema bancário robusto e que apresenta elevado nível de desenvolvimento tecnológico, o desenvolvimento econômico em sua faceta de crescimento e inovação produtivas é majoritariamente financiado por recursos próprios das empresas ou por bancos públicos.

Nesse sentido, dados do Banco Nacional de Desenvolvimento Econômico e Social (BNDES) e do Ministério a Fazenda demonstram que esse banco é o principal responsável pelo financiamento das atividades produtivas no país (exceto pelo auto-financiamento), e que os bancos privados têm pequena participação nos investimentos de prazo superiores a 5 anos:

\section{GRÁFICO II}

\section{Padrão de Financiamento dos Investimentos na Indústria e na Infraestrutura (2004-2009)}

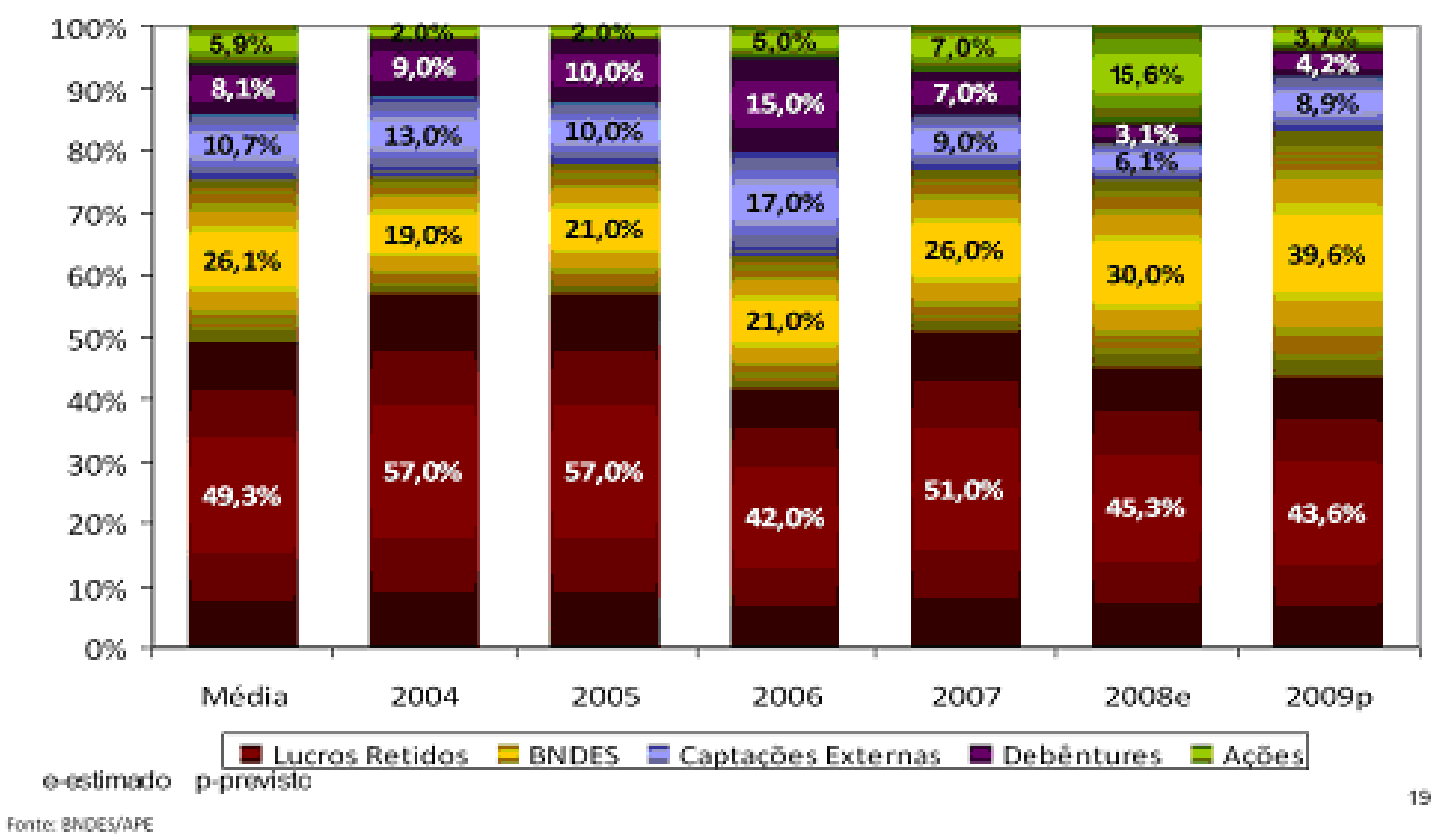

Fonte: BNDES 


\section{GRÁFICO III}
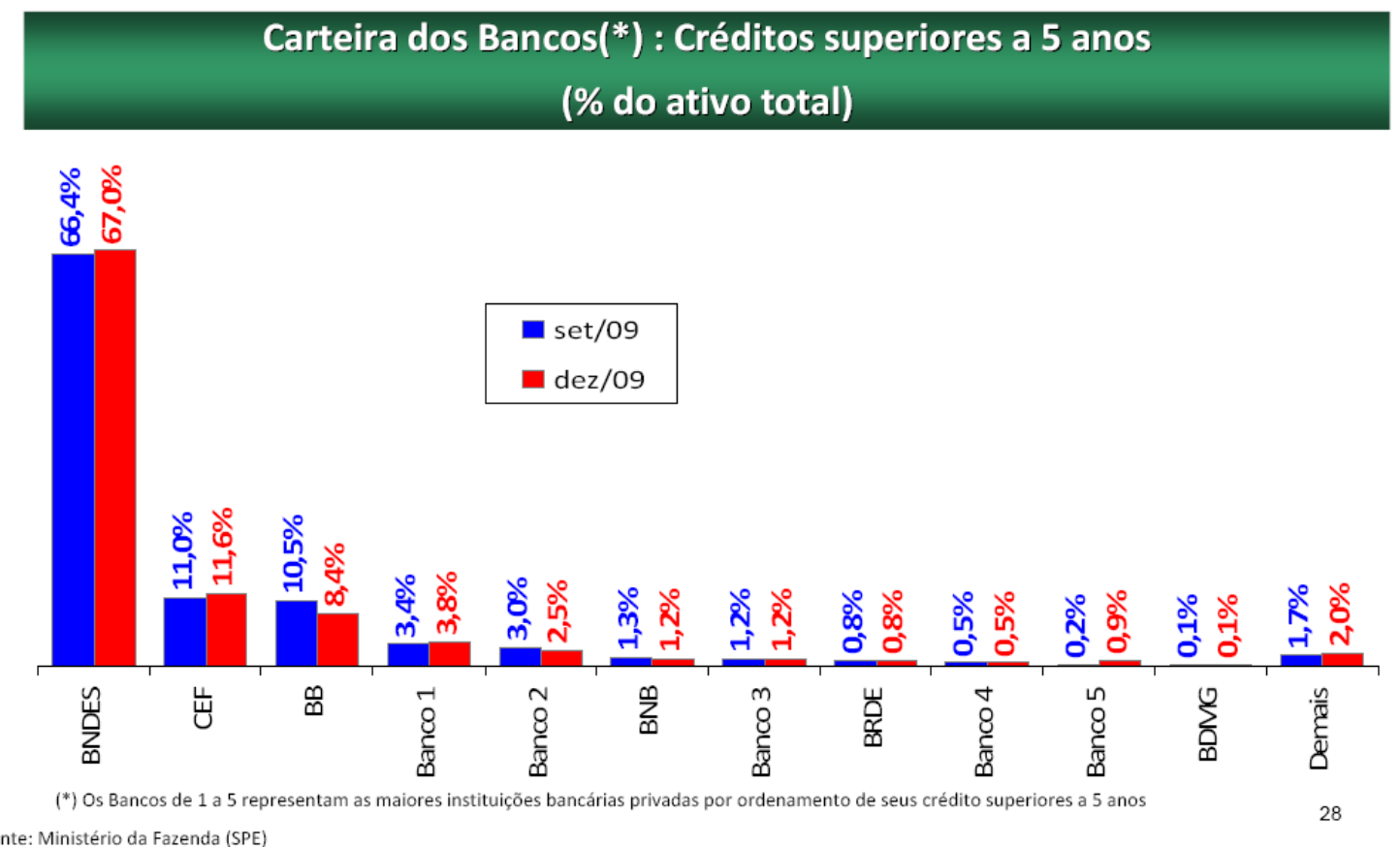

Fonte: BNDES/Ministério da Fazenda

Depreende-se que além de ser comparativamente reduzida a massa de crédito disponível, ela não se destina ao crédito de longo prazo a pessoas jurídicas, segmento de mercado muito dependente da atuação do BNDES. No entanto, o BNDES é um banco de desenvolvimento que não se utiliza da intermediação financeira para captação de recursos; o funding do BNDES é composto essencialmente por transferências diretas de recursos do Estado (42,5\%), pelo Fundo de Amparo ao Trabalhador (0,5\%) e pelo retorno das operações realizadas $(47,7 \%)^{148}$.

Como resultado, possível afirmar que o potencial dos bancos de multiplicar o capital e financiar as atividades produtivas por meio da intermediação financeira não tem sido potencializado no Brasil e canalizado para o financiamento do desenvolvimento. Ao contrário, os financiamentos produtivos no Brasil - diretamente relacionados ao

\footnotetext{
${ }^{148}$ Esses dados encontram-se disponíveis $\quad$ em http://www.bndes.gov.br/SiteBNDES/bndes/bndes_en/Institucional/Corporative_Governance/Sources_of_Fu nding/.
} 
desenvolvimento econômico - são amplamente dependentes da atuação do BNDES que, reitere-se, não se utiliza da intermediação financeira para a geração de crédito.

Dessa forma, um volume substantivo de capital gerado na economia permanece alocado em outras atividades. Veja-se, nesse sentido, os dados do BCB sobre o volume de capital disponível, que demonstram que o crédito financeiro - originado na atividade de intermediação financeira - é muito superior que aqueles disponível para atuação do BNDES, cujo funding independe dessa atividade:

Tabela IV - EVOLUÇÃO DO CRÉDTIO

\begin{tabular}{|lccc|}
\hline \multicolumn{4}{|c|}{ Evolução do Crédito (em bilhões de Reais) } \\
\hline & $\mathbf{2 0 0 8}$ & $\mathbf{2 0 0 9}$ & $\mathbf{2 0 1 0}$ \\
\hline Total & $1.227,3$ & $1.414,3$ & $1.705,8$ \\
\hline Recursos livres & 871,2 & 954,5 & $1.116,0$ \\
\hline Recursos direcionados & 356,1 & 459,8 & 589,6 \\
\hline $\begin{array}{l}\text { BNDES no total de recursos } \\
\text { direcionados }\end{array}$ & 209,3 & 283,0 & 357,8 \\
\hline
\end{tabular}

Fonte: BCB - Relatório de Economia Bancária e Crédito, 2010

Os dois problemas já identificados no sistema bancário brasileiro - pequeno volume de crédito em relação ao PIB e reduzida alocação do crédito disponível para atividades produtivas - são acompanhados ainda de outro problema: a concentração do crédito em determinadas regiões geográficas ${ }^{149}$.

A literatura pós-keynesiana explorada acima tem muitos de seus postulados confirmados no Brasil, um país com marcantes diferenças regionais, que se refletem também como fortes desigualdades financeiras. Pesquisas empíricas realizadas por autores distintos permitem a observação de uma tendência do sistema bancário brasileiro em concentrar o crédito na região mais desenvolvida, o Sudeste, especialmente no Estado de São Paulo.

\footnotetext{
${ }^{149}$ É evidente que há uma série de outras questões envolvendo o sistema bancário brasileiro e seu papel no desenvolvimento, como a questão do financiamento das atividades da micro e pequenas empresas. No entanto, o limitado escopo desse trabalho não permite que todos os pontos críticos dessa complexa relação sejam explorados. Para uma discussão lúcida sobre o papel do sistema financeiro no desenvolvimento brasileiro ver Barbara Stallings e Rogerio Studart, Finance for Development, op. cit., pp. 222 e ss.
} 
Utilizando dados do sistema SISBACEN do Banco Central e do IBGE, esses autores realizaram estudos empíricos com metodologias diversas e, em geral, puderam confirmar que a previsão da literatura pode ser aplicada ao Brasil: o sistema bancário, ao agir livremente, tende a concentrar o crédito nas regiões mais desenvolvidas, fazendo com que as regiões menos desenvolvidas sofram com a limitação do nível de crédito disponível. A literatura produzida sobre o caso brasileiro é extensa ${ }^{150}$; por isso, passa-se a uma síntese das principais evidências encontradas ${ }^{151}$.

As diferenças na preferência pela liquidez em São Paulo e no Sudeste, regiões centrais, em relação às demais regiões, tidas como periferia, são fundamentais para que o modelo teórico desenvolvido nos itens anteriores seja plausível no Brasil. Afinal, as diferentes preferências pela liquidez do lado da demanda e da oferta nas regiões do país é que determinam as variações no volume de crédito e sua concentração na região mais estável em razão dos vazamentos de recursos da periferia para o centro. Nesse sentido, indicadores construídos a partir de dados do balancete dos bancos múltiplos brasileiros disponibilizados pelo sistema SISBACEN procuram evidenciar a preferência pela liquidez dos bancos (PLB) e a preferência pela liquidez do público (PLP). Esses índices permitem que perceba se os agentes pretendem manter seus ativos mais ou menos líquidos.

O PLP é dado pela razão entre depósitos à vista e depósitos totais. O público decide entre as modalidades de depósito considerando o grau de incerteza, o volume de informações disponíveis na região e o nível de renda. Quanto maior o índice, mais liquidez é desejada (depósitos à vista são mais procurados) em razão da maior incerteza. Se o grau de incerteza se reduz, o índice pode se reduzir, pois ativos de menor liquidez passam a ser

\footnotetext{
${ }^{150}$ A literatura produzida sobre o Brasil é extensa e encontra sua base, essencialmente, em estudos de pesquisadores do Centro de Desenvolvimento e Planejamento Regional (CEDEPLAR) da Universidade Federal de Minas Gerais e nos estudos da Professora da Universidade de Brasília Adriana Amado, pioneira na discussão da relação entre sistema bancário e desenvolvimento regional no Brasil.

${ }^{151}$ As principais referências examinadas para este trabalho e que não são mencionados em notas específicas a seguir são: Marco Crocco e Claudia Barra, Moeda e espaço no Brasil: um estudo de áreas selecionadas, in Revista de Economia Política, vol. 24, n. 3 (2004): 386-403; Marco Crocco, Fabiana Santos e Pedro Amaral, The Spatial Structure of Financial Development in Brazil, UFMG/CEDEPLAR, Belo Hortizonte, 2009; Luiz Ricardo Mattos Teixeira Cavalcante. Sistema Financeiro no Brasil: aspectos regionais, disponível on-line in http://www.bnb.gov.br/; Lucas André Ajala Sorgato, Reynaldo Rubem Ferreira Jr., e Patrícia Rocha dos Santos, Concentração bancária e desigualdade regional: o caso do nordeste brasileiro, disponível on-line in http://www.bnb.gov.br/; Thaís Marzola Zara, Desenvolvimento financeiro, crescimento e desigualdade nos estados brasileiros, Dissertação de Mestrado, Faculdade de Economia, Administração e Contabilidade da Universidade de São Paulo, 2006.
} 
procurados. Já o PLB procura aferir o comportamento dos bancos, determinando se preferem manter consigo ativos mais líquidos ou realizar mais operações de crédito (que os deixam em situação de menor liquidez). O índice é constituído pela razão entre depósitos à vista e operações de crédito, de modo que quanto maior o índice maior a preferência pela liquidez, sendo o contrário verdadeiro.

No caso brasileiro, esses índices são consistentes com a teoria. Em Estados mais desenvolvidos, tanto PLP quanto PLB são inferiores aos indicadores nos Estados menos desenvolvidos, onde a preferência pela liquidez é maior. Regiões menos desenvolvidas contam com maior grau de incerteza, o que faz com que o público e os bancos prefiram manter ativos mais líquidos. Esse comportamento é verificado mesmo em dois períodos distintos, um sujeito a alta inflação (1988) e outro de estabilidade (1999). Por exemplo, em 1988, Roraima e Amapá apresentaram altos índices de PLP $(0,73 \%$ e 0,81\%, respectivamente) e PLB (1,34\% e 0,97\%), enquanto São Paulo e Rio de Janeiro apresentaram índices com valores opostos: PLP 0,11\% e 0,31\% e PLB 0,08\% e 0,04\%, respectivamente. Em 1999, essa diferenciação se mantém, ainda que tenha havido uma redução considerável na assimetria da preferência pela liquidez entre as regiões, possivelmente em razão do fim da crise inflacionária (PLP 0,41\%, e 0,39\%; PLB 0,66\% e 0,49\% para Roraima e Amapá. PLP 0,12\% e 0,14\%; PLB 0,10\% e 0,18\% para São Paulo e Rio de Janeiro) $)^{152}$.

Nessa linha, uma primeira evidência empírica importante encontrada pelos pesquisadores ao examinar dados do SISBACEN e do IBGE diz respeito à concentração do crédito na região Sudeste, com especial ênfase ao Estado de São Paulo (a região Sudeste e sobretudo São Paulo podem ser caracterizados como o centro financeiro no Brasil). Por ser esse Estado o mais desenvolvido da nação, seria de se esperar que o nível de crédito a ele destinado fosse mais substantivo. No entanto, chama atenção o fato de que essa concentração financeira se dá em patamar superior à concentração econômica, e vem aumentando ainda que a última se reduza.

152 Esses dados foram extraídos de Anderson Cavalcante, Marco Crocco e Frederico G. Jayme Jr., Preferência pela liquidez, sistema bancário e disponibilidade de crédito regional, op. cit., 2006, pp. 303-307. Esses autores apresentam ainda os índices para os demais Estados brasileiros. 
A tabela a seguir evidencia que, no período entre 1988 e 2000, São Paulo teve sua participação no PIB nacional reduzida (de $38 \%$ para $34 \%$ ) enquanto que sua participação no crédito bancário cresceu de $30 \%$ para $50 \%$. A concentração de depósitos, em linha com o crédito, é muito mais concentrada que a participação do Estado no PIB, isso a despeito de a proporção de agências acompanhar de perto a proporção do PIB. É interessante notar que isso se reflete nas demais regiões: a despeito de um número de agências proporcional ao PIB, as regiões Sul, Nordeste e Norte contam com proporções no total de depósitos e operações de crédito muito inferiores à sua participação no PIB. O caso do Centro-Oeste é peculiar por serem contabilizadas naquela região muitas operações do Banco do Brasil, da Caixa Econômica Federal e do Banco Central, ainda que realizadas em outros estados, o que resulta em uma superestimação da participação dessa região. 


\section{TABELA V - CRÉDITO E PIB POR REGIÕES}

\begin{tabular}{|c|c|c|c|c|c|c|c|c|c|c|c|c|c|}
\hline Ano & 88 & 89 & 90 & 91 & 92 & 93 & 94 & 95 & 96 & 97 & 98 & 99 & 2000 \\
\hline \multirow{2}{*}{\multicolumn{14}{|c|}{ SP }} \\
\hline & & & & & & & & & & & & & \\
\hline PIB & 38,1 & 37,8 & 37,0 & 35,3 & 35,5 & 34,9 & 34,1 & 35,5 & 34,9 & 35,5 & 35,5 & 34,9 & 33,7 \\
\hline Depósitos & 54,4 & 51,5 & 53,9 & 53,4 & 54,3 & 56,3 & 49,2 & 50,9 & 54,3 & 55,1 & 51,3 & 51,6 & 53,3 \\
\hline Operaçoes de Crédito & 30,3 & 34,9 & 37,0 & 36,7 & 40,4 & 43,0 & 47,7 & 46,1 & 55,3 & 42,8 & 48,5 & 48,6 & 50,0 \\
\hline Agências & 29,7 & 28,3 & 29,6 & 29,1 & 29,7 & 29,9 & 29,8 & 29,1 & 29,8 & 30,4 & 31,3 & 31,9 & 32,4 \\
\hline \multicolumn{14}{|l|}{$\mathbf{R J}$} \\
\hline PIB & 11,0 & 10,3 & 10,9 & 12,3 & 12,1 & 11,8 & 11,3 & 11,5 & 11,1 & 11,2 & 11,0 & 11,7 & 12,5 \\
\hline Depósitos & 11,5 & 13,8 & 10,8 & 10,8 & 13,2 & 12,8 & 11,8 & 13,0 & 12,9 & 10,9 & 11,4 & 11,1 & 9,8 \\
\hline Operaçoes de Crédito & 25,4 & 25,4 & 20,3 & 20,9 & 18,4 & 17,6 & 9,2 & 8,9 & 5,9 & 9,8 & 8,6 & 9,3 & 9,3 \\
\hline Agências & 7,9 & 8,0 & 8,2 & 8,5 & 8,5 & 8,5 & 8,5 & 8,4 & 8,5 & 8,7 & 8,9 & 9,2 & 9,5 \\
\hline \multicolumn{14}{|l|}{ MG/ES } \\
\hline PIB & 11,2 & 11,3 & 11,0 & 11,2 & 11,2 & 11,1 & 11,8 & 11,7 & 12,0 & 11,9 & 11,7 & 11,6 & 11,6 \\
\hline Depósitos & 7,5 & 6,1 & 7,7 & 7,6 & 8,7 & 9,3 & 8,6 & 5,3 & 4,8 & 5,3 & 5,8 & 6,7 & 6,2 \\
\hline Operaçoes de Crédito & 6,7 & 7,0 & 7,0 & 6,1 & 6,2 & 6,3 & 7,2 & 6,2 & 5,1 & 6,9 & 5,9 & 6,2 & 6,3 \\
\hline Agências & 13,1 & 12,8 & 13,4 & 11,6 & 11,5 & 11,5 & 12,3 & 12,7 & 12,9 & 12,9 & 12,9 & 12,7 & 12,6 \\
\hline \multicolumn{14}{|l|}{ Região Sul } \\
\hline PIB & 17,5 & 18,6 & 18,2 & 17,1 & 18,3 & 18,4 & 18,7 & 17,9 & 18,0 & 17,7 & 17,5 & 17,7 & 17,6 \\
\hline Depósitos & 12,4 & 13,1 & 11,4 & 10,6 & 8,4 & 8,3 & 9,7 & 10,6 & 8,9 & 10,0 & 12,2 & 10,6 & 10,0 \\
\hline Operaçoes de Crédito & 12,8 & 12,5 & 12,2 & 12,3 & 12,6 & 11,8 & 13,8 & 14,7 & 13,4 & 12,7 & 13,1 & 12,6 & 12,2 \\
\hline Agências & 19,9 & 20,9 & 20,6 & 21,4 & 21,3 & 21,3 & 21,1 & 21,4 & 21,0 & 20,6 & 21,1 & 20,9 & 20,6 \\
\hline \multicolumn{14}{|l|}{ Região Nordes te } \\
\hline PIB & 12,8 & 12,3 & 12,9 & 13,4 & 12,9 & 12,8 & 12,9 & 12,8 & 13,2 & 13,1 & 13,1 & 13,1 & 13,1 \\
\hline Depósitos & 5,8 & 5,0 & 7,3 & 7,8 & 7,8 & 6,8 & 6,4 & 5,1 & 10,0 & 7,6 & 7,0 & 7,2 & 7,2 \\
\hline Operaçoes de Crédito & 8,1 & 7,7 & 10,2 & 9,6 & 9,3 & 8,4 & 9,6 & 10,7 & 8,7 & 13,6 & 9,6 & 9,0 & 8,2 \\
\hline Agências & 17,6 & 17,7 & 16,7 & 16,5 & 16,5 & 16,3 & 16,0 & 16,1 & 15,8 & 15,4 & 14,8 & 14,5 & 14,2 \\
\hline \multicolumn{14}{|l|}{ Região Centro-Oeste } \\
\hline PIB & 5,0 & 4,8 & 5,2 & 6,1 & 5,7 & 5,8 & 6,1 & 6,0 & 6,1 & 6,2 & 6,8 & 6,4 & 7,0 \\
\hline Depósitos & 7,5 & 10,1 & 7,9 & 8,8 & 6,7 & 5,8 & 13,4 & 14,0 & 8,2 & 9,9 & 11,1 & 11,2 & 12,1 \\
\hline Operaçoes de Crédito & 15,6 & 11,8 & 12,4 & 12,9 & 11,8 & 11,5 & 11,2 & 12,1 & 8,1 & 12,3 & 12,5 & 12,8 & 12,7 \\
\hline Agências & 7,6 & 8,0 & 7,7 & 8,2 & 8,2 & 8,2 & 8,2 & 8,2 & 8,0 & 8,0 & 7,5 & 7,4 & 7,3 \\
\hline \multicolumn{14}{|l|}{ Região Norte } \\
\hline PIB & 4,4 & 4,9 & 4,9 & 4,7 & 4,3 & 5,2 & 5,1 & 4,6 & 4,6 & 4,4 & 4,5 & 4,4 & 4,6 \\
\hline Depósitos & 0,8 & 0,5 & 1,0 & 1,1 & 0,9 & 0,8 & 0,9 & 1,0 & 1,0 & 1,2 & 1,2 & 1,5 & 1,5 \\
\hline Operaçoes de Crédito & 1,0 & 0,9 & 1,0 & 1,4 & 1,3 & 1,3 & 1,3 & 1,2 & 3,6 & 1,9 & 1,9 & 1,5 & 1,4 \\
\hline Agências & 4,3 & 4,3 & 4,3 & 4,3 & 4,2 & 4,2 & 4,2 & 4,1 & 4,0 & 3,9 & 3,5 & 3,5 & 3,4 \\
\hline
\end{tabular}

Fonte: Elaborado por Michel Alexandre, Gilberto Tadeu Lima e Otaviano Canuto, a partir de dados do IBGE e do SISBACEN ${ }^{153}$.

Esses dados são corroborados pela verificação de que a concentração geográfica das atividades financeiras no Sudeste é superior à concentração das demais atividades econômicas. Assim, a previsão da teoria no sentido de que um sistema bancário baseado

\footnotetext{
${ }^{153}$ Determinantes das decisões locacionais da atividade financeira, in Nova Economia 16 (2006), p. 249
} 
em grandes bancos nacionais tende à concentração bancária, uma vez que permite o vazamento de recursos, é confirmada no Brasil. O movimento natural do mercado leva à concentração do crédito na região central -mais desenvolvida economicamente - em razão da maior estabilidade e menor incerteza, que reduzem a preferência pela liquidez nessa região. Consequentemente, as empresas localizadas no Sudeste, e sobretudo em São Paulo, têm acesso ao crédito com maior facilidade e podem contar com instrumentos bancários diversificados. Além disso, a industrialização no Brasil se deu majoritariamente com base na instalação de filiais das matrizes de São Paulo ou do Sudeste nas regiões periféricas, o que incrementa o vazamento de depósitos para o centro, uma vez que as operações de crédito são concentradas nas sedes das empresas e dos bancos, onde as decisões sobre investimento são tomadas.

\section{TABELA VI - CONCENTRAÇÃO DE CRÉDITO E ECONÔMICA}

\begin{tabular}{|c|c|c|c|c|c|c|c|c|}
\hline \multirow[b]{2}{*}{ B rasil } & \multicolumn{2}{|c|}{1998} & \multicolumn{2}{|c|}{1999} & \multicolumn{2}{|c|}{2000} & \multicolumn{2}{|c|}{2001} \\
\hline & $\begin{array}{c}\text { Total das } \\
\text { Atividades }\end{array}$ & $\begin{array}{c}\text { Inte rme diação } \\
\text { Financeira }\end{array}$ & $\begin{array}{c}\text { Total das } \\
\text { Atividades }\end{array}$ & $\begin{array}{c}\text { Inte rme diação } \\
\text { Financeira }\end{array}$ & $\begin{array}{c}\text { Total das } \\
\text { Atividades }\end{array}$ & $\begin{array}{c}\text { Inte rme diação } \\
\text { Financeira }\end{array}$ & \begin{tabular}{|c} 
Total das \\
Atividades
\end{tabular} & $\begin{array}{l}\text { Inte rme diação } \\
\text { Financeira }\end{array}$ \\
\hline$\widehat{\text { Norte }}$ & 4,5 & 1,5 & 4,5 & 1,6 & 4,6 & 1,9 & 4,7 & 1,7 \\
\hline Rondônia & 0,5 & 0,1 & 0,5 & 0,1 & 0,5 & 0,2 & 0,5 & 0,2 \\
\hline Acre & 0,2 & 0,0 & 0,2 & 0,0 & 0,2 & 0,1 & 0,2 & 0,1 \\
\hline Amazonas & 1,6 & 0,4 & 1,6 & 0,4 & 1,7 & 0,5 & 1,7 & 0,4 \\
\hline Roraima & 0,1 & 0,0 & 0,1 & 0,0 & 0,1 & 0,0 & 0,1 & 0,0 \\
\hline Pará & 1,7 & 0,8 & 1,8 & 0,9 & 1,8 & 0,9 & 1,8 & 0,8 \\
\hline Amapá & 0,2 & 0,0 & 0,2 & 0,0 & 0,2 & 0,1 & 0,2 & 0,0 \\
\hline Tocatins & 0,2 & 0,1 & 0,2 & 0,1 & 0,2 & 0,2 & 0,2 & 0,2 \\
\hline Nordeste & 13,1 & 7,3 & 13,1 & 7,0 & 13,0 & 7,8 & 13,0 & 7,9 \\
\hline Maranhão & 0,8 & 0,3 & 0,8 & 0,3 & 0,8 & 0,5 & 0,9 & 0,5 \\
\hline Piauí & 0,5 & 0,1 & 0,5 & 0,1 & 0,5 & 0,3 & 0,5 & 0,3 \\
\hline Ceará & 2,1 & 1,4 & 2,0 & 1,4 & 1,9 & 1,3 & 1,8 & 1,5 \\
\hline Rio Grande do Norte & 0,7 & 0,4 & 0,8 & 0,5 & 0,8 & 0,4 & 0,8 & 0,4 \\
\hline Paraíba & 0,8 & 0,2 & 0,8 & 0,2 & 0,8 & 0,4 & 0,9 & 0,5 \\
\hline Pernambuco & 2,7 & 1,2 & 2,7 & 1,2 & 2,6 & 1,6 & 2,6 & 1,5 \\
\hline Alagoas & 0,7 & 0,3 & 0,7 & 0,3 & 0,6 & 0,4 & 0,6 & 0,4 \\
\hline Sergipe & 0,6 & 0,2 & 0,5 & 0,2 & 0,5 & 0,4 & 0,7 & 0,4 \\
\hline Bahia & 4,2 & 3,1 & 4,3 & 2,9 & 4,3 & 2,5 & 4,3 & 2,3 \\
\hline Sudeste & 57,7 & 61,6 & 57,8 & 64,1 & 57,5 & 66,1 & 57,2 & 69,0 \\
\hline Minas Gerais & 9,8 & 5,4 & 9,6 & 6,0 & 9,7 & 6,0 & 9,4 & 6,0 \\
\hline Espírito Santo & 1,7 & 0,5 & 1,8 & 0,5 & 1,8 & 1,2 & 1,7 & 1,0 \\
\hline Rio de Janeiro & 11,0 & 10,0 & 11,8 & 10,8 & 12,7 & 10,9 & 12,5 & 10,0 \\
\hline São Paulo & 35,3 & 45,7 & 34,7 & 46,8 & 33,3 & 48,0 & 33,6 & 52,0 \\
\hline Sul & 17,6 & 11,6 & 17,9 & 12,1 & 17,6 & 13,2 & 17,8 & 12,4 \\
\hline Paraná & 6,3 & 4,9 & 6,4 & 5,0 & 6,0 & 5,3 & 6,1 & 5,1 \\
\hline Santa Catarina & 3,5 & 1,1 & 3,6 & 1,1 & 3,8 & 2,0 & 3,9 & 2,0 \\
\hline Rio Grande do Sul & 7,8 & 5,6 & 7,8 & 6,0 & 7,8 & 5,9 & 7,9 & 5,4 \\
\hline \begin{tabular}{|l|} 
Centro-Oeste \\
\end{tabular} & 7,1 & 17,9 & 6,8 & 15,2 & 7,2 & 11,1 & 7,3 & 9,0 \\
\hline Mato Grosso do Sul & 1,1 & 0,6 & 1,1 & 0,6 & 1,1 & 0,6 & 1,1 & 0,6 \\
\hline Mato Grosso & 1,1 & 0,5 & 1,2 & 0,5 & 1,2 & 0,8 & 1,2 & 0,8 \\
\hline Goiás & 1,9 & 1,0 & 1,8 & 0,9 & 1,9 & 1,4 & 2,0 & 1,3 \\
\hline Distrito Federal & 3,0 & 15,8 & 2,7 & 13,2 & 3,0 & 8,3 & 2,9 & 6,4 \\
\hline
\end{tabular}

Fonte: Elaborado por Melissa Menezes et al, a partir de dados do IBGE e do SISBACEN ${ }^{154}$

\footnotetext{
${ }^{154}$ Sistema financeiro e desenvolvimento regional: notas exploratórias, op.cit., pp. 295-296.
} 
A análise da evolução desses dados nos anos 2000 indica que as reformas no mercado bancário na década de 1990 levaram a um agravamento da concentração regional do crédito. Esse período foi marcado por intensa concentração bancária, incentivada pelos programas estatais de saneamento do setor bancário, como o PROER (Programa de Estímulo à Reestruturação e ao Fortalecimento do Sistema Financeiro Nacional) e o PROES (Programa de Incentivo à Redução da Presença do Estado na Atividade Bancária), que levaram à incorporação de várias instituições com atuação regional por bancos de âmbito nacional e com sede no centro, ou cuja atuação fosse focada no centro-sul. A quase eliminação dos bancos regionais acentuou as restrições financeiras nas regiões periféricas: "é absolutamente lógico pensar que o processo de concentração levará os bancos que assumem os bancos regionais a redirecionarem suas atividades para regiões que possuem vantagens comparativas: regiões centrais. "155

Em 1994, o Sudeste concentrava 62,5\% do crédito concedido no país, enquanto que em 2006 essa proporção era de 70,2\%, tendo chegado a 74,3\% em 2002. O Estado de São Paulo recebeu 38,3\% do crédito em 1994 e 57,3\% em 2006. De outro lado, em 2006, apenas $29,3 \%$ do crédito foi repartido entre os outros 23 estados brasileiros, representando, em média, apenas $1,3 \%$ para cada Estado fora da região sudeste ${ }^{156}$. Os mapas abaixo corroboram a constatação de que a concentração de crédito é mais acentuada que a concentração econômica e que, enquanto a última se reduziu, a primeira se intensificou:

\footnotetext{
${ }^{155}$ Adriana Amado, Impactos regionais do processo de reestruturação bancária do início dos anos 1990, in Marco Crocco e Frederico Jayme Jr., Moeda e território, op. cit., p. 163.

${ }^{156}$ Dados extraídos de Ana Paula Gonçalves de Freitas e Luis Fernando Rodrigues de Paula, Concentração regional do crédito e consolidação bancária no Brasil: uma análise pós-real, in Revista EconomiA, vol. 11, n.1 (2010), p. 108. Esses autores apresentam tabela com os dados anuais, de 1994 a 2006, para todos os Estados separadamente.
} 

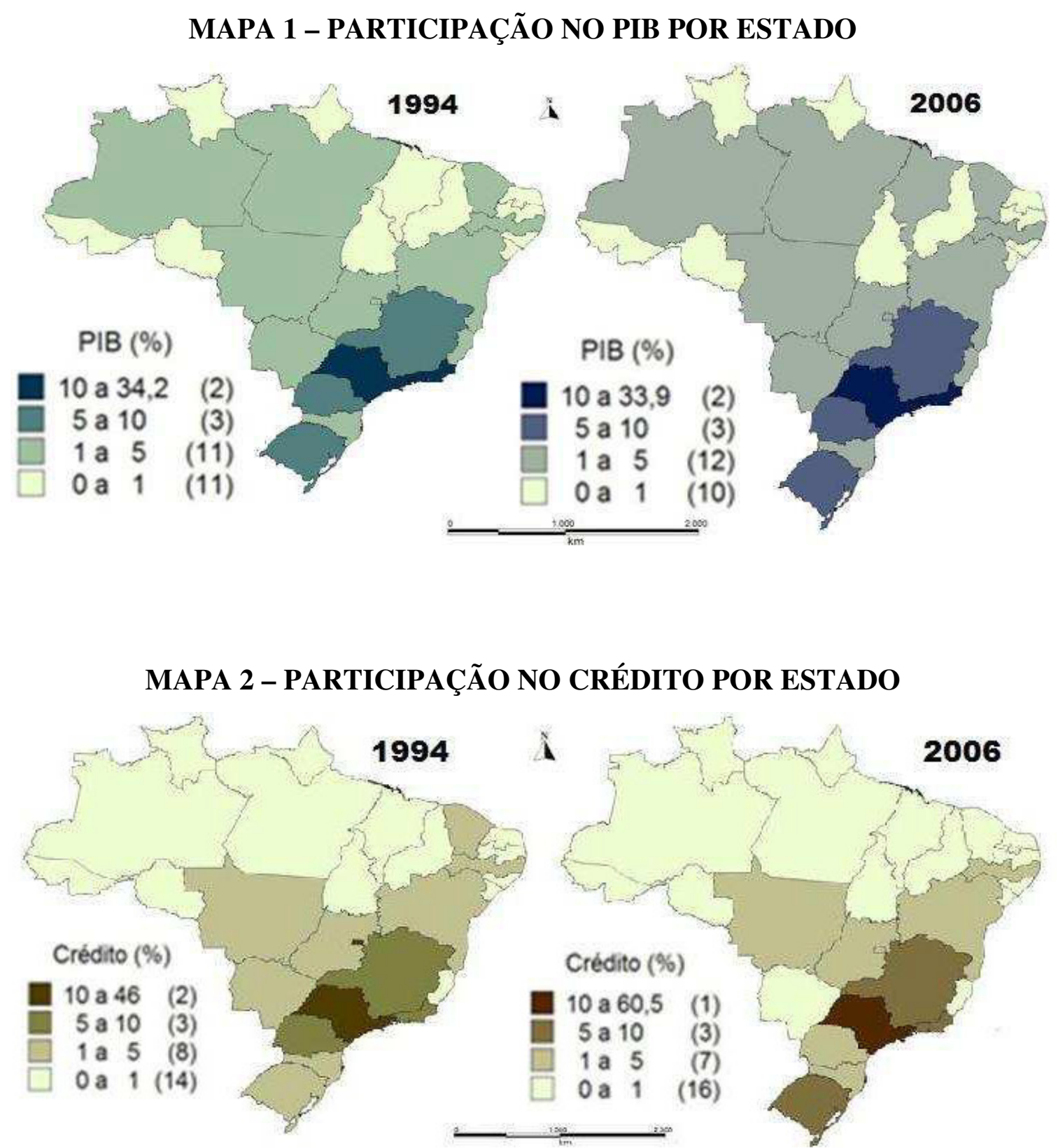

Fonte: Elaborado por Ana Paula Gonçalves de Freitas e Luis Fernando Rodrigues de Paula, a partir de dados do IBGE ${ }^{157}$.

Exercícios econométricos variados foram realizados. Em síntese, eles confirmaram diversos dos pressupostos da teoria, demonstrando: (i) uma relação negativa entre oferta de crédito e preferência pela liquidez dos bancos e uma relação positiva entre o número de

\footnotetext{
${ }^{157}$ Concentração regional do crédito e consolidação bancária no Brasil: uma análise pós-real, op. cit., p.
} 111. 
agências e a disponibilidade de crédito $^{158}$; (ii) regiões centrais têm maior capacidade de gerar crédito, enquanto regiões periféricas encontram mais dificuldades ${ }^{159}$; (iii) tanto a demanda quanto a oferta de crédito em regiões menos desenvolvidas são menores do que as observadas em regiões com maior potencial econômico, o que se justificaria pela maior preferência pela liquidez dos bancos e do público nas regiões periféricas ${ }^{160}$; (iv) o aumento dos depósitos em determinado Estado incrementa sua participação no total do crédito ${ }^{161}$.

Vale ressaltar, por fim, que a situação macroeconômica nacional, marcada por uma política monetária baseada em altas taxas de juros, não apenas encarece o crédito e elimina um mercado de crédito de longo prazo como reforça a concentração do crédito em regiões centrais, aumentando as disparidades regionais. Isso porque a alta taxa de juros dos títulos públicos "acostuma” os bancos com operações de alto retorno e baixíssimo grau de risco. Essa aversão ao risco e maior preferência pela liquidez se reflete com mais vigor sobre as regiões periféricas. Os recursos não destinados aos títulos públicos tendem a se concentrar no centro, onde o risco é menor ${ }^{162}$.

\subsection{A regulação estatal como elemento exógeno e capaz de reverter a lógica da desigualdade}

Diferentemente do que defendido pela ortodoxia econômica, os autores póskeynesianos identificam a necessidade de intervenção do estado por meio da política monetária e regulação financeira para que a desigualdade regional seja atenuada ${ }^{163}$. Uma

\footnotetext{
${ }^{158}$ Cf. Melissa Menezes et. al., Sistema financeiro e desenvolvimento regional: notas exploratórias, op. cit., pp. 300-303 e Ana Paula Gonçalves de Freitas e Luis Fernando Rodrigues de Paula, Concentração regional do crédito e consolidação bancária no Brasil: uma análise pós-real, op. cit., p. 119.

${ }^{159}$ Cf. Marco Crocco et. al, Polarização regional e sistema financeiro, in Marco Crocco e Frederico Jayme Jr., Moeda e território, op. cit., pp. 231-269.

${ }_{160}$ Anderson Cavalcante, Marco Crocco e Frederico G. Jayme Jr., Preferência pela liquidez, sistema bancário e disponibilidade de crédito regional, op. cit., pp. 295-316.

${ }^{161}$ Cf. Ana Paula Gonçalves de Freitas e Luis Fernando Rodrigues de Paula, Concentração regional do crédito e consolidação bancária no Brasil: uma análise pós-real, op. cit., p. 119.

${ }^{162}$ Cf. Anderson Cavalcante, Marco Crocco e Frederico G. Jayme Jr., Preferência pela liquidez, sistema bancário e disponibilidade de crédito regional, op. cit., p. 310.

${ }^{163}$ A atuação direta através de bancos de desenvolvimento ou bancos regional também pode ser relevante. No entanto, ela não evitaria que a substantiva massa de recursos detida pelas instituições privadas continuasse a perpetuar o ciclo de desigualdade.
} 
série de instrumentos e reformas podem ser pensadas a partir desse ferramental, sendo as mais usualmente apontadas descritas a seguir ${ }^{164}$.

Diante do problema econômico identificado, autores pós-keynesianos têm sugerido a necessidade de intervenção do Estado sobre o sistema bancário. O Estado seria um elemento exógeno (externo) ao sistema e, por isso, não sujeita à lógica dos entes privados compreendidos no modelo. Dessa forma, o Estado é visto como uma força externa a contribuir para o rompimento dos círculos viciosos descritos ${ }^{165}$. Essa atuação poderia se dar em duas frentes principais, envolvendo a ação das autoridade monetárias: política monetária regionalmente diferenciada e intervenção regulatória sobre a estrutura do sistema financeiro.

$\mathrm{Na}$ dimensão da política monetária, diferencias regionais na fixação de depósitos compulsórios ou taxas de redesconto são usualmente apontadas como instrumentos relevantes e que já foram utilizados em diversos países, inclusive no Brasil. Outra possibilidade seria a escolha de regiões periféricas para a expansão da base monetária em patamares diferenciados.

Por sua vez, a regulação financeira poderia incentivar bancos regionais, limitando a atuação dos bancos fora de suas regiões de origem ${ }^{166}$, ou determinar que a contabilidade bancária fosse estruturada de modo a refletir as contas de cada região, para que os vazamentos de crédito pudessem ser identificados e desincentivados ${ }^{167}$. Algum nível de direcionamento de crédito poderia existir, especialmente para que empreendimentos em regiões periféricas fossem incentivados e empresas locais pudessem se desenvolver (pois empresas nacionais tendem a apresentar vazamentos de recursos para o centro, onde suas matrizes estão localizadas).

\footnotetext{
${ }^{164}$ Cf. Adriana Amado, Moeda, financiamento, sistema financeiro e trajetórias de desenvolvimento regional desigual: a perspectiva pós-keynesiana, in Revista de Economia Política, vol 18, n. 1 (1998), pp. 86-88.

${ }^{165} \mathrm{Cf}$. Adriana Amando, A questão regional e o sistema financeiro: uma interpretação pós-keynesiana, in Estudos Econômicos, v. 27, n.3 (1997), p. 434.

${ }^{166}$ Esse tipo de limitação, por exemplo, é aplicada nos Estados Unidos, onde o sistema bancário regional é bem desenvolvido. A regulamentação existente é tanto federal quanto estadual e visa limitar a atuação em dos bancos em diversos estados. No entanto, essas limitações vêm sendo atenuadas, como anotam Michel Alexandre, Gilberto Tadeu Lima e Otaviano Canuto, Determinantes das decisões locacionais da atividade financeira, in Nova Economia 16 (2006), p. 249.

167 A publicação de balanços discriminando as atividades por região foi adotada no Canadá, a partir da década de 1970, conforme relatado em Sheila Dow, Money and Regional Development, op. cit, p. 155.
} 
A ação de bancos públicos regionais ou de desenvolvimento também pode contribuir. No entanto, este trabalho concentra-se em iniciativas que procuram incentivar o setor privado a estender o crédito regionalmente, posto que, como discutido acima, a massa de recursos de que dispõe o sistema financeiro privado é muito substantiva em razão da intermediação financeira. Em outras palavras, ainda que ações do BNDES ou de bancos regionais como o Banco do Nordeste possam ser pensadas e sejam relevantes para o desenvolvimento regional, este trabalho procura apontar a necessidade de reflexão acerca de alternativas para que a intermediação financeira (eminentemente realizada pelo setor privado) e sua capacidade de geração de recursos sejam melhor exploradas para o desenvolvimento do país.

Por fim, a necessidade de coordenação de iniciativas relativas ao setor financeiro com a política industrial é sempre lembrada. A reestruturação regional da política monetária e da regulação financeira para destinar recursos às regiões periféricas apenas será relevante no longo prazo se esses recursos se mantiverem na região, mediante a estruturação de projetos de desenvolvimento, o que contribui para a redução dos vazamentos e gradual diminuição na assimetria entre as preferências pela liquidez nas diferentes regiões geográficas.

Essas possíveis medidas precisam ser examinadas com maior detalhamento e testadas na prática. Diversas ferramentas podem ser pensadas para tratar desse problema. No entanto, não é objetivo deste trabalho debater detalhadamente as possíveis ferramentas ou soluções que a autoridade monetária poderia adotar. Esse debate é necessário e deve ser interdisciplinar, compreendendo economistas e juristas, mas compreende um passo adiante em relação ao estágio em que nos encontramos.

O ponto central deste trabalho é justamente demonstrar que debater essas ferramentas e possíveis políticas que tratem do setor bancário e do desenvolvimento regional é fundamental, pois o problema regional e sua relação com o sistema bancário e a moeda não pode ser ignorado. Esse problema exige ação do Estado e isso foi reconhecido pelo direito, que conferiu às autoridades monetárias mandato específico para disciplina dessas questões. 
Assim, o próximo item dedica-se a demonstrar que a questão do desenvolvimento regional e o papel do sistema financeiro foram disciplinados pelo ordenamento jurídico brasileiro, que alçou a redução da desigualdade regional como uma das metas das autoridades monetária no Brasil, conferindo instrumentos para que esse objetivo seja alcançado. 


\section{A QUESTÃO JURÍDICA: AUTORIDADE MONETÁRIA E ORDEM JURÍDICA NO BRASIL}

O cenário exposto até aqui evidencia uma tensão entre a realidade de um país em desenvolvimento como o Brasil, em que há consideráveis e consistentes disparidades regionais que são perpetuadas e intensificadas pela concentração de crédito bancário, em relação ao que se propaga como best practice internacionalmente como papel da autoridade monetária - exclusivamente a manutenção da estabilidade de preços e da higidez do sistema financeiro. A questão que se propõe objetiva definir se esse papel "minimalista" é adequado para a autoridade monetária brasileira diante da realidade do país e de seu ordenamento jurídico.

Até meados do século $\mathrm{XX}$, o Brasil não contava com uma autoridade monetária com as funções usualmente exercidas contemporaneamente, seja na forma de banco central ou de outra entidade. Na verdade, a evolução da intervenção do Estado brasileiro sobre a disciplina monetária e do crédito teve início com a chegada da família real portuguesa ao território da então colônia em 1808, e tinha um propósito muito semelhante àquele verificado na experiência europeia de evolução dos bancos centrais: financiamento das despesas públicas. Criou-se então o Banco do Brasil, um banco comercial que tinha desde sua origem como papel fundamental financiar os gastos do reino.

O Banco do Brasil assumiu o papel de autoridade monetária até $1945^{168}$, agregando as funções de emissão de moeda, agente financeiro do Tesouro Nacional, banco de financiamento agrícola e de desenvolvimento, banco comercial e gestor da política cambial. Essa ampla gama de prerrogativas garantia à instituição um papel representativo no cenário político nacional, especialmente porque o Banco atuava como financiador direto do Tesouro Nacional por meio da emissão de moeda.

Após tentativas frustradas de organização de uma autoridade monetária como funções mais delimitadas e que não fosse, ao mesmo tempo, também um banco comercial, em 1945 iniciou-se o debate para o desenvolvimento de um projeto de banco central no

${ }^{168}$ Uma síntese da evolução histórica pode ser encontrada em Jairo Saddi, O poder e o cofre - repensando o Banco Central, op. cit., pp. 171-74. Destaque-se que esse autor apresenta importantes referências bibliográficas para um estudo mais detido desse ponto. 
sentido mais estrito e atual do termo. Esse debate ganhou força em face do processo inflacionário que se instalou no pós-guerra, tornando necessária uma disciplina mais rigorosa para a emissão de papel moeda e regulamentação dos bancos.

Nesse contexto, foi criada a Superintendência da Moeda e do Crédito - SUMOC, por meio do Decreto-Lei 7.293, "com o objetivo imediato de exercer o controle do mercado monetário e de preparar a organização do Banco Central ${ }^{169}$. Esse período de duas décadas, até 1964, pode ser compreendido como uma fase de preparação para criação de um banco central, sendo marcado pela atuação do Banco do Brasil no sentido de exercer pressão política contrária à criação de um banco central, visando a manutenção de suas prerrogativas $^{170}$.

A pressão exercida pela secular burocracia do Banco do Brasil resultou em uma solução "mista", segundo a qual o Banco do Brasil continuaria desempenhando o duplo papel de banco comercial e de autoridade monetária, que passava a ser compartilhada com a própria Sumoc. Importante notar que o Banco do Brasil preservou seus poderes sobre a moeda e o crédito, enquanto a SUMOC nunca dispôs de controle efetivo sobre os instrumentos de política monetária. Assim, apesar de esforços da SUMOC no sentido de controlar as contas do Banco do Brasil, "a eficácia operacional da superintendência nesta área de controle monetário e creditício foi extremamente limitada ao longo da década de $1950^{\prime \prime 171}$, sendo sua atuação de maior relevância nas áreas de regulamentação do setor bancário, política cambial e comércio exterior.

\footnotetext{
${ }^{169}$ Alberto Venâncio Filho, A intervenção do Estado no domínio econômico, op. cit., p. 277. A respeito é importante notar que "sua criação foi proposta em 1944 pelo professor Otávio Gouveia de Bulhões ao ministro da Fazenda Artur de Sousa Costa, como instituição que constituiria o embrião do futuro Banco Central do Brasil. Se este era o objetivo fundamental a alcançar a médio prazo - na verdade, a transição da Sumoc para o Banco Central demandaria duas décadas —, havia dois objetivos mais imediatos. $O$ primeiro dizia respeito à tentativa de coordenação das políticas monetária e creditícia, em particular de controle seletivo do crédito estendido pelo Banco do Brasil, e o segundo ligava-se à necessidade, tal como vista por Bulhões, de um interlocutor técnico privilegiado com as instituições financeiras internacionais criadas em Bretton Woods, nos Estados Unidos, em 1944, e destinadas a supervisionar, sob a hegemonia norte-americana, a ordem econômica internacional do pós-guerra. Assim é que, tão logo criada, a Sumoc foi feita representante do governo junto ao Fundo Monetário Internacional (FMI) e ao Banco Mundial, passando a manter relações estreitas com estas entidades e a adotar as medidas necessárias para dar cumprimento à Convenção de Bretton Woods, ratificada pelo governo brasileiro." (Pedro Malan, Verbete: Superintendência da Moeda e do Crédito (SUMOC), in Dicionário Histórico Bibliográfico Brasileiro do Centro de Pesquisa e Documentação de História Contemporânea do Brasil da Fundaçào Getúlio Vargas, disponível on-line in www.cpdoc.fgv.br).

${ }^{170}$ Nesse sentido, o relato de Sidnei Turczyn, O Sistema Financeiro Nacional e a regulação bancária, São Paulo: Revista dos Tribunais, 2005, p. 129.

${ }^{171}$ Pedro Malan, Verbete: Superintendência da Moeda e do Crédito (SUMOC), op. cit.
} 
Este caráter dual da autoridade monetária, marcado pela força do Banco do Brasil, reverberou ainda quando da criação do Banco Central pela Lei 4.595/64. Essa Lei marca a criação formal de um Banco Central do Brasil (com a consequente extinção da SUMOC) mas, inicialmente, não representava ainda a construção no país de uma instituição com as funções e características indicados pela experiência internacional no século XX como típicas de um banco central.

A criação do BCB foi marcada pela reação na esfera política do poderoso Banco do Brasil, que conseguiu manter consigo diversas das atribuições mais relevantes, dentre elas a de agente do Tesouro Nacional, de agente das políticas oficiais de crédito do Governo Federal e de recebedor dos depósitos voluntários do sistema bancário. Ao BCB havia se atribuído apenas a prerrogativa de receber os empréstimos compulsórios das instituições bancárias.

No entanto, a transferência das reservas compulsórias ao BCB significava a perda pelo Banco do Brasil de uma fonte expressiva de recursos. Para compensar essa perda e em função de sua vasta rede de agências, o Banco do Brasil foi designado como órgão executor das políticas do BCB, sendo criada uma conta especial, posteriormente conhecida como "conta movimento", para o registro das transações entre as duas instituições. A conta deveria, formalmente, ser "zerada" semanalmente com o pagamento de $1 \%$ de juros sobre o saldo, mas isto nunca ocorreu. Na prática, a conta movimento garantia recursos do BCB ao Banco do Brasil de forma imediata e sem limites, para que o último pudesse atender à política de concessão de crédito do Governo Federal $^{172}$.

Com livre acesso a esses recursos, o Banco do Brasil atuava como um banco comercial que se encontrava livre das restrições impostas pela relação encaixe/depósito para a geração de crédito. De outro lado, o BCB reiteradamente emitia moeda para geração

\footnotetext{
${ }^{172}$ Pedro Malan explica que "a conta deveria teoricamente ser "zerada" semanalmente com o pagamento de $1 \%$ de juros sobre o saldo. Isto, na verdade, nunca ocorreu. A conta de movimento ajustou-se sempre passivamente à transferência de recursos para o Banco do Brasil, tal como requerida para que este cumprisse as metas de empréstimos estabelecidas pelo governo através do Conselho Monetário. Em 31 de dezembro de 1981, o valor da conta de movimento era igual ao da base monetária, cerca de $50 \%$ do total dos meios de pagamentos. Figurando no ativo do Banco Central e no passivo do Banco do Brasil, a conta de movimento desaparece quando se apresenta o balancete consolidado das autoridades monetárias, que incluem Banco Central e Banco do Brasil." (Verbete: Superintendência da Moeda e do Crédito, op. cit.)
} 
desse recursos a serem destinados ao Banco do Brasil, ampliando a base monetária (o valor da conta movimento era o mesmo de toda a base monetária em 1981) ${ }^{173}$ e consolidando um evidente viés inflacionário.

Além do caráter inflacionário da política de crédito do governo federal em razão de sua relação direta com a conta movimento, o governo passou a lançar mão com maior intensidade da emissão de moeda para fins de financiar a dívida pública. $\mathrm{O}$ orçamento monetário, previsto no art. 4, III, da Lei 4.594/64, com o fim de criar uma programação do aumento da base monetária e limitar a discricionariedade do $\mathrm{BCB}$, passou a ser utilizado como um componente de peso no orçamento fiscal do Estado. A expansão da base monetária se tornou uma fonte de recursos atrativa para o governo, já que independia da tributação e não passava pelo controle do Poder Legislativo.

Dessa forma, a peculiar organização das instituições monetárias e suas atribuições, conferindo ao Banco do Brasil livre acesso a recursos por meio da conta movimento, e exigindo do BCB um papel de banco de fomento do desenvolvimento, resultou numa expansão da capacidade de investimento do governo brasileiro, especialmente no período conhecido como "milagre brasileiro". Valendo-se desses recursos, gerados mediante a pura e simples emissão de moeda, pretendia-se alçar o BCB a fonte de financiamento público e, mediatamente, a agente de financiamento do desenvolvimento.

O fim dessa história é bem conhecido: a expansão descontrolada da base monetária deu lugar a um processo de inflação intensa (hiperinflação) que tornou o déficit público insustentável e minou a capacidade da moeda de servir como padrão e reserva de valor, dificultando de modo massacrante o desenvolvimento produtivo do país. Além disso, o caráter regressivo do chamado "imposto" inflacionário fez com que os setores mais pobres contribuíssem para o financiamento do déficit público de modo desproporcional, incrementando as desigualdades de renda:

"Como se vê, a ampla utilização do BACEN como fonte de financiamento público, sempre sob o comando direto e incisivo do Poder Executivo, e a promiscuidade entre essa instituição e o Banco do Brasil contribuíram, em muito, para a desorganização completa da ordem monetária nacional. A moeda, durante grande parte da segunda metade do Século XX, foi utilizada

${ }^{173}$ Pedro Malan, Verbete: Superintendência da Moeda e do Crédito (SUMOC). 
no Brasil como um instrumento de política pública, uma fonte inesgotável de recursos à disposição do Poder Executivo, sobre a qual o Poder Legislativo não tinha capacidade alguma de fiscalização. (...) O arranjo institucional que viabilizou esse estado de coisas permaneceu intocável até meados da década de 1980. Com a redemocratização brasileira, a inflação passou a ser um problema cuja solução se tornava inadiável." ${ }^{174}$

Desde a crise inflacionária nos anos 1980, as autoridades monetárias brasileiras têm destinado esforços e concentrado suas ações no sentido de conter a inflação. Como debatido abaixo, a política monetária no país tem sido marcada desde então por notável rigidez e priorização da estabilidade de preços em detrimento de outros objetivos.

\subsection{Autoridade monetária: a quem cabe e quais as atribuições?}

Desde sua criação em 1964, o BCB compartilhava as funções de autoridade monetária não só com o Banco do Brasil, mas também com o Conselho Monetário Nacional (CMN). Com a extinção da conta movimento em 1985, o Banco do Brasil perdeu suas prerrogativas de influenciar diretamente a política monetária (ainda que possa mediatamente fazê-lo, já que é um dos maiores bancos comerciais atuando no país). Assim, a política monetária permaneceu, segundo o modelo da Lei 4.595/64, sob a direção do CMN e execução pelo BCB.

O exame desse dispositivo evidencia que ao $\mathrm{CMN}$ foi atribuído um papel normativo, essencialmente voltado à elaboração da regulação monetária: disciplina da política monetária e de crédito e também da regulação e fiscalização das instituições financeiras. Por sua vez, o BCB foi concebido como um órgão para execução dessas diretrizes.

$\mathrm{O}$ art. 2, ao criar o CMN em substituição à SUMOC, aponta como sua finalidade "formular a política da moeda e do crédito como previsto nesta lei, objetivando o progresso econômico e social do País”, enquanto o art. 3 delimita os objetivos desta política.

\footnotetext{
174 Tiago Machado Cortez, Moeda, estado e direito: o papel do estado na ordem monetária e seu controle, Tese de Doutorado apresentada à Faculdade de Direito da Universidade de São Paulo, p. 183.
} 
Imperioso notar desde já que os objetivos estabelecidos pela Lei ao CMN compreendem a estabilidade monetária e a higidez financeira, mas não se resumem a elas. A preocupação com a relação entre sistema bancário e desenvolvimento é evidente, exigindo assim o ajuste fino entre controle da base monetária e processo de desenvolvimento. Além disso, há expresso reconhecimento do papel do sistema bancário no desenvolvimento regional, e da necessidade de que a autoridade monetária observe e intervenha sobre o fluxo monetário para que não sejam perpetuadas as disparidades.

Os objetivos traçados devem ser buscados pelo CMN em sua atividade de elaboração das diretrizes de atuação do BCB e das instituições financeiras que compõem o sistema financeiro nacional. Essas diretrizes devem compreender três eixos principais:

(i) Formulação da política monetária, compreendendo (a) a aprovação dos orçamentos monetários preparados pelo Banco Central da República do Brasil, (b) definição dos patamares de recolhimento compulsório; (c) definição das condições para operações de redesconto; e (d) disciplina do crédito financeiro.

(ii) Formulação da política cambial.

(iii) Regulação da constituição, funcionamento e fiscalização das instituições financeiras e disciplina do crédito financeiro.

Inicialmente, o CMN era composto por membros do governo e representantes da sociedade civil. Esse conselho sem personalidade jurídica teve sua composição alterada pela Lei 9.069/95 para que passasse a ser formado apenas pelo Presidente do BCB, Ministro do Planejamento e Ministro da Fazenda, como seu presidente.

Por sua vez, o BCB é uma autarquia federal com personalidade jurídica e patrimônio distinto, administrado por uma diretoria composta por quatro membros e um Presidente. A atuação do BCB deve ser essencialmente executiva: pautado pelas diretrizes do CMN, deve lançar mão dos instrumentos de política monetária, cambial e de regulação e fiscalização das instituições financeira para a consecução dos objetivos indicados acima como integrantes das políticas monetária e de crédito. 
O art. 9 da Lei 4.594/64 dispõe expressamente que "Compete ao Banco Central da República do Brasil cumprir e fazer cumprir as disposições que lhe são atribuídas pela legislação em vigor e as normas expedidas pelo Conselho Monetário Nacional". Nesse contexto, compete privativamente ao BCB: (i) emitir moeda; (ii) realizar operações no mercado aberto com títulos públicos federais; (iii) determinar o recolhimento de depósitos compulsórios e os receber; (iv) realizar operações de assistência de liquidez (como o redesconto); (v) exercer o controle do crédito e a fiscalização das instituições bancárias; (vi) fiscalizar o capital estrangeiro.

Duas importantes alterações no ordenamento jurídico reverberaram sobre as autoridades monetárias. A primeira delas foi a promulgação da Constituição Federal de 1988, que trouxe novos fundamentos para a ordem jurídica nacional. A segunda foi a promulgação da Lei 9.069/95, que instituiu um novo regime monetário no país.

Com a promulgação da Constituição Federal de 1988, foi expressamente estabelecida como de competência da União "emitir moeda", "administrar as reservas cambiais do País e fiscalizar as operações de natureza financeira, especialmente as de crédito, câmbio e capitalização, bem como as de seguros e de previdência privada" e legislar sobre "sistema monetário e de medidas, títulos e garantias dos metais" e "política de crédito, câmbio, seguros e transferência de valores" (arts. 20, VII e VIII, e 21, VI e VII, respectivamente). Dessa forma, excluiu-se qualquer possibilidade de emissão de moedas por estados ou influência dos Estados da federação na formulação da política monetária e na regulação financeira, evitando assim possíveis contradições entre ações da União e dos Estados nessa área ${ }^{175}$.

\footnotetext{
${ }^{175}$ A regulação monetária deixou pouco espaço para os entes federados. Estados e municípios não participam diretamente da formulação da política monetária e mecanismos como títulos públicos estaduais e bancos estaduais foram limitados pelas reformas da década de 1990, conforme detalhado na nota 204 abaixo. Dessa forma, a noção de Federalismo quanto à regulação monetária tem se enfraquecido à luz da concentração de Poderes pela União. Uma análise lúcida e com muitas referências importantes acerca do Federalismo no Brasil pode ser encontrada em Gilberto Bercovici, Desigualdades regionais, estado e constituição, op. cit., pp. 145 e ss. Destaque-se ainda que na nota 206 há referência importante sobre o reflexo da política monetária contracionista sobre o orçamento fiscal, o que também tem reflexos sobre o pacto federativo. Por fim vale notar a observação de Luis Fernando Schuartz no sentido de que a exigência de aprovação pelo Senado - "instituição que encarna os valores federativos" - para nomeação dos dirigentes do BCB procura conciliar a igualdade do Estados na gestão monetária (Banco Central: questões jurídico-políticas na Constituição de 1988, in Revista de Direito Mercanti, Industrial, Econômico e Financeiro 93 (1994), pp. 3637.
} 
Além disso, o art. 48 atribui ao Congresso Nacional a competência para "dispor sobre todas as matérias de competência da União, especialmente sobre: (...) XIII - matéria financeira, cambial e monetária, instituições financeiras e suas operações; XIV - moeda, seus limites de emissão, e montante da dívida mobiliária federal". Interessante notar que o Poder Legislativo instituído enquanto poder constituinte originário tinha nítido interesse em manter consigo os poderes sobre a gestão da moeda, do crédito e da disciplina das instituições financeiras o que, no entanto, não se refletiu em um papel ativo do Congresso Nacional nessa área, como se verá à frente.

Como resultado desse interesse inicial dos constituintes originários, o Congresso Nacional tem, segundo a Constituição Federal, papel central na disciplina da política monetária e de crédito e na regulação das atividades das instituições financeiras. A esse ente foi atribuída pela norma de máxima envergadura no sistema brasileiro a competência para definição dessas matérias, tendo em vista, evidentemente, a necessidade de atenção aos princípios constitucionais que devem informar a atuação do Estado em geral e aqueles dedicados especificamente à disciplina sistema financeiro (conforme, por exemplo, as disciplinas dos arts. 3 e 192, a seguir debatidas).

A centralidade conferida pela Constituição Federal ao Poder Legislativo é confirmada por sua participação necessária no processo de nomeação dos dirigentes do $\mathrm{BCB}^{176}$. $\mathrm{O}$ art. 52, III, d, exige que os membros da diretoria do $\mathrm{BCB}$ sejam indicados pelo Presidente da República e submetidos à sabatina perante o Senado, que deve aprovar ou não a indicação.

A Lei 4.595/65 foi considerada como recepcionada pela Constituição Federal de 1988 como lei complementar, inclusive com a delegação de funções do Congresso Nacional ao CMN. No entanto, as delegações de funções do Congresso Nacional ao Poder Executivo anteriores à nova Constituição haviam sido revogadas pelo art. 25 do Ato das

\footnotetext{
${ }^{176}$ Cumpre observar que a Constituição se refere ao banco central, que pode ser o BCB, conforme constituído pela Lei 4.595/64 ou a outra instituição que venha a ser instituída em seu lugar.
} 
Disposições Constitucionais Transitórias (ADCT). Foi conferido o prazo de 180 dias da promulgação da Constituição para que essa revogação se tornasse eficaz ${ }^{177}$.

Medidas provisórias e leis se seguiram com o objetivo de estender a delegação conferida ao CMN e assegurar sua capacidade normativa ${ }^{178}$. Finalmente, a Lei 8.392/91 prorrogou a vigência dos dispositivos que atribuíram capacidade normativa ao CMN "até a data da promulgação da lei complementar de que trata o art. 192 da Constituição Federal" (portanto, lei ordinária prorrogou a delegação instituída por lei recepcionada como complementar). Essa lei complementar, no entanto, permanece sem ser promulgada, resultando na permanência da vigência da delegação atribuída pela Lei 4.595/64 ao CMN para disciplina da política monetária e de crédito.

Por sua vez, a Lei 9.069/95, que instituiu um novo regime monetário e o Real como a unidade do sistema, reconheceu expressamente o CMN e o BCB como as autoridades monetárias do país (a despeito de utilizar impropriamente a expressão no singular). Essa lei atribuiu ao BCB a competência para elaboração da programação monetária para cada trimestre, devendo submetê-la ao CMN para aprovação (art. 6). A programação monetária compreende "I - estimativas das faixas de variação dos principais agregados monetários compatíveis com o objetivo de assegurar a estabilidade da moeda; e II - análise da evolução da economia nacional prevista para o trimestre, e justificativa da programação monetária." Após aprovação do $\mathrm{CMN}$, a programação monetária deve ser encaminhada à Comissão de Assuntos Econômicos do Senado Federal para que o Congresso Nacional, com base em parecer dessa Comissão, possa avaliar a programação monetária (caso não seja avaliada no prazo previsto, a aprovação se dá automaticamente).

Portanto, a Lei 9.069/95 alterou a dinâmica da Lei 4.595/64 e conferiu ao BCB a possibilidade de influenciar a elaboração da política monetária, relegando ao CMN a competência para aprovação da programação monetária elaborada pelo BCB. Nesse sentido, o BCB criou, por meio de uma Circular, o Comitê de Política Monetária

\footnotetext{
177 “Art. 25. Ficam revogados, a partir de cento e oitenta dias da promulgação da Constituição, sujeito este prazo a prorrogação por lei, todos os dispositivos legais que atribuam ou deleguem a órgão do Poder Executivo competência assinalada pela Constituição ao Congresso Nacional, especialmente no que tange a: I - ação normativa;"

${ }^{178}$ Medidas Provisórias n. 45, 53 e 188, e Leis 7.770/89, 7.892/89, 8.056/90, 8.127/90 e 8.201/91.
} 
(COPOM), em junho de 1996, composto unicamente por membros do BCB e com o objetivo de estabelecer as diretrizes da política monetária e fixar a taxa de juros básica.

\subsection{Constituição, desenvolvimento regional e autoridade monetária}

Esse trabalho parte de um problema fático facilmente identificável na realidade nacional: a desigualdade entre os cidadãos e regiões do Brasil em diversas dimensões renda, escolaridade, nível de produtividade.

Esse problema não constitui apenas uma questão de justiça social. Ao contrário, ele influencia negativamente o desenvolvimento econômico do país como um todo, já que sociedades menos desiguais apresentam trajetórias de desenvolvimento mais sustentáveis em comparação com sociedades mais desiguais, como já apontado no capítulo 1. Além disso, a disparidade regional é também um problema jurídico, sendo claramente elencada no texto constitucional como uma situação a ser revertida pela sociedade brasileira. A partir principalmente da Constituição de 1946, todas as Constituições brasileiras procuram trazer disposições para a superação das desigualdades regionais, e a de 1988 reflete nitidamente essa preocupação em seu art. $3^{\circ}$.

Portanto, mesmo os mais pragmáticos e que rejeitam de plano uma discussão filosófica sobre os conceitos de igualdade ou a necessidade de sua concretização, não podem fugir da necessidade de se analisar as causas e propor ações claras no sentido de minimizar e reverter o desenvolvimento regional desigual. Dentro do pragmatismo que pretende orientar este trabalho, o desenvolvimento regional compreende uma questão de eficiência econômica (o país é menos eficiente e tem menor potencial de desenvolvimento em razão da desigualdade) e foi objeto de nítido tratamento jurídico, sendo alçado a objetivo da República.

A emergência do problema regional como uma questão constitucional se dá num contexto de crença no Direito como um fator de mudança da realidade: o substrato jurídico daria força e legitimaria a mudança social. Esse contexto advém dos debates sobre o 
“constitucionalismo social" do século XX, sendo marcado pela ideia de Constituição Econômica $^{179}$.

Ainda que as constituições liberais dos séculos XVIII e XIX possuíssem disposições econômicas, o que veio ser denominado de Constituição Econômica se diferencia do paradigma das constituições liberais porque não pretende apenas dar conformação jurídica à estrutura econômica pré-existente, mas almeja alterar essa estrutura, positivando tarefas e objetivos a serem realizados pelo Estado e pelos particulares. Portanto, a Constituição Econômica não se satisfaz com a livre regulação do mercado e disposições que garantam os direitos de propriedade e a livre iniciativa. De fato, compreendendo que estruturas desiguais exigem ações diretas no sentido de sua reversão, a Constituição Econômica busca a configuração jurídica de diversos elementos do plano econômico e social. Daí falar-se em Constituição Dirigente ${ }^{180}$.

A concepção de uma Constituição Dirigente assume que o direito pode ter um papel relevante na realização de mudanças sobre a realidade social e procura vincular a ação política, tanto no âmbito legislativo quanto executivo, às disposições trazidas pelo texto constitucional. A atenção e aplicação do que disposto no plano constitucional é alçada a elemento capaz de materialmente legitimar a ação política.

$\mathrm{O}$ art. $3^{\circ}$ da Constituição Federal aponta como objetivos da República: "I - construir uma sociedade livre, justa e solidária; II - garantir o desenvolvimento nacional; III erradicar a pobreza e a marginalização e reduzir as desigualdades sociais e regionais; IV promover o bem de todos, sem preconceitos de origem, raça, sexo, cor, idade e quaisquer outras formas de discriminação".

\footnotetext{
${ }^{179} \mathrm{O}$ conceito de constituição econômica e suas diversas acepções são debatidos e sintetizados por Vital Moreira, Economia e Constituição - para o conceito de Constituição Econômica, Separata do Boletim de Ciências Econômicas XVII (1974), pp. 15 e ss.

${ }^{180}$ A respeito ver José Joaquim Gomes Canotilho, Constituição Dirigente e vinculação do legislador: contributo para a compreensão das normas constitucionais programáticas, 2. ed., Coimbra, 2001, p. 224, e Gilberto Bercovici, Constituição econômica e desenvolvimento - uma leitura a partir da Constituição de 1988, op. cit., pp. 31 e ss.
} 
Esse dispositivo evidencia que "a Constituição de 1988 é, claramente, uma Constituição Dirigente"181. Como resultado, impõe-se uma "interpretação dinâmica", voltada à transformação da sociedade por meio de políticas públicas destinadas à concretização dos fins constitucionalmente estabelecidos:

\begin{abstract}
"Constituição dirigente que é, a de 1988 reclama - e não apenas autoriza - interpretação dinâmica. Volta-se à transformação da sociedade, transformação que será promovida na medida em que se reconheça, no art. $3^{\circ}$ - e isso se impõe -, fundamento à reivindicação, pela sociedade, de direito à realização de política públicas. Políticas públicas que, objeto de reivindicação constitucionalmente legitimada, hão de importar o fornecimento de prestações positivas à sociedade." ${ }^{, 182}$
\end{abstract}

Assim, a Constituição Federal estabelece, por meio do art. 3º "princípios constitucionais fundamentais" $" 183$, que podem ser considerados princípios constitucionais impositivos, na dicção de Canotilho ${ }^{184}$, ou norma-objetivo, conforme caracterização de Eros Grau ${ }^{185}$, que impõe ao Estado o dever de promover o desenvolvimento regional, alçando esse aspecto a um dos elementos que deve integrar a concepção de desenvolvimento econômico a ser promovida pelo Estado brasileiro, orientando assim os parâmetros das ferramentas a serem utilizadas nas políticas econômicas do governo ${ }^{186}$.

Importante ainda destacar que não se pode questionar a eficácia e aplicabilidade desses princípios. No Brasil, ao menos desde a publicação da obra de José Afonso da Silva sobre a aplicabilidade das normas constitucionais, que é talvez a doutrina mais aceita e replicada no país nesse campo ${ }^{187}$, tem-se cada vez mais assentado o entendimento de que normas desse tipo têm sim eficácia desde sua promulgação ${ }^{188}$. Considerando a tríplice classificação do mencionado autor acerca das normas constitucionais - normas de eficácia

${ }^{181}$ Gilberto Bercovici, Constituição econômica e desenvolvimento - uma leitura a partir da Constituição de 1988, op. cit., p. 36.

${ }^{182}$ Eros Grau, A ordem econômica na Constituição de 1988, p. 200.

${ }^{183}$ Gilberto Bercovici, Desigualdades regionais, estado e constituição, op. cit., p. 291

${ }^{184}$ Direito Constitucional, 3. ed., Coimbra: Almedina, p. 200.

${ }^{185}$ A ordem econômica na Constituição de 1988, pp. 200-4

${ }^{186}$ Ibidem, p. 203.

187 Virgílio Afonso da Silva, Direitos Fundamentais - conteúdo essencial, restrições e eficácia, 2. ed., São Paulo: Malheiros, 2010, p. 209.

188 José Afonso da Silva, Aplicabilidade das normas constitucionais, 8. ed., São Paulo: Malheiros, 2012, p. 136. 
plena, normas de eficácia contida e normas de eficácia limitada -, acredito que o art. $3^{\circ}$ se enquadra como norma de eficácia limitada de princípio programático.

As normas incluídas pelo autor dentro dessa categoria traçam as diretrizes a serem seguidas pelo Estado e - como se verá à frente, também pelos particulares - para o alcance dos objetivos nelas definidos ${ }^{189}$. Dessa forma, elas impõem limites ou exigem comportamentos desde sua promulgação, gerando efeitos (sendo eficaz), mas exigem comportamentos, programas de ação (executiva ou legislativa) ou outras normas para que sejam totalmente eficazes num sentido estritamente jurídico. Deve-se enfatizar que José Afonso da Silva não está nem mesmo se referindo à efetividade no sentido de "realização do Direito, o desempenho concreto de sua função social"190, mas sim a uma eficácia estritamente jurídica, que dependeria de outras variáveis além do texto constitucional para ser plena.

A crítica de Virgílio Afonso da Silva a essa teoria tem elementos relevantes para o presente trabalho. Analisando a classificação tríplice de José Afonso da Silva especificamente quanto aos direitos fundamentais, preconiza que a distinção proposta entre normas de eficácia plena, contida e limitada não subsiste porque todas as normas constitucionais relativas a direitos fundamentais exigem, em algo grau, regulamentação e atuação do Estado para sua eficácia e efetividade, podendo, dessa forma, ser restritas. Nesse sentido, "a limitação da eficácia de determinadas normas não é algo intrínseco a elas. Uma norma não é de eficácia limitada por uma questão meramente textual ou "estritamente jurídica"”. Para esse autor, "essa limitação depende muito mais de opções político-ideológicas que não têm necessária relação com o texto constitucional. Toda norma, a partir desse ponto de vista, tem eficácia limitada - mas algumas delas, por razões extrínsecas, têm melhores condições de produzir efeitos" ${ }^{\prime 191}$.

\footnotetext{
189 "Podemos conceber como programáticas aquelas normas constitucionais através das quais o constituinte, em vez de regular, direta e imediatamente, determinados interesses, limitou-se a traçar-lhes os princípios para serem cumpridos pelos seus órgãos (legislativos, executivos, jurisdicionais $e$ administrativos), como programas das respectivas atividades, visando à realização dos fins sociais do estado." (José Afonso da Silva, Aplicabilidade das normas constitucionais, op. cit., p. 135)

${ }^{190}$ Luís Roberto Barroso, O direito constitucional e a efetividade de suas normas, 4 ed., Rio de Janeiro: Renovar, 2000, p. 85.

${ }^{191}$ Direitos Fundamentais - conteúdo essencial, restrições e eficácia, op. cit., p. 232.
} 
Virgílio Afonso da Silva utiliza dois exemplos para demonstrar seu argumento, contrapondo direitos políticos (como o sufrágio universal) e liberdades públicas (como o direito de propriedade), usualmente indicados como de eficácia plena, com direitos sociais como o direito à saúde.

Essas duas categorias de direitos são usualmente separadas por um critério pautado na atuação estatal: as liberdades individuais são direitos negativos, pois exigem uma abstenção, enquanto os direitos sociais, de outro lado, dependeriam de custosas ações estatais para sua efetivação. Entretanto, essa dicotomia não resiste a um exame mais criterioso da questão. Os direitos sociais, para sua observação, efetivamente exigem dispêndios públicos que serão utilizados em ações estatais organizadas para esse fim. No entanto, o mesmo é verdadeiro no que diz respeito aos direitos negativos ou abstencionistas. A garantia das liberdades individuais exige atuação e dispêndios do Estado no sentido de constituir e manter instituições capazes de efetivar tais direitos. Exemplos evidentes dessa assertiva são encontrados na manutenção de um Poder Judiciário independente (capaz de assegurar, por exemplo, os direitos de propriedade), de um poder Legislativo e na realização de eleições.

Em outras palavras, os direitos de primeira geração também dependem de prestações e dispêndios estatais, que se equiparam àqueles exigidos para a efetivação dos direitos sociais, sendo também direitos positivos: "Rights are costly because remedies are costly. Enforcement is expensive, especially uniform and fair enforcement; and legal rights are hollow to the extent that they remain unenforced." 192

Dessa forma, não existiriam normas de eficácia plena num sentido estritamente jurídico, já que todas necessitam de ação estatal e não mera abstenção. A diferença entre as normas, segundo Virgílio Afonso da Silva, residiria apenas nas condições fáticas iniciais. No caso das liberdades públicas e direitos políticos, muitas das condições fáticas, institucionais e legais para uma produção quase plena dos efeitos já existem, enquanto que as condições para o exercício de direitos sociais ainda dependem de uma série de ações e políticas públicas.

${ }^{192}$ Stephen Holmes e Cass R. Sustein, The Cost of Rights - Why Liberty Depends on Taxes, New York: W. W. Norton, p. 43. 
Nesse sentido, o autor identifica, com muita lucidez, que a efetividade dos direitos sociais é mais baixa, pois exigem, além das instituições em geral necessárias e já existentes para efetivação de direitos políticos e liberdade públicas, recursos financeiros específicos e de alto vulto, terminando por impor escolhas aos legisladores, administradores e juízes. Como resultado, e considerando ainda que todos os direitos fundamentais necessitam de regulamentação (e, portanto, são passíveis de restrição), o autor conclui pela necessidade de imposição de um maior ônus argumentativo ao legislador, administrador ou juiz. Qualquer escolha (seja no sentido de ação ou omissão), como implica em alguma modalidade de restrição, deve ser fundamentada ${ }^{193}$.

Essa conclusão é muito relevante para os fins deste trabalho. Isso porque o art. $3^{\circ} \mathrm{da}$ Constituição Federal prevê um verdadeiro programa de ação para os Poderes Legislativo e Executivo, exigindo uma série de ações e políticas coordenadas, sendo verdadeira cláusula transformadora, como explica Gilberto Bercovici:

\begin{abstract}
"O artigo $3^{\circ}$ da Constituição de 1988, além de integrar a fórmula política, também é, na expressão de Pablo Lucas Verdú, a 'cláusula transformadora' da Constituição. A ideia de 'cláusula transformadora' está ligada ao artigo $3^{\circ}$ da Constituição italiana de 1947 e ao artigo $9^{\circ}$ da Constituição espanhola de 1978. Em ambos os casos, a "cláusula transformadora' explicita o contraste entre a realidade social injusta e a necessidade de eliminá-la. Deste modo, impedem que a Constituição considerasse realizado o que ainda está por se realizar, implicando na orbigação do Estado em promover a transformação da estrutura econômico-social. (...) A eficácia jurídica desses artigos, assim como a do nosso artigo $3^{\circ}$, não é incompatível com o fato de que, por seu conteúdo, a realização destes preceitos tenha caráter progressivo e dinâmico e, de certo modo, sempre inacabado. Sua concretização não significa a imediata exigência de prestação estatal concreta, mas uma atitude positiva, constante e diligente do Estado."194
\end{abstract}

De fato, o artigo $3^{\circ}$ se diferencia dos demais pelo volume de atividade e conjunto de elementos e escolhas necessárias. O desenvolvimento do país e a redução das desigualdades exige uma série de políticas e regulamentações coordenadas, capazes de aliar ação estatal e regulamentação e indução da ação dos particulares para que, no agregado, resultem em evolução das condições atuais. Assim, se de um lado é evidente que esse artigo é eficaz desde a promulgação da Constituição de 1988, ele é possivelmente a

${ }^{193}$ Virgílio Afonso da Silva, Direitos Fundamentais - conteúdo essencial, restrições e eficácia, op. cit., p. 250-1.

${ }^{194}$ Desigualdades regionais, estado e constituição, op.cit., p. 294. 
norma constitucional que exige maior nível de regulamentação e ação do Estado para sua efetividade. Considerando que o desenvolvimento da sociedade e redução das desigualdades são processos em constante evolução e, possivelmente, intermináveis, a eficácia desses dispositivos se identifica com uma postura ativa dos órgãos estatais e dos particulares no sentido de contribuir para esse processo em todas as esferas e atividades.

Nesse processo, no entanto, serão necessárias, muitas vezes, limitações ou escolhas sobre determinadas ações ou concretizações de determinados direitos. Nesse sentido, por exemplo, optar por maiores investimentos em saúde pode significar menos investimento em tecnologia ou ações no sentido de incrementar o acesso à cultura podem limitar, ao menos no médio prazo, incentivos à construção de infra-estrutura. Esses exemplos quase caricaturais visam apenas demonstrar que a concretização do processo de desenvolvimento envolverá uma série de escolhas, com preferência e preteridos. Importa, nesse ponto, que todas essas escolhas sejam pautadas por adequada fundamentação o que compreende não apenas a demonstração de sua adequação e necessidade em vista do próprio fim mas, especialmente, sua inserção no contexto da política de desenvolvimento. A importância da responsabilização (accountability) dos entes públicos investidos de capacidade de realizar essas escolhas emerge como fundamental.

Em razão da abertura das possibilidades interpretativas e das diversas escolhas possíveis, a própria Constituição Federal já prevê uma série de normas que contribuem para a definição dos vetores que deverão confluir para o desenvolvimento do país e alcance dos objetivos traçados no art. $3^{\circ}$. Nesse sentido, a concretização dos direitos fundamentais na maior extensão possível é uma das etapas desse processo, conforme previsão doa artigos 5,6 e 7 . Outro aspecto muito relevante diz respeito à organização da ordem econômica.

Desnecessário dizer que a organização dos sistemas produtivo e monetário é essencial no processo de desenvolvimento. E isso foi nitidamente reconhecido pela Constituição de 1988, verdadeira Constituição Econômica, uma vez que não pretende apenas dar conformação jurídica à estrutura econômica pré-existente (como nas 
constituições tipicamente liberais), mas almeja alterar essa estrutura, positivando tarefas e objetivos a serem realizados pelo Estado e pelos particulares ${ }^{195}$.

Dessa forma, ao prever diversos objetivos fundamentais para a República brasileira, a própria Constituição já delineou alguns elementos e vetores que deverão constituir os pilares de sua ação na esfera econômica. Nesse contexto, o artigo 170 não apenas corrobora a percepção de que a ordem econômica deve ter papel central no processo de concretização dos objetivos do artigo $3^{\circ}$, estabelecendo como fim da ordem econômica o desenvolvimento econômico e a redução da desigualdade (expressos por meios da fórmula "existência digna, conforme os ditames da justiça social"), mas também estabelece os vetores da ação estatal com vistas à concretização desses objetivos.

Possível depreender então que, nesse ponto, a Constituição disciplina a ordem econômica enquanto conceito de fato, que exprime a realidade da articulação do fenômeno econômico enquanto estrutura. A Constituição traz vetores e limites que devem fundamentar essa articulação ("existência digna, conforme os ditames da justiça social”), bem como os princípios a ela relacionados, que visam constranger os comportamentos dos agentes econômicos.

Além disso, o artigo 170 disciplina também a ordem econômica como regime da ordem jurídica da economia, apresentando os fundamentos e diretrizes jurídicas para a formação do conjunto de regras jurídicas que regulamentam a vida econômica ${ }^{196}$. Esse artigo contém os princípios que devem estruturar o que Fabio Konder Comparato

\footnotetext{
${ }^{195}$ Uma análise do contexto social dessa evolução pode ser vista em Vital Moreira, A ordem jurídica do capitalismo, Coimbra: Centelho, 1978, pp. 81 e ss.

${ }^{196}$ Essa distinção entre ordem econômica de fato e jurídica é baseada em Vital Moreira, que distingue ainda um terceiro tipo que é a ordem não apenas jurídica mas normativa, incluindo normas jurídicas religiosas e morais que atuam na regulamentação do comportamento dos agentes econômicos (A ordem jurídica do capitalismo, op. cit, pp. 67-71). È importante notar que, em sentido contrário ao exposto no texto, o Professor Eros Grau aponta a disciplina da Constituição como pertinente unicamente ao conceito jurídico da ordem econômica, sendo o "conjunto de normas que institucionaliza determinada ordem econômica" (A ordem econômica na Constituição de 1988, op. cit., p. 63). Insisto em afirmar que disciplina da ordem econômica na Constituição se refere tanto à ordem fática quanto à ordem jurídica porque acredito que a disciplina da Constituição irradia efeitos diretamente sobre a ordem fática. Portanto, ainda que não houvesse outros regulamentos, a ordem fática já deve integrar a disciplina trazida pela Constituição, que passa a fazer parte da própria estrutura fática.
} 
denominou de "conjunto das técnicas jurídicas de que lança mão o Estado contemporâneo na realização de sua política econômica.",197

Esses princípios são: "I - soberania nacional; II - propriedade privada; III - função social da propriedade; IV - livre concorrência; V - defesa do consumidor; VI - defesa do meio ambiente, inclusive mediante tratamento diferenciado conforme o impacto ambiental dos produtos e serviços e de seus processos de elaboração e prestação; VII - redução das desigualdades regionais e sociais; e VIII - busca do pleno emprego; IX - tratamento favorecido para as empresas de pequeno porte constituídas sob as leis brasileiras e que tenham sua sede e administração no País."

O exame dos princípios elencados pelo artigo 170 evidencia que a ordem econômica no Brasil (no mundo do ser e do dever-ser) deve ter como base a iniciativa privada e a livre concorrência, devendo ser a atuação direta do Estado mais pontual do que extensa ou em substituição ao setor privado. No entanto, esse dispositivo também deixa claro que a atuação de agentes econômicos privados terá como fundamento o interesse do Estado, sendo voltada à realização dos fundamentos da República. Nesse sentido, princípios como o da soberania nacional, função social da propriedade, redução das desigualdades regionais e sociais e busca do pleno emprego evidenciam que a lógica da acumulação privada deverá prevalecer somente enquanto for capaz de se manter alinhada a esses princípios. Quando a lógica privada se desviar desses objetivos e, consequentemente, deixar de encontrar fundamento na busca por "existência digna, conforme os ditames da justiça social", a atuação do Estado, necessariamente consubstanciada por Lei proferida pelo Congresso Nacional, será legítima para regulamentar a atividade dos particulares e procurar constranger os comportamentos no sentido de realização desses objetivos.

Para os fins específicos deste trabalho, é relevante enfatizar que o artigo 170 reforça a noção de que o Estado e também os particulares deverão atuar no sentido de concretizar o desenvolvimento do país e aponta, em linha com o artigo $3^{\circ}$, que a redução das desigualdades regionais é elemento fundamental no processo de desenvolvimento, devendo ser um dos elementos que norteiam a atuação do Estado sobre a ordem econômica (art. 170, VII).

${ }^{197}$ O indispensável Direito Econômico, in Ensaios e Pareceres de Direito Empresarial, Rio de Janeiro: Forense, 1978, p. 465. 
A despeito de certa controvérsia sobre a aplicabilidade dos artigos 170 e seguintes ao Sistema Financeiro Nacional, acredito que as disposições sobre a ordem econômica devem sim ser aplicadas aos agentes financeiros. Não vislumbro qualquer fundamento na dogmática jurídica para que se conclua que ao sistema financeiro se aplica unicamente o artigo 192, a ele especificamente destinado. Com efeito, as disposições do Capítulo 1 ("Dos Princípios Gerais da Atividade Econômica") do Título VII da Constituição ("Da Ordem Econômica e Financeira") são aplicáveis a toda e qualquer atividade econômica, inclusive as atividades financeiras. O fato de haver um Capítulo especificamente destinado a essas atividades não exclui as disposições de caráter geral do Capítulo 1, o que é confirmado pelo fato de não haver qualquer incongruência entre elas.

O Capítulo IV, que disciplina exclusivamente o Sistema Financeiro, é composto pelo artigo 192, que, após a Emenda Constitucional n 40, passou a ter a seguinte redação:

"Art. 192. O sistema financeiro nacional, estruturado de forma a promover o desenvolvimento equilibrado do País e a servir aos interesses da coletividade, em todas as partes que o compõem, abrangendo as cooperativas de crédito, será regulado por leis complementares que disporão, inclusive, sobre a participação do capital estrangeiro nas instituições que o integram."

Depreende-se desse artigo que, em linha com as disposições gerais sobre a ordem econômica, a estrutura do sistema financeiro de fato e também seu regramento jurídico devem ter como objeto "promover o desenvolvimento equilibrado do País" e "servir aos interesses da coletividade". Nesse ponto, é evidente que a norma não se limita a descrever a estrutura, afirmando que a estrutura do sistema financeiro já vigente deve ser alterada na busca desses objetivos. Na verdade, a única interpretação logicamente possível é que ela estabelece um dever-ser, uma prescrição para alterações na estrutura do sistema financeiro.

É interessante notar que o Sistema Financeiro Nacional é o único subsistema econômico com uma disposição constitucional especificamente destinada a reiterar que cabe aos agentes públicos e particulares nele inseridos promover o desenvolvimento do 
país. Mais do que isso, a Constituição se refere expressamente a desenvolvimento equilibrado, ressaltando o papel de destaque do sistema financeiro na promoção do desenvolvimento regional.

Nesse sentido, deve-se ter presente que a disposição do art. $3^{\circ}$ da Constituição Federal no sentido de exigir do Estado e dos particulares ações no sentido de fomentar o desenvolvimento nacional e o desenvolvimento das regiões, promovendo a redução da desigualdade, é complementada por outras disposições constitucionais que não apenas reforçam esse mandamento mas direcionam a ação do Estado.

Como discutido acima, o artigo $3^{\circ}$ é uma norma extremamente complexa por exigir um conjunto coordenado de diversas políticas e regulamentações, num processo contínuo e, possivelmente, interminável - de ação estatal e dos particulares no sentido de sua consecução. Nesse processo, no entanto, serão necessárias, muitas vezes, limitações ou escolhas sobre determinadas ações ou concretizações de determinados direitos, bem como definições de atribuições, deveres e direitos.

Essas escolhas são, certamente, muito difíceis e exigem ampla atividade interpretativa. No entanto, a própria Constituição já deu início à elaboração desse programa de ação, alçando o desenvolvimento regional como um dos princípios da ordem econômica, devendo nortear em certa medida todos os setores da economia e atuação estatal sobre eles. E, ainda mais expressamente e com uma ênfase particular, determinou que a estrutura fática e jurídica do sistema financeiro nacional seja conformada de modo a promover o "desenvolvimento equilibrado do país". Portanto, a Constituição atribuiu ao Sistema Financeiro um papel central e impreterível no contexto da política de desenvolvimento, que compreende, na dicção constitucional, o desenvolvimento equilibrado entre as regiões.

Necessário concluir que as atividades dos agentes privados e públicos que atuam no sistema financeiro devem se sujeitar à exigência constitucional de promoção do desenvolvimento regional equilibrado ${ }^{198}$. A exposição de Gilberto Bercovici sobre o artigo

\footnotetext{
${ }^{198}$ A observação de Washington Peluso Albino de Souza é precisa ao enfatizar que "no Direito Econômico em especial, pelo que tem de particular em compromisso com a regulamentação da política econômica e seu enquadramento dentro do respeito aos interesses sociais e à segurança individual na vida em sociedade, a
} 
$3^{\text {o }}$ certamente compreende o sistema financeiro nacional, inclusive com particular ênfase em função dos artigos 170 e 192:

\begin{abstract}
"Todos os atos do Estado e dos agentes públicos devem estar em conformidade formal e material com a Constituição. Caso não estejam adequados substancialmente ao texto constitucional, ocorre a inconstitucionalidade material, que reflete o desajuste entre o conteúdo dos preceitos constitucionais e o conteúdo das normas hierarquicamente inferiores, que estão vinculadas materialmente ao texto constitucional. $\mathrm{O}$ controle material de constitucionalidade incide sobre o teor e a matéria da norma, para que esta esteja adequada à Constituição e a seus princípios fundamentais, ocorrendo inconstitucionalidade material também com a violação dos fins prescritos no texto constitucional, como os do art. 3 da CF". ${ }^{199}$
\end{abstract}

Quanto aos agentes públicos, foi indicado acima que a Constituição Federal de 1988 estabeleceu como de competência da União as atividades pertinentes à regulamentação e atuação sobre o sistema financeiro nacional (arts. 20, VII e VIII, e 21, VI e VII, respectivamente), atribuindo ao Congresso Nacional a competência para dispor sobre essas matérias (art. 48).

Como resultado, o Congresso Nacional tem, segundo a Constituição Federal, papel central na disciplina da política monetária e de crédito e na regulação das atividades das instituições financeiras. A Lei 4.595/65 foi considerada como recepcionada pela Constituição Federal de 1988, inclusive com a delegação dessas funções do Congresso Nacional ao CMN.

A norma recepcionada, sob a perspectiva aqui debatida, parece encontrar-se efetivamente em linha com a Constituição Federal. Afinal, a Lei 4.595/64, ao criar o CMN e BCB e conferir a essas instituições o papel de autoridade monetária e de regulação do setor financeiro, foi expressa ao alçar o desenvolvimento regional como um dos objetivos da política monetária e de crédito, além de inserir uma série de instrumentos e ferramentas de caráter regional tanto no desempenho dessa política quanto na regulação das instituições financeiras.

Constituição , enquanto lei maior, é a fonte principal de que se dispõe. Esta posição define como o repositório de princípios ideológicos de que se socorre o Direito Econômico para a sua própria efetivação" (Direito Econômico, Saraiva, 1980, p. 139).

${ }^{199}$ Constituição econômica e desenvolvimento - uma leitura a partir da Constituição de 1988, pp. $110-1$. 
A exposição de motivos para a promulgação dessa Lei em 1964 ratifica o caráter transformador pretendido pelo elemento jurídico quanto ao sistema financeiro:

\begin{abstract}
"Promover as modificações no regime jurídico das instituições financeiras privadas de modo que sua atuação contribua para a utilização mais eficiente dos recursos financeiros nacionais, promover distribuição mais equitativa desses recursos, e facilitar o desenvolvimento harmônico das diferentes regiões do país." 200
\end{abstract}

Assim, as autoridades monetárias, responsáveis pelo controle quantitativo e qualitativo da liquidez da economia e também pela regulação das atividades das instituições financeiras, receberam nítido mandato no sentido de contribuir para a promoção do desenvolvimento nacional e, principalmente, fomentar a redução das desigualdades entre regiões. Nesse sentido, o artigo $3^{\circ}$ da Lei $4.595 / 65$ estabelece como objetivos da política da moeda e do crédito a ser elaborada pelo $\mathrm{CMN}$ :

"I - Adaptar o volume dos meios de pagamento às reais necessidades da economia nacional e seu processo de desenvolvimento;

II - Regular o valor interno da moeda, para tanto prevenindo ou corrigindo os surtos inflacionários ou deflacionários de origem interna ou externa, as depressões econômicas e outros desequilíbrios oriundos de fenômenos conjunturais;

III - Regular o valor externo da moeda e o equilíbrio no balanço de pagamento do País, tendo em vista a melhor utilização dos recursos em moeda estrangeira;

IV - Orientar a aplicação dos recursos das instituições financeiras, quer públicas, quer privadas; tendo em vista propiciar, nas diferentes regiões do País, condições favoráveis ao desenvolvimento harmônico da economia nacional;

V - Propiciar o aperfeiçoamento das instituições e dos instrumentos financeiros, com vistas à maior eficiência do sistema de pagamentos e de mobilização de recursos;

VI - Zelar pela liquidez e solvência das instituições financeiras;

VII - Coordenar as políticas monetária, creditícia, orçamentária, fiscal e da dívida pública, interna e externa."

${ }^{200} \mathrm{O}$ texto da exposição de motivos foi extraído de Florinda Figueiredo Borges, Intervenção estatal na economia: o banco central e a execução das políticas monetária e creditícia, Dissertação de mestrado, Faculdade de Direito da Universidade de São Paulo, 2010, p. 184. 
O exame desses dispositivos permite concluir que a regulação monetária, em linha com a ortodoxia econômica exposta acima, deverá preservar a estabilidade monetária e evitar processos inflacionários. No entanto, a estabilidade de preços e higidez financeira não constitui fim em si mesmo, sendo apenas um dos elementos a serem ponderados na regulação monetária, que deverá ser conformada para atender a necessidade de desenvolvimento da economia.

É o que se depreende da leitura dos incisos I e II, particularmente voltados ao controle quantitativo da base monetária. Além do ajuste quantitativo que, reitere-se deve sopesar o imperativo de estabilidade de preço com as necessidades de capital da economia para que o processo de desenvolvimento de perpetue e se intensifique, a Lei estabelece controles qualitativos dos recursos financeiros. Assim, a regulação das instituições financeiras deve objetivar não apenas a garantia da higidez dessas instituições (inciso VI), mas também promover a eficiência do sistema de pagamentos e mobilização de recursos (inciso V) e influenciar a aplicação dos recursos das instituições financeiras "tendo em vista propiciar, nas diferentes regiões do País, condições favoráveis ao desenvolvimento harmônico da economia nacional" (inciso IV).

Portanto, diante do problema econômico identificado no capítulo anterior, em que a livre atuação dos agentes privados leva à concentração de crédito nas regiões mais desenvolvidas, resultando assim na escassez de crédito nas regiões menos desenvolvidas, a Lei 4.595/64 fixou como objetivo expresso da política monetária e de crédito o estabelecimento de controles qualitativos do crédito financeiro, para que recursos sejam distribuídos entre as diferentes regiões de modo a propiciar o desenvolvimento harmônico entre elas.

Nesse sentido, como destacado acima, o artigo $4^{\circ}$ dessa Lei ao dispor sobre as competências normativas do CMN atribuiu poderes para formulação da política monetária e de crédito, compreendendo (i) a aprovação dos orçamentos monetários preparados pelo Banco Central da República do Brasil, (ii) definição dos patamares de recolhimento compulsório, (iii) definição das condições para operações de redesconto e (iv) a disciplina do crédito financeiro. 
A utilização dessas ferramentas deve ser definida pelo CMN tendo em vista os objetivos traçados no artigo $3^{\circ}$. Significa dizer, portanto, que as diretrizes do CMN e sua operacionalização pelo BCB devem não apenas procurar manter estabilidade de preços e a higidez do sistema financeiro, mas principalmente implementar ações positivas no sentido de fomentar o desenvolvimento nacional e reduzir a desigualdade entre regiões. Tanto a Constituição quanto a Lei entendem que o sistema financeiro tem papel central nesse processo.

Cabe notar aqui que a preocupação com o desenvolvimento regional não envolve apenas mecanismos de controle qualitativo do crédito. Instrumentos de controle tipicamente quantitativos como a taxa de juros, o depósito compulsório e o redesconto podem ser utilizados de modo qualitativo, procurando diferenciar os patamares e requisitos por regiões. No caso dos depósitos compulsórios, há previsão expressa nesse sentido, conforme dicção do inciso XIV do artigo 4, e III do artigo $10^{201}$. Além disso, outra disposição expressando a preocupação da Lei com o desenvolvimento regional encontra-se o artigo 29, que determina que as "instituições financeiras privadas deverão aplicar, de preferência, não menos de $50 \%$ (cinqüenta por cento) dos depósitos do público que recolherem, na respectiva Unidade Federada ou Território."

Uma exame detido da sistemática da Lei 4.595/64 não deixa dúvidas de que o crédito financeiro deverá ser regulamentado pelas autoridades monetárias, que deverão instrumentalizar tanto a política monetária - especialmente as ferramentas de depósito compulsório e redesconto - quanto a regulação financeira - e a consequente físcalização para que os objetivos traçados no artigo $3^{\circ}$ sejam promovidos (no conjunto que aqui denominamos de regulação monetária). Ganha especial destaque na sistemática da Lei a questão do desenvolvimento regional, que deve "orientar a aplicação dos recursos das instituições financeiras, quer públicas, quer privadas". Nesse contexto, o BCB, tido como órgão executor, deveria observar as normas exaradas pelo $\mathrm{CMN}$ e procurar, a partir da

\footnotetext{
201 "XIV - Determinar recolhimento de até 60\% (sessenta por cento) do total dos depósitos e/ou outros títulos contábeis das instituições financeiras, seja na forma de subscrição de letras ou obrigações do Tesouro Nacional ou compra de títulos da Dívida Pública Federal, seja através de recolhimento em espécie, em ambos os casos entregues ao Banco Central do Brasil, na forma e condições que o Conselho Monetário Nacional determinar, podendo este:

a) adotar percentagens diferentes em função;

- das regiões geo-econômicas;

- das prioridades que atribuir às aplicações;

- da natureza das instituições financeiras; “
} 
disciplina constitucional, legal e regulamentar, executar a política monetária e de crédito e a fiscalização das instituições financeiras de modo a concretizar os objetivos traçados.

Por fim, deve-se ter presente desde já que a disciplina constitucional e a Lei 4.595/64 estabeleceram um papel ativo e central ao sistema financeiro e seus órgãos no processo de desenvolvimento nacional e regional. Significa dizer que esses órgãos devem ter papel transformador - dentro do espírito da Constituição Econômica - e não de manutenção do status quo ${ }^{202}$. Contrariamente, conforme se passa a discutir no próximo item, a atuação do CMN e do BCB nas últimas duas décadas procurou limitar o papel das autoridades monetárias e do regulador bancário à garantia da estabilidade de preços e higidez das instituições bancárias.

O argumento central deste trabalho procura demonstrar que essa escolha da política monetária e de crédito ignora a dogmática jurídica estabelecida e o espírito transformador da Constituição Econômica, transformando suas disposições quanto ao sistema financeiro em verdadeira constituição liberal, que procura unicamente a manutenção do status quo, aqui entendido como estabilidade de preços e financeira. Dessa forma, a postura das autoridades monetárias tem sido no sentido de limitar o seu papel à garantia do status quo/estabilidade, relegando a outras políticas públicas o papel transformador. $\mathrm{O}$ argumento deste trabalho é no sentido de observar que, embora a estabilidade seja relevante para o desenvolvimento macroeconômico, ela não é um fim em si mesmo, cabendo à autoridade monetária a assunção de um papel ativo no sentido de dirigir ou influenciar a atividade dos particulares. Neste trabalho, demonstra-se que essa atuação é especificamente necessária diante da preocupação constitucional com a redução das desigualdades regionais dado que, como visto acima, numa economia como a brasileira o livre jogo do mercado tende à

\footnotetext{
${ }^{202}$ Geraldo Camargo Vidigal, pouco antes da promulgação da Lei 4.595/64, já apontava esse papel como imprescindível no caso brasileiro: "O Banco Central típico das nações democráticas contemporâneas, orientadas para o bem estar de suas populações, mas respeitadoras da liberdade de iniciativa priva, na medida em que sirvam a esse bem-estar, é instrumento distinto do que descrevemos no número 19 supra. Não pretende ele concentrar e distribuir todos os recursos nacionais, mas não se satisfaz em ser mero guardião de encaixes e reservas, sem poder disciplinador. Não aceita ser uma peça das frias engrenagens de planejamento global coletivista, mas repudia por igual a superstição dos infalíveis mecanismos automáticos do mercado. Dispõe-se a agir nos mercados nacionais e internacionais pelas operações de mercado aberto, pela compra e venda do ouro, pela manipulação da taxa de juros: mas reclama também poder para graduar o volume dos meios de pagamento e exercer influência sobre sua distribuição, mediante fixação de níveis variáveis e obrigatórios de encaixe, bem como faixas variáveis a controle seletivos de redesconto." (Disciplina dos órgãos de direção monetária, Tese de Livre Docência, Universidade de São Paulo, 1964, pp. 13 e 14).
} 
concentração do crédito e intensificação das condições de desenvolvimento regional desigual.

Os parâmetros aqui delineados devem integrar a análise da accoutability das autoridades monetárias no Brasil. É necessário trazer tais pontos ao debate público para que as autoridades monetárias sejam supervisionadas e cobradas a esse respeito. Contudo, o que se observa é a total ausência desse debate na esfera pública. Como se passa a discutir, as autoridades monetárias ignoram a questão do desenvolvimento regional e não têm qualquer preocupação em justificar seus atos, ou melhor, a inação a esse respeito.

\subsection{Entre autonomia (de fato) e cientificização: a superação da dogmática jurídica}

Como destacado no item 2.5 acima, a assunção da moeda como neutra no longo prazo, qualificando-a como mero intermediário de trocas sem nenhum efeito sobre a decisão dos agentes econômicos acerca de investimentos, produção ou consumo, tem resultado no desenvolvimento e consolidação de uma ortodoxia econômica que tem preconizado, como "receita" de melhores práticas internacionais nos últimos 20 anos, que as autoridades monetárias - em geral, já identificadas diretamente como bancos centrais devem limitar sua atuação unicamente à busca da manutenção da estabilidade macroeconômica.

Além disso, diante do risco sistêmico e da peculiaridade da atividade bancária, que pode expor a riscos os consumidores e as próprias instituições, essa ortodoxia tem também reconhecido a necessidade de um regulador (que pode ou não ser o próprio banco central) para conduzir as regulações prudencial e sistêmica com o fim específico de manutenção da higidez do sistema.

Por fim, a terceira parte da receita procura vincular a ideia de autonomia do banco central com estabilidade. Em outras palavras, a autonomia seria necessária para a estabilidade e, além disso, assume-se que autonomia estaria necessariamente relacionada a uma atuação limitada à garantia da estabilidade como meta central. 
A atuação do BCB e do CMN tem sido influenciada por essas teorias e, por consequência, a política monetária e de crédito e a regulação bancária (que aqui denominamos conjuntamente de regulação monetária) têm sido limitadas a esses dois objetivos no Brasil - estabilidade de preços e financeira, ao mesmo tempo em que um processo de autonomização - que, possivelmente, já apresenta uma evolução no sentido da cientificização - das autoridades monetárias foi deflagrado.

Desde a crise inflacionária nos anos 1980, as autoridades monetárias brasileiras têm destinado esforços e concentrado suas ações no sentido de conter a inflação. Nesse sentido, a política monetária no país foi marcada por uma série de planos econômicos que não obtiveram sucesso na contenção do processo inflacionário, os denominados Planos Cruzado (1986), Bresser (1987), Verão (1989), Collor I (1990) e Collor II (1991). Somente o Plano Real, de 1994, estabeleceu um programa de estabilização capaz de conter a crise inflacionária em curso. Nesse programa, a taxa de câmbio constituía o preço-âncora (ancoragem cambial) e a taxa de juros foi instrumentalizada como meio de incentivar a entrada de capital estrangeiro no curto prazo, procurando assim equilibrar a balança comercial $^{203}$.

No início do Plano Real, como o fluxo de capital estrangeiro ultrapassava o necessário para o equilíbrio da balança comercial, a acumulação de reservas internacionais deu lugar a uma considerável apreciação da taxa de câmbio, resultando então em déficit da balança comercial. A dependência do capital estrangeiro de curto prazo deixou o país em situação de fragilidade externa, expondo o país a contágios quanto às crises do Sudeste Asiático, mexicana e russa. Esses ataques especulativos ao Real resultaram na contração das reservas cambiais e obrigaram as autoridades monetárias a incrementar, ainda mais, a taxa de juros para incentivar a entrada de capitais.

Em função da intensa crise cambial vivenciada pelo país, as autoridades monetárias procederam a uma revisão do programa de estabilização. O país passou a adotar o câmbio flutuante, o que resultou em expressiva desvalorização da taxa de câmbio e originou

\footnotetext{
${ }^{203}$ A exposição do programa de estabilização que acompanhou o Plano Real se baseia em Philip Arestis, Luiz Fernando de Paula e Fernando Ferrari-Filho, A nova política monetária: uma análise do regime de metas de inflação no Brasil, in Economia e Sociedade v. 18, n. 1 (2009), pp. 7-9.
} 
pressões inflacionárias substantivas, em razão de um denominado efeito pass-through da elevação do câmbio para os preços domésticos. Diante desse quadro, as autoridades monetárias, em junho de 1999, por meio de Decreto Presidencial, passaram a adotar o regime de metas de inflação, ao mesmo tempo em que a taxa de juros sofreu constantes elevações para acomodar a desvalorização cambial.

O regime de metas de inflação é uma estratégia de condução da política monetária em linha com a ortodoxia econômica referida acima, em que a autoridade monetária estabelece um compromisso institucional com a meta estabelecida, reforçando assim a estabilidade monetária como seu principal objetivo ${ }^{204}$. No regime brasileiro, cabe ao $\mathrm{CMN}$ estabelecer as metas, conforme propostas pelo Ministro da Fazenda.

A meta é estabelecida com a duração de um ano para o ano corrente e os dois próximos anos, e se baseia no Índice Nacional de Preços ao Consumidor Amplo (IPCA). Um intervalo de tolerância entre 2 e 2,5 pontos percentuais acima ou abaixo da meta é estabelecido. Considera-se êxito quando a variação anual do IPCA permanece dentro do intervalo estabelecido. Quando a inflação ultrapassa o intervalo, o presidente do BCB deve escrever uma carta pública ao Ministro da Fazenda explicando os motivos para o fracasso da política e delineando as medidas propostas para recuperar a meta.

O principal instrumento à disposição do $\mathrm{BCB}$ para atingir a meta é a taxa de juros de curto prazo, que tem se mantido em patamares elevados, numa nítida política contracionista baseada em juros altos (acompanhada, evidentemente, por óbices ao crescimento e ao investimento, já que juros altos desaquecem a economia e aumentam o déficit público) $)^{205}$.

O regime de metas de inflação é indicativo da adoção pelas autoridades monetárias brasileiras da estabilidade de preços como o principal - e, talvez, único - objetivo da política monetária. No mesmo sentido, a regulação bancária também tem sido

\footnotetext{
${ }^{204}$ Vale notar que o regime de metas de inflação foi instituído por meio de um Decreto presidencial. No entanto, a competência atribuída pela Constituição Federal para regulamentar essa questão é do Congresso Nacional, que as delegou ao CMN. Nesse sentido, quer parecer imprópria a instituição desse regime por meio de Decreto.

${ }^{205}$ Nesse sentido ver André de Melo Modenesi, Política monetária no Brasil pós Plano Real (1995-2008): um breve retrospecto, in Economia \& Tecnologia 21 (2010), p. 27.
} 
desenvolvida em sintonia com os dogmas da ortodoxia econômica, limitando-se a procurar garantir a higidez financeira. O ex-presidente do BCB evidencia essa concepção, destacando que o papel do BCB no desenvolvimento se concentra em manter a estabilidade macroeconômica e higidez financeira ${ }^{206}$ :

\begin{abstract}
"Em suma, a contribuição do Banco Central para o desenvolvimento do Brasil reside primordialmente no simples cumprimento de seus dois principais objetivos, quais sejam: zelar pela estabilidade da moeda e pela qualidade e segurança da intermediação financeira". ${ }^{207}$
\end{abstract}

As autoridades monetárias confiam que, garantindo a estabilidade de preços, a higidez financeira e algum grau de concorrência, o sistema bancário proporcionaria resultados superiores àqueles que seriam proporcionados por qualquer outra política de intervenção. Assim, as autoridades monetárias contribuiriam para o desenvolvimento mediante unicamente a garantia do status quo, aqui entendido como estabilidade macroeconômica. Segundo essa concepção, às demais políticas públicas caberia a função transformadora, embora ela reverbere também sobre a formulação e desempenho de outras políticas, como a fiscal ${ }^{208}$.

\footnotetext{
206 A liquidação, privatização ou transformação de diversos bancos públicos estaduais em agências de fomento no contexto do PROES deve ser mencionada como um elemento relevante no cenário aqui descrito. Por meio dessas medidas implantadas pelo BCB e outras relacionadas ao endividamento dos Estados, o BCB concentrou ainda mais sua capacidade de gestão da política monetária, limitando a capacidade de expansão da base monetária de diversos Estados. Dessa forma, o poder de gestão da base monetária ficou concentrado na União, representado pelo BCB. Esse fenômeno é relevante e tem consequências sobre a dinâmica de desenvolvimento regional, merecendo ser examinado em detalhes, inclusive para que a noção de Federalismo seja incorporada à análise. No entanto, dado que este trabalho tem como escopo principal examinar a intervenção do Estado sobre o sistema bancário privado, não será realizada uma abordagem detida dessa questão. Uma abordagem interessante da perspectiva da ciência política pode ser encontrada em Lourdes Sola, Christopher Garman e Moises Marques, Central Banking, Democratic Governance and Political Authority: the Case of Brazil in a Comparative Perspective, in Revista de Economia Política, vol. 18, n. 2 (1998), pp. 106-131.

${ }^{207}$ Armínio Fraga, O papel do Banco Central no século 21, op. cit., pp. 21-3.

${ }^{208}$ Nesse sentido, “no Brasil pós-1988 há, portanto, a consolidação da supremacia do orçamento monetário, ou seja, a garantia do custo da moeda (definido pelo Banco Central e pelo Conselho de Política MonetáriaCOPOM, à margem do Congresso Nacional), voltado para a estabilidade monetária, sobre o orçamento fiscal. A concepção de 'orçamento-programa', há muito difundida nos meios financeiros brasileiros, perdeu, inclusive, todo o seu sentido, se é que alguma vez realmente o teve. Afinal, o próprio orçamento fiscal perdeu a supremacia do controle e da determinação da política fiscal. Entre 1964 e 1988, isto devia-se ao descontrole do orçamento monetário, escondido na conta-movimento do Banco do Brasil e no orçamento das empresas estatais. Após 1988, o controle do orçamento monetário provocou a subordinação das políticas fiscais (e do 'orçamento-programa') à política de estabilização monetária” (Gilberto Bercovici e Luís Fernando Massoneto, A Constituição Dirigente invertida: a blindagem da constituição financeira e a agonia da Constituição Econômica, Separata do Boletim de Ciências Econômicas XLIX (2006), pp. 15-16. Sobre esse ponto, ver também Geraldo Camargo Vidigal, Direito Monetário, São Paulo: IBCB, 1995, pp. 144-155
} 
Essa concepção reflete-se sobre a atuação do $\mathrm{BCB}$, que passa a preconizar e a adotar uma política de intervenção limitada. Os diversos relatórios emitidos pelo BCB evidenciam uma tendência no sentido de eliminar quaisquer modalidades de intervenção que excedam a regulação prudencial/sistêmica e a política monetária baseada estritamente no regime de metas. Mecanismos de intervenção como o direcionamento de crédito, por exemplo, são apontados como ineficientes e capazes de tornar a atuação dos bancos privados mais onerosa.

Nesse sentido, o BCB apontou pela primeira vez, em relatório de 2003, o crédito direcionado como uma das três principais causas para os altos juros cobrados pelas instituições financeiras e pelos elevados spreads $^{209}$ identificados $^{210}$. Segundo esse argumento , a obrigação de destinação de $65 \%$ dos depósitos em cadernetas de poupança a financiamentos imobiliários e $25 \%$ dos depósitos à vista para financiamento no setor rural seria ineficiente, pois subverteria a lógica privada levando recursos a investimentos que os bancos não desejariam realizar. Como medida compensatória, os bancos incrementariam os custos de outros financiamentos, o que, no agregado, resultaria em spreads maiores. Interessante notar que esse argumento surge a despeito da limitação patente dos mecanismos de crédito direcionado que se encontram atualmente em curso sobre o sistema bancário, posto que correspondem a apenas $8,5 \%$ aproximadamente do total de recursos disponíveis no sistema bancário privado ${ }^{211}$.

Essa contestação dos mecanismos de crédito direcionado se replica quanto à qualquer outra forma ou incentivo para alocação de recursos pelas instituições privadas. Assim, a despeito do quanto observado no passado, atualmente os mecanismos de depósito compulsório e redesconto também não têm servido como meios de se incentivar determinadas aplicações ou investimentos em setores ou regiões específicos. Ao contrário, o BCB tem atuado no sentido de ampliar o crédito livre, ou seja, aquele que deverá ser utilizado pelas instituições bancárias da forma que melhor lhes pareça segundo a lógica privada de mercado, sem quaisquer direcionamentos ou influências do Estado. A formulação dos instrumentos de regulação e supervisão financeira também não são

\footnotetext{
${ }^{209}$ Denomina-se "spread" a diferença entre a taxa de juros paga pela instituição financeira para a captação de recursos e a taxa de juros cobrada nos empréstimos realizados por essas instituições.

${ }^{210}$ Banco Central do Brasil, Políticas de crédito no Brasil, 2004.

211 Ernani Teixeira Torres Filho, Crédito direcionado e direcionamento de crédito: situação atual e perspectivas, in Revista do BNDES 25 (2006), p. 46.
} 
debatidos à luz dos objetivos impostos ao CMN pela Lei 4.595/64, e instrumentos previstos em lei para direcionamento de crédito ou exigência de que parcela expressiva dos recursos obtidos em determinada região permaneçam nela são desconsiderados ${ }^{212}$.

Essa atuação é contrária à Constituição Federal e à Lei 4.595/64, por procurar apenas a preservação do status quo sem gerar qualquer alteração. A Constituição Federal pretende a mudança e coloca o sistema financeiro no centro do processo de alteração do status quo. E isso é particularmente importante no caso do desenvolvimento regional, já que há evidências teóricas e empíricas no sentido de que uma atitude passiva do Estado apenas perpetua a condição desigual.

Nesse contexto, na dimensão que Jacome denominou de independência econômica $^{213}$, cumpre apontar que as autoridades monetárias no Brasil não têm goal independence. Ao contrário, a Constituição Federal e a Lei 4.594/64 incluíram a regulação monetária como uma das dimensões centrais da política econômica do Estado, traçando as metas da ação das autoridades monetárias.

A esfera de autonomia econômica das autoridades monetárias limita-se à certo grau de autonomia operacional (instrument independence) para elaboração e manejo dos instrumentos que devem levar ao cumprimento das metas. No entanto, no caso brasileiro, a independência operacional é formalmente limitada pela subordinação do $\mathrm{BCB}$ ao $\mathrm{CMN}$, cuja composição compreende os Ministros de Estado da Fazendo e Planejamento, o que ratifica a percepção de que as diretrizes da regulação monetária devem estar em linha com a política econômica do governo. Em outras palavras, o $\mathrm{CMN}$, órgão eminentemente político, pode influenciar a seleção e conformação dos instrumentos à disposição do BCB para execução da regulação monetária, o que limita, formalmente, a noção de independência técnica (a ênfase na limitação meramente formal se dá em razão da

\footnotetext{
${ }^{212}$ Lei 4.595/64:

“Art. 29. As instituições financeiras privadas deverão aplicar, de preferência, não menos de 50\% (cinqüenta por cento) dos depósitos do público que recolherem, na respectiva Unidade Federada ou Território.

$\S 1^{\circ}$ O Conselho Monetário Nacional poderá, em casos especiais, admitir que o percentual referido neste artigo seja aplicado em cada Estado e Território isoladamente ou por grupos de Estados e Territórios componentes da mesma região geoeconômica."

${ }^{213}$ Luis Jácome, Legal Central Bank Independence and Inflation in Latin America During the 1990s, op. cit. pp. 8-9.
} 
abstenção do CMN na prática, o que tem garantido ao BCB ampla autonomia operacional de fato, como se examina abaixo).

Dessa forma, cumpre às autoridades monetárias justificar suas ações tendo em vista as metas estabelecidas, evidenciando e fundamentando seus atos e escolhas a partir dos parâmetros definidos como objetivos por meio de regras jurídicas. No entanto, é possível observar que não há qualquer preocupação por parte das autoridades monetárias brasileiras em justificar como os instrumentos atualmente adotados têm contribuído para a concreção da meta desenvolvimento regional. A questão do desenvolvimento regional e do papel atribuído às autoridades monetárias pela Constituição Federal e pela Lei 4.595/64 é simplesmente ignorada pelo $\mathrm{CMN}$ e pelo $\mathrm{BCB}$. Os diversos relatórios emitidos pelo $\mathrm{BCB}$ não contêm qualquer ponderação acerca da questão regional ou debate sobre possíveis ações para redução da concentração do crédito financeiro. A única série de documentos com algum viés regional é o Boletim Regional, cuja primeira edição é de outubro de 2007. Esse boletim trimestral apenas examina dados de economia real (como emprego, vendas no varejo, produção da indústria, etc) segmentados pelas diferentes regiões do país, sem que haja, no entanto, qualquer exame das condições do setor bancário regionalmente ou debate sobre ações regionais do $\mathrm{BCB}$ ou justificativas para a inação ${ }^{214}$.

$\mathrm{A}$ atuação do $\mathrm{CMN}$ e do $\mathrm{BCB}$ nos últimos anos revela verdadeira supressão ou modificação dos objetivos das autoridades monetárias no Brasil, que, mesmo cientes do mandato legal diverso, alçaram a estabilidade de preços e financeira a seus únicos objetivos, fundamentando essa verdadeira reforma institucional no alegado cientificismo de suas escolhas e ações.

É interessante notar que as autoridades monetárias têm sim ciência de que a dogmática jurídica deve confluir para a determinação de suas ações e, especialmente no caso brasileiro, ela não corrobora a limitação de seu papel à garantia da estabilidade. Nesse sentido, Fernando Cardim Carvalho relata, a partir de notícias veiculadas no extinto jornal Gazeta Mercantil, que Pedro Malan, quando Presidente do Banco Central, pretendia propor

${ }^{214}$ As edições do Boletim Regional podem ser encontradas no site do BCB: www.bcb.gov.br. 
a inserção de emenda constitucional dispondo que a estabilidade de preços seria o principal objetivo da política monetária ${ }^{215}$.

O ponto central aqui não é defender a desconsideração da estabilidade de preços. $\mathrm{Na}$ verdade, essa é sem dúvida uma das metas centrais de atuação das autoridades monetárias, sendo expressamente prevista no art. $3^{\circ}$ da Lei 4.595/64. Além disso, a Constituição Federal demonstra nítida preocupação com esse ponto, vedando que o BCB financie diretamente o Tesouro Nacional (art. 154, $\S 1^{\circ}$ ). É comum a crítica que aponta para a possibilidade de financiamento indireto por meio da compra de títulos da dívida pública. No entanto, o $\$ 2^{\circ}$ do art. 164 permite a compra de títulos da dívida pelo BCB apenas para fins de implementação da política monetária e controle da taxa de juros, vedando o financiamento público por meio desse instrumento. Assim, a compra de títulos da dívida com o fim de financiar o Tesouro Nacional, como feito no passado, seria certamente um abuso dessa prerrogativa, violando a Constituição Federal e também a posteriormente editada Lei de Responsabilidade Fiscal.

Dessa forma, a estabilidade monetária é sim um dos objetivos centrais da ação das autoridades monetárias, o que pode se depreender da disciplina constitucional e legal. No entanto, não se pode resumir a regulação monetária a esse ponto. A Constituição e a Lei estabeleceram outras metas que devem conviver com a meta da estabilidade. Portanto, a questão central não é a priorização da estabilidade de preços, mas sim a total desconsideração das demais metas (dentre elas o desenvolvimento regional). A eleição de prioridades dentre as diversas metas é sim possível, desde que justificada substantivamente $^{216}$. Além disso, as prioridades devem ser revistas constantemente e podem conviver com diversas ações relacionadas às outras metas, especialmente para que, com o tempo e com a experiência, seja possível o desenvolvimento de mecanismos de convivência entre as diversas metas, que devem ser testados e seus resultados expostos publicamente (a ideia de "learning by doing" é fundamental nesse processo).

\footnotetext{
215 Relato extraído do texto A independência do Banco Central e a disciplina monetária: observações céticas, in Revista de Economia Política, vol. 15, n.4 (1995), p. 135.

${ }^{216}$ Cumpre observar que a eleição da estabilidade monetária como prioridade ao se estabelecer o regime de metas de inflação não deveria se dar por meio de Decreto Presidencial. Afinal, como debatido acima, o Presidente da República não tem competência formal para dispor sobre questões de política monetária. Essa competência é do Congresso Nacional e foi delegada ao CMN.
} 
É nesse sentido que a necessidade de maior accountability ganha força, especialmente para que questões substantivas sejam debatidas de modo mais amplo. Isso porque a accoutability tem sido muito mais procedimental que substantiva. Nas décadas de 1990 e 2000, as autoridades monetárias ganharam autonomia política de fato e passaram a desenvolver o discurso da cientificização. Nesse sentido, pode-se notar um insulamento das autoridades monetárias no Brasil, que se distanciaram dos demais Poderes com um discurso baseado na complexidade da gestão monetária. Esse discurso baseado no diferencial de sua capacitação técnica reverberou com intensidade, garantido às autoridades monetárias brasileiras condições institucionais para atuar com ampla liberdade e sem questionamentos efetivos de outras esferas.

Dessa forma, ainda que haja avanços quanto à transparência do $\mathrm{BCB}$, não existe uma discussão substantiva sobre sua atuação. O foco exclusivo na estabilidade monetária é, talvez, a face mais caricatural do insulamento do BCB em função do alegado cientificismo de sua atuação. Essa dimensão da accountability é fundamental e merece ser explorada. No entanto, agentes de mercado e os Poderes da República não têm participado desse debate.

Como se passa a discutir, o diálogo entre autoridades monetárias e Poderes Executivo, Legislativo e Judiciário foi marcado pelo discurso da autonomia, que vem ganhando a dimensão de cientificização, resultando numa situação de fato em que incide negligenciável questionamento formal ou substantivo das ações do BCB. Nota-se então que, contrariamente à disciplina jurídica aplicável, há intensa independência de fato quanto aos objetivos e meios da atuação das autoridades monetárias. 


\subsection{Insulamento da burocracia do BCB e a abstenção (ou ratificação) pelos Poderes da República: a força do discurso da estabilidade}

Em síntese, do ponto de vista jurídico-formal, as autoridades monetárias no Brasil têm independência financeira (dado o regime de autarquia do $\mathrm{BCB}$ ), limitada independência econômica e baixa independência política ${ }^{217}$.

A independência econômica das autoridades monetárias é constrangida pela inexistência de goal independence (as metas e objetivos das autoridades monetárias são definidas no plano político e consubstanciadas em normas jurídicas) e pela limitada autonomia de meios (instrument independence). Isso porque o $\mathrm{CMN}$ é o principal responsável pela elaboração das diretrizes e conformação dos instrumentos da regulação monetária, sendo um órgão eminentemente político, responsável por "coordenar as políticas monetária, creditícia, orçamentária, fiscal e da dívida pública, interna e externa" (art. 4, VII, da Lei 4.595/64). Dessa forma, o órgão técnico, BCB, sendo mero executor da política, tem sua autonomia de meios limitada pelas decisões do CMN.

Por sua vez, a independência política de jure é baixa. O CMN é composto por três membros, sendo dois deles Ministros de Estado da Fazenda e do Planejamento. O terceiro membro é o Presidente do BCB que, assim como os outros quatro diretores da instituição, são demissíveis “ad nutum” pelo Presidente da República ${ }^{218}$.

Portanto, depreende-se que do ponto de vista jurídico-formal, as autoridades monetárias no Brasil integram a política econômica do Estado e devem com ela se coordenar. A divisão de atribuições e composição dos cargos evidencia que a regulação monetária deve ser acompanhada de perto e influenciada pelo Poder Executivo, com a atuação direta de dois Ministros de Estado. Além disso, o Congresso Nacional, que

\footnotetext{
${ }^{217}$ Essa tipologia foi extraída de Luis Jácome, Legal Central Bank Independence and Inflation in Latin America During the 1990 s, op. cit. pp. 8-9.

${ }^{218}$ Diferencia-se aqui a autonomia política de fato, conquistada mediante a relação institucional entre a autoridade monetária e as demais organizações, e autonomia de jure, em que mecanismos jurídicos como mandato fixo ou ausência de instâncias revisoras são estabelecidos para incrementar a esfera de autonomia do órgão.
} 
delegou as competências, deve ser responsivo e examinar o cumprimento das metas por ele estabelecidas.

No entanto, o entrelaçamento entre os discursos da estabilidade monetária e da autonomia têm levado a uma realidade fática muito distinta, especialmente pela força que o discurso da estabilidade ganhou no país em face da ainda ameaçadora crise inflacionária, fazendo com que a atividade do BCB tenha sua complexidade técnica exaltada a ponto próximo de perpetuar a cientificização identificada na teoria e limitar a accoutability substantiva (voltada ao debate dos parâmetros e metas da ação do BCB).

Desse modo, possível afirmar que a autoridade monetária no Brasil tem ganhado autonomia em razão da estabilidade, e não o contrário:

\begin{abstract}
"We conclude for the case of Brazil that at least one of the condititions for legitimization of Central Bank authority has been achieved to the extent that economic stabilization became a first order public good for the populace at large and the existing government.

(...) The recent centralization of monetary authority in the Central Bank yields a final and valuable analytical lesson. The Central Bank in Brazil has been able to gain increasing discipline over the monetary system in part because of the economic stabilization plan - not the other way around, as predicted by conventional wisdom." 219
\end{abstract}

O Poder Executivo contribui para a cientificização ao evitar um diálogo aberto com o BCB. Os Ministros da Fazenda e do Planejamento, que compõem o CMN junto com o Presidente do BCB e deveriam formular a política monetária, de crédito e as diretrizes da regulação financeira, na prática, têm grau diminuto de atuação. O CMN tem relegado as decisões principais ao $\mathrm{BCB}$ e ao $\mathrm{COPOM}$, órgão interno à estrutura do $\mathrm{BCB}$. Do mesmo modo, Comissões Consultivas compostas por representantes de diversas entidades do sistema financeiro e de outros setores, previstas no art. 7 da Lei 4.595/64, não têm atuação.

Por sua vez, a inação do Poder Legislativo, que quase 25 anos após a promulgação da Constituição Federal ainda não promulgou nova Lei para disciplina do sistema financeiro, corrobora o insulamento das autoridades monetárias. Nesse sentido, o Poder Legislativo, a despeito de ser o detentor da prerrogativa para formular a gestão da moeda,

\footnotetext{
${ }^{219}$ Lourdes Sola, Christopher Garman e Moises Marques, Central Banking, Democratic Governance and Political Authority: the Case of Brazil in a Comparative Perspective, op. cit., p. 129.
} 
conforme disposição constitucional, e ser aquele que delega funções às autoridades monetárias, tem tido atuação muito tímida na fiscalização do cumprimento do mandato por ele conferido.

Mais do que mera abstenção, é possível identificar uma série de ações de iniciativa do Poder Executivo no sentido de consolidar a autonomia política do BCB, que foram posteriormente confirmadas pelo Congresso Nacional e pelo Supremo Tribunal Federal. Além disso, a força do discurso da estabilidade aliado ao discurso da cientificização tem contribuído para que autonomia operacional do BCB se intensifique (dado que o CMN tem atuado pouco) e, em certa medida, transforme-se em autonomia de metas.

Uma dimensão importante para o exame dessas ações é a análise da jurisprudência do Supremo Tribunal Federal. Um exame qualitativo dos casos apreciados pelo STF em matéria de regulação monetária indica que a Corte contribuiu para o processo de insulamento da burocracia monetária, confirmando em larga medida o discurso da autonomia. As decisões do STF nessa seara são marcadas por argumentos de governabilidade que refletem nítida repulsa a possíveis ameaças à estabilidade monetária ou pela exaltação da complexidade e especificidade das decisões tomadas no âmbito da política monetária ou da regulação financeira que, na minha análise, superaram argumentos pautados por uma lógica dogmático-formal ${ }^{220}$.

Do exame da jurisprudência do Tribunal no período após a promulgação da Constituição de 1988, seis casos de controle concentrado de constitucionalidade são particularmente relevantes para os fins deste trabalho, e podem ser divididos em dois

\footnotetext{
${ }^{220}$ Não é objetivo deste trabalho fazer uma análise exaustiva da jurisprudência do STF. Nem se pretende transformar a presente dissertação, eminentemente teórica e pautada pelo método dialético, num estudo de casos. No entanto, durante o desenvolvimento do trabalho passei a notar pontos de convergência entre os elementos aqui estudados e pesquisas que realizei anteriormente acerca da jurisprudência do STF. Essas pesquisas tinham objetos distintos daquele definido para o presente estudo, mas partiam de uma base material comum, o que torna parte das conclusões passíveis de diálogo neste texto. Por isso, procedi a uma releitura de pontos pesquisados anteriormente, mas agora sob à luz do tema deste trabalho e passo neste item a expor o resultado dessa releitura. Para fins de total clareza, anoto que a jurisprudência do STF já foi objeto de minha análise, sob outros perspectivas que se comunicam com a aqui apresentada, nos seguintes trabalhos: Legitimidade e governabilidade na regulação do sistema financeiro - uma análise da jurisprudência do STF, in Revista Direito GV n. 8 (2009); Legitimidade e governabilidade na regulação do sistema financeiro: crise inflacionária, reforma constitucional e estabilidade econômica na jurisprudência do STF, in COUTINHO, Diogo e VOJVODIC, Adriana. Jurisprudência Constitucional: como decide o STF?, São Paulo: Malheiros, 2009; O papel do STF na regulação do Sistema Financeiro Nacional, Monografia para conclusão da Escola de Formação da Sociedade Brasileira de Direito Público - SBDP, , 2007, disponível in http://www.sbdp.org.br/ver_monografia.php?idMono=103.
} 
grupos distintos $^{221}$. No primeiro grupo, o STF examinou atos dos Poderes Executivo e Legislativo que conferiram maior autonomia econômica ao BCB. No segundo grupo, os atos analisados coferiam maior autonomia política de direito.

No primeiro grupo, o STF afastou a possibilidade de que os juros praticados na economia fossem pautados ou diretamente influenciados por regramentos ou instituições que não as autoridades monetárias. Além disso, argumentos de governabilidade foram muito prementes e manifestamente influenciaram a decisão do Tribunal, que não apenas ratificou mas reforçou a competência do $\mathrm{CMN}$ e do BCB para a disciplina da moeda e das instituições financeiras. No último grupo, o STF decidiu questões relevantes sobre a organização institucional das autoridades monetárias e suas atribuições, enfatizando o caráter técnico e necessidade de insulamento da burocracia.

A análise da atuação do Poder Judiciário é particularmente importante neste trabalho. Afinal, o Poder Judiciário apresenta como uma de suas mais importantes funções institucionais garantir a calculabilidade e previsibilidade do direito, mediante a preservação das premissas e princípios jurídicos, constituindo assim o lócus, por essência, de preservação da legalidade e prevalência do raciocínio jurídico. Por sua vez, o sistema bancário é um ilustrativo exemplo de setor composto e pressionado por decisões eminentemente econômicas, que por seu grau muitas vezes elevado de complexidade e especificidade técnica, terminam por se postar atrás de uma blindagem técnica.

Na abertura democrática no Brasil, em meados da década de 1980, o país encontrava-se inserido em contexto de hiperinflação, acompanhado pela desestabilização do padrão monetário e das finanças públicas. A Constituição Federal de 1988 foi

\footnotetext{
${ }^{221}$ A seleção dos acórdãos aqui analisados partiu de pesquisas realizadas anteriormente e referidas na nota 220. A partir do universo de acórdão antes pesquisados, procedi a uma análise qualitativa para selecionar aqueles que efetivamente seriam de interesse para o presente trabalho. Vale mencionar que não foram incluídos acórdãos relacionados a controle difuso. A escolha pelas ações diretas de inconstitucionalidade justifica-se pela análise mais precisa e objetiva do ato normativo questionado, sem que peculiaridades do caso concreto tenham que ser consideradas. Além disso, no controle difuso, as ações relevantes para o exame do papel da autoridade monetária dizem respeito aos diversos recursos extraordinários já julgados pelo STF acerca dos planos econômicos. Embora contenham elementos interessantes sobre a atuação das autoridades monetárias, a discussão dos planos econômicos tem conteúdo específico e muito limitado à atividade legislativa (do Congresso Nacional) sobre a moeda, ultrapassando o escopo da análise aqui proposta, que procura focar a delimitação dos limites instrumentais e metas das autoridades monetárias. Para uma análise dos casos envolvendo a discussão sobre planos econômicos, ver Camila Duran-Ferreira, Direito e regulação econômica: o controle dos planos de estabilização monetária pelo Supremo Tribunal Federal - um enfoque empírico, Dissertação de Mestrado, Faculdade de Direito da Universidade de São Paulo, 2008.
} 
promulgada nesse contexto de crise econômica, que tornava árduo o nascimento de um padrão decisório democrático no governo brasileiro e a fixação de um plano de desenvolvimento econômico para a nação, já que a preservação da governabilidade demandava medidas céleres, drásticas e a curto prazo. A nova lei máxima do país deveria ser capaz de institucionalizar a transição democrática brasileira, restabelecendo o império da lei, e ao mesmo tempo conviver com a lógica econômica da eficiência e dos resultados, despreocupada com a qualificação dos procedimentos e meios utilizados nas ações estatais voltadas à estabilização da moeda e da balança de pagamentos do país, o que dependia em larga medida da regulação econômica das atividades desempenhadas pelo Sistema Financeiro Nacional.

Portanto, possível identificar uma tensão entre a necessidade de se limitar e superar a crise econômica vivenciada pelo país tendo em vista os anseios de desenvolvimento econômico, que resultou em uma atuação concentrada pelo Poder Executivo, mediante medidas céleres que obedeciam a uma lógica de governabilidade, em face à exigência de que essas medidas fossem legítimas a partir da perspectiva jurídica, ou seja, que respeitassem as regras estabelecidas pelo direito ${ }^{222}$.

\subsubsection{Conjuntura, lei complementar e a consolidação da autonomia econômica das autoridades monetárias ${ }^{223}$}

$A D I n^{\circ} 4-7$

Apenas sete dias após a promulgação da Constituição Federal em 05 de outubro de 1988, com uma ação direta de inconstitucionalidade foi ajuizada pelo Partido Democrático Trabalhista (PDT) para questionar ato do Presidente da República, publicado no Diário

\footnotetext{
222 A perspectiva do controle judicial como necessária para a legitimidade democrática da regulação financeira é investigadas por Jean Paul Cabral Veiga da Rocha, que examina a partir da jurisprudência do STF se a Corte tem funcionado como uma forma de controle democrático: A capacidade normativa de conjuntura no direito econômico: o déficit democrático da regulação financeira, Tese de Doutorado, Faculdade de Direito da Universidade de São Paulo, 2004.

${ }^{223}$ Estabelece-se para a citação de excertos dos acórdãos ou referência aos mesmos a indicação do número da ação direta de inconstitucionalidade seguida do número da página referida. A indicação das páginas segue a numeração estabelecida nos arquivos disponíveis no sítio eletrônico do STF, que disponibiliza o inteiro teor dos acórdãos. Portanto, a numeração se refere ao acórdão, e não a numeração individual dos votos.
} 
Oficial da União em 07 de outubro de 1988, que aprovou o Parecer SR-70 da Consultoria Geral da República ${ }^{224}$.

$\mathrm{O}$ ato do Presidente da República conferiu caráter normativo ao conteúdo do Parecer SR-70, que negava aplicabilidade imediata ao parágrafo $3^{\circ}$ do art. 192 da Constituição de 1988. Segundo preconizado no parecer, a disposição constitucional que limitava os juros reais a $12 \%$ ao ano dependeria de regulamentação por lei complementar para que fosse eficaz ${ }^{225}$. Com base nesse parecer, o BCB editou a Circular 1.365, esclarecendo aos agentes do mercado financeiro que permanecia em vigor a legislação estabelecida anteriormente à promulgação da Constituição de 1988. A limitação constitucional da taxa de juros aplicável ao mercado financeiro tornou-se então objeto de análise do STF, já que o parecer proferido pela Consultoria Geral da República terminara por frear a aplicação desse dispositivo, contrariando diversos setores da sociedade que observavam a limitação constitucional como uma restrição ao setor financeiro em favor da cidadania e dos setores produtivos, que assim conquistavam uma importante vitória contra a prática da usura ${ }^{226}$.

As autoridades financeiras e monetárias do país vislumbravam na aplicação daquele dispositivo um agravamento insustentável da crise financeira já vivenciada pelo país, que teria como conseqüências fenômenos como o fim da atividade de intermediação financeira exercida principalmente pelos bancos e a conseqüente formação de um mercado informal de crédito, a fuga de capitais, o fim do mercado de capitais, o aumento da hiperinflação e

\footnotetext{
${ }^{224}$ Conforme determinavam os artigos 22 e 23 do Decreto $n^{\circ}$ 92.889, de 1986, a aprovação de um parecer da Consultoria Geral da República pelo Presidente da República e sua publicação conferem caráter normativo ao parecer, vinculando os órgãos da administração pública à sua disciplina.

${ }_{225} \mathrm{O}$ parágrafo $3^{\circ}$ do art. 192 estabelecia que: "As taxas de juros reais, nelas incluídas comissões e quaisquer outras remunerações direta ou indiretamente referidas à concessão de crédito, não poderão ser superiores a doze por cento ao ano; a cobrança acima deste limite será conceituada como crime de usura, punido em todas as suas modalidades, nos termos que a lei determinar."

${ }_{226}$ Interessante observar para compreensão do ambiente da época acontecimento quase anedótico relatado pelo autor do Parecer SR-70, Saulo Ramos, em artigo entitulado "FHC, juros e restaurante", publicado na Folha de São Paulo, em 03 de outubro de 1998, disponível [on-line] in http://www1.folha.uol.com.br/fsp/opiniao/fz2603200309.htm. Extrai-se desse artigo o seguinte trecho:

"Publicado o parecer, as instituições financeiras tranquilizaram-se. O mercado estava salvo. D. Sebastião não voltaria nunca mais. Por acaso, dias depois, hora do almoço, em um dos restaurantes de Brasília, encontrei-me com Fernando Henrique Cardoso, sempre simpático, mas disparou contra mim:

- Você pensa poder paralisar a vigência da Constituição com um simples parecer?

- Penso e já está paralisada nesse ponto.”
} 
outros $^{227}$. Num concerto entre BCB, Ministério da Fazenda e Presidência da República, decidiu-se negar aplicabilidade à limitação constitucional, restabelecendo-se a competência das autoridades monetárias para o controle da taxa de juros básica na implementação da política monetária (autonomia de meios). ${ }^{228}$

O parecer redigido por Saulo Ramos argumentou que o parágrafo $3^{\circ}$ do art. 192 constituiria uma norma de integração, “a reclamar, em caráter necessário, a mediação legislativa concretizadora do comando nela positivado" ${ }^{229}$, no caso, uma lei complementar, que por disposição do caput do art. 192, deveria disciplinar o Sistema Financeiro como um todo, a partir dos preceitos que aquele dispositivo constitucional ensejava, inclusive a limitação do parágrafo $3^{\text {o230 }^{23}}$.

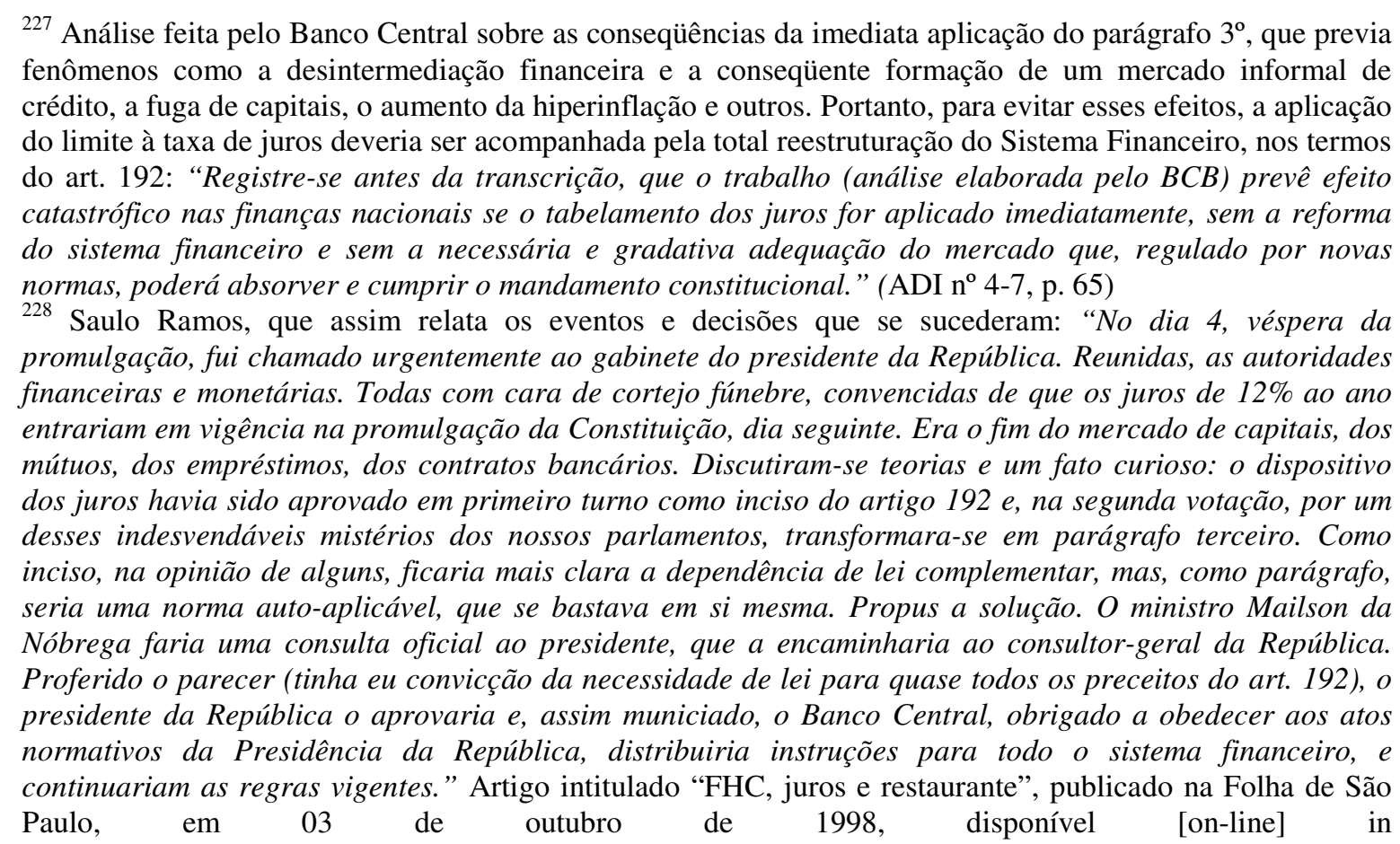
Paulo, em $03 \quad$ de outubro de
http://www1.folha.uol.com.br/fsp/opiniao/fz2603200309.htm.

${ }_{229}^{229}$ ADI no 4-7, p. 75. Esclareça-se que o Parecer SR-70 é integralmente transcrito no Relatório.

${ }^{230} \mathrm{O}$ parecer apresenta três argumentos principais. A primeira justificativa apresentada pelo parecer diz respeito à subordinação do disposto no parágrafo ao caput do artigo, que determinava a edição de lei complementar para a regulamentação do dispositivo constitucional. Segundo o parecer, o artigo deveria ser analisado em seu todo, sendo impreciso aplicar um de seus dispositivos enquanto os demais pendiam de regulamentação. Além disso, mesmo que se considere que o disposto em um parágrafo excetua o caput ou a ele não se subordina, o $§ 3^{\circ}$ figurava como o inciso IX do art. 192, tendo sido transformado em parágrafo pela Comissão de Redação. Assim, a vontade da Assembléia Constituinte, ao aprovar o dispositivo como inciso do artigo, seria submetê-lo à regulamentação por lei complementar. Outro argumento diz respeito à indefinição do que seriam juros reais. A Constituição não teria especificado o significado de juros reais, o que tornaria impossível aplicar o parágrafo 3. Por fim, há ainda um argumento evidentemente extra-jurídico: análise feita pelo Banco Central demonstraria alegadas consequências catastróficas sobre a economia diante da imediata aplicação do parágrafo $3^{\circ}$. 
Tendo diante de si a discussão acerca das alegadas conseqüências catastróficas do limite dos juros conforme estabelecido na Constituição, o STF confirmou a decisão do Poder Executivo de frear a aplicação dessa limitação, consolidando, mediatamente, os poderes do CMN e do BCB para a regulação dos juros. A decisão do STF neste caso se distingue por ser fundamentada estritamente em argumentos de ordem jurídico-formal, sem qualquer recurso a argumentos de ordem extra-jurídica pautados numa lógica consequencialista, preconizados pelo Parecer SR-70 e pelo $\mathrm{BCB}^{231}$. A fundamentação dos ministros que compuseram a apertada maioria de $6 \times 4$ compreendia $^{232}$, em síntese: (i) o artigo constitui um todo, devendo o parágrafo seguir o mandamento do caput, a não ser que o excepcione de modo expresso, o que não se verificaria na hipótese analisada. Assim, a aplicação do parágrafo $3^{\circ}$ dependeria de sua regulamentação por lei complementar, seguindo o caput do artigo 192; e (ii) não há caracterização do que seriam juros reais, o que deveria então ser feito em lei, propiciando o cálculo dos juros cobrados pelas instituições financeiras e sua subsunção ou não ao mandamento constitucional ${ }^{233}$.

Na prática, a decisão manteve a livre negociação dos juros no mercado, influenciado por decisões de política monetária, no âmbito macroeconômico, advindas do CMN e do BCB. Além disso, o STF não negou que o Poder Legislativo pudesse regulamentar a disciplina dos juros, no entanto, impôs uma série de condições e limitações à essa atividade e, na prática, devolveu às autoridades monetárias a autonomia de meios.

\footnotetext{
231 A preocupação em ater-se a uma pretensa racionalidade estritamente jurídica evidencia-se no seguinte excerto do voto do Ministro Célio Borja: "Desde que aqui estou, tenho procurado guardar-me de quaisquer considerações que não sejam estritamente jurídicas.” (ADI n 4-7, p. 232).

${ }^{232}$ Integraram a maioria os Ministros Sidney Sanches, relator do processo, Celso de Mello, Célio Borja, Octavio Gallotti, Aldir Passarinho e Moreira Alves.

${ }^{233}$ Os Ministros que se posicionaram pela declaração da inconstitucionalidade do parecer analisado, defenderam, a partir das lições de Ruy Barbosa, a eficácia plena do parágrafo $3^{\circ}$, pois os dispositivos que expressam proibições seriam em regra self-executing, conferindo um direito àqueles que operam no Sistema Financeiro, ao qual se contrapõe uma obrigação das instituições financeiras. Além disso, a referência a um conceito jurídico indeterminado como juros reais não significaria a inaplicabilidade da norma, mas sim a necessidade de concretização do conceito por meio da interpretação na atividade jurisdicional. Observa-se que os votos pelo provimento da ADI utilizaram-se em muitos momentos de argumentos que extravasam os limites de uma argumentação jurídico-formal, incorporando elementos econômicos e sociais (de ordem extrajurídica). Por fim, resta ressaltar a inclusão pelo Nesse sentido, o Ministro Carlos afirma expressamente considerar em sua análise "que as taxas de juros que estão sendo praticadas, hoje, no Brasil, são taxas que nenhum empresário é capaz de suportar. Nós sabemos que o fenômeno que se denomina, pitorescamente, de "ciranda financeira", é que é a tônica, hoje, do mercado financeiro, engordando os lucros dos que emprestam dinheiro e empobrecendo a força do trabalho e do capital produtivo. Tudo isso eu devo considerar e considero, Senhor Presidente, quando sou chamado, como juiz da Corte Constitucional, a dizer o que é a Constituição.” (ADI no 4-7, p. 173).
} 
Esse acórdão consolidou a concepção de que o STF entendeu ser necessário que o Sistema Financeiro fosse regulado por uma lei complementar única, por determinação do art. 192 da Constituição Federal. Essa crença transformou-se em uma espécie de mito, influenciando os casos relativos ao Sistema Financeiro Nacional que se seguiram. A despeito de essa tese não se sustentar em face da redação do caput e da análise do julgamento do STF na ADI $n^{\circ} 4^{234}$, o mito da lei complementar única arraigou-se entre as autoridades de regulação financeira e os agentes financeiros, que proclamavam a necessidade de que apenas uma lei complementar regulamentasse toda a matéria financeira.

Esse rígido raciocínio formal estabelecido pelo STF não apenas incrementou o ônus argumentativo nos casos a seguir analisados ao criar um precedente sempre invocado, como dificultou sobremaneira a atividade legislativa do Congresso Nacional, já que os custos políticos de se regulamentar toda a atividade do Sistema Financeiro Nacional de uma só vez eram quase insustentáveis. Note-se, nesse sentido, que ao alterar o art. 192 da Constituição por meio da Emenda Constitucional no 40, de 2003, o Congresso Nacional referiu-se expressamente a "leis complementares".

\section{Casos Proer e FGC}

A decisão do STF na ADI $n^{\circ} 4$ exaltou o raciocínio legal-racional como modo de legitimação da decisão do Poder Executivo. Entretanto, a racionalidade legal-racional ia de encontro às políticas do Poder Executivo na crise bancária vivenciada pelo país em meados da década de 1990, que exigiu maior intervenção das autoridades monetárias brasileiras tendo em vista a quebra de algumas instituições e a necessidade de liquidez gerada no sistema.

\footnotetext{
${ }^{234}$ Este entendimento de que uma só lei complementar deveria regular todo o Sistema Financeiro não é facilmente encontrado na decisão. Conforme apontam Virgílio Afonso da Silva e Jean Paul Cabral Veiga da Rocha, a tese da lei complementar única origina-se do item 6 da ementa da ADI $n^{\circ} 4$, que se referia ao "tratamento global" do Sistema Financeiro Nacional em futura lei complementar que observaria todas as normas do art. 192 da Constituição Federal. Entretanto, essa tese não se sustenta, conforme apontam os mesmo autores, em face da redação do caput e da análise do julgamento do STF na ADI no 4. Nesse sentido, ver A regulamentação do Sistema Financeiro Nacional: o art. 192 e o mito da lei complementar única, in Revista de Direito Mercantil 127, pp. 82-84.
} 
Em meio a essa crise, foi lançado o Programa de Estímulo à Reestruturação e Fortalecimento do Sistema Financeiro Nacional (Proer), criado pela Resolução $\mathrm{n}^{\circ} 2.208$ do $\mathrm{CMN}$, que ampliava o poder de fiscalização e intervenção do $\mathrm{CMN}$ e do $\mathrm{BCB}$, atribuindolhes uma série de ações que poderiam ser adotadas com o intuito de se evitar uma crise bancária.

Em 13 de novembro de 1995, ação direta de inconstitucionalidade com pedido de medida liminar contra a Medida Provisória $\mathrm{n}^{\circ} 1.179$, que regulava o Proer, foi ajuizada pelo Partido dos Trabalhadores (ADI $\mathrm{n}^{\circ}$ 1.376-9, conhecida como caso "Proer"). A demanda fundamentava-se em alegada inconstitucionalidade da medida provisória por legislar sobre matéria reservada pelo artigo 192 da Constituição Federal à lei complementar. A ADI n 4-7 era o precedente que embasava essa argumentação.

Foi negado provimento ao pedido de liminar por se considerar que não havia sido violada a reserva de lei complementar pela atuação do Presidente da República por meio de medida provisória. Isso porque a medida provisória analisada não inovava no campo reservado à lei complementar pelo art. 192 da CF. Segundo o Relator, Ministro Ilmar Galvão, a Lei $n^{\circ}$ 4.595/64, reconhecida como recepcionada pela Constituição de 1988 como lei complementar, atribuía ao CMN a competência para "zelar pela liquidez e solvência das instituições financeiras" (art. $2^{\circ}$, VI). Portanto a medida provisória impugnada, por simplesmente regulamentar a resolução do $\mathrm{CMN}$, não seria inconstitucional.

Pode-se extrair do voto do relator, acompanhado por uma série de Ministros, que: (i) o STF reconheceu a competência normativa do CMN para regular o Sistema Financeiro Nacional, que neste caso excedia inclusive à do próprio Presidente da República; e (ii) o STF admitiu que uma medida provisória, que está no mesmo nível hierárquico de uma lei ordinária, simplesmente regulamentasse uma resolução do $\mathrm{CMN}$, que era competente para inovar juridicamente.

Observa-se a subversão da lógica jurídico-formal imprimida na ADI $\mathrm{n}^{\circ}$ 4-7 em função do contexto econômico e de governabilidade, o que é evidenciado pela contraposição dos votos dos Ministro Maurício Corrêa - cuja lógica é eminentemente 
consequencialista - da exposição do Ministro Marco Aurélio, que ressalta a racionalidade legal-racional do direito em face da lógica da governabilidade:

Ministro Maurício Corrêa - "Sr. Presidente, essas medidas, na verdade, foram tomadas em face do momento econômico-financeiro por que passa o país. O paradigma foi o fenômeno ocorrido na Venezuela. Quando lá estive, na época da quebra do Banco Latino, pude verificar que foi desencadeada uma total desorganização em seu sistema financeiro. Apenas citei esse fato para ressaltar a real necessidade da adoção dessas medidas pelo Governo brasileiro. Desse modo, também não vejo nenhuma inconstitucionalidade. Por isso, acompanho o eminente Relator, indeferindo a media cautelar."${ }^{, 235}$

Ministro Marco Aurélio - "Por isso, peço vênia ao nobre Relator para, potencializando, sim, a Carta Política da República, no que representa segurança para toda a sociedade e não uma política governamental momentânea, deferir a liminar pleiteada"236

Ainda no âmbito do Proer, as resoluções do CMN de números 2.197 e 2.211, ambas de 1995, instituíram o Fundo Garantidor de Créditos (FGC), um mecanismo de regulação sistêmica denominado seguro de depósito ${ }^{237}$. Essa medida procurava recuperar a confiança que o investidor depositava na instituição financeira onde possuía aplicações, evitando assim possíveis corridas bancárias, que teriam efeitos nefastos sobre os sistemas monetário e econômico.

Essas resoluções foram diretamente questionadas pelo Partido dos Trabalhadores (ADI n 1.398-0; caso "FGC") com base essencialmente na alegada necessidade de lei complementar para a criação de fundo ou seguro para a garantia de créditos, aplicações e depósitos, com o objetivo de proteger a economia popular, conforme determinaria o caput do art. 192 e seu inciso VI (atualmente extinto) da Constituição Federal de $1988^{238}$.

\footnotetext{
${ }^{235}$ ADI no $1.376-9$, p. 25.

${ }^{236}$ ADI no $1.376-9$, p. 27.

${ }^{237} \mathrm{O}$ seguro de depósito funciona como uma garantia aos correntistas de um banco, à medida que assegura o pagamento de parte ou do total dos depósitos feitos em um determinado banco. No caso do FGC, o fundo constituído visava a garantir o crédito dos depositantes, estabelecido o teto de $\mathrm{R} \$ 20$ mil (vinte mil reais) por titular, em face de instituições financeiras participantes do fundo e que estivessem sujeitas à intervenção, liquidação extrajudicial ou falência, ou de instituições reconhecidas como insolventes pelo Banco Central mesmo que não estivessem sujeitas a esses regimes.

${ }^{238}$ Segundo a petição inicial, a inconstitucionalidade se originaria também da violação do art. 167, incisos VIII e IX, que proibiam, respectivamente, a utilização de recursos dos orçamentos fiscais para suprir necessidades ou déficits de empresas, fundações ou fundos sem autorização legislativa específica, e instituição de fundos de qualquer natureza sem autorização legislativa. Por fim, outra inconstitucionalidade residiria na extinção do Fundo de Garantia de Depósitos e Letras Imobiliárias (FGDLI) e da Reserva para a Promoção da Estabilidade da Moeda e do Cheque (RECHEQUE), transferindo os recursos públicos dos quais se constituíam para um fundo privado.
} 
Em sede de cognição sumária para análise de pedido liminar, o relator Ministro Francisco Rezek reconhece a existência do bom direito para a concessão da liminar, dada a necessidade de lei complementar para regular o sistema financeiro, inclusive para a criação de fundo ou seguro para a proteção da economia popular. Contudo, Rezek admite a configuração do periculum in mora somente no que concerne à utilização de recursos públicos na composição de um fundo privado. Nesse sentido, vota no sentido de conceder a liminar apenas para suspender a eficácia das resoluções quanto à utilização de recursos públicos na formação do FGC. Maurício Corrêa define o voto do Relator como o “caminho mais adequado ao deferir o possível"239.

Contrariando a lógica de seu voto no caso anterior, em que rejeitou que alusões à governabilidade e medidas urgentes pudessem exceder os limites impostos pela Constituição Federal, o Ministro Marco Aurélio decidiu pela lógica da governabilidade. A despeito de reconhecer a inconstitucionalidade das resoluções, enfatiza que os efeitos de sua decisão poderiam reverberar de modo indesejável, o que o leva a restringir os limites da liminar, nos termos do voto do Relator:

\begin{abstract}
"Senhor Presidente, creio que todos nós estamos de acordo quanto à plausibilidade jurídica do pedido, no seu todo. Costumo dizer que as coisas se complicam sempre quando há falha em atividade desenvolvida por determinada instituição. Refiro-me ao Congresso Nacional no que, passados oito anos, ainda não editou a lei complementar de que cogita o artigo 192 da Carta Federal. (...) Senhor Presidente, não fosse a repercussão do deferimento de uma liminar em maior extensão, considerados principalmente os pequenos investidores, os pequenos correntistas, não teria a menor dúvida em atuar no campo pedagógico, sinalizando ao autor do ato atacado que ele também deve obediência à Lei Maior, à Constituição Federal. Sensibiliza-me, contudo, o que foi dito relativamente à necessidade de manter-se, com eficácia, parte do diploma atacado visando a proteger justamente esses pequenos investidores. Assim, projeto o exame do vício formal para o julgamento da ação direta de inconstitucionalidade." 240
\end{abstract}

\footnotetext{
${ }^{239}$ Maurício Corrêa assim se justifica: "E o faz bem, tendo-se em vista que as medidas preconizadas nas normas questionadas, objeto desses atos do Banco Central do Brasil, visam exatamente a proteção do pequeno poupador. Já, pois, superposta a questão superficial, conveniência social de alta relevância, que pelo seu próprio conteúdo, indica seja preservado o princípio a que visaram as respectivas Resoluções." (ADI no $1.398-0$, p. 28).

${ }^{240}$ ADI n ${ }^{\circ} 1.398-0$, pp. 29 e s.
} 
Embora houvesse alegações consistentes de vícios formais, o STF confirmou as decisões do Poder Executivo nesses dois casos, pautado essencialmente por argumentos de governabilidade. Nesses casos não houve julgamento de mérito das ações, pois após o julgamento do pedido cautelar, os processos permaneceram sem andamento até que perdessem objeto (em função da alteração na redação do artigo 192) e fossem por consequiência arquivados.

Possível dizer que o STF “decidiu não decidir”, ou seja, esclarece ser a norma inconstitucional, mas adia essa declaração para o julgamento de mérito, que termina por não ocorrer. Essa estratégia teria permitido ao STF evitar a formalização em sentenças de mérito de decisões contraditórias nesses casos, impedindo assim a formação de um precedente no sentido de se permitir a inconstitucionalidade em contextos de crise de governabilidade $^{241}$.

Em função da questão da estabilidade, traduzida numa crise de governabilidade, no caso Proer, há a confirmação da independência de meios das autoridades monetárias, que teriam poderes mais amplos que o próprio Congresso Nacional ou a Presidência da República para regulamentar a questão por meio de lei ordinária ou medida provisória. Por sua vez, no caso FGC, argumentos substantivos quanto à governabilidade e complexidade das regulamentações ampliaram a autonomia de meios das autoridades monetárias, sendo a reserva de lei complementar flexibilizada em favor da alegada capacidade técnica e dinamismo dessas instituições.

$A D I n^{\circ} 2.591-1$

Em 26 de dezembro de 2001, a Confederação Nacional do Sistema Financeiro (CONSIF) propôs ação direta de inconstitucionalidade perante o STF, pretendendo a declaração da inconstitucionalidade da expressão "inclusive as de natureza bancária, financeira, de crédito e securitária”, que integra o art. $3^{\circ}, \S 2^{\circ}$, da Lei n 8.078/90 (Código

\footnotetext{
${ }^{241}$ Jean Paul Cabral Veiga da Rocha, A capacidade normativa de conjuntura no Direito Econômico: o déficit democrático da regulação financeira, pp. 130 e s.
} 
de Defesa do Consumidor - $\mathrm{CDC})^{242}$, o que tornaria a disciplina do $\mathrm{CDC}$ não aplicável às instituições bancárias.

O CDC permite a revisão judicial de um contrato quando se torne excessivamente oneroso ao devedor (art. 51), sem garantir, como o Código Civil, o equilíbrio das prestações entre as partes. Dessa forma, a principal questão de fundo trazida pela CONSIF em meio a uma série de argumentos como a necessidade de lei complementar para regulação do sistema financeiro ou oposição entre e o CDC e a disciplina da Lei $\mathrm{n}^{\circ}$ 4.595/64, diz respeito à definição de quais os limites do Poder Judiciário para disciplina dos juros. Segundo argumento, a aplicação do CDC poderia levar a instituição financeira a receber quantia menor do que aquela necessária à remuneração dos recursos por ela captados, o que colocaria em risco o funcionamento do sistema.

O julgamento desta ação se deu em diversas sessões plenárias, tendo a primeira delas ocorrido em 17 de abril de 2002, sendo o julgamento concluído apenas em 2006, com a improcedência da ação. No entanto, a decisão da Corte não permite a extração de uma precisa ratio decidendi sobre a questão dos juros praticados por instituições financeiras e a atuação do Poder Judiciário baseado no CDC. A leitura do acórdão da ação direta de inconstitucionalidade e dos embargos de declaração posteriormente opostos não esclarece com exatidão essa questão.

Desse confuso contexto, pode-se extrair, não sem alguma incerteza, que a maioria dos Ministros atribui a determinação dos juros a uma decisão de política monetária, que deve ocorrer ponderando o âmbito macroeconômico, sendo que a disciplina do CDC não interferiria sobre essa regulamentação. Dessa forma, a atuação do Poder Judiciário deveria ser restrita à coibição de abusos contratuais. Entretanto, os limites e a disciplina da atuação do Poder Judiciário não está clara. Não se definiu, por exemplo, se os abusos contratuais seriam coibidos com base no CDC ou nos dispositivos do Código Civil. A obscuridade e

\footnotetext{
${ }^{242}$ O Poder Judiciário discutia, desde a promulgação do CDC, a revisão da correção monetária e dos juros estipulados em contratos entre pessoas físicas ou pequenas empresas e instituições financeiras, em face da alegação de práticas abusivas por essas instituições no estabelecimento das taxas de juros aplicáveis sobre as obrigações contratuais. As instituições financeiras, entretanto, questionavam a aplicação do Código de Defesa do Consumidor a relações dessa ordem, pois teria o Sistema Financeiro peculiaridades e disciplina própria que afastariam o regramento do CDC das relações nesse âmbito. A presença contínua dessa divergência no âmbito do Poder Judiciário brasileiro teve como consequiência a edição da Súmula no 297 pelo Superior Tribunal de Justiça, em 12 de maio de 2004, reconhecendo a aplicação do CDC às instituições financeiras.
} 
confusão dos votos poderá levar a diversas decisões judiciais contraditórias em esferas inferiores, a despeito de se revestirem da prerrogativa de utilizar um precedente do $\mathrm{STF}^{243}$.

Vale notar que os Ministros Nelson Jobim e Eros Grau destacam o papel exclusivo do Poder Executivo na determinação da taxa de juros. A justificativa para tanto seria encontrada na necessidade de que a taxa de juros ponderasse o âmbito macroeconômico, integrando a política monetária do país.

A decisão da Corte parece consolidar a autonomia de meios das autoridades monetárias, limitando a possibilidade de revisão judicial de suas ações a partir de casos particulares. Além disso, novamente a complexidade técnica da formulação da política monetária e sua importância para o país são ressaltadas como razões para que ela se mantenha adstrita a uma burocracia técnica e especializada.

Em consonância com esse raciocínio, estaria excluída a possibilidade de regulamentação dos juros no âmbito microeconômico, pois: "essa poderosa capacidade de criação de riqueza abstrata não pode ficar sujeita a administração desde a perspectiva das relações microeconômicas, sob pena de comprometimento dos objetivos que o artigo 192 da Constituição visa a realizar, o desenvolvimento equilibrado do País e a satisfação do interesse da coletividade. ${ }^{, 244}$

Esse excerto do voto do Ministro Eros Grau reconhece que a política monetária e a regulamentação dos juros devem ter como fim o desenvolvimento equilibrado do país,

\footnotetext{
${ }^{243}$ A confusão aqui anunciada pode ser verificada pela contraposição da análise sobre o julgamento que fazem um dos advogados da CONSIF e uma das advogadas dos órgãos de defesa do consumidor que participaram do processo como "amicus curiae". Arnoldo Wald, advogado da CONSIF neste caso, assim enuncia o resultado do julgamento dos embargos: "Ficou, pois, claro que se mantinha a decisão na qual o STF não conhecia da ADI por entender, por maioria, que o CDC não tratava do custo e da remuneração do dinheiro nas operações financeiras. Em relação a essa afirmação, que continua constando do voto do Relator que reflete o entendimento da Corte, ficaram vencidos os Ministros Celso de Mello e Carlos Britto, que, embora mantendo as convicções pessoais, concordaram com a decisão dos embargos, que finalmente foi tomada por unanimidade." (A evolução do direito monetário na jurisprudência do Supremo Tribunal Federal, in Revista de Direito Público da Economia n. 18 (2007), p. 29).

Reportagem da Folha de São Paulo de 15 de dezembro de 2006 transcreve o entendimento de Cláudia Lima Marques, representante do Brasilcon e do Idec, acerca do julgamentos dos embargos de declaração: "Foi uma ampla vitória, pois o STF reafirmou que o CDC se aplica a todas as operações bancárias, inclusive os juros." Apud Silvana de Freitas, Código do Consumidor vale para juro, diz STF, publicado na Folha de São Paulo de 15 de dezembro de 2006, disponível [on line] in http://www1.folha.uol.com.br/fsp/dinheiro/fi1512200626.htm

${ }^{244}$ ADI n ${ }^{\circ} 2.591-1$, p. 187.
} 
corroborando a independência de meios e a existência de fins pré-estabelecidos no plano político.

Dessa forma, embora o STF identifique a vinculação das autoridades monetárias às metas estabelecidas, a força do discurso da complexidade das medidas de regulação monetária (evidentemente ligado à ideia de cientificização) e a superação da dogmática jurídica em diversos pontos, ainda que eminentemente formais, contribui para que a independência de meios se consolide e confere, em certa medida, maior liberdade para que as autoridades monetárias definam os fins a serem alcançados.

\subsubsection{A organização da burocracia: em prol da autonomia política e do cientificismo}

$A D I n^{\circ} 1.312-2$

Em 29 de junho de 1995 foi promulgada a Lei $n^{\circ}$ 9.069, de caráter ordinário e resultante de aprovação, pelo Congresso Nacional, da Medida Provisória no 542 e sucessivas reedições, que instituiu o Plano Real. No dia 04 de julho de 1995, o Partido dos Trabalhadores impetrou ação direta de inconstitucionalidade contra os artigos $8^{\circ}, 9^{\circ}, 10^{\circ} \mathrm{e}$ $11^{\circ}$ daquela lei, alegando contrariedade ao caput do artigo 192 da Constituição Federal, que exigiria que a matéria disciplinada pelos artigos questionados fosse disposta em lei complementar.

O principal aspecto de questionamento dizia respeito à organização do $\mathrm{CMN}$, que teve sua composição alterada, assim como os procedimentos deliberativos do órgão, alterando a Lei 4.594/64. Inicialmente, o CMN tinha em sua composição o Ministro da Fazenda, que presidia o Conselho, o Presidente do Banco do Brasil, o Presidente do BNDES e outros sete membros indicados pelo Presidente da República e aprovados pelo Senado, que deveriam ser escolhidos entre brasileiros de ilibada reputação e notória capacidade em assuntos econômico-financeiros, com mandato de sete anos, admitida a recondução. A Lei no 9.069/95 reduziu a composição do Conselho a apenas três membros, o Ministro da Fazenda, que permaneceu como seu presidente, o Ministro do Planejamento, 
que no regime anterior apenas podia participar das reuniões e, por fim, o Presidente do $\mathrm{BCB}$, que antes não participava do Conselho ${ }^{245}$.

Conforme aponta a Exposição de Motivos Interministerial $\mathrm{n}^{\mathrm{o}}$ 205/MF/SEPLAM/MJ/MTB/MPS/MS/SAF da Medida Provisória n 542, a mudança na composição do Conselho era necessária ao alcance da autonomia da autoridade monetária. "Com isso, assegura-se a compatibilidade das ações do Conselho com o objetivo de priorizar a gestão monetária e preservar o Real das pressões políticas e econômicas que possam por em risco a estabilidade do padrão monetário do país. „246

Extrai-se da exposição de motivos uma preocupação em garantir o estabelecimento de uma composição do CMN que priorizasse a estabilidade monetária como sua principal meta, o que reverberaria sobre os instrumentos de ação. Dessa forma, possível dizer que a reforma da instituição procurava institucionalizar a escolha pela estabilidade em detrimento dos demais objetivos da regulação monetária. ${ }^{247}$ Além disso, a reforma excluiu da gestão monetária uma série de participantes da sociedade civil, mantendo apenas membros da alta cúpula do governo. Essa reforma resultou, na prática, em maior autonomia política do $\mathrm{BCB}$, já que o $\mathrm{CMN}$ permanece pouco ativo nos últimos anos, com pouca ingerência dos Ministros da Fazenda e do Planejamento, num consenso do governo acerca da necessidade de garantir a autonomia política de fato do BCB.

Novamente diante do conflito entre a análise formal da constitucionalidade do dispositivo (baseado no procedente da $\mathrm{ADI}^{\circ}{ }^{4}$ ) e a propugnada relevância das alterações implantadas pelas disposições analisadas à nova política monetária do país, o STF negou

\footnotetext{
245 Quanto ao procedimento decisório, as deliberações permaneceram exigindo apenas maioria, sendo atribuído ao Presidente do $\mathrm{CMN}$, no novo regime, deliberar ad referendum do Conselho em casos de urgência e relevância.

${ }^{246}$ Petição inicial na ADI no $1.312-2$, p. 6.

247 A petição inicial do Partido dos Trabalhadores alegou ser autoritária a estrutura imposta pela lei questionada, pois afastaria setores expressivos da vida econômica, como os trabalhadores, instituições privadas e órgãos do executivo com maior potencial de controle social, da instância de discussão em que se dá o processo de formulação das políticas monetária, creditícia e cambial. Dessa forma, prevaleceria o interesse do governo e não da coletividade, desatendendo ao disposto no caput do art. 192 da Constituição Federal, que determina que o Sistema Financeiro promova o desenvolvimento equilibrado do país e sirva ao interesse coletivo. Ressalta ainda a inicial a questão do insulamento dos órgãos decisórios, que não se sujeitariam ao controle social sob a prerrogativa de se proporcionar autonomia à autoridade monetária: "Além disso, atenta contra o interesse público que decisões de enorme importância para o conjunto da sociedade sejam adotadas e implementadas sem o necessário controle social e transparência em virtude da alegada necessidade de "autonomia da autoridade monetária." ” (Petição Inicial na ADI no 1.312-2, p. 8).
} 
provimento ao pedido cautelar por unanimidade, assegurando maior autonomia política às autoridades monetárias. O Relator reconheceu em seu voto como plausível a alegação de que o CMN estaria inserido no inciso IV do art. 192 (o que exigiria Lei Complementar para sua disciplina). Contudo, considera que também seria possível afirmar que não se inclui o CMN nessa disciplina pois não houve sua menção expressa (o BCB, por exemplo, era mencionado expressamente) e a expressão "instituições financeiras públicas" não seria clara sobre sua abrangência. Dessa forma, não haveria fundamentos suficientes para, em fase de cognição sumária, deferir o pedido cautelar.

Assim como nos casos Proer e FGC, não houve julgamento de mérito, de modo a evitar a emergência de coisa julgada e de um possível precedente envolvendo a desconsideração de questões formais pelo STF. Isso porque após o julgamento do pedido cautelar, que ocorreu em 19 de outubro de 1995, o processo permaneceu durante quase seis anos com o Procurador-Geral da República, em função de pedido de vista deste, e depois mais alguns anos com o Relator, substituído pelo Ministro Joaquim Barbosa, que extinguiu o processo em 05 de agosto de 2004, alegando perda do objeto em razão da Emenda Constitucional $\mathrm{n}^{\circ}$ 40, que suprimiu todas as disposições do art. 192 da Constituição Federal, inclusive seu inciso IV.

ADI $3.289-5$

O Presidente Luís Inácio Lula da Silva editou a Medida Provisória $\mathrm{n}^{\circ} 207$ (em 2004), que continha como elemento principal a caracterização do Presidente do Banco Central como Ministro de Estado. Dessa forma, o BCB, que constituía uma autarquia federal segundo determinação do art. $8^{\circ}$ da Lei $n^{\circ} 4.595 / 64$, passaria a ser presidido por um Ministro de Estado.

A motivação para essa alteração no status jurídico do Presidente do BCB era atribuída pela imprensa a diversas acusações de sonegação fiscal e movimentação financeira irregular contra o atual Presidente do BCB, Henrique Meirelles. Nessa hipótese, o Presidente da República teria utilizado um instrumento emergencial como a Medida 
Provisória para "blindar" institucionalmente Henrique Meirelles, que passaria a ter prerrogativa de foro, de modo a ser julgado somente pelo $\mathrm{STF}^{248}$

A exposição de motivos, subscrita pelo então Ministro da Fazenda Antônio Palocci Filho, fundamenta a concessão de status de Ministro ao Presidente do BCB em face da complexidade e dos impactos econômicos de suas decisões, que exigiram maior autonomia e redução das esferas de questionamento:

\begin{abstract}
"No atual contexto de globalização da economia, com a participação cada vez mais efetiva da autoridade monetária do País no cenário nacional e internacional, o cargo de Presidente do Banco Central do Brasil assume, cada vez mais, relevância estratégica, tanto no cenário político quanto no plano institucional, em razão da complexidade e da relevância dos fatos da vida econômica.

(...) A relevância das matérias que integram a pauta de decisões do Presidente do Banco Central do Brasil, cujas atribuições compreendem, dentre outras medidas de notória complexidade, a formulação da política monetária do país e a intervenção no sistema financeiro nacional, na forma da legislação de regência, sugere a necessidade de conferir-lhe a condição de Ministros de Estado.",249
\end{abstract}

O Partido da Frente Liberal (PFL) e o Partido da Social Democracia Brasileira (PSDB) ingressaram com ações perante o STF questionando a constitucionalidade da

\footnotetext{
${ }^{248}$ Esse era o tom dos artigos publicados em jornais daquele período: "Na sexta-feira, quando decidiu que editaria essa MP, o presidente Luiz Inácio Lula da Silva já estava ciente de que o assunto seria mal recebido pelo Congresso Nacional e, antes de viajar, na segunda feira, deixou a medida assinada para não transferir ao vice-presidente José Alencar, uma tarefa tão delicada e constrangedora. Mesmo sabendo que o momento era totalmente inoportuno, dado que o presidente do BC vem sofrendo acusações de movimentação financeira irregular, embora sem provas, Lula decidiu atender a uma demanda do próprio Meirelles, acatada pelo ministro da Fazenda, Antonio Palocci. Diante da possibilidade de ver a situação do presidente do BC agravada por uma eventual decretação de prisão, por algum juiz de primeira instância, Lula optou por dar proteção institucional a Meirelles mesmo sob risco de desgaste. "Claudia Safatle, Governo enfrenta desgaste com Meirelles, publicado no jornal Valor Econômico em 18 de agosto de 2004, disponível [on line] in http://www.valoreconomico.com.br.

O editorial da Folha de São Paulo de 18 de agosto de 2004 não condena a concessão do status de Ministro ao Presidente do BCB, apontando a existência de práticas semelhantes em outros países, contudo critica sua concretização por Medida Provisória e o caráter casuístico da decisão: “É inábil a maquinação urdida no palácio do Planalto para blindar o presidente do Banco Central do Brasil, Henrique Meirelles, contra eventuais processos. Com efeito, é política e juridicamente injustificável a medida provisória $n^{\circ} 207$, que promove o banqueiro central à categoria de ministro de Estado, dando-lhe assim a prerrogativa de ser julgado pelo Supremo Tribunal Federal (STF), e não pelas instâncias ordinárias. Para começar, a manobra, escandalosamente casuística, sugere que o governo federal desconfie que o Ministério Público tenha razões para acionar Meirelles, o que não estava claro até aqui. A rigor, o artifício pode prejudicar o presidente do $B C$, pois, como ministro, ele fica sujeito a responder também pelo crime de responsabilidade, cuja tipificação dá margem a muita subjetividade." A Lei Meirelles, editorial publicado na Folha de São Paulo de 18 de agosto de 2004, disponível [on line] in htttp://www.folha.uol.com.br

249 Exposição de Motivos da Medida Provisória n ${ }^{\circ}$ 207, disponível [on line] in www.camara.gov.br/sileg/MostrarIntegra.asp?CodTeor=236947 [26-10-07].
} 
Media Provisória $n^{\circ}$ 207, constituindo as ações diretas de inconstitucionalidade números 3.289 e 3.290 , respectivamente ${ }^{250}$. O STF apreciou conjuntamente as duas ações, que, em síntese, fundamentavam a alegação de inconstitucionalidade (i) no afastamento da subordinação do BCB à orientação, coordenação e supervisão pelo Ministério da Fazenda, já que os Ministros não guardam relação hierárquica entre si; (ii) na violação do art. 192 da Constituição Federal, pois a organização e administração do BCB deveriam ser disciplinadas em lei complementar; (iii) na utilização de Medida Provisória para dispor sobre matéria de Direito Processual, ferindo o art. $62, \S 1^{\circ}$, inciso I, alínea "b", da Constituição Federal; e (iv) na equiparação do Presidente do BCB aos Ministros de Estado feriria também os arts. 52, inciso III, alínea “d”, e 84, incisos I e IX, da Constituição Federal por excluir da competência do Senado Federal a competência para aprovação do indivíduo indicado pelo Presidente da República para o cargo de Presidente do BCB, já que os Ministros de Estado são nomeados livremente pelo Presidente da República.

O Relator, Ministro Gilmar Ferreira Mendes, adotou o rito do art. 12 da Lei $n^{\circ}$ 9.868/99, submetendo o processo diretamente ao Tribunal para o julgamento definitivo da ação. A Sessão Plenária para julgamento das ações ocorreu em 05 de maio de 2005, quando a Medida Provisória no 207 já havia sido convertida em Lei pelo Congresso Nacional, que agregou ainda um dispositivo que estendia a competência especial por prerrogativa de função dos Ministros de Estado aos ex-presidentes do $\mathrm{BCB}$, no que concerne aos atos administrativos praticados no exercício dessa função.

Gilmar Ferreira Mendes ressalta que não consideraria abuso do poder de legislar a edição da medida com o único fim de atribuir prerrogativa de foro ao Presidente do BCB, de modo a afastá-lo de "uma avalanche de ações ajuizadas na primeira instância do Poder Judiciário", pois "Ora, estamos falando do Presidente do Banco Central! Todos sabemos o papel e a importância dessa autoridade na vida nacional. Todos sabemos que a escolha ou destituição de um Presidente do Banco Central possui, via de regra, uma repercussão maior que uma mudança na chefia de vários ministérios. ",251

\footnotetext{
${ }^{250}$ A semelhança no conteúdo das ações e seu julgamento conjunto pelo STF permitem sua análise como um caso único.

${ }^{251}$ ADI n $3.289-5$, p. 15.
} 
Uma vez que a maioria dos Ministros acompanhou o voto do relator, pode-se verificar nesse excerto que o Presidente do BCB é visto pelo STF como uma autoridade de extrema importância para a estrutura organizativa do país. Isso justificaria a necessidade de que lhe fosse concedida a prerrogativa de foro, que segundo o Relator, não se destina à proteção de um indivíduo mas sim da instituição por ele representada, não configurando, portanto, privilégio. O papel do BCB exige a proteção de seu Presidente de "perseguições" políticas consubstanciadas em ações judiciais propostas em primeira instância, o que configuraria, segundo o Ministro uma "tática de guerrilha" adotada por alguns setores para defender seus próprios interesses. ${ }^{252}$

A alegação de ofensa ao $\S 9^{\circ}$ do art. 62 da Constituição Federal, que exige que as medidas provisórias sejam examinadas por uma Comissão Mista de Senadores e Deputados antes de serem apreciadas pelo plenário das casas do Congresso Nacional, foi rejeitada pelo Relator. Interessante observar que o Ministro reconheceu a existência do vício formal, que seria suficiente à declaração da inconstitucionalidade. mas considerou inexigível essa declaração por observar que a Emenda Constitucional no 32 vigia há pouco tempo e que houve tentativas do Congresso em instalar as Comissões.

O Relator também nega que a norma apreciada afaste o BCB da subordinação ao Ministério da Fazenda, pois a competência do Ministério e do BCB se manteriam inalteradas, estando disciplinadas constitucionalmente. O Ministro Joaquim Barbosa, que votou no mesmo sentido do Relator explica que não há uma relação de subordinação entre o BCB e o Ministério da Fazenda, mas sim de vinculação, o que significa uma supervisão pelo órgão da Administração Direta do cumprimento das metas pelo outro órgão, sem que exista por isso uma relação hierárquica.

Quanto à possibilidade aventada pelos requerentes de que a medida feriria a separação de poderes ao extinguir a competência do Senado Federal para aprovar o nome indicado pelo Presidente da República ao cargo de Presidente do BCB, o Relator

\footnotetext{
${ }^{252}$ Não me parece difícil justificar a relevância e urgência de uma medida provisória que resulta na garantia de prerrogativa de foro para o Presidente do Banco Central quando a mesma prerrogativa é conferida para qualquer Ministro de Estado. E sabemos que há ministérios com um papel político que, a despeito de sua importância, não se equiparam ao Banco Central. Talvez por isso a nossa história registre tantos episódios de perseguição política ao Presidente do Banco Central e até aos diretores daquela instituição, por meio de ações judiciais ajuizadas em primeira instância.” ADI nº 3.289-5, p. 20.
} 
considerou que essa competência continua existindo, pois constituiria o Presidente do BCB um Ministro de Estado com procedimento de nomeação específico, nos termos do art. 52, III, “d”, da Constituição Federal. Ressalta o Ministro a existência de situação análoga quanto ao Advogado-Geral da União, que também possui status de Ministro e apresenta outros requisitos de nomeação além daqueles exigidos para a ocupação dos demais Ministérios.

A alegação de reserva lei complementar para a regulamentação do Sistema Financeiro, nos termos do art. 192 da Constituição Federal, tem sido o denominador comum de todos os casos aqui analisados. A análise do Relator sobre essa questão subverte a lógica de seu voto, que procurava demonstrar a importância da medida provisória ao exercício das funções de Presidente do $\mathrm{BCB}$, que seriam de extrema relevância à "vida nacional". Pode-se observar que a questão foi tratada como meramente administrativa, recorrendo a precedente da Corte sobre a desnecessidade de lei complementar para disciplinar questões relativas ao quadro de funcionários da instituição (ADI $n^{\circ} 449$ ). Portanto, a despeito de todo o discurso do Relator no sentido de exaltar o papel do Presidente do BCB e a necessidade de livrá-lo de pressão para que possa exercer suas funções dentro do Sistema Financeiro, equipara o Presidente aos demais funcionários do banco, inclusive quanto a suas atribuições, já que não influenciariam, nesse sentido a estrutura do Sistema Financeiro.

A necessidade de Lei Complementar foi afirmada apenas pelo Ministro Velloso, que reconheceu os impactos da alteração da qualificação do Presidente do BCB sobre o próprio Sistema Financeiro ${ }^{253}$. Cumpre observar que os demais Ministros apreciaram a alegação de necessidade de Lei Complementar com base no art. 192 como algo secundário, que mereceria uma análise subsidiária, pois não guardaria grande relevância ${ }^{254}$.

Conclui-se então que a iniciativa do Presidente da República posteriormente confirmada pelo Congresso em conferir status de Ministro ao Presidente do BCB, foi

\footnotetext{
${ }^{253} \mathrm{Um}$ interessante debate entre os Ministros foi travado neste ponto:

"O Sr. Ministro Carlos Velloso - Mas é a Constituição que exige lei complementar para certas matérias.

O Sr. Ministro Gilmar Mendes (Relator) - Não para os efeitos de definição do cargo.

O Sr. Ministro Carlos Velloso - Ora, o Presidente do Banco Central é o próprio sistema financeiro nacional." (grifos meus)

${ }^{254}$ Vale observar que os Ministros Marco Aurelio e Sepúlveda Pertence também votaram pela procedência da ação, por motivos atrelados à própria configuração jurídica do cargo de Presidente do BCB.
} 
também ratificada pelo STF, que exaltou a extrema relevância do Presidente do BCB na economia nacional e complexidade das matérias por ele tratadas para fundamentar a necessidade de limitação das vias de questionamento de sua ações. Como Ministro de Estado, o Presidente do BCB passaria a ter prerrogativa de foro, de modo a ser julgado somente pelo STF. Dessa forma, pode-se inferir que essa medida lhe conferiu maior autonomia política, reservando possíveis questionamentos a suas ações à análise pela Suprema Corte, uma via muito mais restrita de questionamento. Nesse contexto, acredito que tanto a exposição de motivos da Presidência da República para edição da medida provisória quanto a decisão do STF apontam para certo grau de cientificização das decisões do BCB, cuja complexidade técnica justificariam a ampliação da autonomia desse órgão. 


\section{CONCLUSÃO}

A manutenção da estabilidade monetária aliada ao discurso da cientificização em função da exaltada complexidade técnica das decisões foi relevante nas decisões do STF aqui analisadas, que terminaram por consolidar e até mesmo ampliar, em linha com os atos dos Poderes Executivo e Legislativo questionados perante a Corte, a autonomia do BCB na prática, contribuindo para que autonomia operacional do BCB se intensifique e, em certa medida, transforme-se em autonomia de metas.

De fato, a intensa crise inflacionária vivida pelo Brasil e o temor de que ela venha a se restabelecer, além de um alegado consenso em torno da ortodoxia econômica que preconiza a neutralidade da moeda no curto prazo, tornaram a estabilidade monetária um objetivo premente - e, possivelmente, exclusivo - para as autoridades monetárias brasileiras que, em razão de seu papel central nesse contexto, têm ganhado cada vez mais autonomia, por se acreditar que a "despolitização" das decisões sobre regulação monetária seriam fundamentais para a manutenção da estabilidade. A "despolitização" da autoridade monetária tem evoluído para um processo de "apolitização", em que suas decisões são vistas como ciência e, por isso, não sujeitas a questionamentos por políticos ou juízes.

Nesse sentido, a despeito do contexto econômico nacional ser marcado por intensa desigualdade regional e concentração do crédito bancário em determinadas regiões e, embora a Constituição Federal de 1988 e a Lei 4.595/64 tenham atribuído às autoridades monetárias um papel transformador, as autoridades monetárias brasileiras têm concentrado suas ações unicamente na manutenção da estabilidade de preços e higidez financeira, o que constituiria uma eleição de metas a partir de sólidas bases científicas. No entanto, essa escolha ignora as demais metas estabelecidas pelo ordenamento jurídico para a regulação monetária, sem que haja qualquer debate amplo e aberto sobre a eleição da estabilidade como prioridade.

Este trabalho procurou demonstrar que a atuação das autoridades monetárias brasileiras não pode confiar sem questionamentos nos pressupostos da ortodoxia econômica que se arroga o caráter de consenso entre teóricos e bancos centrais. A 
concepção segundo a qual as autoridades monetárias contribuem para o desenvolvimento do país unicamente mediante a garantia da estabilidade macroeconômica precisa ser repensada, especialmente em país em desenvolvimento como o Brasil, à luz (i) do amplo debate existente na teoria econômica em questionamento à ortodoxia, (ii) do contexto econômico e social do país, e (iii) do fato de que a regulação monetária integra a política econômica do Estado, devendo observar as escolhas políticas consubstanciadas em normas jurídicas.

Tratando especificamente a questão do desenvolvimento regional, foram analisados uma série de argumentos críticos à ortodoxia, procurando evidenciar que o sistema bancário tende à concentração do crédito nas regiões mais desenvolvidas, perpetuando e agravando o desenvolvimento regional desigual. Além disso, demonstrou-se que essa previsão teórica, na contramão do quanto pressupõe a ortodoxia, verifica-se me pesquisas empíricas realizadas no Brasil, país marcados por intenso desigualdade regional e onde o sistema bancário tende a contribuir para essa condição.

Nesse ponto, foi indicado que o Estado pode ter um papel fundamental para alterar a estrutura do mercado bancário e reduzir a assimetria regional. No caso brasileiro, esse papel é reconhecido pelo ordenamento jurídico, que encerra claras escolhas políticas no sentido de atribuir às autoridades monetárias e ao sistema financeiro papel central no processo de desenvolvimento do país, com especial ênfase à questão regional. Significa dizer que tanto a Constituição Federal quanto a Lei 4.595/64 não procuram apenas a preservação do status quo/estabilidade, mas colocam o sistema financeiro e as autoridades monetárias no centro do processo de alteração do status quo, exigindo políticas ativas de intervenção (a Constituição de 1988 seria assim verdadeira Constituição Econômica).

Este trabalho procurou demonstrar que essa atuação é especificamente necessária diante da preocupação constitucional com a redução das desigualdades regionais dado que, como visto acima, numa economia como a brasileira o livre jogo do mercado tende à concentração do crédito e intensificação das condições de desenvolvimento regional desigual. 
Os parâmetros aqui delineados devem integrar a análise da accoutability das autoridades monetárias no Brasil. É necessário trazer tais pontos ao debate público para que as autoridades monetárias sejam supervisionadas e cobradas a esse respeito. Contudo, o que se observa é a total ausência desse debate na esfera pública. Como observado, as autoridades monetárias ignoram a questão do desenvolvimento regional e não foram identificadas iniciativas no sentido de justificar seus atos, ou melhor, a inação a esse respeito. A atuação desses órgãos nos últimos anos revela verdadeira supressão ou modificação dos objetivos das autoridades monetárias no Brasil, que, mesmo cientes do mandato legal diverso, alçaram a estabilidade de preços e financeira a seus únicos objetivos, fundamentando essa verdadeira reforma institucional no alegado cientificismo de suas escolhas e ações. Por isso, é necessário destacar que as autoridades monetárias no Brasil não têm goal independence, o que exige que justifiquem suas ações tendo em vista as metas estabelecidas, evidenciando e fundamentando seus atos e escolhas a partir dos parâmetros definidos como objetivos por meio de regras jurídicas.

Este trabalho não defende a desconsideração da estabilidade de preços. Na verdade, essa é sem dúvida uma das metas centrais de atuação das autoridades monetárias, sendo expressamente prevista no art. $3^{\circ}$ da Lei $4.595 / 64$ e pelo exame do art. $154, \S 1^{\circ}$, da Constituição de 1988. No entanto, não se pode resumir a regulação monetária a esse ponto. A Constituição e a Lei estabeleceram outras metas que devem conviver com a meta da estabilidade. Portanto, a questão central não é a priorização da estabilidade de preços, mas sim a total desconsideração das demais metas (dentre elas o desenvolvimento regional).

Desde que justificada substantivamente, a eleição de prioridades dentre as diversas metas é sim possível. Todavia, as prioridades devem ser revistas constantemente e podem conviver com diversas ações relacionadas às outras metas. Assim, o tempo e a experiência indicarão caminhos e instrumentos para o desenvolvimento da convivência entre as diversas metas. Os instrumentos testados devem ter seus resultados expostos publicamente (a ideia de "learning by doing" é fundamental nesse processo), ampliando a accountability substantiva. 


\section{BIBLIOGRAFIA}

ADDISON, Tony; CORNI, Giovanni. Income Distribution Policies for Faster Poverty Reduction, WIDER Discussion Paper n. 93, UNU-WIDER, 2001.

ALESSANDRINI, Pietro; ZAZZARO, Alberto. A 'Possibilist' Approach to Local Financial Systems and Regional Development: the Italian Experience, in Ron Martin (org.), Money and the Space Economy, Wiley, 1999: 71-91.

ALEXANDRE, Michel; LIMA, Gilberto Tadeu; CANUTO, Otaviano. Determinantes das decisões locacionais da atividade financeira, in Nova Economia 16 (2006): 243-263

ALVES JR., Antonio José. Sistematização do debate sobre "Sistemas de Financiamento do Desenvolvimento", in Desenvolvimento em debate: novos rumos do desenvolvimento no mundo, Rio de Janeiro: BNDES, 2002.

AMADO, Adriana. A questão regional e o sistema financeiro: uma interpretação póskeynesiana, in Estudos Econômicos, v. 27, n.3 (1997): 417-440.

Disparate Regional Development in Brazil - A Monetary Production Approach, Aldershot: Ashgate.

Impactos regionais do processo de reestruturação bancária do início dos anos 1990, in CROCCO, Marco; JAYME JR. Frederico, Moeda e território: uma interpretação da dinâmica regional brasileira, Belo Horizonte: Autêntica, 2006: 147-168.

Moeda, financiamento, sistema financeiro e trajetórias de desenvolvimento regional desigual: a perspectiva pós-keynesiana, in Revista de Economia Política, vol 18, n. 1 (1998): 76-89.

ARESTIS, Philip; PAULA, Luiz Fernando de; FERRARI-FILHO, Fernando. A nova política monetária: uma análise do regime de metas de inflação no Brasil, in Economia e Sociedade v. 18, n. 1 (2009). 
BANCO CENTRAL DO BRASIL. Políticas de crédito no Brasil, 2004.

Relatório de Economia Bancária e Crédito, 2010

BARROSO, Luís Roberto. O direito constitucional e a efetividade de suas normas, 4 ed., Rio de Janeiro: Renovar, 2000.

BERCOVICI, Gilberto. Constituição econômica e desenvolvimento - uma leitura a partir da Constituição de 1988, São Paulo: Malheiros, 2005.

. Desigualdades regionais, estado e constituição, São Paulo: Max Limonad, 2003.

BERCOVICI, Gilberto; MASSONETO, Luís Fernando. A Constituição Dirigente invertida: a blindagem da constituição financeira e a agonia da Constituição Econômica, Separata do Boletim de Ciências Econômicas XLIX (2006).

BORGES, Florinda Figueiredo. Intervenção estatal na economia: o banco central e a execução das políticas monetária e creditícia, Dissertação de mestrado, Faculdade de Direito da Universidade de São Paulo, 2010.

CANOTILHO, José Joaquim Gomes. Constituição Dirigente e vinculação do legislador: contributo para a compreensão das normas constitucionais programáticas, 2. ed., Coimbra, 2001.

Direito Constitucional, 3. ed., Coimbra: Almedina.

CAPRIO, Gerard et. al (org.), The Future of State-Owned Financial Institutions, Washington: Brookings Institution, 2004.

CARPIE, Forrest; GOODHART, Charles; SHNADT, Norbert., The development of central banking, in CARPIE, Forrest et al, The future of central banking, Cambridge: University Press, 1994: 1-123 
CARVALHO, Fernando Cardim. A economia keynesiana e a moeda na economia moderna, in Macro Crocco e Frederico G. Jayme Jr., Moeda e território, Belo Horizonte: Autêntica, 2006: 29-38.

A independência do Banco Central e a disciplina monetária: observações céticas, in Revista de Economia Política, vol. 15, n.4 (1995): 134-141

Alta inflação e hiperinflação: uma visão pós-keynesiana, in Revista de Economia Política n. 10 (1990): 62-82.

O papel do Banco Central no processo de regulação financeira, in CAMPILONGO, Celso F.; ROCHA, Jean Paul C. Veiga da; MATTOS, Paulo T. Lessa (org.), Concorrência e Regulação no Sistema Financeiro, São Paulo: Max Limonad, 2002: 257-266.

Sobre a preferência pela liquidez dos bancos, in Luiz Fernando de Paul e José Luis Oreiro (org.), Sistema Financeiro - Uma análise do setor bancário brasileiro, Rio de Janeiro: Elsevier, 2007: 3-22.

CARVALHO, Fernando Cardim et. al, Economia Monetária e Financeira: teoria e política, 2. ed., Rio de Janeiro: Elsevier, 2007.

CAVALCANTE, Anderson Cavalcante; CROCCO, Marco; JAYME JR., Frederico G. Preferência pela liquidez, sistema bancário e disponibilidade de crédito regional, in CROCCO, Marco; JAYME JR. Frederico, Moeda e território: uma interpretação da dinâmica regional brasileira, Belo Horizonte: Autêntica, 2006: 295-316.

CAVALCANTE, Luiz Ricardo Mattos Teixeira. Sistema Financeiro no Brasil: aspectos regionais, disponível on-line in http://www.bnb.gov.br/

COMPARATO, Fabio Konder. A afirmação histórica dos direitos humanos, São Paulo: Saraiva, 1999. 
$O$ indispensável Direito Econômico, in Ensaios e Pareceres de Direito Empresarial, Rio de Janeiro: Forense, 1978.

CORRIGAN, Gerald. Are Banks Special?, Annual Report Essay, Federal Reserve Bank of Minneapolis, 1982, disponível on-line in http://www.minneapolisfed.org/pubs/ar/ar1982a.cfm.

CORTEZ, Tiago Machado. Moeda, estado e direito: o papel do estado na ordem monetária e seu controle, Tese de Doutorado apresentada à Faculdade de Direito da Universidade de São Paulo.

O conceito de risco sistêmico e suas implicações para a defesa da concorrência no mercado bancário, in CAMPILONGO, Celso F.; ROCHA, Jean Paul C. Veiga da; MATTOS, Paulo T. Lessa (org.), Concorrência e Regulação no Sistema Financeiro, São Paulo: Max Limonad, 2002: 311-333.

CROCCO, Marco; BARRA, Claudia. Moeda e espaço no Brasil: um estudo de áreas selecionadas, in Revista de Economia Politica vol. 24, n. 3 (2004): 386-403.

CROCCO, Marco; SANTOS, Fabiana; AMARAL, Pedro. The Spatial Structure of Financial Development in Brazil, UFMG/CEDEPLAR, Belo Horizonte, 2009.

CROCCO, Marco et. al. Desenvolvimento econômico, preferência pela liquidez e acesso bancário: um estudo de caso, UGMG/CEDEPLAR, Belo Horizonte, 2003.

CROCCO, Marco et. al. Polarização regional e sistema financeiro, in CROCCO, Marco; JAYME JR. Frederico, Moeda e território: uma interpretação da dinâmica regional brasileira, Belo Horizonte: Autêntica, 2006: 231-270.

CUKIERMAN, Alex; WEBB, Steven B.; NEYAPTI, Bilin. Measuring the Independence of Central Banks and its Effects on Policy Outcomes, in The World Bank Economic Review, vol. 6, n. 3 (1992): 353-398. 
DAGDEVIREN, Hulya; VAN DER HOEVEN, Rolph; WEEKS, John. Redistribution Does Matter, WIDER Discussion Paper n. 5, UNU-WIDER, 2002

DE CHIARA, José Tadeu. Moeda e Ordem Jurídica, Tese de Doutorado, Faculdade de Direito da USP, 1986.

DE BANDT, Olivier; HARTMANN, Philipp. Systemic Risk: a Survey, Working Paper n. 35, European Central Bank, 2000.

DOW, Sheila. Incorporating Money in Regional Economic Models, in Sheila Dow, Money and the Economic Process, Aldershot: Edward Elgar, 1993: 111-121.

Money and Regional Development, in Sheila Dow, Money and the Economic Process, Aldershot: Edward Elgar, 1993: 141-158.

. The Regional Composition of the Bank Multiplier Process, in Sheila Dow, Money and the Economic Process, Aldershot: Edward Elgar, 1993: 73-97.

The Stages of Banking Development and the Spatial Evolution of Financial Systems, in Ron Martin (org.), Money and the Space Economy, Wiley, 1999: 31-48.

The Treatment of Money in Regional Economics, in Sheila Dow, Money and the Economic Process, Aldershot: Edward Elgar, 1993: 98-110.

DOW, Sheila; RODRIGUEZ-FUENTES, Carlos Javier. Um "survey"da literatura de finanças regionais, in CROCCO, Marco; JAYME JR. Frederico, Moeda e território: uma interpretação da dinâmica regional brasileira, Belo Horizonte: Autêntica, 2006: 39-75.

DURAN, Camila Villard. A moldura juridical da política monetária - um estudo de caso, Tese de Doutorado, Faculdade de Direito da Universidade de São Paulo, 2012 
DURAN-FERREIRA, Camila. Direito e regulação econômica: o controle dos planos de estabilização monetária pelo Supremo Tribunal Federal - um enfoque empírico, Dissertação de Mestrado, Faculdade de Direito da Universidade de São Paulo, 2008.

ELSTER, Jon. Constitutional Courts and Central Banks: Suicide Prevention or Suicide Pact?, East European Constitutional Review, n. 3 (1994): 66-71.

EPSTEIN, Gerald. Central Banks as Agents of Economic Development, in Ha-Joon Chang (org.), Institutional Change and Economic Development, United Nation University Press, 2008: 95-114.

FABIANI, Emerson Ribeiro, Reformas institucionais do mercado de crédito bancário no Brasil (1999-2006): uma análise jus-sociológica, Tese de Doutorado, Universidade de São Paulo, 2009.

FARIA, José Eduardo. O Direito na economia globalizada, São Paulo: Malheiros, 2004.

FISCHER, Fischer. Central Bank Independence Revisited, in The American Economic Review, vol 85, n.2 (1995): 201-206.

Modern Approach to Central Banking, NBER Working Paper n. 5064, 1995.

FRAGA, Armínio. O papel do Banco Central no século 21, In Revista de Direito Bancário e do Mercado de Capitais, v.2, n.6 (1999): 21-23.

FREITAS, Ana Paula Gonçalves de; PAULA, Luis Fernando Rodrigues de. Concentração regional do crédito e consolidação bancária no Brasil: uma análise pós-real, in Revista EconomiA, vol. 11, n.1 (2010): 97-123.

FRIEDMAN, Milton. A theoretical framework for monetary analysis, in WALTERS, A. A. (org.), Money and Banking, Harmondsworth: Penguin, 1973. 
FRY, Maxwell J.; GOODHART, Charles; ALMEIDA, Alvaro. Central Banking in Developing Countries, London: Routledge, 1996.

FORGIONI, Paula A.. Análise econômica do Direito (AED): paranóia ou mistificação?, in Revista de Direito Mercantil, Industrial, Econômico e Financeiro 139 (2005): 242-256.

FURTADO, Celso. Criatividade e dependência na civilização industrial, Rio de Janeiro: Paz e Terra, 1978.

GRAU, Eros. A ordem econômica na Constituição de 1988, 9. ed, São Paulo: Malheiros, 2004.

GOODHART, Charles. Central Bank Independence, Special Paper 57, London: London School of Economics, 1993.

. Money, Information and Uncertainty, 2. ed., Cambridge: MIT, 1989.

. The Changing Role of Central Banks, LSE Financial Market Groups Paper Series 197, 2010.

The Evolution of Central Banks, Cambridge: MIT Press, 1988.

GOODHART, Charles et al., Financial Regulation: Why, How and Where Now?, Routledge, 1998.

HOLMES, Stephen Holmes; SUSTEIN, Cass R. The Cost of Rights - Why Liberty Depends on Taxes, New York: W. W. Norton.

IMBS, Jean; WACZIARG, Romain. Stages of Diversification, in American Economic Review 93 (2003): 63-86.

JÁCOME, Luis. Legal Central Bank Independence and Inflation in Latin America During the 1990s, IMF Working Paper, 2001. 
JACQUEMIN, Alexis; SCHRANS, Guy. Le droit économique, 3. ed., Paris: Universitaires de France, 1982.

KEYNES, John Maynard. Teoria geral do emprego, do juro e da moeda, 2.ed., São Paulo: Nova Cultural, 1985.

KYDLAND, Finn; PRESCOTT, Edward. Rules rather than discretion: the inconsistency of the optimal plan, in Journal of Political Economy 85 (1977): 473-492.

LA PORTA, Rafael et. al. Law and Finance, Working Paper 5661, Cambridge, Mass: National Burreau of Economics, 1996.

Legal Determinants of External Finance, in Journal of Finance 52 (1997): 11311150.

LA PORTA, Rafael; LÓPEZ-DE-SILANES, Florencio; SHLEIFER, Andrei. Government Ownership of Banks in Journal of Finance 57 (2002): 265-301.

LEIGH-PEMBERTON, Robert. The Case for Price Stability, in Bank of England Quarterly Bulletin 32 (1992): 441-448.

LEVINE, Ross. , Finance and Growth: Theory and Evidence, Working Paper n. 10766, National Bureau of Economic Research, disponível on-line in http://papers.ssrn.com/sol3/papers.cfm?abstract_id=592145.

Financial Development and Economic Growth - Views and Agenda, in Journal of Economic Literature vol. XXXV (1997): 688-726.

MALAN, Pedro. Verbete: Superintendência da Moeda e do Crédito (SUMOC), in Dicionário Histórico Bibliográfico Brasileiro do Centro de Pesquisa e Documentação de História Contemporânea do Brasil da Fundaçào Getúlio Vargas, disponível on-line in www.cpdoc.fgv.br. 
MARCUSSEN, Martin. Institutional Transformation? The Scientization of Central Banking as a Case Study, in Tom Christensen and Per Laegreid (org.), Autonomy and Regulation - Coping with Agencies in the Modern State, Edward Elgar, 2006: 81-105.

The Fifth Age of Central Banking in the Global Economy, Working Paper Frontiers of Regulation, 2006.

MARTIN, Ron. The New Geography of Money, in MARTIN, Ron (org.), Money and the Space Economy, Wiley, 1999: 3-28.

MENESES, Melissa; CROCCO, Marco; SANCHES, Elisângela; AMADO, Adriana. Sistema financeiro e desenvolvimento regional: notas exploratórias, in Luis Fernando de Paul e José Luís Oreiro (org.), Sistema financeiro - uma análise do setor bancário, Rio de Janeiro: Elsevier, 2007: 285-305.

MISHKIN, Frederic S. The Economics of Money, Banking and Financial Markets, 7. ed., Addison Wesley, 2004.

MODENESI, André de Melo. Política monetária no Brasil pós Plano Real (1995-2008): um breve retrospecto, in Economia \& Tecnologia 21 (2010).

MOREIRA, Vital. A ordem jurídica do capitalismo, Coimbra: Centelho, 1978. Economia e Constituição - para o conceito de Constituição Econômica, Separata do Boletim de Ciências Econômicas XVII (1974).

NUNES, António José Avelãs. Nota sobre a independência dos bancos centrais, in Revista de Direito Mercantil, Industrial, Econômico e Financeiro 103 (1996): 59-73.

PEREIRA JR. Ademir Antonio. Legitimidade e governabilidade na regulação do sistema financeiro - uma análise da jurisprudência do STF, in Revista Direito GV 8 (2009): 517538. 
- Legitimidade e governabilidade na regulação do sistema financeiro: crise inflacionária, reforma constitucional e estabilidade econômica na jurisprudência do STF, in COUTINHO, Diogo e VOJVODIC, Adriana. Jurisprudência Constitucional: como decide o STF?, São Paulo: Malheiros, 2009: 301-318.

O papel do STF na regulação do Sistema Financeiro Nacional, Monografia para conclusão da Escola de Formação da Sociedade Brasileira de Direito Público - SBDP, 2007, disponível in http://www.sbdp.org.br/ver_monografia.php?idMono=103.

PINHEIRO, Armando Castelar. Bancos públicos no Brasil: para onde ir?, in PINHEIRO, Armando Castelar; OLIVEIRA FILHO, Luiz C. Mercado de capitais e bancos públicos análise e experiências comparadas, Rio de Janeiro/São Paulo: Contra-Capa/ANBID, 2007: 159-264.

PORTEOUS, David. The Development of Financial Centres: Location, Information, Externalities and Path Dependence, in MARTIN, Ron (org.), Money and the Space Economy, Wiley, 1999: 95-114.

RAY, Debraj. Development Economics, Princeton: Princeton University, 1998.

ROCHA, Jean Paul Veiga da. A capacidade normativa de conjuntura no direito econômico: o déficit democrático da regulação financeira, Tese de Doutorado, Faculdade de Direito da Universidade de São Paulo, 2004.

Autonomia e accountability no sistema financeiro: notas para uma agenda de pesquisa jurídica, in Revista de Direito Público da Economia 33 (2011): 95-112.

RODRIK, Dani. Industrial Policy for Twenty-First Century, disponível on line in http://ksghome.harvard.edu/ drodrik/papers.html

SADDI, Jairo. O poder e o cofre - repensando o Banco Central, São Paulo: Textonovo, 1997. 
SCHUARTZ, Luis Fernando. Banco Central: questões jurídico-políticas na Constituição de 1988, in Revista de Direito Mercanti, Industrial, Econômico e Financeiro 93 (1994): $36-48$.

SCHUMPETER, Joseph A. Teoria do desenvolvimento econômico, Fundo de Cultura: Rio de Janeiro, 1961.

SEN, Amartya. Desenvolvimento como liberdade, São Paulo: Companhia das Letras, 2000.

Development: which way now?, In The Economic Journal, Vol. 93, No. 372 (1983).

SILVA, Fernanda Faria; CROCCO, Marco Aurélio; RODRIGUEZ-FUENTES, Carlos Javier. Limitações teóricas da literatura convencional sobre impactos regionais de política monetária, UFMG/CEDEPLAR, Belo Horizonte, 2010.

SILVA, José Afonso da. Aplicabilidade das normas constitucionais, 8. ed., São Paulo: Malheiros, 2012.

SILVA, Virgílio Afonso da. Direitos Fundamentais - conteúdo essencial, restrições e eficácia, 2. ed., São Paulo: Malheiros, 2010.

SILVA, Virgílio Afonso da; ROCHA, Jean Paul Cabral Veiga da. A regulamentação do Sistema Financeiro Nacional: o art. 192 e o mito da lei complementar única, in Revista de Direito Mercantil n. 127: 79-92.

SOLA, Lourdes; GARMAN, Christopher; MARQUES, Moise., Central Banking, Democratic Governance and Political Authority: the Case of Brazil in a Comparative Perspective, in Revista de Economia Politica, vol. 18, n. 2 (1998): 106-131. 
SORGATO, Lucas André Ajala; FERREIRA JUNIOR, Reynaldo Rubem; SANTOS, Patrícia Rocha dos. Concentração bancária e desigualdade regional: o caso do nordeste brasileiro, disponível on-line in http://www.bnb.gov.br/.

SOUZA, Washington Peluso Albino de. Direito Econômico, Saraiva, 1980.

STALLINGS, Barbara; STUDART, Rogerio. Finance for Development - Latin America in Comparative Perspective, Washington: Brookings, 2006.

STIGLER, George. The Goals of Economic Policy, in The Journal of Business vol. XXXI (1958): 176-196.

TORRES FILHO, Ernani Teixeira. Crédito direcionado e direcionamento de crédito: situação atual e perspectivas, in Revista do BNDES 25 (2006): 35-50.

TURCZYN, Sidnei. O Sistema Financeiro Nacional e a regulação bancária, São Paulo: Revista dos Tribunais, 2005.

VENÂNCIO FILHO, Alberto. A intervenção do Estado no domínio econômico - O Direito Público Econômico no Brasil, ed. fac-similar da de 1968, Rio de Janeiro: Renovar, 1998.

VIDIGAL, Geraldo Camargo. Direito Monetário, São Paulo: IBCB, 1995. Disciplina dos órgãos de direção monetária, Tese de Livre-Docência, Faculdade de Direito da USP, São Paulo, 1964.

VOLCKER, Paul A. The Triumph of Central Banking?, Washington: International Monetary Fund, 1990.

VOLCKER, Paul A.; MANCERA, Miguel; GODEAUX, Jean., Perspectives on the Role of a Central Bank, Washington: International Monetary Fund, 1991. 
WILKINSON, Richard; PICKETT, Kate. The Spirit Level - Why More Equal Societies Almost Always Do Better, Allen Lane, 2009.

WORLD BANK, Brazil Investment Climate Assesment N. 2 (2005).

ZARA, Thaís Marzola. Desenvolvimento financeiro, crescimento e desigualdade nos estados brasileiros, Dissertação de Mestrado, Faculdade de Economia, Administração e Contabilidade da Universidade de São Paulo, 2006. 